\title{
‡USGS
}

D.MS

National Water-Quality Assessment Program

\section{Trace Elements and Radon in Groundwater Across the United States, 1992-2003}

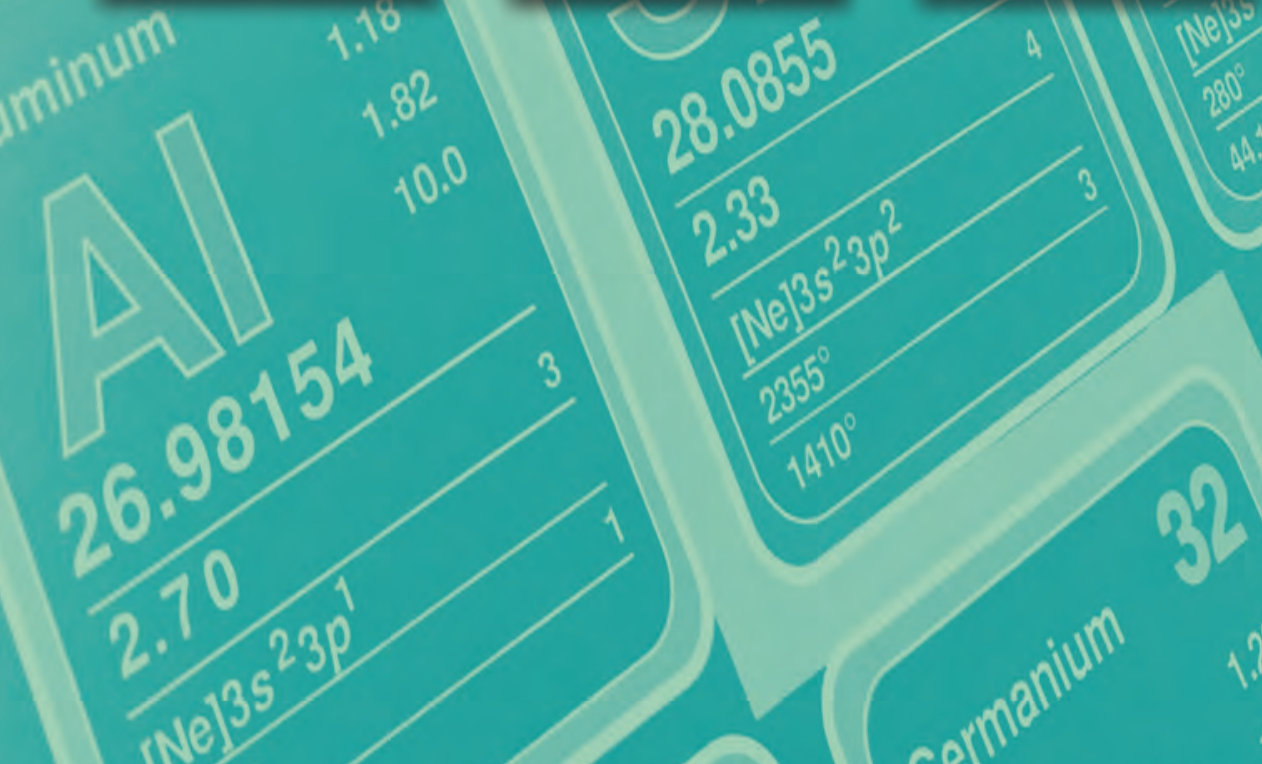

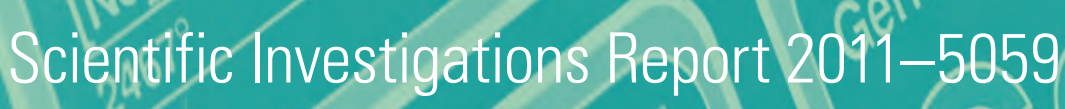

\section{Whes}

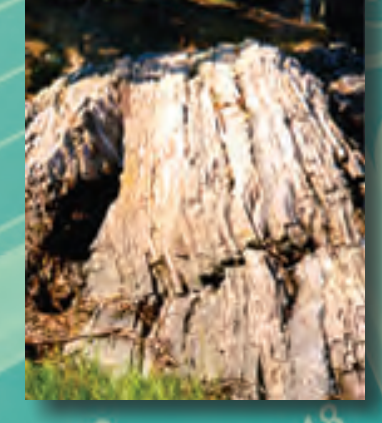

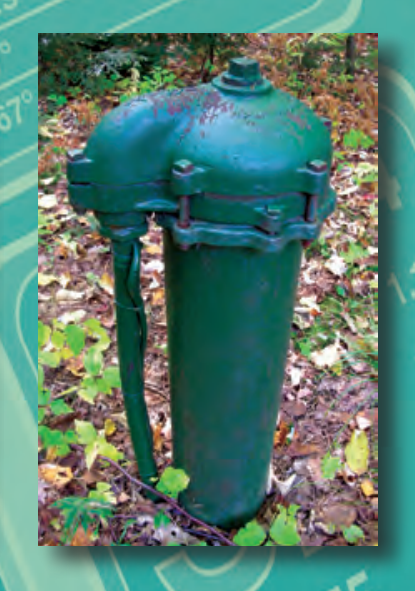

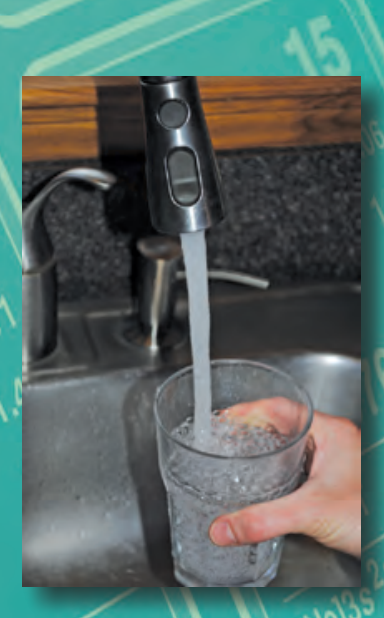

12

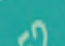

$15^{2}$ 36

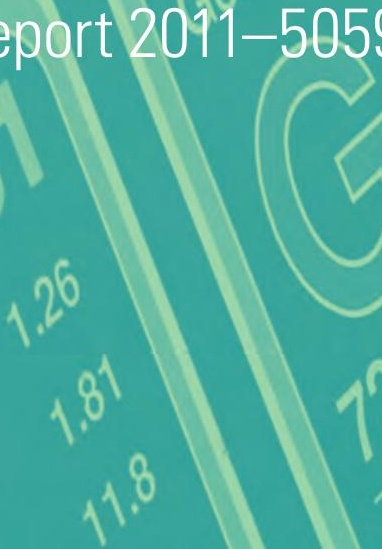

U.S. Department of the Interior

U.S. Geological Survey

(n)

call

aliu 
Cover. Left photograph: Outcrop of crystalline bedrock. (Photograph by James Degnan, U.S. Geological Survey). Middle photograph: Domestic well in crystalline bedrock aquifer. Right photograph: Drinking water from a domestic well. 


\section{Trace Elements and Radon in Groundwater Across the United States, 1992-2003}

By Joseph D. Ayotte, Jo Ann M. Gronberg, and Lori E. Apodaca

National Water-Quality Assessment Program

Scientific Investigations Report 2011-5059 


\section{U.S. Department of the Interior \\ KEN SALAZAR, Secretary \\ U.S. Geological Survey \\ Marcia K. McNutt, Director}

U.S. Geological Survey, Reston, Virginia: 2011

For more information on the USGS - the Federal source for science about the Earth, its natural and living resources, natural hazards, and the environment, visit http://www.usgs.gov or call 1-888-ASK-USGS.

For an overview of USGS information products, including maps, imagery, and publications, visit http://www.usgs.gov/pubprod

To order this and other USGS information products, visit http://store.usgs.gov

Any use of trade, product, or firm names is for descriptive purposes only and does not imply endorsement by the U.S. Government.

Although this report is in the public domain, permission must be secured from the individual copyright owners to reproduce any copyrighted materials contained within this report.

Suggested citation:

Ayotte, J.D., Gronberg, J.M., and Apodaca, L.E., 2011, Trace elements and radon in groundwater across the United States, 1992-2003: U.S. Geological Survey Scientific Investigations Report 2011-5059, 115 p. (Also available at http://pubs.usgs.gov/sir/2011/5059.) 


\section{Foreword}

The U.S. Geological Survey (USGS) is committed to providing the Nation with reliable scientific information that helps to enhance and protect the overall quality of life and that facilitates effective management of water, biological, energy, and mineral resources (http://www.usgs.gov/). Information on the Nation's water resources is critical to ensuring long-term availability of water that is safe for drinking and recreation and is suitable for industry, irrigation, and fish and wildlife. Population growth and increasing demands for water make the availability of that water, measured in terms of quantity and quality, even more essential to the long-term sustainability of our communities and ecosystems.

The USGS implemented the National Water-Quality Assessment (NAWQA) Program in 1991 to support national, regional, State, and local information needs and decisions related to water-quality management and policy (http://water.usgs.gov/nawqa). The NAWOA Program is designed to answer: What is the quality of our Nation's streams and groundwater? How are conditions changing over time? How do natural features and human activities affect the quality of streams and groundwater, and where are those effects most pronounced? By combining information on water chemistry, physical characteristics, stream habitat, and aquatic life, the NAWQA Program aims to provide science-based insights for current and emerging water issues and priorities. From 1991 to 2001, the NAWQA Program completed interdisciplinary assessments and established a baseline understanding of water-quality conditions in 51 of the Nation's river basins and aquifers, referred to as Study Units (http://water.usgs.gov/nawqa/studies/study_units.html).

National and regional assessments are ongoing in the second decade (2001-2012) of the NAWQA Program as 42 of the 51 Study Units are selectively reassessed. These assessments extend the findings in the Study Units by determining water-quality status and trends at sites that have been consistently monitored for more than a decade, and filling critical gaps in characterizing the quality of surface water and groundwater. For example, increased emphasis has been placed on assessing the quality of source water and finished water associated with many of the Nation's largest community water systems. During the second decade, NAWQA is addressing five national priority topics that build an understanding of how natural features and human activities affect water quality, and establish links between sources of contaminants, the transport of those contaminants through the hydrologic system, and the potential effects of contaminants on humans and aquatic ecosystems. Included are studies on the fate of agricultural chemicals, effects of urbanization on stream ecosystems, bioaccumulation of mercury in stream ecosystems, effects of nutrient enrichment on aquatic ecosystems, and transport of contaminants to public-supply wells. In addition, national syntheses of information on pesticides, volatile organic compounds (VOCs), nutrients, trace elements, and aquatic ecology are continuing.

The USGS aims to disseminate credible, timely, and relevant science information to address practical and effective water-resource management and strategies that protect and restore water quality. We hope this NAWQA publication will provide you with insights and information to meet your needs, and will foster increased citizen awareness and involvement in the protection and restoration of our Nation's waters.

The USGS recognizes that a national assessment by a single program cannot address all water-resource issues of interest. External coordination at all levels is critical for cost-effective management, regulation, and conservation of our Nation's water resources. The NAWQA Program, therefore, depends on advice and information from other agencies — Federal, State, regional, interstate, Tribal, and local — as well as nongovernmental organizations, industry, academia, and other stakeholder groups. Your assistance and suggestions are greatly appreciated.

William H. Werkheiser USGS Associate Director for Water 
THIS PAGE INTENTIONALLY LEFT BLANK 


\section{Contents}

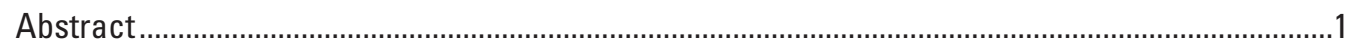

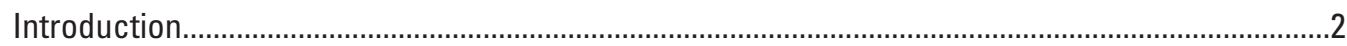

The National Water-Quality Assessment Program .................................................................2

Purpose and Scope ........................................................................................................

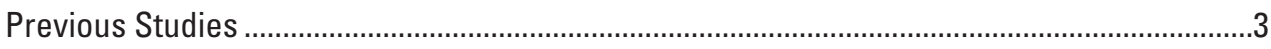

Water-Quality Benchmarks for Human Health .........................................................................

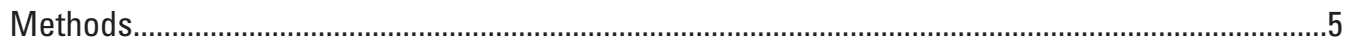

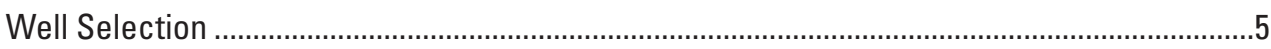

Sample Collection and Analysis ............................................................................................

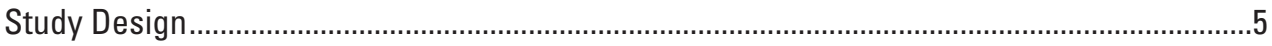

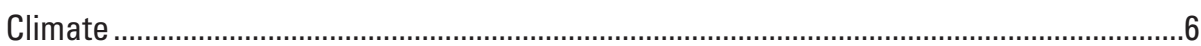

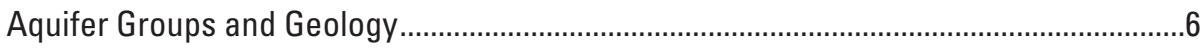

Chemical Evolution and Groundwater Age .............................................................11

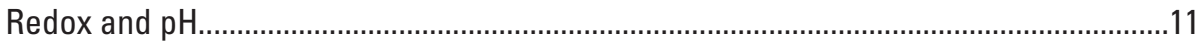

Data Handling and Statistical Methods ...........................................................................14

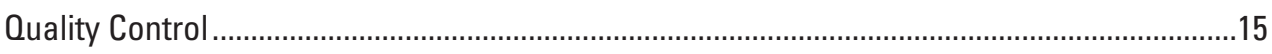

Occurrence of Trace Elements in Groundwater ........................................................................

Trace-Element Occurrence and Concentrations in Monitoring and Drinking-Water Wells..17

Trace-Element Occurrence and Concentrations in Wells in Agricultural and

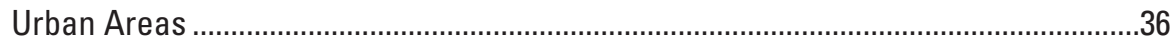

Comparisons of Trace-Element Concentrations in Groundwater to Human-Health

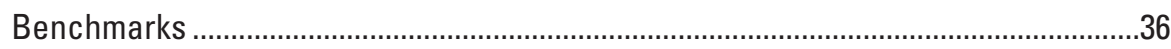

Trace-Element Occurrence and Concentrations in Groundwater by Major Aquifer Group ..38

Unconsolidated Sand and Gravel Aquifers (USG).....................................................39

Glacial Unconsolidated Sand and Gravel Aquifers (GLA)............................................43

Semiconsolidated Sand Aquifers (SCS) ...................................................................44

Sandstone Aquifers (SAN) .................................................................................... 44

Sandstone and Carbonate-Rock Aquifers (SCR) ........................................................4

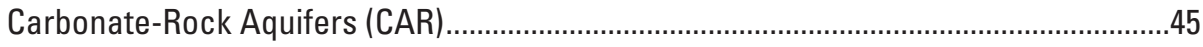

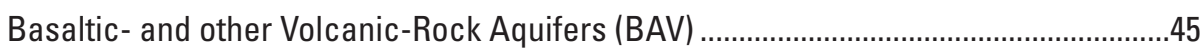

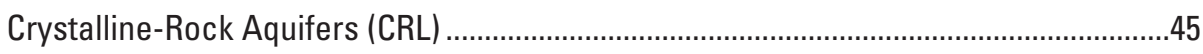

Relation of Selected Trace Elements to pH and Redox State..................................................46

Iron and Manganese .................................................................................................

Aluminum, Copper, Lead, and Zinc............................................................................46

Arsenic, Chromium, Molybdenum, and Selenium ........................................................47

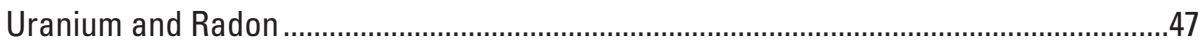

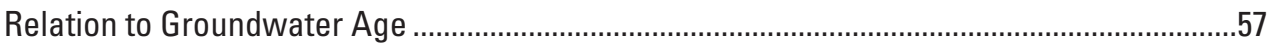

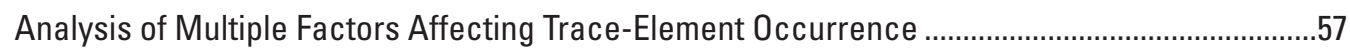

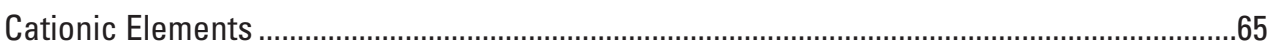

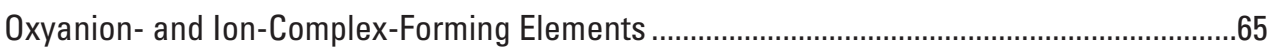

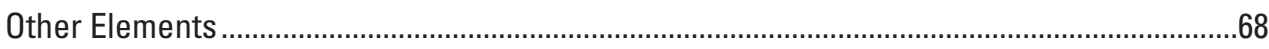

Co-occurrence of Trace Elements at Concentrations Greater than Human-Health

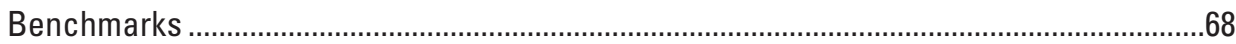


Summary...

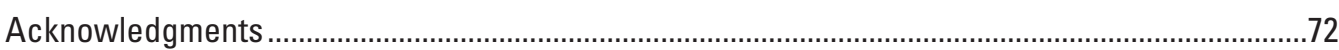

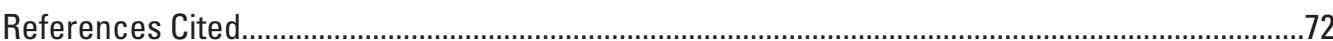

Appendix 1. Selected National-Scale Studies of Trace Elements in Groundwater ......................80

Appendix 2. Wells Sampled by the NAWQA Program, 1992-2003, by Study Type, Land Use, Major Aquifer Group and Aquifer Name

Appendix 3. Summary Statistics and Percent Exceedences of Human-Health Benchmarks and Nonhealth Guidelines for Trace Elements in Groundwater Across the United States Sampled by the NAWQA Program, 1992-2003, by Major Aquifer Group.

Appendix 4. Summary of the Percent Exceedences of Human-Health Benchmarks and Nonhealth Guidelines for Trace Elements in Groundwater Across the United States Sampled by the NAWQA Program, 1992-2003, by pH, Redox State, and Major Aquifer Group

Appendix 5. Summaries of Logistic Regression Analyses of Selected Trace Elements by Major Aquifer Group.

\section{Figures}

1. Maps showing locations of $(A)$ major aquifer study (MAS) wells, and $(B)$ land-use study (LUS) wells sampled for trace elements by the National Water-Quality Assessment Program, 1992-2003.

2. Maps showing $(A)$ generalized categories of oxidation-reduction potential (redox) in samples from wells in humid and dry regions of the United States, and $(B) \mathrm{pH}$ of precipitation in 2001

3. Maps showing $(A)$ principal aquifers of the United States and major aquifer groups used in the current study, and $(B)$ wells sampled by the National Water-Quality Assessment Program, 1992-2003, color coded by aquifer

4. Maps showing geographic distribution of trace-element concentrations in groundwater collected from wells as part of the National Water-Quality Assessment Program, 1992-2003: (A) aluminum, $(B)$ antimony, $(C)$ arsenic, $(D)$ barium, (E) beryllium, (F) boron, $(G)$ cadmium, $(H)$ chromium, (I) cobalt, $(J)$ copper, $(K)$ iron, $(L)$ lead, $(M)$ lithium, $(N)$ manganese, $(O)$ molybdenum, $(P)$ nickel, $(Q)$ radon, $(R)$ selenium, $(S)$ silver, $(T)$ strontium, $(U)$ thallium, $(V)$ uranium, $(W)$ vanadium, and $(X)$ zinc

5. Boxplots showing trace-element concentrations in groundwater across the United States by climate region.

6. Trilinear diagrams showing major-ion chemistry by redox class for $(A)$ unconsolidated sand and gravel aquifers, $(B)$ glacial unconsolidated sand and gravel aquifers, $(C)$ semiconsolidated sand aquifers, (D) sandstone aquifers, (E) sandstone and carbonate-rock aquifers, $(F)$ carbonate-rock aquifers, $(G)$ basaltic- and other volcanic-rock aquifers, and $(H)$ crystalline-rock aquifers.

7. Boxplots showing distributions of $\mathrm{pH}$ by major aquifer group.

8. Boxplots showing the percentage of groundwater samples with trace-element concentrations greater than or equal to the reporting level, by redox and $\mathrm{pH}$ categories, for the major aquifer groups: $(A)$ aluminum, $(B)$ antimony, $(C)$ arsenic, $(D)$ barium, $(E)$ beryllium, (F) boron, $(G)$ cadmium, $(H)$ chromium, (I) cobalt, $(J)$ copper, $(K)$ iron, $(L)$ lead, $(M)$ lithium, $(N)$ manganese, $(O)$ molybdenum, $(P)$ nickel, $(Q)$ radon, $(R)$ selenium, $(S)$ silver, $(T)$ strontium, $(U)$ thallium, $(V)$ uranium, $(W)$ vanadium, and $(X)$ zinc 
9. Boxplots showing the percentages of groundwater samples with trace-element concentrations greater than or equal to 1 microgram per liter for $(A)$ aluminum, $(B)$ lead, $(C)$ copper, and $(D)$ zinc, by $\mathrm{pH}$ and redox category

10. Boxplots showing the percentages of groundwater samples with trace-element concentrations greater than or equal to 1 microgram per liter for $(A)$ aluminum, $(B)$ lead, $(C)$ copper, and $(D)$ zinc in dry- and humid-region unconsolidated sand and gravel aquifers

11. Boxplots showing the percentages of samples with trace-element concentrations greater than or equal to 1 microgram per liter for $(A)$ arsenic, $(B)$ chromium, $(C)$ molybdenum, and (D) selenium, by $\mathrm{pH}$ and redox category

12. Boxplots showing $(A)$ concentrations of arsenic in glacial unconsolidated sand and gravel aquifers $(G L A),(B)$ percentages of samples with arsenic concentrations greater than or equal to 1 microgram per liter in GLA aquifers, $(C)$ concentrations of arsenic in unconsolidated sand and gravel aquifers (USG), and (D) percentages of samples with arsenic concentrations greater than or equal to 1 microgram per liter in USG aquifers

13. Boxplots showing the distribution of $(A)$ dissolved oxygen, $(B)$ well depth, and (C) $\mathrm{pH}$ in groundwater samples by category of age of recharge

14. Boxplots showing percentages of groundwater samples with trace-element concentrations greater than or equal to 1 microgram per liter $(\mu \mathrm{g} / \mathrm{L})(300 \mu \mathrm{g} / \mathrm{L}$ for iron and $50 \mu \mathrm{g} / \mathrm{L}$ for manganese) by category of age of recharge for samples from $(A) \mathrm{dry}$ and $(B)$ humid regions

15. Boxplots showing the percentages of groundwater samples with concentrations greater than reporting level for $(A)$ aluminum $(\mathrm{Al}),(B)$ manganese $(\mathrm{Mn}),(C)$ iron $(\mathrm{Fe})$, and $(D)$ nickel (Ni), by major covariates from logistic regression models

16. Boxplots showing the percentages of groundwater samples with concentrations greater than or equal to 1 microgram per liter for $(A)$ arsenic (As), (B) molybdenum $(\mathrm{Mo}),(C)$ selenium $(\mathrm{Se})$, and $(D)$ uranium $(U)$, by major covariates from logistic regression models 


\section{Tables}

1. Generalized description of the major aquifer groups sampled for the NAWQA Program across the United States..

2. Threshold concentrations for classification of generalized groundwater redox conditions and number of samples collected for the NAWQA Program across the United States by $\mathrm{pH}$ category, 1992-2003.

3. Summary of blank data for trace elements in groundwater sampled for the NAWOA Program, 1992-2003, across the United States .

4. Summary statistics with human-health-benchmark and nonhealth-guideline exceedences for trace elements in groundwater sampled for the NAWQA Program, 1992-2003, across the United States.

5. Summary statistics with human-health-benchmark and nonhealth-guideline exceedences for trace elements in groundwater sampled for the NAWQA Program by climate region, 1992-2003, across the United States.

6. Frequency and distribution statistics for the occurrence of trace elements in groundwater sampled for the NAWQA Program by climate region, 1992-2003, across the United States.

7. Group-comparison statistics for concentrations of trace elements and selected field parameters in groundwater samples collected for the NAWQA Program by climate region and well type, 1992-2003, across the United States

8. Group-comparison statistics for concentrations of trace elements and selected field parameters in groundwater sampled for the NAWQA Program by climate region and land-use type, 1992-2003, across the United States.

9. Percentage of samples collected across the United States for the NAWQA Program from which one or more trace elements exceeded human-health benchmarks by primary water use and study type, 1992-2003

10. Summary of the percentages of exceedences of human-health benchmarks or nonhealth guidelines in samples collected for the NAWQA Program across the United States, 1992-2003, by major aquifer group

11. Summary of logistic regression models for selected trace elements in groundwater sampled for the NAWQA Program across the United States by element and major aquifer group, 1992-2003

12. Number of groundwater samples collected for the NAWQA Program across the United States and number of multiple human-health benchmark exceedences by aquifer group, 1992-2003

13. Co-occurrence of trace elements at concentrations greater than human-health benchmarks in samples collected for the NAWQA Program across the United States from the unconsolidated sand and gravel aquifer group, 1992-2003 ...

14. Co-occurrence of trace elements with boron and strontium at concentrations greater than human-health benchmarks in groundwater samples collected for the NAWQA Program across the United States, 1992-2003 


\section{Conversion Factors, Datum, Acronyms, and Abbreviations}

Inch/Pound to SI

\begin{tabular}{lcl}
\hline \multicolumn{1}{c}{ Multiply } & By & \multicolumn{1}{c}{ To obtain } \\
\hline foot $(\mathrm{ft})$ & Length & \\
mile $(\mathrm{mi})$ & 0.3048 & meter $(\mathrm{m})$ \\
\hline & 1.609 & kilometer $(\mathrm{km})$ \\
\hline picocurie per liter $(\mathrm{pCi} / \mathrm{L})$ & Radioactivity & \\
\hline
\end{tabular}

Vertical coordinate information is referenced to the North American Vertical Datum of 1988 (NAVD 88).

Horizontal coordinate information is referenced to the North American Datum of 1983 (NAD 83).

Altitude, as used in this report, refers to distance above the vertical datum.

Specific conductance is given in microsiemens per centimeter at 25 degrees Celsius $\left(\mu \mathrm{S} / \mathrm{cm}\right.$ at $\left.25^{\circ} \mathrm{C}\right)$.

Concentrations of chemical constituents in water are given either in milligrams per liter (mg/L) or micrograms per liter $(\mu \mathrm{g} / \mathrm{L})$.

Concentrations of radioisotopes in water are given in picocuries per liter (pCi/L).

\section{Chemical symbols}

Al

$\mathrm{Sb}$

As

$\mathrm{Ba}$

$\mathrm{Be}$

B

Cd

$\mathrm{Cr}$

Co

$\mathrm{Cu}$

$\mathrm{Fe}$

$\mathrm{Pb}$

Li

$\mathrm{Mn}$

Mo
Aluminum

Antimony

Arsenic

Barium

Beryllium

Boron

Cadmium

Chromium

Cobalt

Copper

Iron

Lead

Lithium

Manganese

Molybdenum 


$\begin{array}{ll}\mathrm{Ni} & \text { Nickel } \\ \mathrm{Se} & \text { Selenium } \\ \mathrm{Ag} & \text { Silver } \\ \mathrm{Sr} & \text { Strontium } \\ \mathrm{TI} & \text { Thallium } \\ \mathrm{U} & \text { Uranium } \\ \mathrm{V} & \text { Vanadium } \\ \mathrm{Zn} & \text { Zinc } \\ \mathrm{Rn} & \text { Radon }\end{array}$

\section{Aquifer groups}

$\begin{array}{ll}\text { USG } & \text { Unconsolidated sand and gravel aquifers } \\ \text { GLA } & \text { Glacial unconsolidated sand and gravel aquifers } \\ \text { SCS } & \text { Semi-consolidated sand aquifers } \\ \text { SAN } & \text { Sandstone aquifers } \\ \text { SCR } & \text { Sandstone and carbonate-rock aquifers } \\ \text { CAR } & \text { Carbonate-rock aquifers } \\ \text { BAV } & \text { Basaltic- and other volcanic-rock aquifers } \\ \text { CRL } & \text { Crystalline-rock aquifers } \\ \text { USGD } & \text { Unconsolidated sand and gravel aquifers from dry climates } \\ \text { USGH } & \text { Unconsolidated sand and gravel aquifers from humid climates }\end{array}$

\section{Other abbreviations}

$\alpha$

AL

AMCL

CDC

CFC

DO

GCMS

HA

HBSL

HHB
Acceptable statistical significance level for rejecting null hypothesis

Action level

Alternative maximum contaminant level (applies only to proposed radon standard)

U.S. Centers for Disease Control and Prevention

Chlorofluorocarbon

Dissolved oxygen

Gas chromatography/mass spectrometry

Health advisory

Health-based screening level

Human-health benchmark 


$\begin{array}{ll}\text { HPLC } & \text { High performance liquid chromatography } \\ \text { ICP } & \text { Inductively-coupled plasma } \\ \text { ICP-AES } & \text { Inductively-coupled plasma-atomic emission spectroscopy } \\ \text { ICP-MS } & \text { Inductively-coupled plasma-mass spectrometry } \\ \text { LRL } & \text { Laboratory reporting level } \\ \text { LT-MDL } & \text { Long-term method-detection level } \\ \text { LUS } & \text { Land-use study } \\ \text { MAS } & \text { Major aquifer study } \\ \text { MCL } & \text { Maximum contaminant level } \\ N & \text { number of samples } \\ \text { NAWOA } & \text { National Water-Quality Assessment } \\ \text { NWIS } & \text { National Water Information System } \\ p & \text { Attained statistical significance level } \\ \text { OC } & \text { Quality control } \\ R^{2} & \text { Coefficient of determination, or fraction of variance explained by regression } \\ \text { ROS } & \text { Regression-on-order statistics } \\ \text { RPD } & \text { Relative percent difference } \\ \text { RSD } & \text { Relative standard deviation } \\ \text { TDS } & \text { Total dissolved solids } \\ \text { TU } & \text { Tritium units } \\ \text { SMCL } & \text { Secondary maximum contaminant level } \\ \text { SSMDC } & \text { Sample-specific minimum detectable concentration } \\ \text { USEPA } & \text { U.S. Environmental Protection Agency } \\ \text { USGS } & \text { U.S. Geological Survey } \\ \text { VOC } & \text { Volatile organic compound } \\ & \end{array}$


THIS PAGE INTENTIONALLY LEFT BLANK 


\title{
Trace Elements and Radon in Groundwater Across the United States, 1992-2003
}

\author{
By Joseph D. Ayotte, Jo Ann M. Gronberg, and Lori E. Apodaca
}

\section{Abstract}

Trace-element concentrations in groundwater were evaluated for samples collected between 1992 and 2003 from aquifers across the United States as part of the U.S. Geological Survey National Water-Quality Assessment Program. This study describes the first comprehensive analysis of those data by assessing occurrence (concentrations above analytical reporting levels) and by comparing concentrations to humanhealth benchmarks (HHBs). Data from 5,183 monitoring and drinking-water wells representing more than 40 principal and other aquifers in humid and dry regions and in various land-use settings were used in the analysis. Trace elements measured include aluminum (Al), antimony ( $\mathrm{Sb})$, arsenic (As), barium (Ba), beryllium (Be), boron $(\mathrm{B})$, cadmium $(\mathrm{Cd})$, chromium $(\mathrm{Cr})$, cobalt $(\mathrm{Co})$, copper $(\mathrm{Cu})$, iron $(\mathrm{Fe})$, lead $(\mathrm{Pb})$, lithium (Li), manganese (Mn), molybdenum (Mo), nickel (Ni), selenium (Se), silver (Ag), strontium (Sr), thallium (Tl), uranium (U), vanadium (V), and zinc (Zn). Radon (Rn) gas also was measured and is included in the data analysis.

Climate influenced the occurrence and distribution of trace elements in groundwater whereby more trace elements occurred and were found at greater concentrations in wells in drier regions of the United States than in humid regions. In particular, the concentrations of $\mathrm{As}, \mathrm{Ba}, \mathrm{B}, \mathrm{Cr}, \mathrm{Cu}, \mathrm{Mo}, \mathrm{Ni}, \mathrm{Se}$, $\mathrm{Sr}, \mathrm{U}, \mathrm{V}$, and $\mathrm{Zn}$ were greater in the drier regions, where processes such as chemical evolution, ion complexation, evaporative concentration, and redox (oxidation-reduction) controls act to varying degrees to mobilize these elements. Al, Co, Fe, $\mathrm{Pb}$, and $\mathrm{Mn}$ concentrations in groundwater were greater in humid regions of the United States than in dry regions, partly in response to lower groundwater $\mathrm{pH}$ and (or) more frequent anoxic conditions. In groundwater from humid regions, concentrations of $\mathrm{Cu}, \mathrm{Pb}, \mathrm{Rn}$, and $\mathrm{Zn}$ were significantly greater in drinking-water wells than in monitoring wells.

Samples from drinking-water wells in dry regions had greater concentrations of $\mathrm{As}, \mathrm{Ba}, \mathrm{Pb}, \mathrm{Li}, \mathrm{Sr}, \mathrm{V}$, and $\mathrm{Zn}$, than samples from monitoring wells. In humid regions, however, concentrations of most trace elements were greater in monitoring wells than in drinking-water wells; the exceptions were $\mathrm{Cu}, \mathrm{Pb}, \mathrm{Zn}$, and $\mathrm{Rn}$. $\mathrm{Cu}, \mathrm{Pb}$, and $\mathrm{Zn}$ are common trace elements in pumps and pipes used in the construction of drinking-water wells, and contamination from these sources may have contributed to their concentrations. Al, Sb, Ba, B, $\mathrm{Cr}, \mathrm{Co}, \mathrm{Fe}, \mathrm{Mn}, \mathrm{Mo}, \mathrm{Ni}, \mathrm{Se}, \mathrm{Sr}$, and $\mathrm{U}$ concentrations were all greater in monitoring wells than in drinking-water wells in humid regions.

Groundwater from wells in agricultural settings had greater concentrations of As, Mo, and $\mathrm{U}$ than groundwater from wells in urban settings, possibly owing to greater $\mathrm{pH}$ in the agricultural wells. Significantly greater concentrations of $\mathrm{B}, \mathrm{Cr}, \mathrm{Se}, \mathrm{Ag}, \mathrm{Sr}$, and $\mathrm{V}$ also were found in agricultural wells in dry regions. Groundwater from dry-region urban wells had greater concentrations of $\mathrm{Co}, \mathrm{Fe}, \mathrm{Pb}, \mathrm{Li}, \mathrm{Mn}$, and specific conductance than groundwater from agricultural wells.

The geologic composition of aquifers and aquifer geochemistry are among the major factors affecting trace-element occurrence. Trace-element concentrations in groundwater were characterized in aquifers from eight major groups based on geologic material, including (1) unconsolidated sand and gravel; (2) glacial unconsolidated sand and gravel; (3) semiconsolidated sand; (4) sandstone; (5) sandstone and carbonate rock; (6) carbonate rock; (7) basaltic and other volcanic rock; and (8) crystalline rock. The majority of groundwater samples and the largest percentages of exceedences of HHBs were in the glacial and nonglacial unconsolidated sand and gravel aquifers; in these aquifers, As, Mn, and $\mathrm{U}$ are the most common trace elements exceeding HHBs.

Overall, 19 percent of wells (962 of 5,097) exceeded an HHB for at least one trace element. The trace elements with $\mathrm{HHBs}$ included in this summary were $\mathrm{Sb}, \mathrm{As}, \mathrm{Ba}, \mathrm{Be}$, B, Cd, Cr, Cu, Pb, Mn, Mo, Ni, Se, Ag, Sr, Tl, U, and Zn. Mn occurred most often at concentrations greater than its humanhealth benchmark (12 percent), followed by As (7.0 percent), Sr (4.3 percent), U (4.0 percent), B (1.9 percent), and Mo (1.5 percent). Rn occurred at concentrations greater than the U.S. Environmental Protection Agency (USEPA) proposed maximum contaminant level of $300 \mathrm{pCi} / \mathrm{L}$ in more than 65 percent of water samples, and concentrations of $R n$ in 2.7 percent of samples were greater than the USEPA-proposed alternate maximum contaminant level of 4,000 pCi/L. There were more exceedences of HHBs in the dry-region groundwater than in the humid-region groundwater. 
Groundwater $\mathrm{pH}$ and redox conditions were significant factors for the occurrence of many trace elements. Low $\mathrm{pH}$ (less than 7) was a significant factor in the occurrence of many cationic metals, such as $\mathrm{Al}, \mathrm{Fe}, \mathrm{Mn}$, and $\mathrm{Ni}$; these metals, as well as $\mathrm{Cu}, \mathrm{Pb}$, and $\mathrm{Zn}$, adsorb more strongly to aquifer materials as $\mathrm{pH}$ increases. Anoxic conditions often were related to the increased occurrence of many oxyanion-forming elements, such as As, Cr, and Mo, whereas oxic conditions often were related to higher Se occurrence. Groundwater redox and $\mathrm{pH}$ effects were evident for As, Cr, Mo, and Se. Based on all samples, As occurrence generally increased as geochemical conditions became increasingly anoxic for groundwater with $\mathrm{pH}$ less than 7, but was consistently high for samples with $\mathrm{pH}$ greater than 7. A similar pattern was evident for Mo and, to a lesser extent, $\mathrm{Cr}$. For groundwater in aquifers in glacial unconsolidated sand and gravel, however, As occurrence increased as groundwater became increasingly anoxic and as $\mathrm{pH}$ increased, indicating that redox is an important process throughout the range of $\mathrm{pH} . \mathrm{Al}, \mathrm{Cu}, \mathrm{Pb}$, and $\mathrm{Zn}$ occurred more often in low-pH groundwater and, except for $\mathrm{Al}$, in oxic conditions.

In general, older waters (mostly pre-1953) had more occurrences of trace elements, greater $\mathrm{pHs}$, were from deeper wells, and had lower concentrations of dissolved oxygen than younger waters (defined as waters containing a fraction younger than 1953). Most oxyanion-forming trace elements occurred more frequently in old groundwater. However, although $\mathrm{U}$ occurrence was greater in older water collected from dry-region aquifers, $U$ occurred more often in young water in humid-region aquifers. This difference may be related to old, humid-region groundwater having lower concentrations of dissolved oxygen, a condition which can inhibit U mobility.

Overall, As co-occurred primarily with silica $\left(\mathrm{SiO}_{2}\right)$ and $\mathrm{Mo}$ in water with slightly high $\mathrm{pH}$. About 12 percent of water samples without $\mathrm{SiO}_{2}$ or Mo had concentrations of As greater than or equal to $1 \mu \mathrm{g} / \mathrm{L}$. This number increased to about 45 percent if either Mo or silica were present and to about 85 percent if both $\mathrm{Mo}$ and $\mathrm{SiO}_{2}$ were present. From a subset of water samples selected from 2,714 wells for co-occurrence analysis, samples from 572 wells (21.1 percent) had HHB exceedences of one or more trace elements. Of the 2,714 samples, 62 (2.3 percent) had two or more trace elements that exceeded HHBs. Fifty of the 62 ( 80 percent) were from unconsolidated sand and gravel aquifers and involved at least As and $\mathrm{Mn}, \mathrm{Mn}$ and $\mathrm{U}$, or As and $\mathrm{U}$.

\section{Introduction}

In 2000, groundwater accounted for about 46 percent of water used in the United States, with about 31 percent of use for public supply and about 15 percent from domestic wells (also known as private wells). Total withdrawals from groundwater have generally increased over the past 5 decades along with increases in population (Hutson and others, 2004). For example, groundwater withdrawals of freshwater increased by 9 percent from 1995 to 2000, and population increased by 7 percent over the same period (Hutson and others, 2004). Trace elements in groundwater used for drinking have long been a concern because of potential adverse effects on human health. Many trace elements in drinking water can have adverse health effects at high concentrations, whereas others may present aesthetic or nuisance problems.

As used in this report, the term "trace elements" refers to metals and semimetallic elements that typically are found in concentrations less than $1 \mathrm{mg} / \mathrm{L}$ in natural waters (Hem, 1985). These elements are mobilized primarily from rock weathering, and their concentrations in groundwater reflect their presence and abundance in aquifer materials, geochemical conditions (such as $\mathrm{pH}$ and oxidation-reduction potential), the presence and abundance of complexing ions and organic matter, and attenuation processes such as adsorption (Hem, 1985; Salbu and Steinnes, 1994). Human activities, such as mining and waste disposal, also can affect concentrations of trace elements in groundwater.

Studies worldwide have shown that high concentrations of trace elements can have adverse effects on human health (Wu and others, 1989; Haglund and others, 1996; HopenhaynRich and others, 1996; Cantor, 1997; Karagas and others, 1998; National Academy of Sciences, 1999; Chappell and others, 2001; Karagas and others, 2001; Smedley and others, 2001; Kendall and Smith, 2002; Smedley, 2003; Seiler, 2004; Selinus and others, 2005; Wasserman and others, 2006; Meliker and others, 2007; Walker and others, 2008). Several trace elements, including arsenic, cadmium, chromium, lead, and radon gas, have known and established toxicity (Selinus and others, 2005). Other trace elements, such as copper and selenium, in too small an amount, can cause adverse health outcomes (Selinus and others, 2005; Chrosniak and others, 2006). Because many trace elements are widely dispersed in rocks and unconsolidated materials, the individual occurrence rate of a specific trace element may be low, but the overall chance of having at least one trace element of concern in a water sample may be relatively high. Because of differences in well characteristics and regulations, concentrations of trace elements in groundwater from domestic wells could differ from those in groundwater withdrawn from public wells. Thus, the distinction between drinking waters supplied by public and domestic wells may be a significant factor for health scientists assessing exposure to trace elements through drinking water.

\section{The National Water-Quality Assessment Program}

Knowledge of the quality of the Nation's streams and aquifers is important because of the effect on human and aquatic health and the substantial costs associated with decisions involving land and water management, conservation, and regulation. Understanding regional patterns and environmental 
factors affecting trace-element concentrations in streams and groundwater is essential for effectively developing programs to manage and protect these water resources and human health. The U.S. Geological Survey (USGS) National WaterQuality Assessment (NAWQA) Program was implemented in 1991 to improve the scientific and public understanding of water quality in the Nation's major river basins and groundwater systems. The goals of the NAWQA Program are to describe current water-quality conditions and trends in the Nation's rivers and groundwater to determine the natural characteristics and human influences that affect water quality (Gilliom and others, 1995).

Groundwater quality in the United States has been characterized by the NAWQA Program through studies that use nationally consistent methods and are distributed within 51 major river basins and aquifers nationwide (figs. $1 \mathrm{~A}$ and $\mathrm{B}$ ). The analysis in this report is based on NAWQA Program data collected from 1992 to 2003. More information on the design, components, and current activities of the NAWQA Program is available (Gilliom and others, 1995; Lapham and others, 1995; Rosen and Lapham, 2008). Prior to 1999, trace-element sampling in groundwater was mainly done for NAWQA major aquifer studies (MASs) and to a lesser extent for agricultural and urban land-use studies (LUSs). Trace-element sampling was fully implemented in the NAWQA Program in 1999.

\section{Purpose and Scope}

The primary purpose of this report is to describe the occurrence and distribution of 23 trace elements and radon (Rn) in water from wells sampled by the USGS NAWQA Program from 1992 to 2003. The term occurrence is used in this report to describe concentrations of trace elements above a specified analytical reporting level - in most cases $1 \mu \mathrm{g} / \mathrm{L}$, unless otherwise noted. The analyses presented are based on single samples from 5,183 wells. The trace elements evaluated include aluminum ( $\mathrm{Al})$, antimony $(\mathrm{Sb})$, arsenic $(\mathrm{As})$, barium $(\mathrm{Ba})$, beryllium $(\mathrm{Be})$, boron $(\mathrm{B})$, cadmium $(\mathrm{Cd})$, chromium $(\mathrm{Cr})$, cobalt $(\mathrm{Co})$, copper $(\mathrm{Cu})$, iron $(\mathrm{Fe})$, lead $(\mathrm{Pb})$, lithium (Li), manganese (Mn), molybdenum (Mo), nickel (Ni), selenium (Se), silver (Ag), strontium $(\mathrm{Sr})$, thallium $(\mathrm{Tl})$, uranium $(\mathrm{U})$, vanadium $(\mathrm{V})$, and zinc $(\mathrm{Zn})$. Rn, a direct decay product of ${ }^{226}$ radium, was included because of its known adverse effects on human health (U.S. Environmental Protection Agency, 2010). Physical properties (pH, dissolved oxygen (DO) concentration, specific conductance, and water temperature) and concentrations of major inorganic constituents and nutrients also were measured.

The occurrence and distribution of trace elements in groundwater is described at the national scale and by major aquifer group (groups of principal and other aquifers) with a focus on areas where concentrations of trace elements from wells exceed health-based standards. As part of this objective, measured trace-element concentrations in groundwater are compared to U.S. Environmental Protection Agency (USEPA) drinking-water standards and proposed standards (for Rn) including maximum contaminant levels (MCL), health advisories (HA), and action levels (AL) - and to HealthBased Screening Levels (HBSLs) published by the USGS (Toccalino and Norman, 2006). Collectively, these are referred to as human-health benchmarks (HHBs). Also compared are selected secondary maximum contaminant levels (SMCL), which are nonhealth guidelines.

Additional objectives include (1) the identification of factors that relate to the occurrence of selected trace elements, such as geochemistry, redox, and age of groundwater; and (2) the analysis of co-occurrence of selected trace elements in individual wells where more than one trace element exceeds HHBs.

\section{Previous Studies}

It is beyond the scope of this report to provide a comprehensive bibliography of trace-element studies in the United States. The reader is referred to several resources that provide an excellent overview of previous studies of trace-element sources and mobility (Freeze and Cherry, 1979; Drever, 1988; Hem, 1985). Few systematic evaluations of multiple trace elements in groundwater at the scale of this study have been undertaken in the United States. Selected national- and regional-scale studies that are particularly relevant to the current analysis are listed in appendix 1.

Previous studies of trace elements in groundwater throughout the United States have identified important relations among controls on occurrence and mobility. Also, the literature on factors that govern trace-element sources and mobility in specific regions of the United States is extensive, and some studies have compared data across regions. In most studies, however, only one trace element was assessed, or a few trace elements from a particular group (such as As or selected radionuclides) were evaluated, leaving gaps in the available information to assess trace-element occurrence and no opportunity to assess the co-occurrence of trace elements.

\section{Water-Quality Benchmarks for Human Health}

The human-health benchmarks used in this study include MCLs and ALs established by the USEPA for public-water supplies (U.S. Environmental Protection Agency, 2004) and HBSLs derived from the analysis of toxicology data for specific contaminants (Toccalino and Norman, 2006). In most cases, the HBSLs are equivalent to USEPA HAs, although HBSLs are updated more often as new toxicological data become available. Although not all of the wells analyzed for this report were used for drinking water, they were all selected with the aim of characterizing trace-element concentrations in aquifers across the United States. Thus, comparisons of traceelement concentrations to HHBs are not intended to represent potential exposure but rather to indicate where and under what conditions groundwater in important aquifers is affected. The 


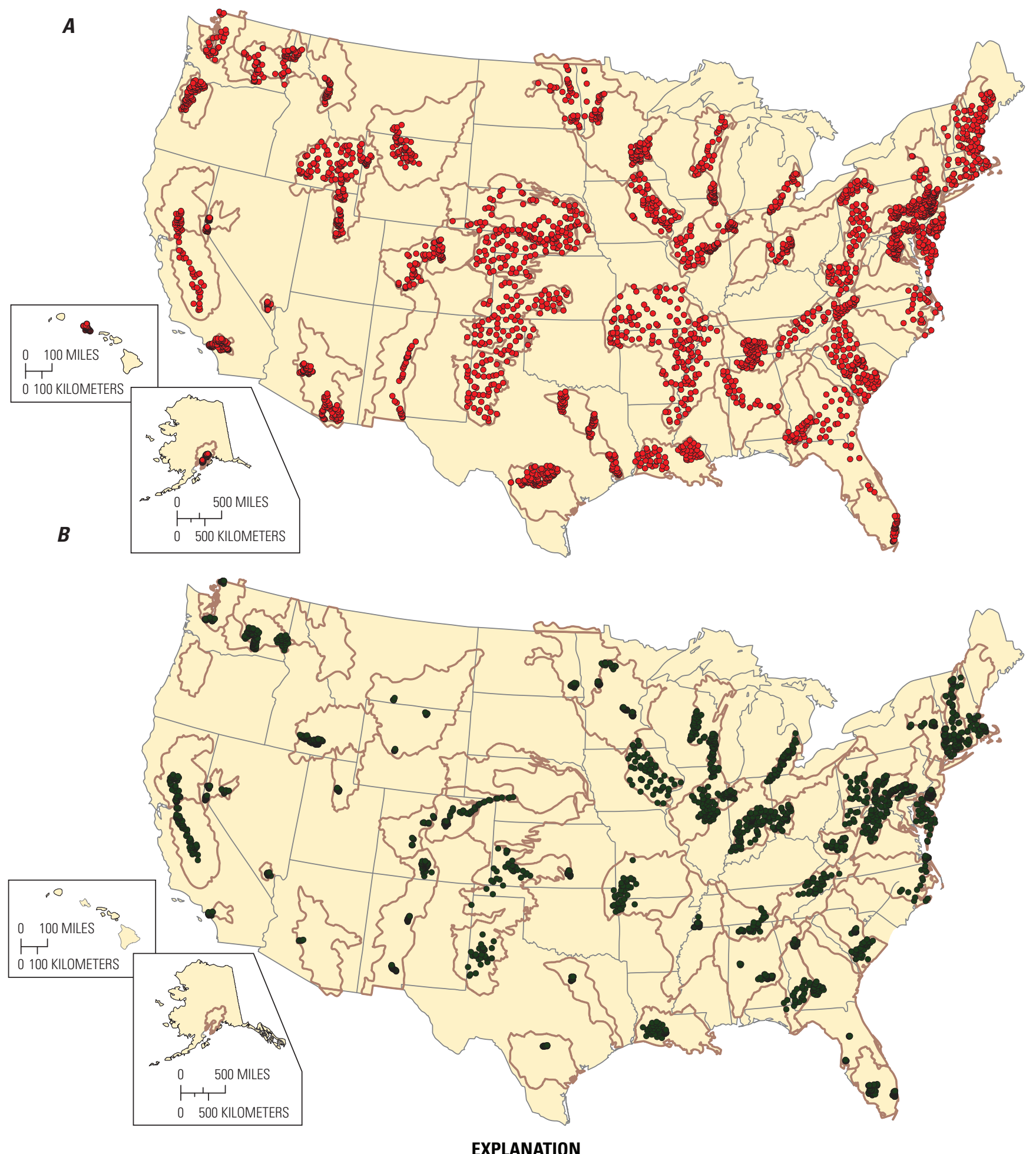

— NAWQA study areas

- Major aquifer study wells

- Land-use study wells

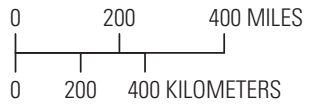

Figure 1. Locations of $(A)$ major aquifer study (MAS) wells, and (B) land-use study (LUS) wells sampled for trace elements by the National Water-Quality Assessment Program, 1992-2003. 
USEPA has established enforceable MCLs for $\mathrm{Sb}, \mathrm{As}, \mathrm{Ba}, \mathrm{Be}$, $\mathrm{Cd}, \mathrm{Cr}, \mathrm{Se}, \mathrm{Tl}$, and $\mathrm{U}$. ALs have been established for $\mathrm{Cu}$ and $\mathrm{Pb}$, and exceedence of these ALs triggers possible treatment or other requirements for a water system. Currently an MCL and alternative MCL (AMCL) have been proposed for Rn. HBSLs, similar to USEPA HAs, are acceptable levels based on health information (nonenforceable) and have been established for B, Mn, Mo, Ni, Ag, Sr, and Zn (Toccalino and Norman, 2006). Nonhealth guidelines, such as SMCLs, are nonenforceable and pertain to water aesthetics, such as for $\mathrm{Al}$ and Fe. Three of the trace elements discussed in this report $(\mathrm{Co}, \mathrm{Li}$, and $\mathrm{V})$ do not have USEPA drinking-water standards (U.S. Environmental Protection Agency, 2004) or HBSLs.

\section{Methods}

This study used data collected by the USGS NAWQA Program to characterize trace-element concentrations in major aquifer groups across the United States. The data were analyzed primarily by determining their distributions and comparing those distributions to factors such as climate, composition of geologic materials, well types, well depths, $\mathrm{pH}$, and redox conditions. A variety of methods were used to develop the data used in the analyses and to identify factors influencing trace element concentrations in groundwater.

\section{Well Selection}

Wells included in this study are from NAWQA studies designed to describe the quality of water withdrawn from major aquifers and used for drinking (termed major aquifer studies or MASs) and studies of shallow groundwater within specific land-use settings (termed land-use studies or LUSs) (Gilliom and others, 1995). MASs focused on the quality of groundwater resources throughout an aquifer and used data mostly from existing supply wells irrespective of depth. LUSs targeted the uppermost recently recharged groundwater to identify the effects of the overlying land use and used data mostly from monitoring wells and some supply wells. Individual MASs and LUSs are described in reports for individual NAWQA study areas (see http://water.usgs.gov/ nawqa/). The sampling network for each study comprised about 30 wells that were randomly selected within the target area by a geographically distributed sampling method (Scott, 1990). A total of 5,183 wells from which geologic and chemical data had been collected were from networks in 48 NAWQA study areas across the United States (fig. 1). The actual numbers of wells used in the analyses were based on whether or not a particular trace element was analyzed in water from a well or on the availability of ancillary data for that analysis. Additional information on sampling networks and wells is shown in appendix 2.

Specific well-selection protocols designed by the NAWQA Program were used in the design of the MASs and
LUSs (Lapham and others, 1995). Ancillary data for each well were collected according to NAWQA protocols (Koterba and others, 1995) and included latitude and longitude, topographic setting, well depth, open interval, casing diameter and material, geologic materials and (or) aquifers contributing water to the well, static water level, potential point sources of contamination near the well, and land use within 50 and $500 \mathrm{~m}$ of the well.

\section{Sample Collection and Analysis}

Groundwater was collected and analyzed for trace elements, major ions, nutrients, tritium, chlorofluorocarbons (CFCs), and other constituents in accordance with NAWQA protocols (Koterba and others, 1995; Lapham and others, 1995). Prior to collection, wells were pumped until the water temperature, DO, specific conductance, and $\mathrm{pH}$ were stable (Koterba and others, 1995). Cleaned polytetrafluoroethylene (PTFE) tubing with stainless-steel fittings was connected to either a submersible pump or to a water line close to the wellhead. Groundwater was collected at a flow rate of $0.5 \mathrm{~L} / \mathrm{min}(0.0083 \mathrm{~L} / \mathrm{s})$ in a portable sampling chamber. Samples for trace elements were passed through a $0.45-\mu \mathrm{m}$ disposable polypropylene capsule filter; the trace-element samples were then acidified with ultra pure nitric acid to a $\mathrm{pH}$ of less than 2. Trace elements were analyzed at the USGS National Water Quality Laboratory in Denver, Colo., by using inductively coupled plasma atomic-emission spectrometry (ICP-AES), inductively coupled plasma mass spectrometry (ICP-MS), graphite-furnace atomic-absorption spectrometry (AA), or hydride generation atomic-absorption spectrometry (Fishman and Friedman, 1989; Faires, 1993; McLain, 1993; Ivahnenko and others, 1996; Garbarino, 1999; Ivahnenko and others, 2001). Laboratory reporting levels (LRLs) generally ranged from 0.2 to $1 \mu \mathrm{g} / \mathrm{L}$, except for the LRLs for Fe and B, which were higher. Concentrations of Rn were analyzed by liquid scintillation methods; LRLs for Rn ranged from 52 to $80 \mathrm{pCi} / \mathrm{L}$ (Prichard and Gessell, 1977; Mullin and Wanty, 1991).

\section{Study Design}

Several factors affect trace-element solubility and mobility. In this study, data were analyzed in relation to climate, the geology of aquifer materials, aquifer geochemistry, and the redox potential and $\mathrm{pH}$ of the groundwater. The ancillary data used in the data analyses represent regional- to national-scale conditions. Depending on the scale of the analysis, variables such as climate, geology, $\mathrm{pH}$, and redox can be used to explain differences in trace-element concentrations in groundwater. However, when concentrations of trace elements in groundwater are analyzed at the major aquifer scale, the effect of climate becomes diminished because most aquifer groups are limited in spatial extent and are in either predominantly dry or humid regions. 
Trace Elements and Radon in Groundwater Across the United States, 1992-2003

\section{Climate}

In general, concentrations of trace elements are greater in drier climates of the United States, owing to processes such as redox condition, ion competition, complexation, evaporative concentration, and to more chemically evolved groundwater conditions (Hem, 1985; Welch and others, 2000; McMahon and Chapelle, 2008). To characterize general climatic conditions in the United States, a climate variable indicating generally dry or generally humid conditions for North America was used (fig. 2A) (Commission for Environmental Cooperation Working Group, 1997). With a few exceptions, the western United States has a generally dry climate, whereas the east is generally humid (fig. 2A). Local studies have shown that the effects of drier climates can favor increased groundwater concentrations of trace elements, such as Se (Dubrovsky and others, 1993; Seiler and others, 2003), As (Seiler, 2004; Thiros and Manning, 2004), B, Mo, and U (Fujii and Swain, 1995; Welch and Lico, 1998). In humid regions, by contrast, larger groundwater fluxes and shorter groundwater residence times may result in lower $\mathrm{pH}$, favoring mobility of trace elements such as $\mathrm{Al}, \mathrm{Fe}, \mathrm{Mn}, \mathrm{Pb}$, and $\mathrm{Zn}$ to a greater extent than in dry regions. In addition, precipitation in much of the humid east has been more acidic than in the west (National Atmospheric Deposition Program, 2001) (fig. 2B); greater acidity can lead to increased weathering of geologic materials containing trace elements and potentially greater mobility of those elements in groundwater young enough (post-1960) to be affected by that precipitation (Jacks, 1993).

\section{Aquifer Groups and Geology}

Most trace elements in groundwater are derived from minerals in the rocks and sediment through which groundwater flows; thus, regional and subregional differences in geology can have implications for trace-element occurrence in groundwater. For example, some Cretaceous-age deposits of the central Great Plains have been shown to contain labile concentrations of As, B, Cr, Cu, Ni, Se, V, and U (Tourtelot, 1956). Some materials derived from these deposits have been shown to be related to high concentrations of Se in groundwater and surface water in parts of the western United States (Seiler and others, 2003). Arsenic occurrence in groundwater may be similarly controlled by availability in aquifer materials, as well as by groundwater geochemistry (Welch and others, 2000; Smedley and Kinniburgh, 2002; Welch and Stollenwerk, 2003; Thomas, 2007). Aquifers in some carbonate lithologies, such as the Floridan aquifer system and parts of the Edwards-Trinity aquifer system in Texas, have high concentrations of Sr that ultimately affect the concentrations in the associated groundwater (Hanshaw and Back, 1979; Back and others, 1988; Musgrove and Banner, 2004). Although most trace elements in groundwater are from natural sources, it is important to note that the sources of some trace elements in groundwater may be anthropogenic, and that some naturally occurring trace elements can be mobilized by anthropogenic activities (Böhlke, 2002; Seiler and others, 2003; Stollenwerk and Colman, 2004; Eberts and others, 2005; deLemos and others, 2006; Dubrovsky and others, 2010; Ayotte and others, 2011).

For this study, more than 40 aquifers were divided into 8 major aquifer groups based on the geologic materials from which they derive water (table 1; fig. 3). These groups are based on important aquifers in the United States (Miller, 2000) and the principal aquifers of the United States map (U.S. Geological Survey, 2003). Principal aquifers are defined as aquifers that are regionally extensive and can yield useable quantities of water (U.S. Geological Survey, 2003). The eight major aquifer groups used in this report are (1) unconsolidated sand and gravel aquifers; (2) glacial unconsolidated sand and gravel aquifers; (3) semiconsolidated sand aquifers; (4) sandstone aquifers; (5) sandstone and carbonate-rock aquifers; (6) carbonate-rock aquifers; (7) basaltic- and other volcanicrock aquifers; and (8) crystalline-rock aquifers.

In most cases, wells in the major aquifer groups used in this study are predominantly in either dry or humid regions. The primary exceptions are the wells in the unconsolidated sand and gravel aquifers and the sandstone and carbonate-rock aquifer groups, in which the number of wells is split more evenly between dry and humid regions of the United States (table 1).

Some principal aquifers (and aquifer systems) contain deposits from multiple types of geologic materials. In this study, however, the composition of geologic materials was a primary factor in analyzing the water chemistry data so that individual wells from the same principal aquifer could be grouped into different categories based on rock type. An example of this is the Valley and Ridge aquifers, which are listed as sandstone and carbonate-rock aquifers on the principal aquifer map of the United States (U.S. Geological Survey, 2003) and described together in the Ground Water Atlas of the United States (Miller, 2000). For this analysis, the Valley and Ridge aquifers were separated into the sandstone aquifer group and the carbonate-rock aquifer group. This was done to account for differences in geochemical conditions, which can differ widely between these rock types. In addition, crystalline-rock aquifers in New York and New England (Miller, 2000) and in the Rocky Mountain Front Range, which are described as "other" aquifers on the principal aquifers map of the United States (U.S. Geological Survey, 2003), were included in this report as unofficially named aquifers in the crystalline-rock aquifer group. Also in this report, unconsolidated deposits were separated into groups of unconsolidated aquifers of glacial origin and unconsolidated aquifers of nonglacial origin. The glacial sand and gravel aquifers include deposits of both Laurentide and Cordilleran continental glaciations (Warner and Arnold, 2006). Additional information about aquifer groups, principal aquifers, and other aquifers is available at http:/water.usgs.gov/nawqa/studies/ praq/ or http://pubs.usgs.gov/ha/ha730/gwa.html. 

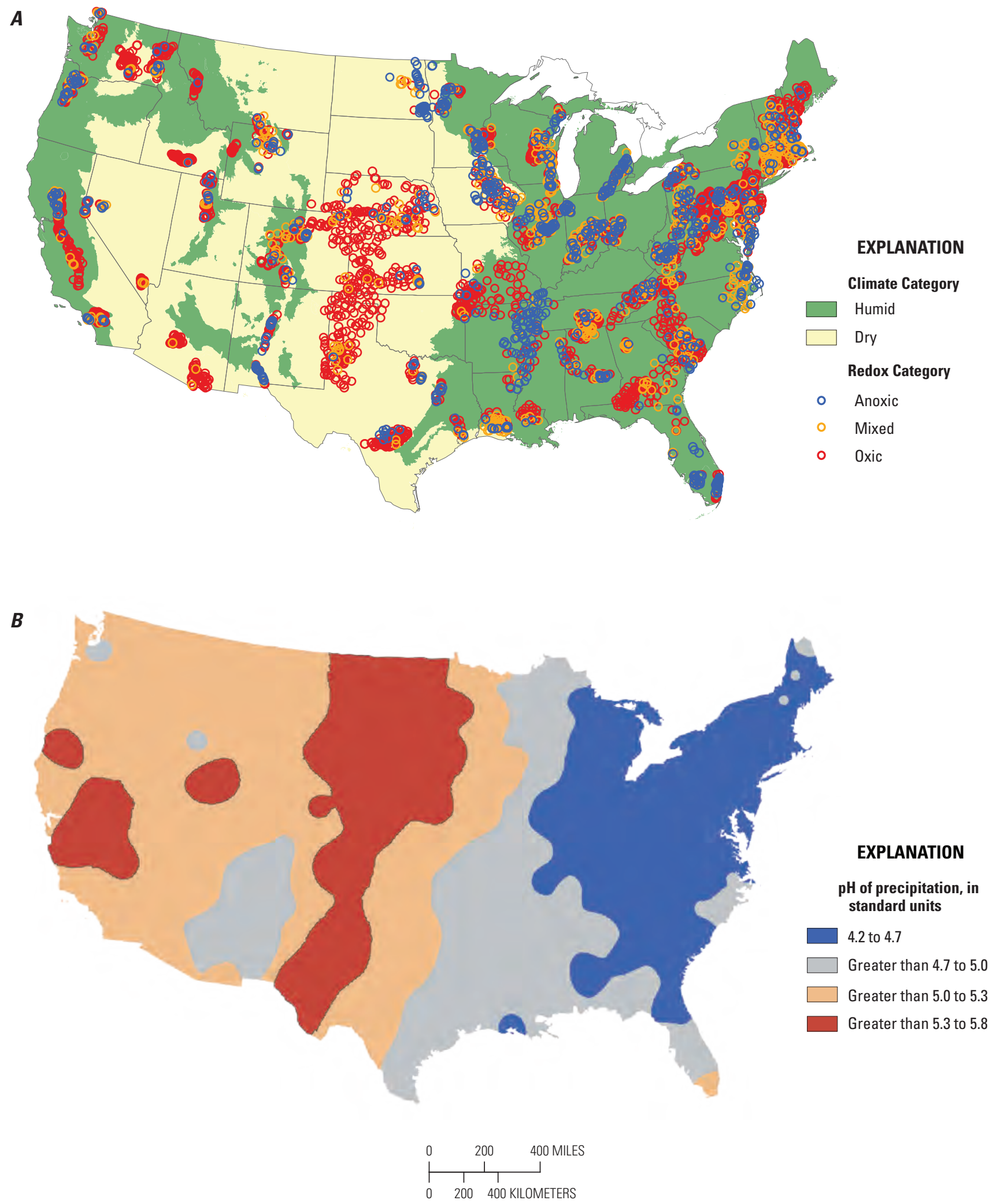

Figure 2. (A) Generalized categories of oxidation-reduction potential (redox) in samples from wells in humid and dry regions of the United States (Commission for Environmental Cooperation Working Group, 1997), and (B) pH of precipitation in 2001 (National Atmospheric Deposition Program, 2001). 


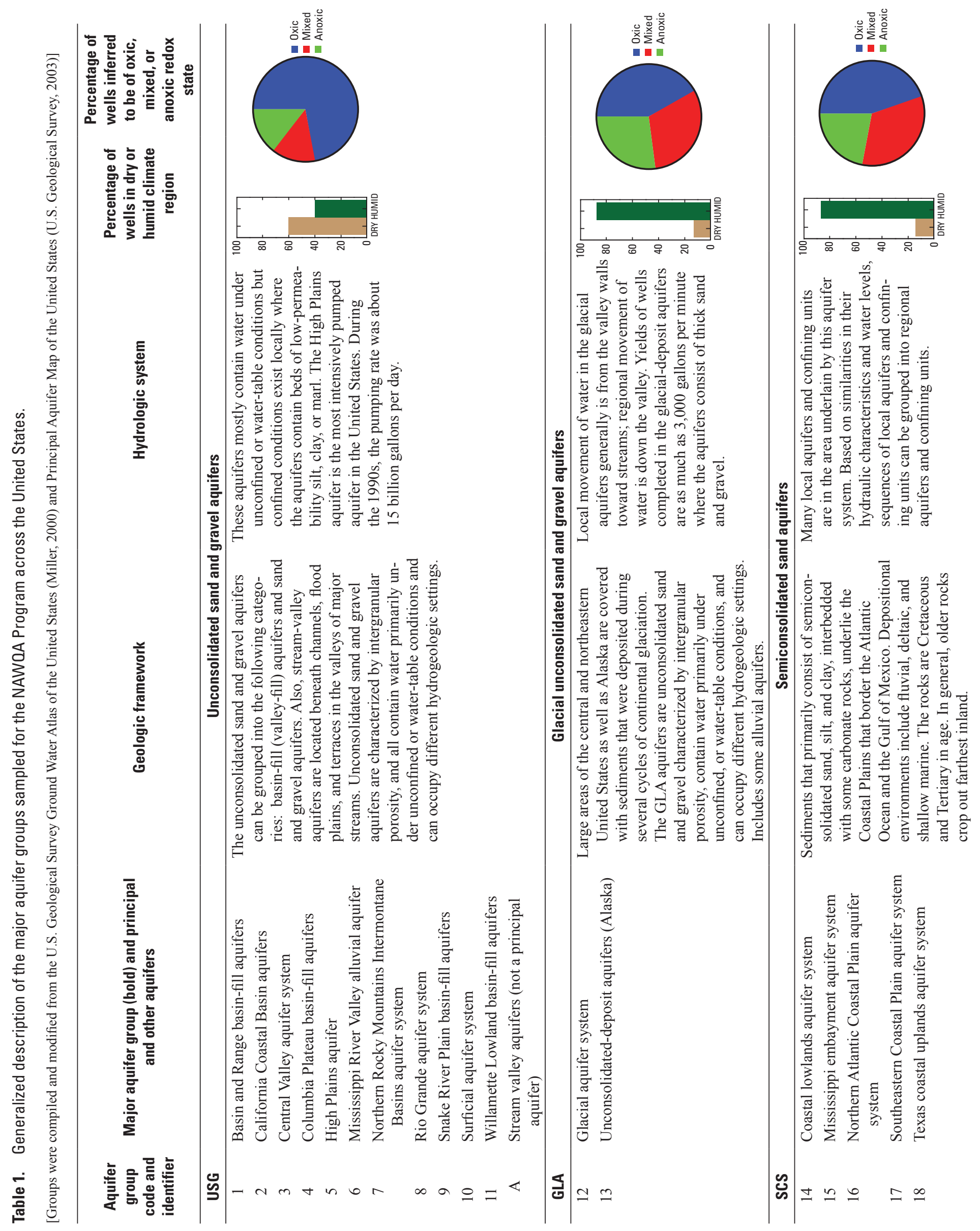




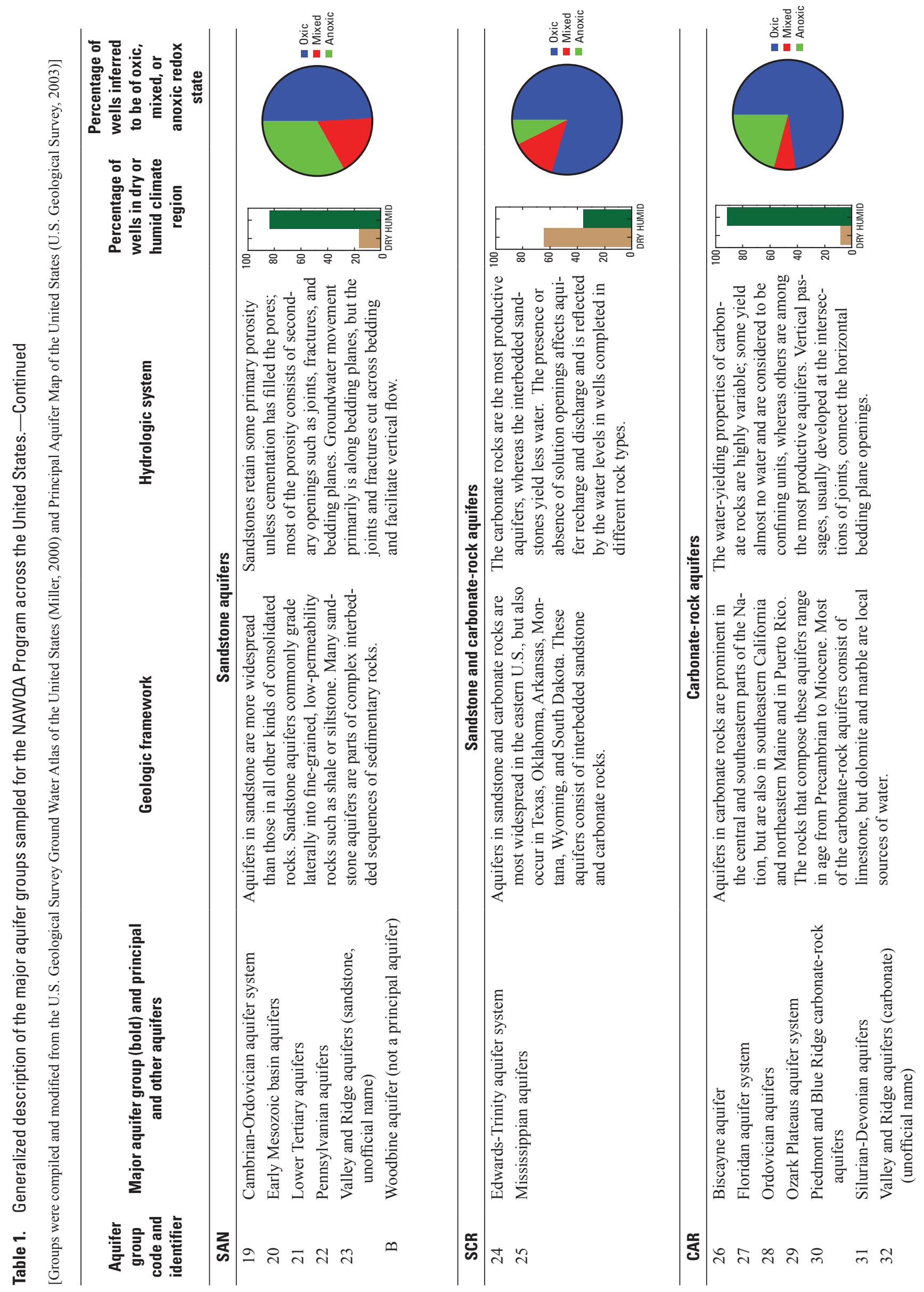




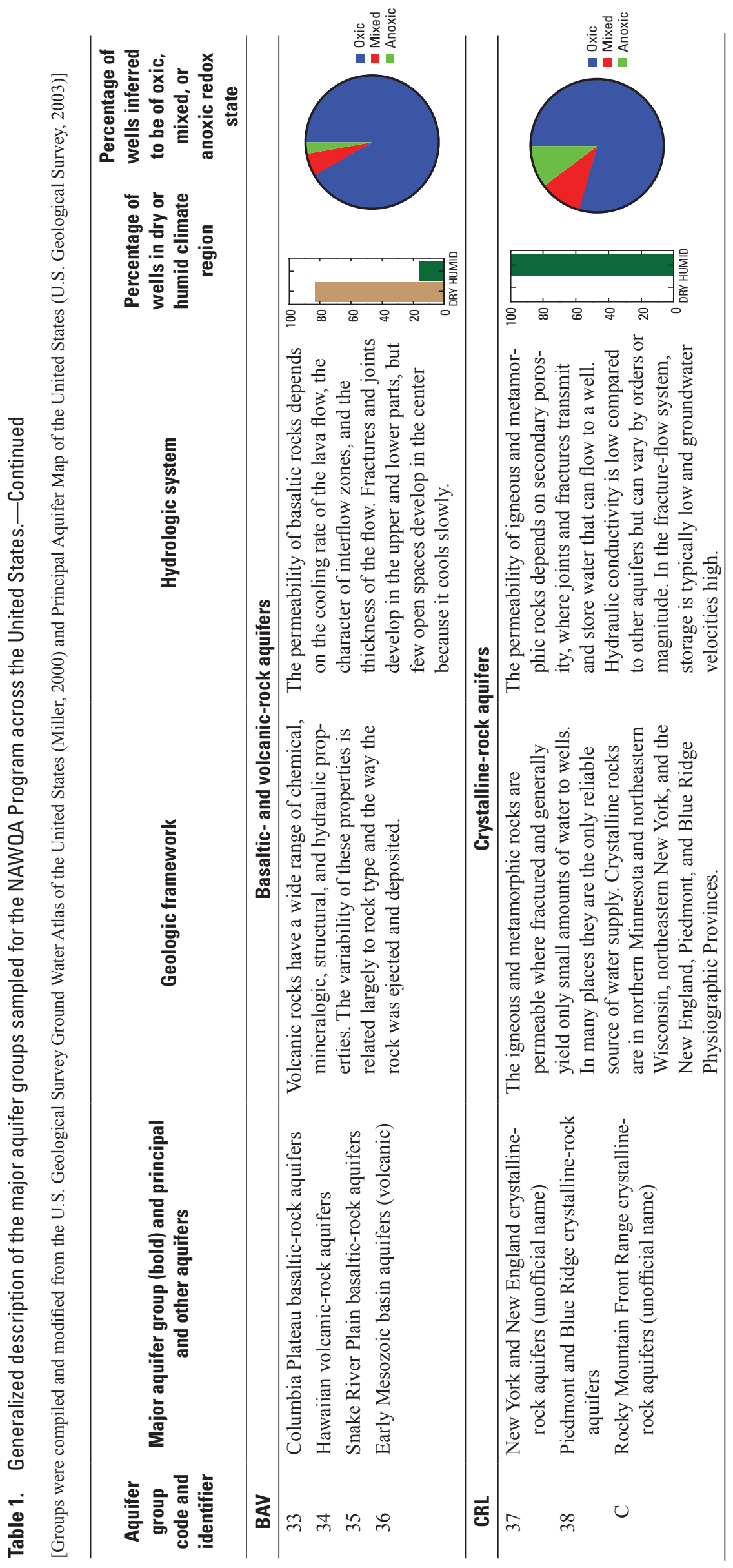




\section{Chemical Evolution and Groundwater Age}

The geochemistry of groundwater evolves over time in large part because of contact with aquifer materials. Groundwater is rarely in chemical equilibrium with the minerals in the aquifer through which it flows; it is constantly changing along its flow path through reactions with minerals in what has been described as chemical evolution (Plummer and Back, 1980; Hem, 1985). In general, the longer the water has been in an aquifer, the greater the concentrations of dissolved solids, and the more chemically evolved the water is considered to be. Chemical evolution also may be affected by factors other than age (which is related to the rate of flow of groundwater through an aquifer). Factors that affect chemical evolution include the geologic and geochemical composition of the aquifer, the geochemical composition of the groundwater, and biogeochemical processes in the aquifer.

Trilinear diagrams, a method for showing ratios of major cations and anions in water samples, are used to indicate water type information about samples from various aquifer groups in this report. Trilinear diagrams have been used successfully to assess water type and infer chemical evolution (Hanshaw and Back, 1979; Back and others, 1988; Drever, 1988; Rogers, 1989; Hem, 1985; Welch and Lico, 1998).

The occurrence of many trace elements in groundwater is related to the length of time that the water has been in contact with the soil and underlying aquifer materials - that is, the time elapsed since recharge. Measurement of the time water is in an aquifer (apparent age of the water) is complicated by the potential mixing of waters of different ages. For wells with short open intervals, like many monitoring wells, the effects of mixing may be minimized. Groundwater samples that were collected by the NAWQA Program for age dating were analyzed for several constituents, including, tritium-helium, and CFCs (Plummer and others, 1993). In this report, only samples that were analyzed for tritium (number of samples $(N)$ equal to 1,932 ) were used to estimate the age of groundwater.

The most basic use of tritium analysis in groundwater is to indicate whether it is present at measurable concentrations in the water sample; if it is, at least some of the water in the sample postdates the advent of nuclear testing in about 1953 (Plummer and others, 1993). Groundwater samples recharged after 1953 are defined as "young" waters, and those recharged before 1953 are defined as "old". Concentrations of tritium in recharge water derived entirely from precipitation prior to nuclear testing are estimated to have been less than about 0.2 to 0.8 tritium units (TU) $(0.65$ to $2.6 \mathrm{pCi} / \mathrm{L})$ by the early 1990s (Plummer and others, 1993) and about 0.12 to $0.5 \mathrm{TU}$ (about 0.39 to $1.6 \mathrm{pCi} / \mathrm{L}$ ) by the early $2000 \mathrm{~s}$ (Rupert and Plummer, 2005). In this report, the presence of tritium above the common reporting limit of $2.5 \mathrm{pCi} / \mathrm{L}$ was considered to indicate that at least some young groundwater was present in the sample. Groundwater samples with tritium activities less than or equal to $2.5 \mathrm{pCi} / \mathrm{L}$ are interpreted as containing water predominantly recharged before 1953 .

\section{Redox and $\mathrm{pH}$}

Other factors, such as redox status or $\mathrm{pH}$, may have a controlling effect on trace-element concentrations despite the degree of chemical evolution of the water sample. Methods for inferring redox state from commonly measured chemical constituents, including concentrations of DO, may provide a useful context for evaluating trace-element occurrence on a national and regional scale. Redox is a measure of the oxidation-reduction state of the groundwater, which in natural systems can be measured by the hierarchical progression of terminal electron acceptors for the reduction of compounds in groundwater (Froelich and others, 1979; Chapelle and others, 1995; Chapelle and others, 2002; Paschke, 2007; McMahon and Chapelle, 2008; McMahon and others, 2009). Redox conditions for the water in each well in this analysis were determined from a scheme that evaluates concentrations of DO, nitrate, Mn, Fe, and sulfate, and methane (Paschke, 2007; McMahon and Chapelle, 2008). For this study, redox was generalized into three categories: (1) groundwater that was $\mathrm{O}_{2}$ or nitrate-reducing was considered generally oxic; (2) groundwater that was $\mathrm{Mn}(\mathrm{IV})$ reducing, Fe(III)/sulfate-reducing, or methanogenic was considered generally anoxic; and (3) groundwater without a distinct redox signal, or for which more than one redox process criterion was met, was considered mixed. Water samples used in this study from dry climates have redox conditions that are generally oxic, whereas humid-region samples are more often anoxic (fig. 2A). The generalized redox classification and results for wells in this study are presented in table 2 .

Groundwater $\mathrm{pH}$ is another important geochemical control that can affect the solubility and mobility of trace metals, often through sorption/desorption processes (Drever, 1988; Welch and Stollenwerk, 2003; Paschke, 2007). For many metals, such as $\mathrm{Al}, \mathrm{Cu}, \mathrm{Fe}, \mathrm{Mn}$, and $\mathrm{Zn}$, solubility in water often decreases with increasing $\mathrm{pH}$. For others, such as As and $\mathrm{U}$, solubility can increase with increasing $\mathrm{pH}$ over the normal $\mathrm{pH}$ range of most natural waters. Thus, consideration of $\mathrm{pH}$ along with redox conditions is important to the overall distribution of trace elements in groundwater. For this analysis, samples are grouped into two categories: less than 7 (low $\mathrm{pH}$ ) and greater than or equal to 7 (high $\mathrm{pH}$ ), based on the midpoint of the $\mathrm{pH}$ scale and the control of reactions involving trace elements by processes that predominate at $\mathrm{pH}$ values either smaller or greater than 7 . 

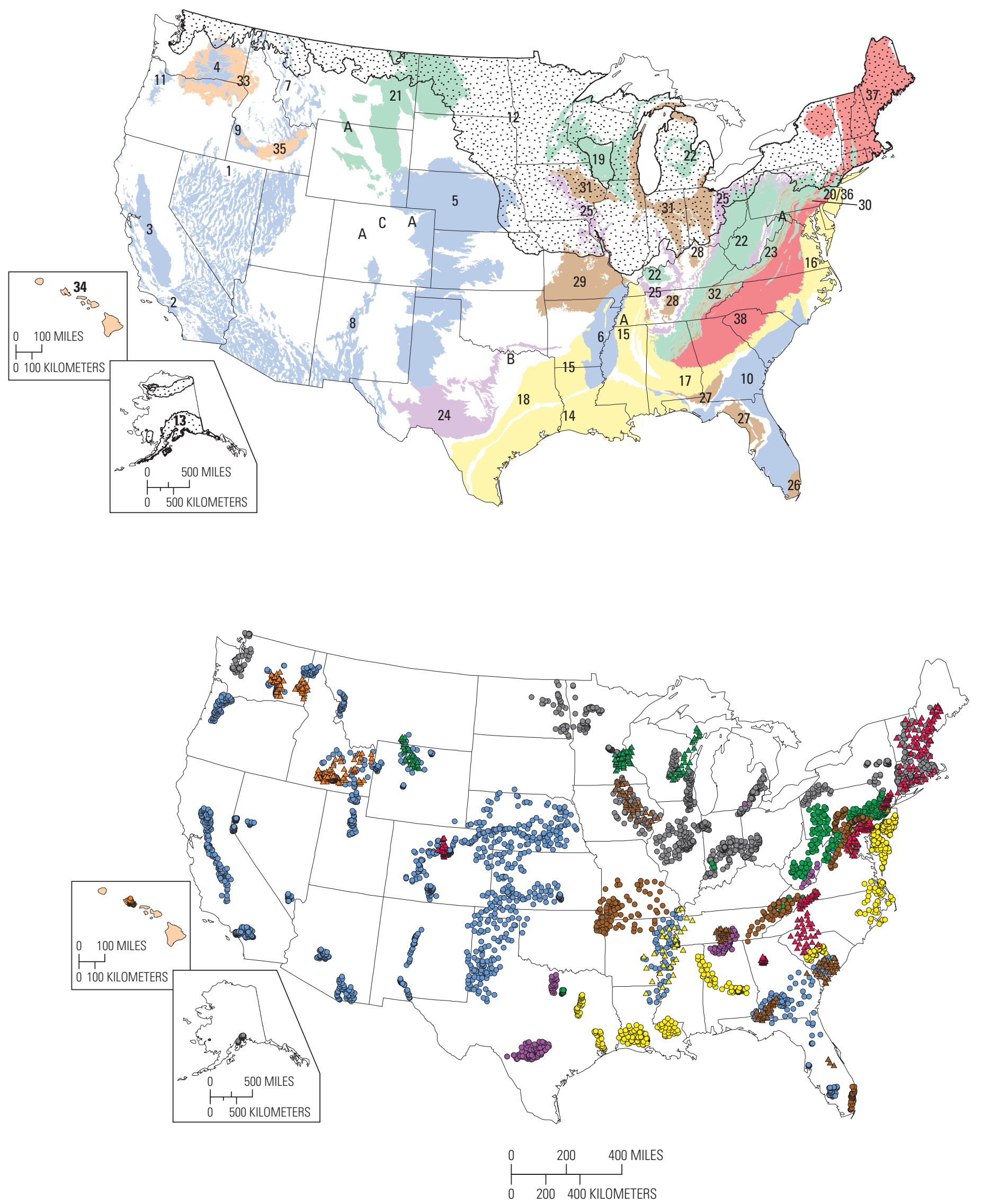

Figure 3. (A) Principal aquifers of the United States and major aquifer groups used in the current study, and $(B)$ wells sampled by the National Water-Quality Assessment Program, 1992-2003, color coded by aquifer (see explanation). Areal extent of aquifers from U.S. Geological Survey (2003). 


\section{EXPLANATION}

Aquifers and well locations-Aquifers are shown by major aquifer group (colored areas) and are identified by number. Well location is shown by colored circles (colored triangles if the well is completed in the material beneath the uppermost aquifer).

Unconsolidated sand and gravel aquifers

- 1 Basin and Range basin-fill aquifers

- 2 California Coastal Basin aquifers

- 3 Central Valley aquifer system

- 4 Columbia Plateau basin-fill aquifers

- 5 High Plains aquifer

- 6 Mississippi River Valley alluvial aquifer

- 7 Northern Rocky Mountains Intermontane Basins aquifer system

- 8 Rio Grande aquifer system

- 9 Snake River Plain basin-fill aquifers

- 10 Surficial aquifer system

- 11 Willamette Lowland basin-fill aquifers

- A stream valley aquifers (not a principal aquifer)

Glacial unconsolidated sand and gravel aquifers

- 12. Glacial aquifer system

- 13: Unconsolidated-deposit aquifers (Alaska)

\section{Semiconsolidated sand aquifers}

- 14 Coastal lowlands aquifer system

$\triangle 15$ Mississippi embayment aquifer system

- 16 Northern Atlantic Coastal Plain aquifer system

- 17 Southeastern Coastal Plain aquifer system

- 18 Texas coastal uplands aquifer system

Sandstone aquifers

4 19 Cambrian-Ordovician aquifer system

- 20 Early Mesozoic basin aquifers

\ 21 Lower Tertiary aquifers

- 22 Pennsylvanian aquifers

- 23 Valley and Ridge aquifers (sandstone)

- B Woodbine aquifer (not a principal aquifer)

\section{Sandstone and carbonate-rock aquifers}

- 24 Edwards-Trinity aquifer system

- 25 Mississippian aquifers

Carbonate-rock aquifers

- 26 Biscayne aquifer

\ 27 Floridan aquifer system

\28 Ordovician aquifers

- 29 Ozark Plateaus aquifer system

- 30 Piedmont and Blue Ridge carbonate-rock aquifers

$\Delta 31$ Silurian-Devonian aquifers

- 32 Valley and Ridge aquifers (carbonate)

Basaltic- and other volcanic-rock aquifers

$\triangle 33$ Columbia Plateau basaltic-rock aquifers

- 34 Hawaiian volcanic-rock aquifers

$\triangle 35$ Snake River Plain basaltic-rock aquifers

$\Delta 36$ Early Mesozoic basin aquifers (volcanic)

Crystalline-rock aquifers

- 37 New York and New England crystalline-rock aquifers (unofficial name)

\38 Piedmont and Blue Ridge crystalline-rock aquifers

$\Delta$ C Rocky Mountain Front Range crystalline-rock aquifers (unofficial name)

Figure 3. (A) Principal aquifers of the United States and major aquifer groups used in the current study, and (B) wells sampled by the National Water-Quality Assessment Program, 1992-2003, color coded by aquifer (see explanation). Areal extent of aquifers from U.S. Geological Survey (2003)._-Continued 
Table 2. Threshold concentrations for classification of generalized groundwater redox conditions and number of samples collected for the NAWQA Program across the United States by pH category, 1992-2003.

$\left[<\right.$, less than; $\geq$, greater than or equal to; $\mathrm{mg} / \mathrm{L}$, milligrams per liter; $\mathrm{O}_{2}$, oxygen; $\mathrm{NO}_{3} ;$, nitrate; $\mathrm{Mn}$, manganese; $\mathrm{Fe}$, iron; $\mathrm{SO}_{4}{ }^{2-}$, sulfate; >, greater than; $\leq$, less than or equal to; --, not applicable]

\begin{tabular}{|c|c|c|c|c|c|c|c|}
\hline \multirow{2}{*}{ Reduction process } & \multicolumn{2}{|c|}{ Number of samples } & \multicolumn{5}{|c|}{$\begin{array}{c}\text { Criteria } \\
\text { (mg/L) }\end{array}$} \\
\hline & $\mathrm{pH}<7$ & $\mathrm{pH} \geq 7$ & $\mathrm{O}_{2}$ & $\mathrm{NO}_{3}^{-}$ & $\begin{array}{l}\text { Mn, } \\
\text { total }\end{array}$ & $\begin{array}{c}\mathrm{Fe}, \\
\text { total }\end{array}$ & $\mathrm{SO}_{4}{ }^{2-}$ \\
\hline \multicolumn{8}{|c|}{ Oxic } \\
\hline $\mathrm{O}_{2}$ & 949 & 1,764 & $>0.5$ & $>0.5$ & $\leq 0.05$ & $\leq 0.1$ & -- \\
\hline $\mathrm{NO}_{3}^{-}$ & 46 & 264 & $\leq 0.5$ & $>0.5$ & $\leq 0.05$ & $\leq 0.1$ & -- \\
\hline \multicolumn{8}{|c|}{ Mixed } \\
\hline Mixed & 495 & 420 & \multicolumn{5}{|c|}{ Multiple criteria met } \\
\hline \multicolumn{8}{|c|}{ Anoxic } \\
\hline $\mathrm{Mn}$ & 32 & 113 & $\leq 0.5$ & $\leq 0.5$ & $>0.05$ & $\leq 0.1$ & -- \\
\hline $\mathrm{Fe} /$ high $\mathrm{SO}_{4}^{2-}$ & 250 & 359 & $\leq 0.5$ & $\leq 0.5$ & $>0.05$ & $>0.1$ & $>4$ \\
\hline $\mathrm{Fe} /$ low $\mathrm{SO}_{4}^{2-}$ & 63 & 116 & $\leq 0.5$ & $\leq 0.5$ & $>0.05$ & $>0.1$ & $\leq 4$ \\
\hline Total & 1,835 & 3,036 & & & & & \\
\hline
\end{tabular}

\section{Data Handling and Statistical Methods}

Trace-element data used in this report were retrieved from the USGS NAWQA data warehouse in 2006 (Bell and Williamson, 2006). The NAWQA data warehouse contains water-quality data, field parameters, and ancillary information for all groundwater sites sampled as part of the NAWQA Program. The original data also are available at http://water. usgs.gov/nawqa/data. The trace-element dataset includes 5,183 sites; however, the number of trace elements analyzed differs from site to site.

A large proportion of the trace-element and other waterchemistry data were censored at various LRLs. The censoring level for each trace element and Rn was adjusted to the respective Long Term Method Detection Limit (LT-MDL; a value that is usually one-half the LRL), thus providing a lower reporting level for each element (Childress and others, 1999). For this report, data censored to the LT-MDL were used for distributional data summaries; the censored data are available with this report (at http://water.usgs.gov/nawqa/trace/pubs/ sir2011-5059). Because LRLs change over time, multiple reporting levels have been defined for many trace elements. For this report, the data were recensored to the most common reporting level for each trace element to allow comparisons among data from different groups. The common reporting level was $1 \mu \mathrm{g} / \mathrm{L}$ for most trace elements and $80 \mathrm{pCi} / \mathrm{L}$ for $\mathrm{Rn}$. Reporting levels for B, Fe, and $\mathrm{Sr}$ were 12, 10, and $0.9 \mu \mathrm{g} / \mathrm{L}$, respectively. Statistical analyses were based on all data values, including censored data. Maps were used to show the geographic distribution for all trace elements.

Summary statistics, which include the minimum, maximum, and common percentiles, were computed for all trace elements by using regression-on-order statistics (ROS) statistics appropriate for data with a large proportion (up to 80 percent) of censored values (Helsel and Hirsch, 1992; Helsel, 2005). Data summaries that refer to the proportion of samples with concentrations above specified common reporting levels are not affected by the recensoring because the reporting levels are equal to or greater than the LT-MDLs.

Nonparametric statistics, which do not require distributional assumptions about the censored data, were used to describe distributions or compare data among groups. The Wilcoxon and Kruskal-Wallis tests were used to determine whether the distributions of the data from two or more groups were significantly different (Helsel and Hirsch, 1992; SAS Institute, 1999; Helsel, 2005). If multiple-comparison tests indicated significant differences, the Tukey test was used on the ranks of the data to identify which group means were significantly different (Helsel and Hirsch, 1992; SAS Institute, 1999; Helsel, 2005). Although other methods are available for comparing groups, such as substitution and distributional methods (Helsel, 2005), nonparametric methods offer several benefits, including no assumption of normally distributed data; good statistical power; and the use of data below the censoring 
level without having to create values for them, resulting in an accurate portrayal of the censored information (Helsel and Hirsch, 1992; Helsel, 2005). Spearman correlation coefficients (rho) were computed to measure the strength of the relation between environmental factors (ancillary data) and concentrations of selected trace elements (Helsel and Hirsch, 1992). The significance level $(\alpha)$ for all statistical tests was equal to 0.05 . Thus, for $p$-values less than 0.05 , the null hypothesis can be rejected in favor of the alternate hypothesis.

Logistic regression was used to help identify processes and factors affecting trace-element concentrations in groundwater for each aquifer group. For logistic regression methods, the dependent variable is a binary response variable, and the regression model predicts the probability of an event outcome, or the probability that a response is observed. In this way, logistic regression models can be used with data that are highly censored without violating assumptions about the distribution of the data (Helsel, 2005). Independent variables were either continuous or binary variables. For logistic regression models, common reporting levels and HHBs for selected trace elements were used as cut points for binary dependent and independent variable development, unless otherwise noted. Models were evaluated by consideration of the Hosmer-Lemeshow goodness of fit (Hosmer and Lemeshow, 2000). Higher $p$-values indicate better fit because the null hypothesis is that the model fits the data. Also model discrimination was evaluated with the $c$ statistic, which is an estimate of the area under the receiver operating characteristic curve - values greater than 0.7 are considered acceptable, and values greater than 0.8 are considered excellent (Hosmer and Lemeshow, 2000).

All statistical tests and models were computed by SAS System software (SAS Institute, 1999). Statistical summaries were computed by robust ROS methods (Helsel, 2005) by using a SAS macro for such a method (Practical Stats, 2007).

\section{Quality Control}

As part of the quality control (QC) for groundwater samples collected by the NAWQA Program, additional samples were collected and analyzed to determine if the measured concentrations of trace elements were representative of environmental concentrations and were reproducible. Two primary types of QC samples for evaluation of the environmental data included blanks and replicates. Blanks are samples of water free of constituents of interest, are collected prior to collection of an environmental sample, and indicate if trace elements were introduced to the QC sample (and by association, the environmental sample) during collection, handling, or analysis. Replicates are also collected sequentially after the environmental sample and indicate variability in reported results for a given constituent. The analysis of blank samples was performed by using analytical methods with detection limits at or below those for the environmental samples (Apodaca and others, 2006).
Potential sample contamination levels, at the 95-percent confidence level, were determined from the blank data for each trace element (Apodaca and others, 2006). For a given trace element, the percentages of blank concentrations greater than the common reporting levels used in this report were used to evaluate the possible effects of contamination on the dataset. The results of the trace-element-blank analysis indicate that $\mathrm{Sb}, \mathrm{Be}, \mathrm{Mo}$, and $\mathrm{Tl}$ in groundwater were largely unaffected by contamination (fewer than 1 percent of samples had concentrations greater than $1 \mu \mathrm{g} / \mathrm{L}$ ) (table 3 ). Limited numbers of blanks for $\mathrm{Li}$ and $\mathrm{V}$ in groundwater did not allow for a reliable assessment of the potential contamination associated with these trace elements. Blank samples for $\mathrm{Al}$ and $\mathrm{Zn}$ had the largest potential for contamination, with 50 percent or more of blanks having concentrations greater than $1 \mu \mathrm{g} / \mathrm{L}$. In this study, a common reporting level of $12 \mu \mathrm{g} / \mathrm{L}$ was used for $\mathrm{B}$, and 15 percent of the blank samples exceeded this value (table 3 ).

Potential contamination, at the 95-percent upper confidence level, was identified in blank samples for 17 trace elements (Al, As, Ba, B, Cd, Co, Cr, Cu, Fe, Pb, Mn, Ni, Se, $\mathrm{Ag}, \mathrm{Sr}, \mathrm{U}$, and $\mathrm{Zn})$ at the common reporting levels used in this report (Apodaca and others, 2006). About 3 percent or fewer of blank samples for $\mathrm{As}, \mathrm{Cd}, \mathrm{Co}, \mathrm{Pb}, \mathrm{Ni}, \mathrm{Se}, \mathrm{Ag}$, and $\mathrm{U}$ were contaminated. Four to 10 percent of blanks for $\mathrm{Ba}, \mathrm{Cr}, \mathrm{Fe}, \mathrm{Mn}$, and $\mathrm{Sr}$ were possibly contaminated. $\mathrm{Al}, \mathrm{B}, \mathrm{Cu}$, and $\mathrm{Zn}$ were the most affected, with possible contamination detected in 15 to more than 50 percent of blank samples (table 3).

Contamination of samples can also be viewed in terms of its effect on evaluation of samples exceeding HHBs or nonhealth guidelines. The contamination levels for most of the trace elements reported here are at concentrations that are less than 10 percent of HHBs or nonhealth-guideline concentrations; therefore, potential contamination of samples would not affect the comparison of concentrations of trace elements in groundwater with benchmarks or guidelines (Apodaca and others, 2006). The exceptions are possibly $\mathrm{Al}, \mathrm{Cd}$, and $\mathrm{Pb}$. Potential contamination identified for these trace elements is greater than 10 percent of the HHBs or nonhealth guidelines, but affects only 5 percent or fewer of the $\mathrm{Cd}$ and $\mathrm{Pb}$ samples. For most trace elements, the level of potential contamination is not large enough to affect the measured concentration of the environmental sample significantly.

Replicate groundwater-sample concentration differences for all trace elements were less than 15 percent except for $\mathrm{Tl}$ (18.3 percent) and V (15.2 percent). This indicates that sampling, handling, and analysis of samples had a relatively small effect on the reported value and that reproducibility of sample concentrations was generally good (Apodaca and others, 2006).

The analysis of the QC data indicated that the potential contamination from sample processing and analysis for most trace elements of interest was small and did not significantly affect data interpretation for most elements. For this reason, all concentration data were used unaltered. 
Table 3. Summary of blank data for trace elements in groundwater sampled for the NAWQA Program, 1992-2003, across the United States.

[ $\mu \mathrm{g} / \mathrm{L}$, micrograms per liter; $\mathrm{pCi} / \mathrm{L}$, picocuries per liter for radon; UCL, upper confidence level; >, greater than; <, less than; --, no data]

\begin{tabular}{|c|c|c|c|}
\hline Element & $\begin{array}{c}\text { Number of } \\
\text { blank samples }\end{array}$ & $\begin{array}{l}\text { Common reporting } \\
\text { level used } \\
\text { in this report } \\
(\mu \mathrm{g} / \mathrm{L} \text { or } \mathrm{pCi} / \mathrm{L})\end{array}$ & $\begin{array}{l}\text { Percentage of blank samples with 95-percent UCL } \\
\text { contamination concentrations (modified from Apodaca } \\
\text { and others, 2006, table 1) equal to or exceeding common } \\
\text { reporting levels used in this report }\end{array}$ \\
\hline Aluminum & 330 & 1 & $>50$ \\
\hline Antimony & 347 & 1 & $<1$ \\
\hline Arsenic & 329 & 1 & 1 \\
\hline Barium & 344 & 1 & 7 \\
\hline Beryllium & 346 & 1 & $<1$ \\
\hline Boron & 164 & 12 & 15 \\
\hline Cadmium & 353 & 1 & 2 \\
\hline Chromium & 343 & 1 & 6 \\
\hline Cobalt & 343 & 1 & 2 \\
\hline Copper & 345 & 1 & 15 \\
\hline Iron & 423 & 10 & 10 \\
\hline Lead & 343 & 1 & 1 \\
\hline Lithium & 37 & 1 & $<8$ \\
\hline Manganese & 546 & 1 & 10 \\
\hline Molybdenum & 341 & 1 & $<1$ \\
\hline Nickel & 339 & 1 & 3 \\
\hline Radon & 0 & 80 & -- \\
\hline Selenium & 302 & 1 & 2 \\
\hline Silver & 343 & 1 & 1 \\
\hline Strontium & 186 & 0.9 & 8 \\
\hline Thallium & 151 & 1 & $<1$ \\
\hline Uranium & 368 & 1 & 1 \\
\hline Vanadium & 37 & 1 & $<8$ \\
\hline Zinc & 341 & 1 & 50 \\
\hline
\end{tabular}




\section{Occurrence of Trace Elements in Groundwater}

The occurrence of trace elements in groundwater from wells across the United States was highly variable. Concentrations of $\mathrm{Ba}, \mathrm{B}, \mathrm{Li}, \mathrm{Rn}$, and $\mathrm{Sr}$ were above their reporting levels in nearly all samples; however, as noted in the section on quality control, measured concentrations of some elements, such as $\mathrm{Al}, \mathrm{B}, \mathrm{Cu}, \mathrm{Fe}$, and $\mathrm{Zn}$, may be excessive on the basis of data from blank samples, which suggest systematic low-level bias in the dataset. Concentrations of $\mathrm{Al}, \mathrm{Ba}, \mathrm{B}, \mathrm{Cr}, \mathrm{Li}, \mathrm{Mn}, \mathrm{Ni}, \mathrm{Rn}$, $\mathrm{Sr}, \mathrm{V}$, and $\mathrm{Zn}$ exceeded the common reporting level in more than 50 percent of samples (median) compared to $\mathrm{Sb}, \mathrm{As}, \mathrm{Be}$, $\mathrm{Cd}, \mathrm{Co}, \mathrm{Cu}, \mathrm{Fe}, \mathrm{Pb}, \mathrm{Mo}, \mathrm{Se}, \mathrm{Ag}, \mathrm{Tl}$, and $\mathrm{U}$, which were equal to or above their common reporting level in fewer than 50 percent of samples (table 4). As, B, Mn, Mo, Rn, Sr, and U occurred at concentrations greater than HHBs in more than 1 percent of water samples, and $\mathrm{Fe}$ and $\mathrm{Mn}$ occurred at concentrations greater than nonhealth guidelines in 19 and 31 percent of water samples, respectively (table 4).

Most trace elements (particularly common oxyanion or ion-complex forming elements) occurred in greater concentrations in dry regions than in humid regions (table 5). This was true for $\mathrm{As}, \mathrm{Ba}, \mathrm{B}, \mathrm{Cr}, \mathrm{Cu}, \mathrm{Li}, \mathrm{Mo}, \mathrm{Ni}, \mathrm{Se}, \mathrm{Sr}, \mathrm{U}, \mathrm{V}$, and $\mathrm{Zn}$ (tables 5 and 6; figs. 4 and 5). In contrast, concentrations of elements that are mobile in anoxic and (or) low-pH groundwater conditions (such as $\mathrm{Al}, \mathrm{Co}, \mathrm{Fe}, \mathrm{Mn}$, and $\mathrm{Pb}$ ) are commonly greater in the humid regions than in the dry regions (tables 5 and 6; figs. 4 and 5). These large-scale differences may reflect several processes, including differences in precipitation, the effects of irrigation, ion competition, complexation, redox, and evaporative concentration in the dry parts of the United States. Processes associated with dry climates, especially in conjunction with irrigation, can lead to characteristically high concentrations of total dissolved solids (TDS) in groundwater (Hem, 1985; Seiler and others, 2003; Anning and others, 2007).

\section{Trace-Element Occurrence and Concentrations in Monitoring and Drinking-Water Wells}

Well-specific factors, such as depth and type in addition to specific land uses, can influence concentrations of trace elements in groundwater. The concentrations of trace elements were compared among monitoring wells in areas representing primarily agricultural or urban land uses and drinking-water wells, by climate region (table 7).

In humid regions, 14 trace elements had greater concentrations in monitoring wells than in drinking-water wells; however, only $\mathrm{Cu}, \mathrm{Pb}, \mathrm{Rn}$, and $\mathrm{Zn}$ concentrations were greater in drinking-water wells than in monitoring wells in humid regions (table 7). Concentrations of trace elements commonly associated with low-pH recharge and (or) oxic groundwater are expected to be greater in monitoring wells (shallow wells) in humid regions than in drinking-water wells (generally deep wells). Accordingly, concentrations of Al, Sb, Ba, B, Cr, Co, $\mathrm{Fe}, \mathrm{Li}, \mathrm{Mn}, \mathrm{Mo}, \mathrm{Ni}, \mathrm{Se}, \mathrm{Sr}$, and $\mathrm{U}$ were all greater in monitoring wells than in drinking-water wells in humid regions of the United States (table 7). The greater concentrations of $\mathrm{Cu}$, $\mathrm{Pb}$, and $\mathrm{Zn}$ in drinking-water wells in humid regions (and $\mathrm{Pb}$ and $\mathrm{Zn}$ in dry regions) may be an indication that these water samples were commonly collected through existing pumps and plumbing, which can contain these metals in parts, fittings, and valves (Fahlquist and Ardis, 2004; Groschen and others, 2008). Concentrations of Fe and Mn, which occur more often in humid regions than in dry, were greater in monitoring wells than in drinking-water wells in dry climate and humid regions (table 7).

In the dry regions of the United States, concentrations of $\mathrm{As}, \mathrm{Ba}, \mathrm{Pb}, \mathrm{Li}, \mathrm{Sr}, \mathrm{V}$, and $\mathrm{Zn}$ were greater in drinkingwater wells than in monitoring wells. Some of these elements commonly form oxyanions (As, $\mathrm{Cr}$, and $\mathrm{V}$ ) under typical groundwater conditions and are soluble in oxic or anoxic alkaline environments (Smedley and Kinniburgh, 2002). For As, this may be related to the fact that $\mathrm{pH}$ values are greater in drinking-water wells in this region than in monitoring wells (table 7). 


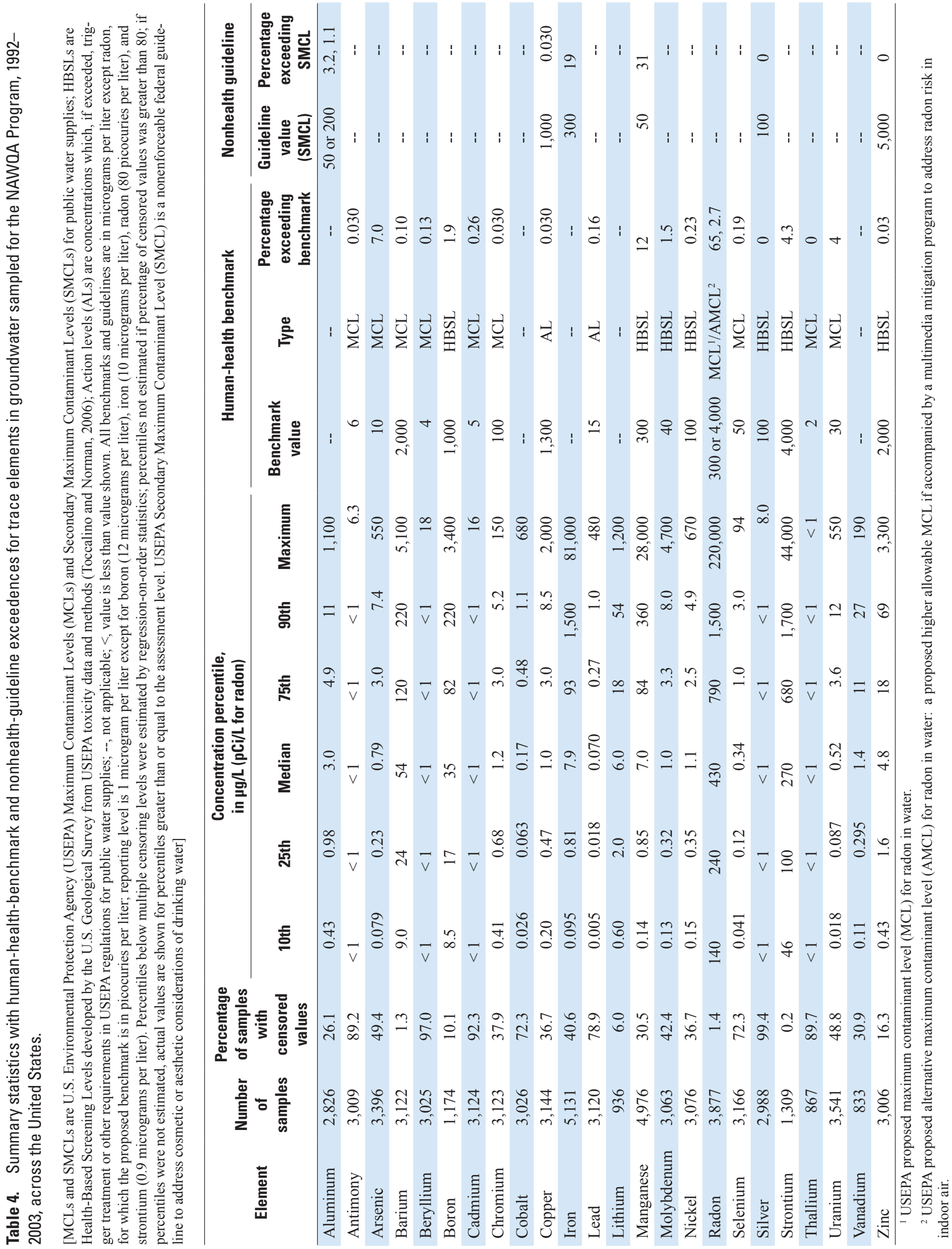




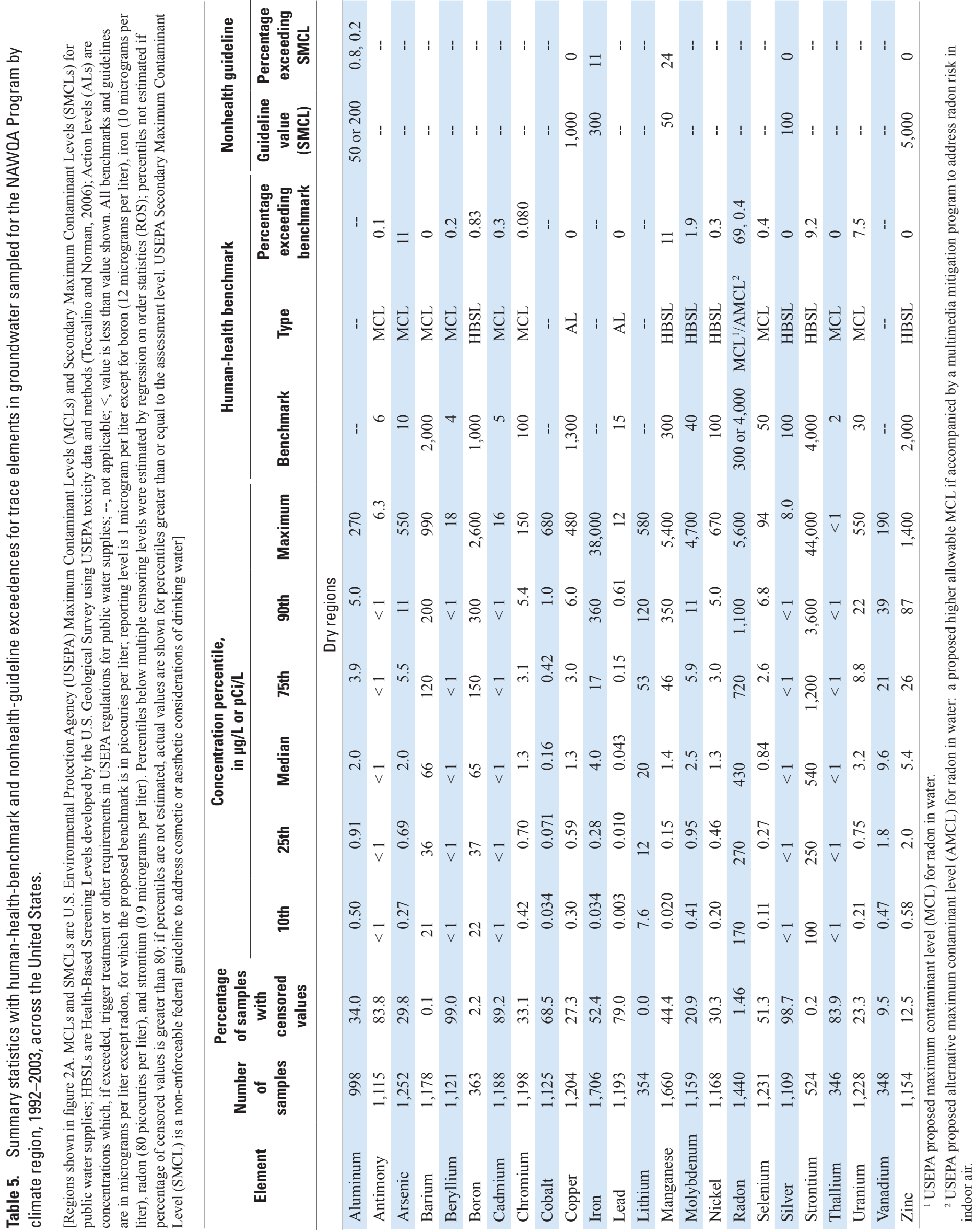




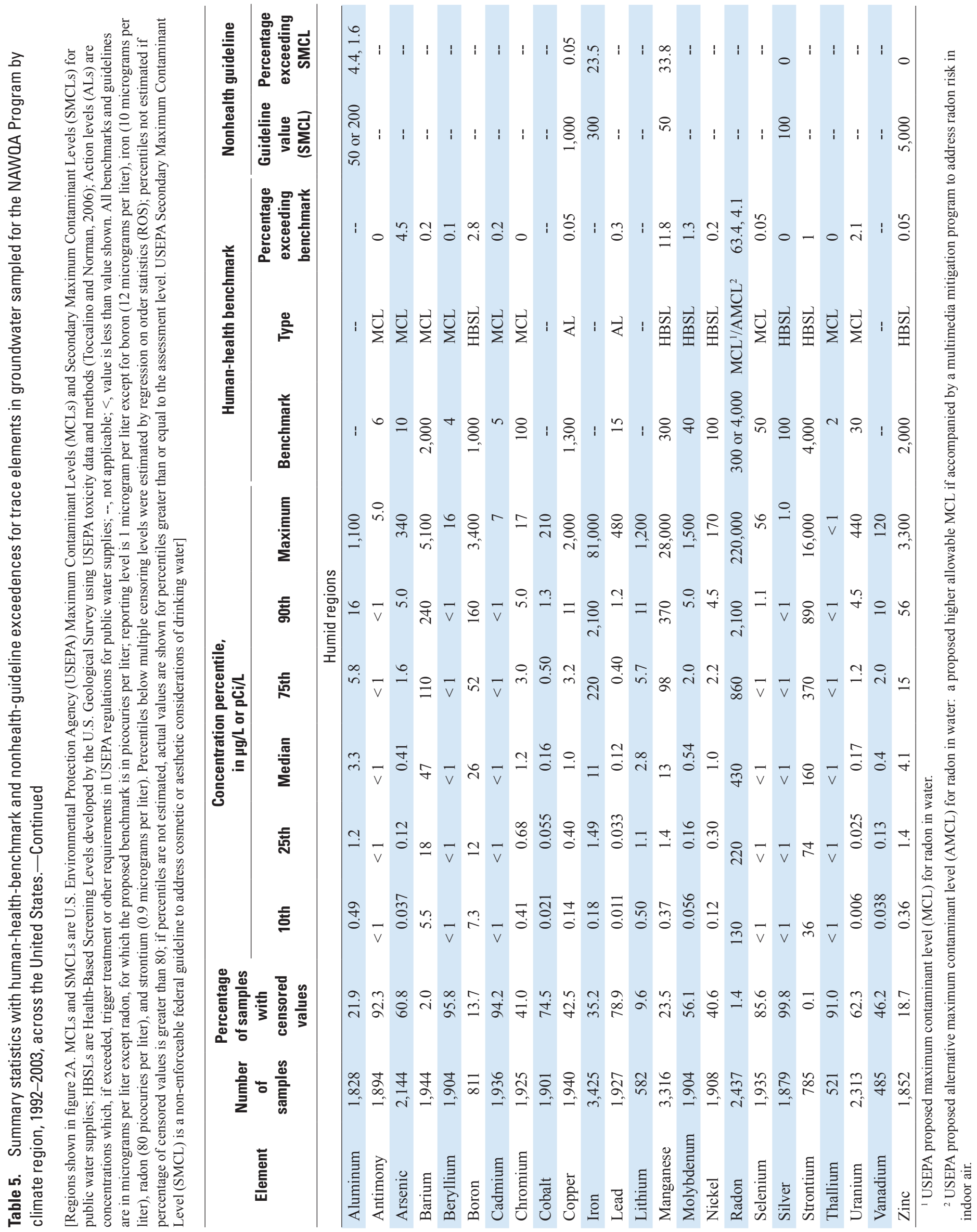


Table 6. Frequency and distribution statistics for the occurrence of trace elements in groundwater sampled for the NAWOA Program by climate region, 1992-2003, across the United States.

[Climate regions shown in figure 2A. Yellow shading indicates higher dry-region concentrations; blue shading indicates higher humid-region concentrations; concentrations of elements in same Tukey group do not differ significantly at alpha $=0.05$. No shading indicates concentrations that do not differ significantly between well types. Reporting level is 1 microgram per liter except for boron (12 micrograms per liter), iron (10 micrograms per liter), radon ( 80 picocuries per liter), and strontium ( 0.9 micrograms per liter). $\geq$, greater than or equal to; <, less than; $\mathrm{N}$ is the number of wells sampled; number of trace element samples varies with availability of grouping variable data and with censoring level]

\begin{tabular}{|c|c|c|c|c|c|c|c|}
\hline \multirow{3}{*}{ Element } & \multicolumn{7}{|c|}{ Number of samples and percentage $\geq$ reporting level by climate region } \\
\hline & \multicolumn{3}{|c|}{ Dry region } & \multicolumn{3}{|c|}{ Humid region } & \multirow{2}{*}{$p$-value } \\
\hline & $\mathbf{N}$ & Percentage & Tukey group & $\mathbf{N}$ & Percentage & Tukey group & \\
\hline Aluminum & 998 & 65 & B & 1,828 & 78 & A & $<0.0001$ \\
\hline Antimony & 1,115 & 1.0 & A & 1,894 & 1.1 & A & 0.8571 \\
\hline Arsenic & 1,252 & 67 & A & 2,144 & 34 & B & $<0.0001$ \\
\hline Barium & 1,178 & 100 & A & 1,944 & 98 & B & $<0.0001$ \\
\hline Beryllium & 1,121 & 0.4 & A & 1,904 & 0.7 & A & 0.1936 \\
\hline Boron & 363 & 97 & A & 811 & 76 & B & $<0.0001$ \\
\hline Cadmium & 1,188 & 1.3 & A & 1,936 & 0.6 & A & 0.0600 \\
\hline Chromium & 1,198 & 58 & A & 1,925 & 53 & B & 0.0148 \\
\hline Cobalt & 1,125 & 8.4 & B & 1,901 & 13 & A & 0.0004 \\
\hline Copper & 1,204 & 61 & A & 1,940 & 51 & B & 0.0272 \\
\hline Iron & 1,706 & 32 & B & 3,425 & 50 & A & $<0.0001$ \\
\hline Lead & 1,193 & 9.4 & B & 1,927 & 13 & A & 0.0015 \\
\hline Lithium & 354 & 97 & A & 539 & 78 & B & $<0.0001$ \\
\hline Manganese & 1,660 & 51 & B & 3,316 & 75 & A & $<0.0001$ \\
\hline Molybdenum & 1,159 & 74 & A & 1,904 & 39 & B & $<0.0001$ \\
\hline Nickel & 1,168 & 62 & A & 1,908 & 54 & B & $<0.0001$ \\
\hline Radon & 1,440 & 98 & A & 2,437 & 96 & A & 0.7276 \\
\hline Selenium & 1,201 & 46 & A & 1,854 & 9.7 & B & $<0.0001$ \\
\hline Silver & 1,109 & 0.6 & A & 1,879 & 0.2 & A & 0.0674 \\
\hline Strontium & 524 & 100 & A & 785 & 100 & B & $<0.0001$ \\
\hline Thallium & 346 & 0.0 & A & 521 & 0.0 & A & 1.0000 \\
\hline Uranium & 1,228 & 71 & A & 2,313 & 28 & B & $<0.0001$ \\
\hline Vanadium & 348 & 81 & A & 485 & 35 & B & $<0.0001$ \\
\hline Zinc & 1,154 & 87 & A & 1,852 & 81 & B & $<0.0001$ \\
\hline
\end{tabular}



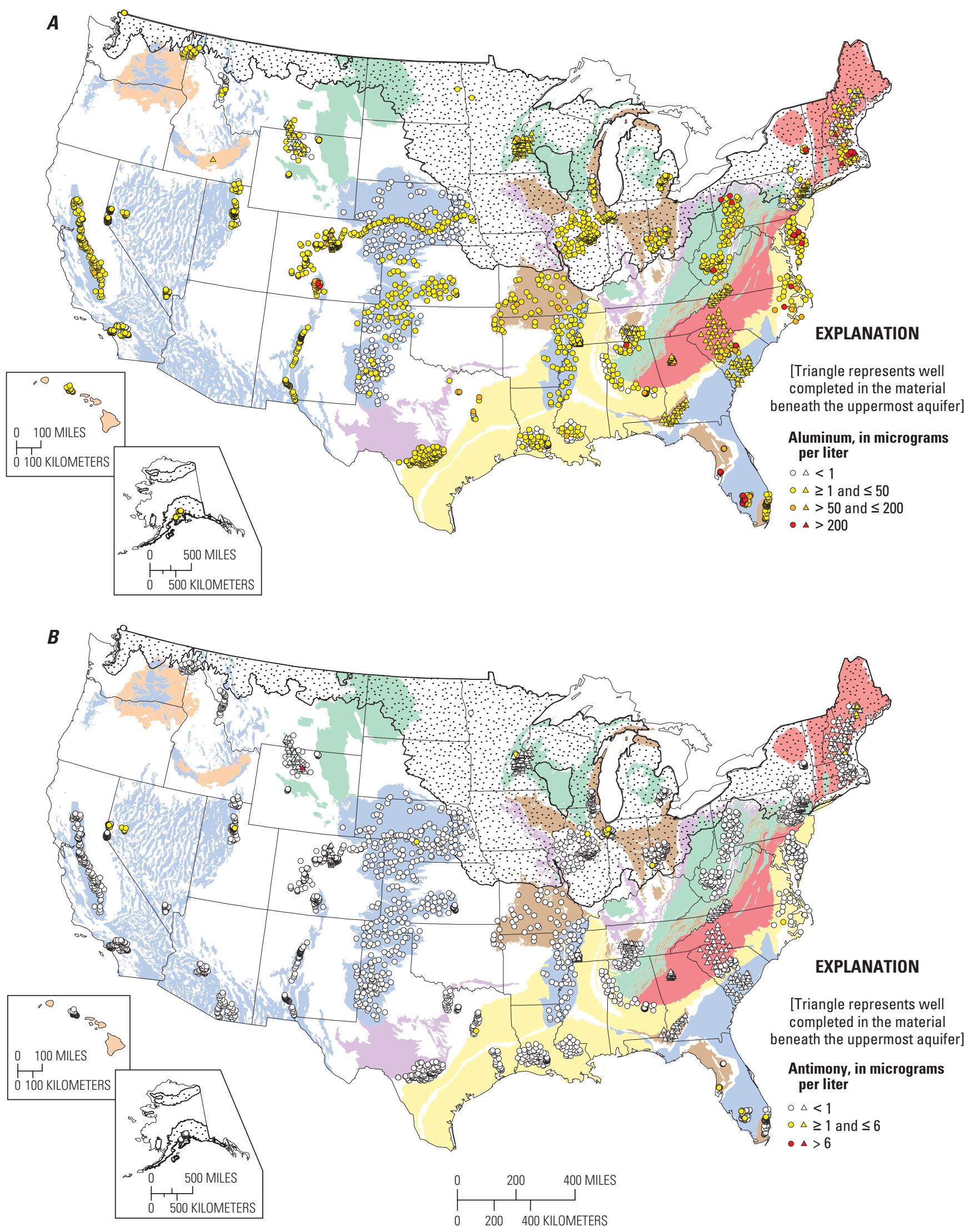

Figure 4. Geographic distribution of trace-element concentrations in groundwater collected from wells as part of the National WaterQuality Assessment Program, 1992-2003: $(A)$ aluminum, $(B)$ antimony, $(C)$ arsenic, $(D)$ barium, $(E)$ beryllium, $(F)$ boron, $(G)$ cadmium, $(H)$ chromium, (I) cobalt, $(J)$ copper, $(K)$ iron, $(L)$ lead, $(M)$ lithium, $(N)$ manganese, $(O)$ molybdenum, $(P)$ nickel, $(Q)$ radon, $(R)$ selenium, $(S)$ silver, $(T)$ strontium, $(U)$ thallium, $(V)$ uranium, $(W)$ vanadium, and $(X)$ zinc. 

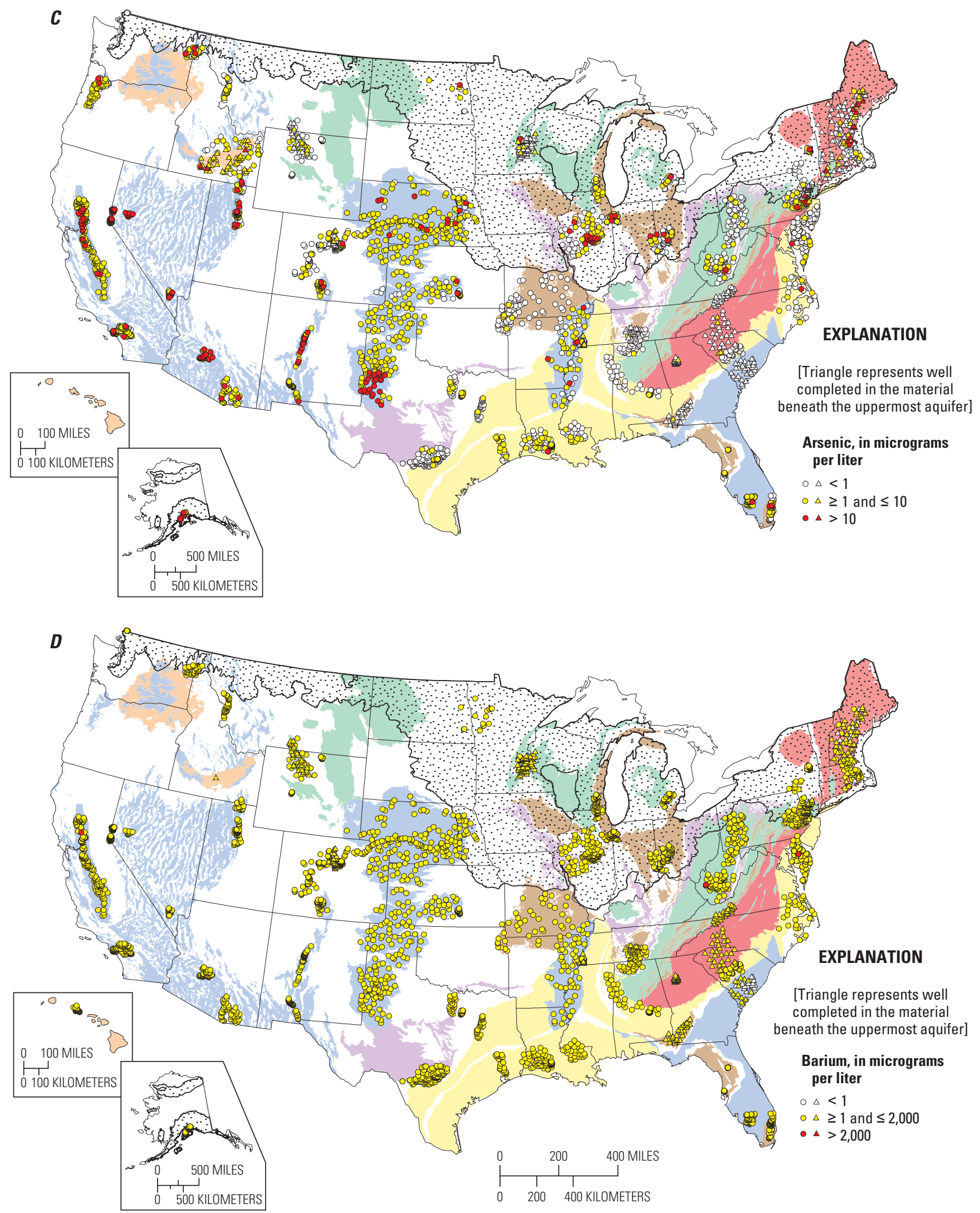

Figure 4. Geographic distribution of trace-element concentrations in groundwater collected from wells as part of the National WaterQuality Assessment Program, 1992-2003: $(A)$ aluminum, $(B)$ antimony, $(C)$ arsenic, $(D)$ barium, $(E)$ beryllium, $(F)$ boron, $(G)$ cadmium, $(H)$ chromium, (I) cobalt, (J) copper, (K) iron, (L) lead, (M) lithium, (N) manganese, (O) molybdenum, (P) nickel, (Q) radon, $(R)$ selenium, $(S)$ silver, $(T)$ strontium, $(U)$ thallium, $(V)$ uranium, $(W)$ vanadium, and $(X)$ zinc.-Continued 

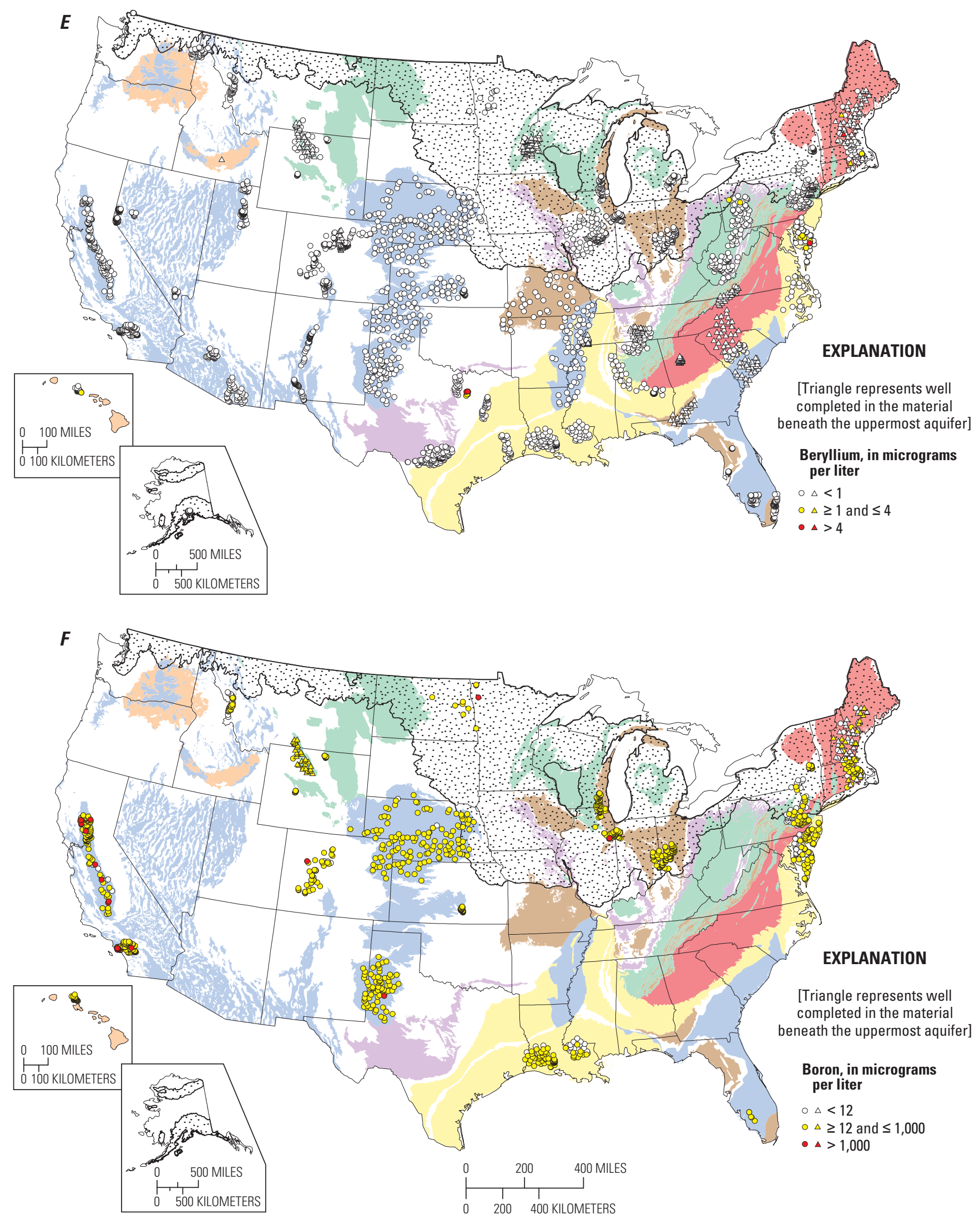

Figure 4. Geographic distribution of trace-element concentrations in groundwater collected from wells as part of the National WaterQuality Assessment Program, 1992-2003: $(A)$ aluminum, $(B)$ antimony, $(C)$ arsenic, $(D)$ barium, $(E)$ beryllium, $(F)$ boron, $(G)$ cadmium, $(H)$ chromium, (I) cobalt, $(J)$ copper, $(K)$ iron, $(L)$ lead, $(M)$ lithium, $(N)$ manganese, $(O)$ molybdenum, $(P)$ nickel, $(Q)$ radon, $(R)$ selenium, $(S)$ silver, $(T)$ strontium, $(U)$ thallium, $(V)$ uranium, $(W)$ vanadium, and $(X)$ zinc.-Continued 

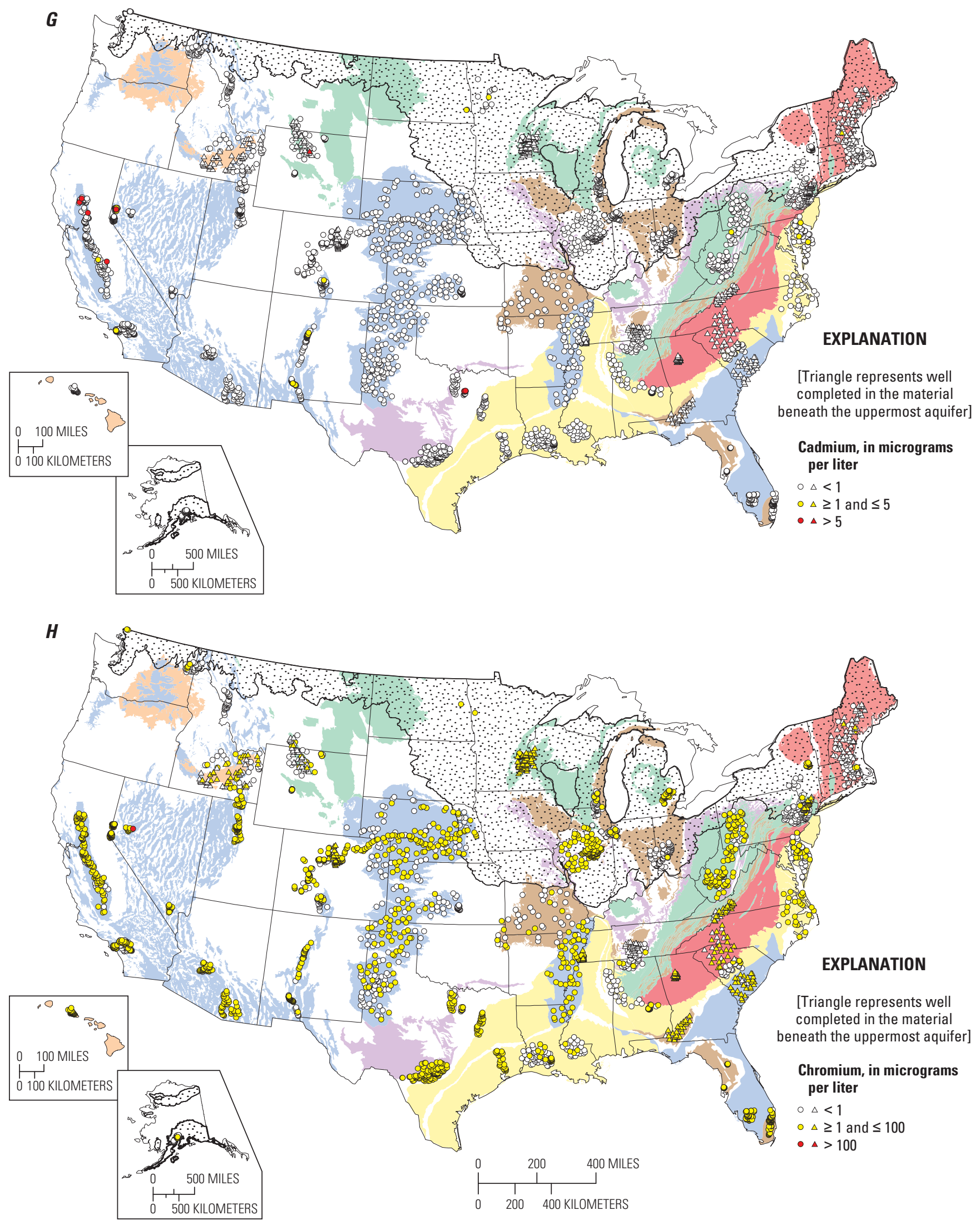

Figure 4. Geographic distribution of trace-element concentrations in groundwater collected from wells as part of the National WaterQuality Assessment Program, 1992-2003: $(A)$ aluminum, $(B)$ antimony, $(C)$ arsenic, $(D)$ barium, $(E)$ beryllium, $(F)$ boron, $(G)$ cadmium, $(H)$ chromium, (I) cobalt, (J) copper, $(K)$ iron, $(L)$ lead, $(M)$ lithium, (N) manganese, $(O)$ molybdenum, $(P)$ nickel, $(Q)$ radon, $(R)$ selenium, $(S)$ silver, $(T)$ strontium, (U) thallium, (V) uranium, (W) vanadium, and $(X)$ zinc.-Continued 

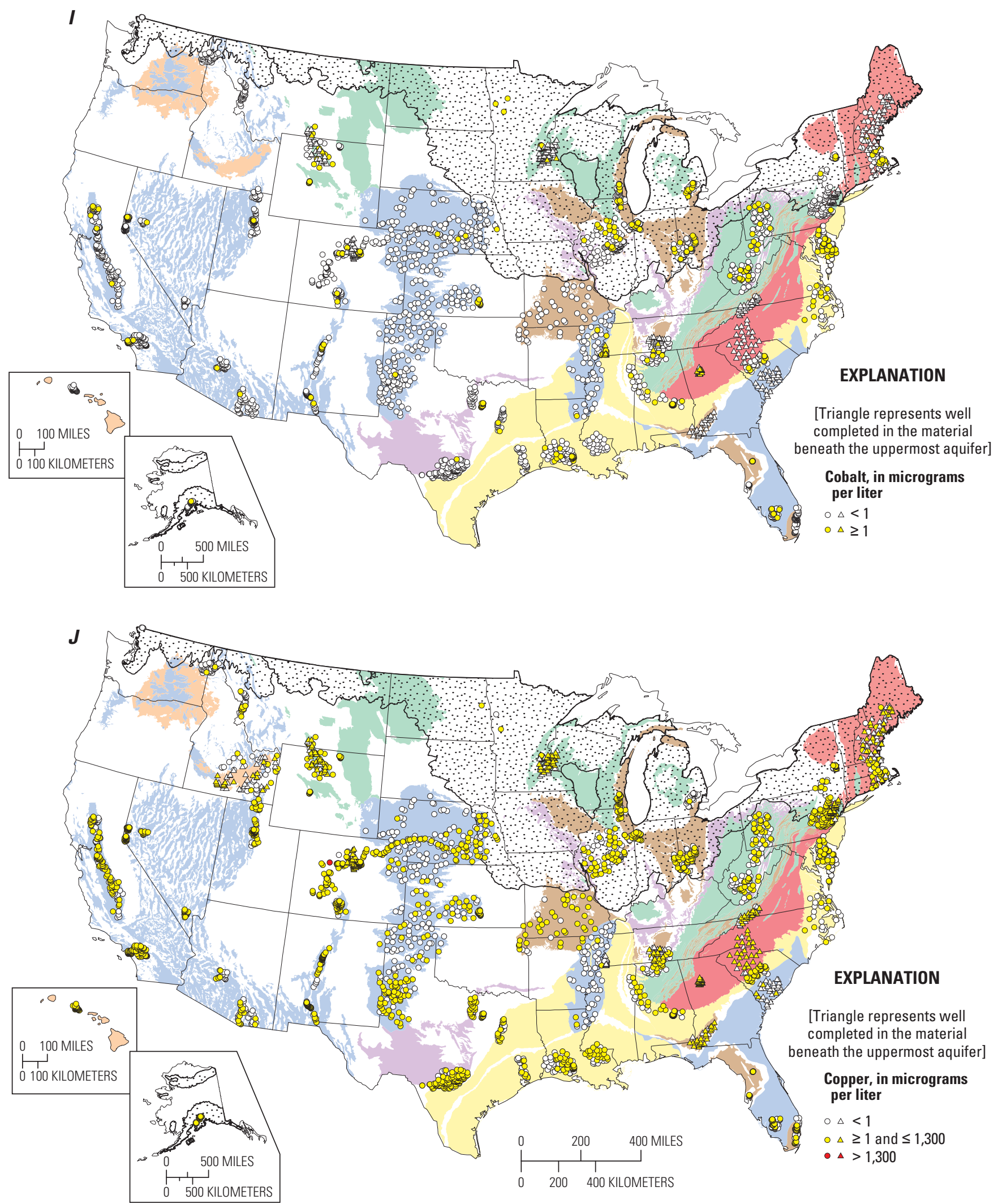

Figure 4. Geographic distribution of trace-element concentrations in groundwater collected from wells as part of the National WaterQuality Assessment Program, 1992-2003: $(A)$ aluminum, $(B)$ antimony, $(C)$ arsenic, $(D)$ barium, $(E)$ beryllium, $(F)$ boron, $(G)$ cadmium, $(H)$ chromium, (I) cobalt, (J) copper, (K) iron, (L) lead, (M) lithium, (N) manganese, (O) molybdenum, $(P)$ nickel, (Q) radon, $(R)$ selenium, $(S)$ silver, $(T)$ strontium, (U) thallium, $(V)$ uranium, $(W)$ vanadium, and $(X)$ zinc.-Continued 

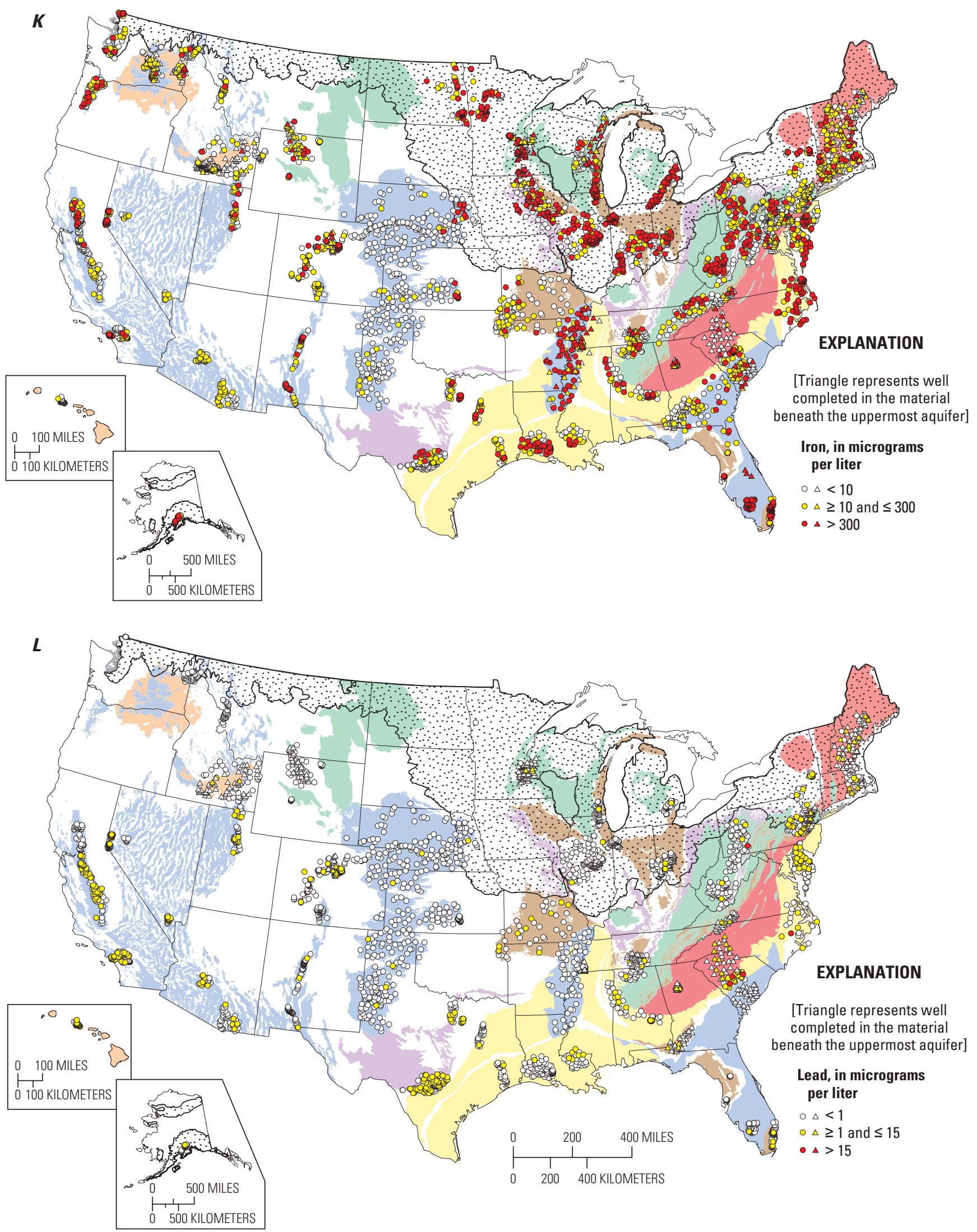

Figure 4. Geographic distribution of trace-element concentrations in groundwater collected from wells as part of the National WaterQuality Assessment Program, 1992-2003: $(A)$ aluminum, $(B)$ antimony, $(C)$ arsenic, $(D)$ barium, $(E)$ beryllium, $(F)$ boron, $(G)$ cadmium, $(H)$ chromium, (I) cobalt, $(J)$ copper, $(K)$ iron, $(L)$ lead, $(M)$ lithium, $(N)$ manganese, $(O)$ molybdenum, $(P)$ nickel, $(Q)$ radon, $(R)$ selenium, $(S)$ silver, $(T)$ strontium, (U) thallium, (V) uranium, (W) vanadium, and $(X)$ zinc.-Continued 

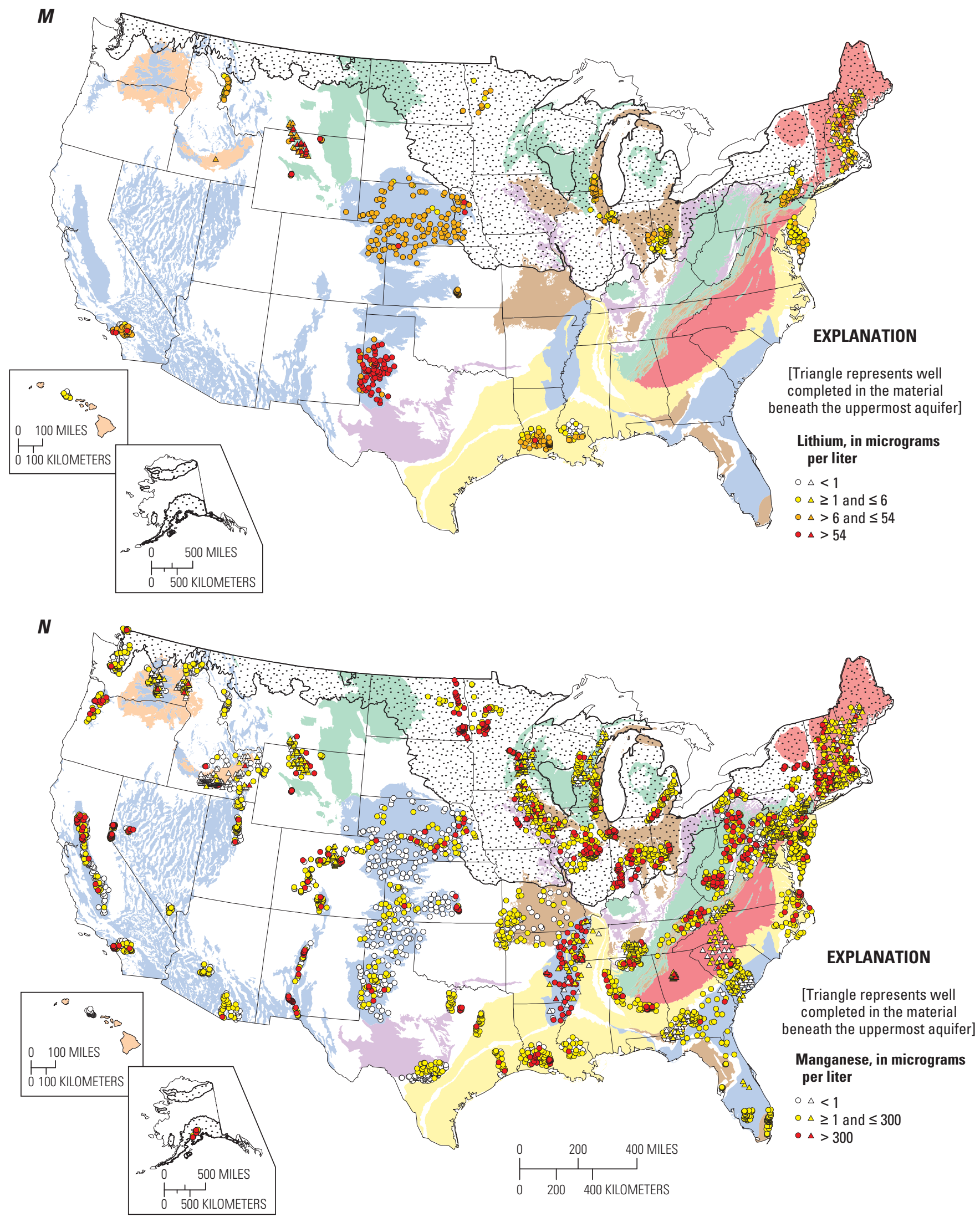

Figure 4. Geographic distribution of trace-element concentrations in groundwater collected from wells as part of the National WaterQuality Assessment Program, 1992-2003: $(A)$ aluminum, $(B)$ antimony, $(C)$ arsenic, $(D)$ barium, $(E)$ beryllium, $(F)$ boron, $(G)$ cadmium, $(H)$ chromium, (I) cobalt, $(J)$ copper, $(K)$ iron, $(L)$ lead, $(M)$ lithium, $(N)$ manganese, $(O)$ molybdenum, $(P)$ nickel, $(Q)$ radon, $(R)$ selenium, $(S)$ silver, $(T)$ strontium, $(U)$ thallium, $(V)$ uranium, $(W)$ vanadium, and $(X)$ zinc.-Continued 

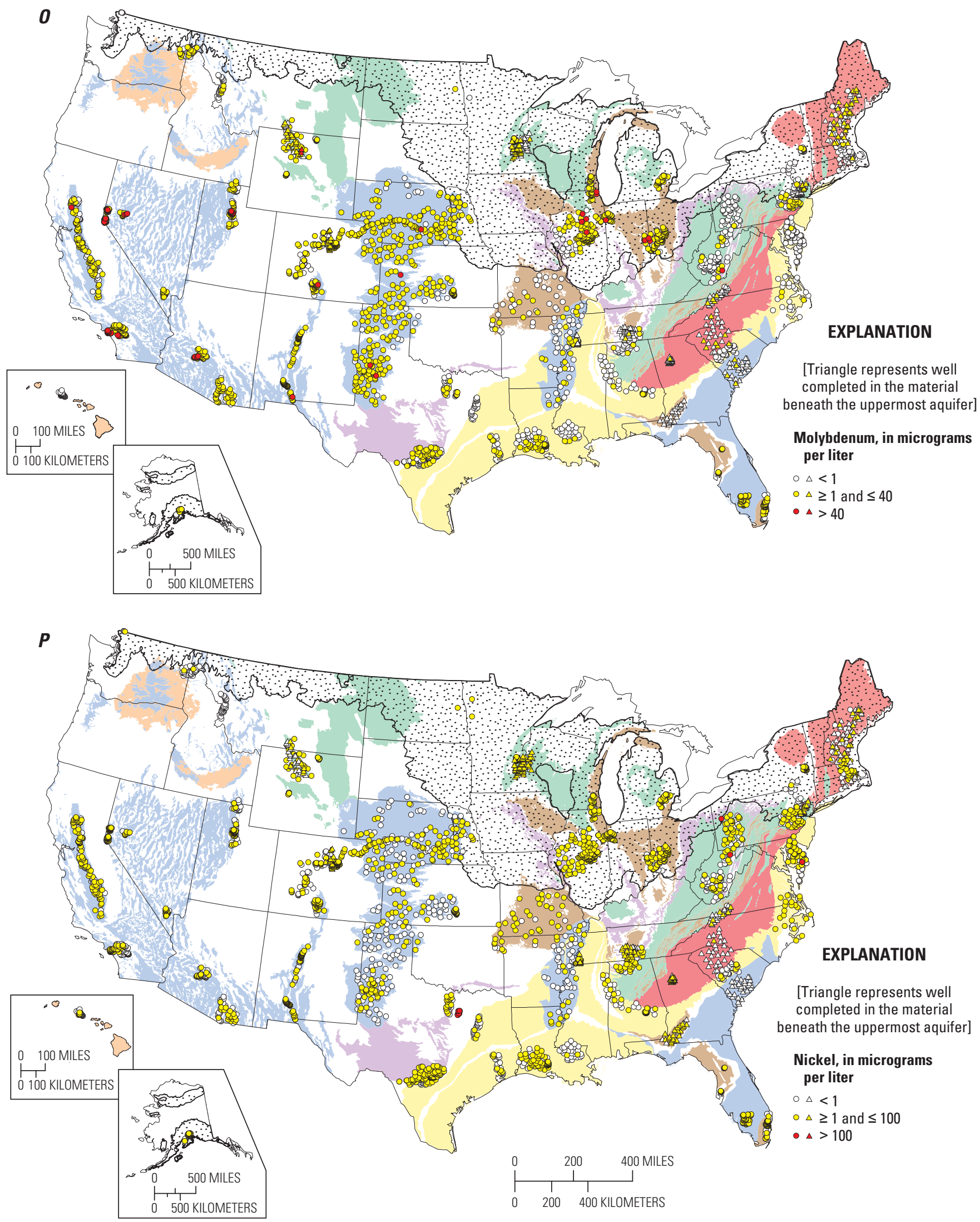

Figure 4. Geographic distribution of trace-element concentrations in groundwater collected from wells as part of the National WaterQuality Assessment Program, 1992-2003: (A) aluminum, $(B)$ antimony, $(C)$ arsenic, $(D)$ barium, $(E)$ beryllium, $(F)$ boron, $(G)$ cadmium, $(H)$ chromium, (I) cobalt, (J) copper, $(K)$ iron, $(L)$ lead, $(M)$ lithium, (N) manganese, $(O)$ molybdenum, $(P)$ nickel, $(Q)$ radon, $(R)$ selenium, $(S)$ silver, $(T)$ strontium, $(U)$ thallium, $(V)$ uranium, $(W)$ vanadium, and $(X)$ zinc.-Continued 

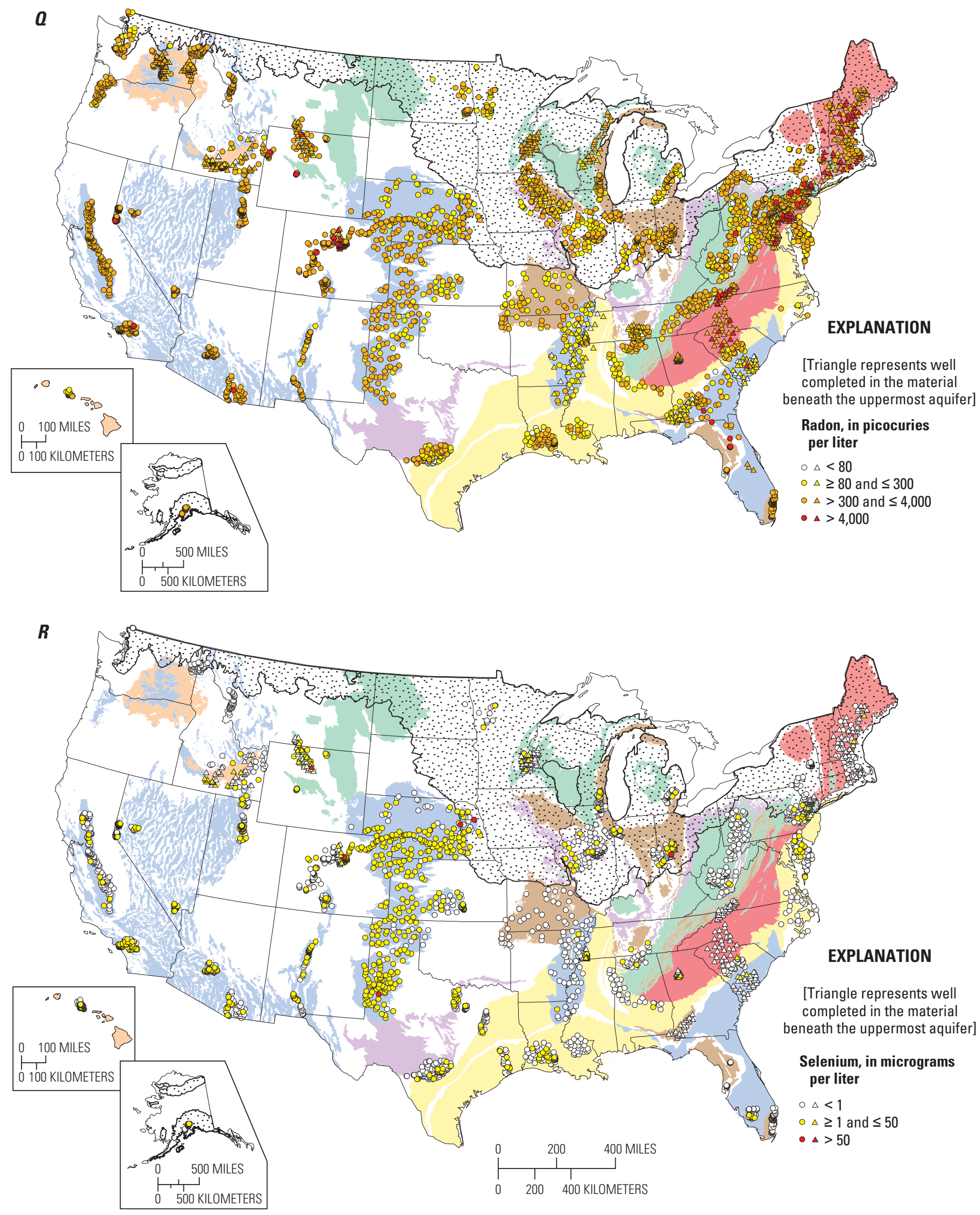

Figure 4. Geographic distribution of trace-element concentrations in groundwater collected from wells as part of the National WaterQuality Assessment Program, 1992-2003: $(A)$ aluminum, $(B)$ antimony, $(C)$ arsenic, $(D)$ barium, $(E)$ beryllium, $(F)$ boron, $(G)$ cadmium, $(H)$ chromium, (I) cobalt, (J) copper, $(K)$ iron, $(L)$ lead, $(M)$ lithium, $(N)$ manganese, $(O)$ molybdenum, $(P)$ nickel, $(Q)$ radon, $(R)$ selenium, $(S)$ silver, $(T)$ strontium, $(U)$ thallium, $(V)$ uranium, $(W)$ vanadium, and $(X)$ zinc.-Continued 

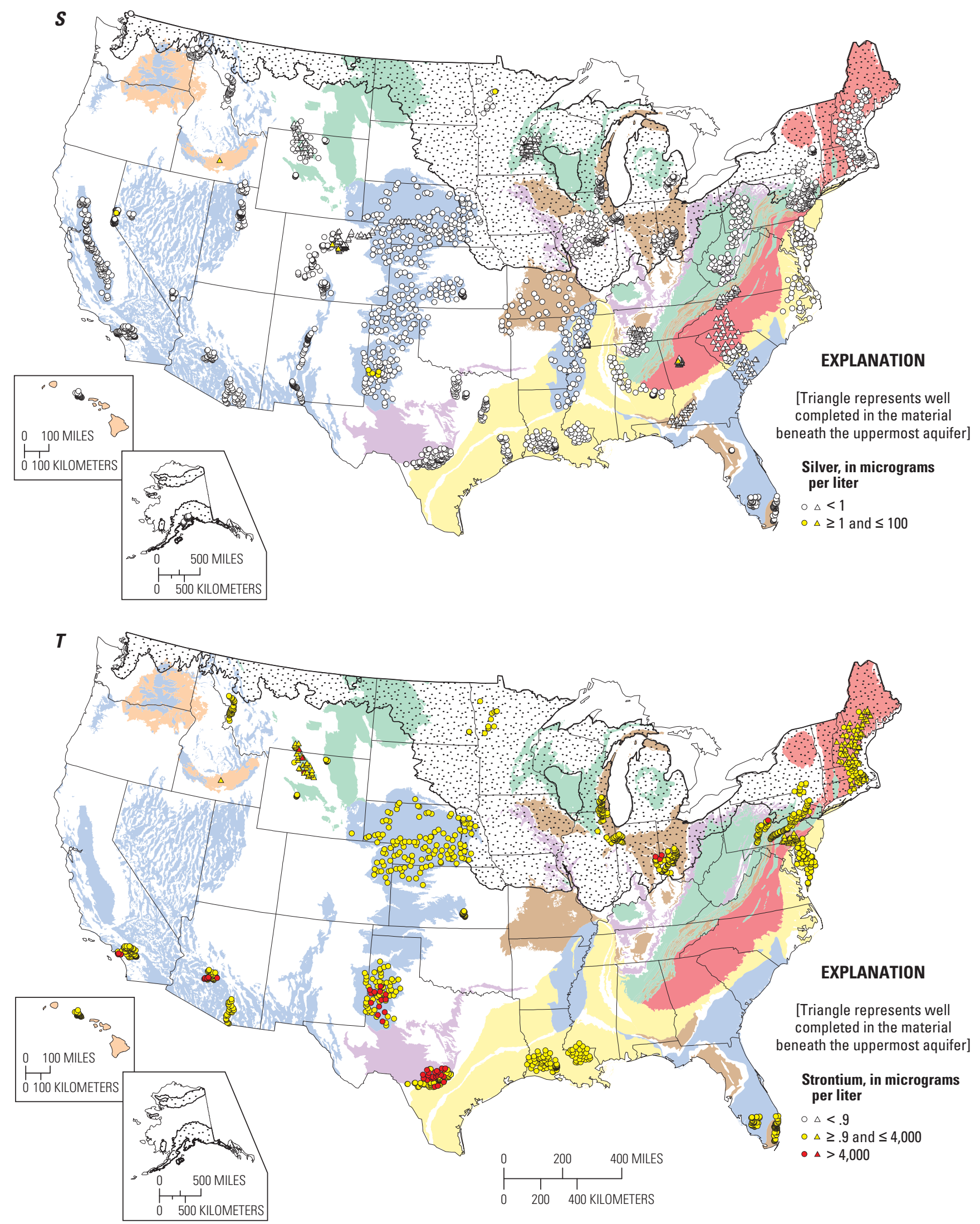

Figure 4. Geographic distribution of trace-element concentrations in groundwater collected from wells as part of the National WaterQuality Assessment Program, 1992-2003: $(A)$ aluminum, $(B)$ antimony, $(C)$ arsenic, $(D)$ barium, $(E)$ beryllium, $(F)$ boron, $(G)$ cadmium, $(H)$ chromium, (I) cobalt, $(J)$ copper, $(K)$ iron, $(L)$ lead, $(M)$ lithium, $(N)$ manganese, $(O)$ molybdenum, $(P)$ nickel, $(Q)$ radon, $(R)$ selenium, $(S)$ silver, $(T)$ strontium, $(U)$ thallium, $(V)$ uranium, $(W)$ vanadium, and $(X)$ zinc.-Continued 

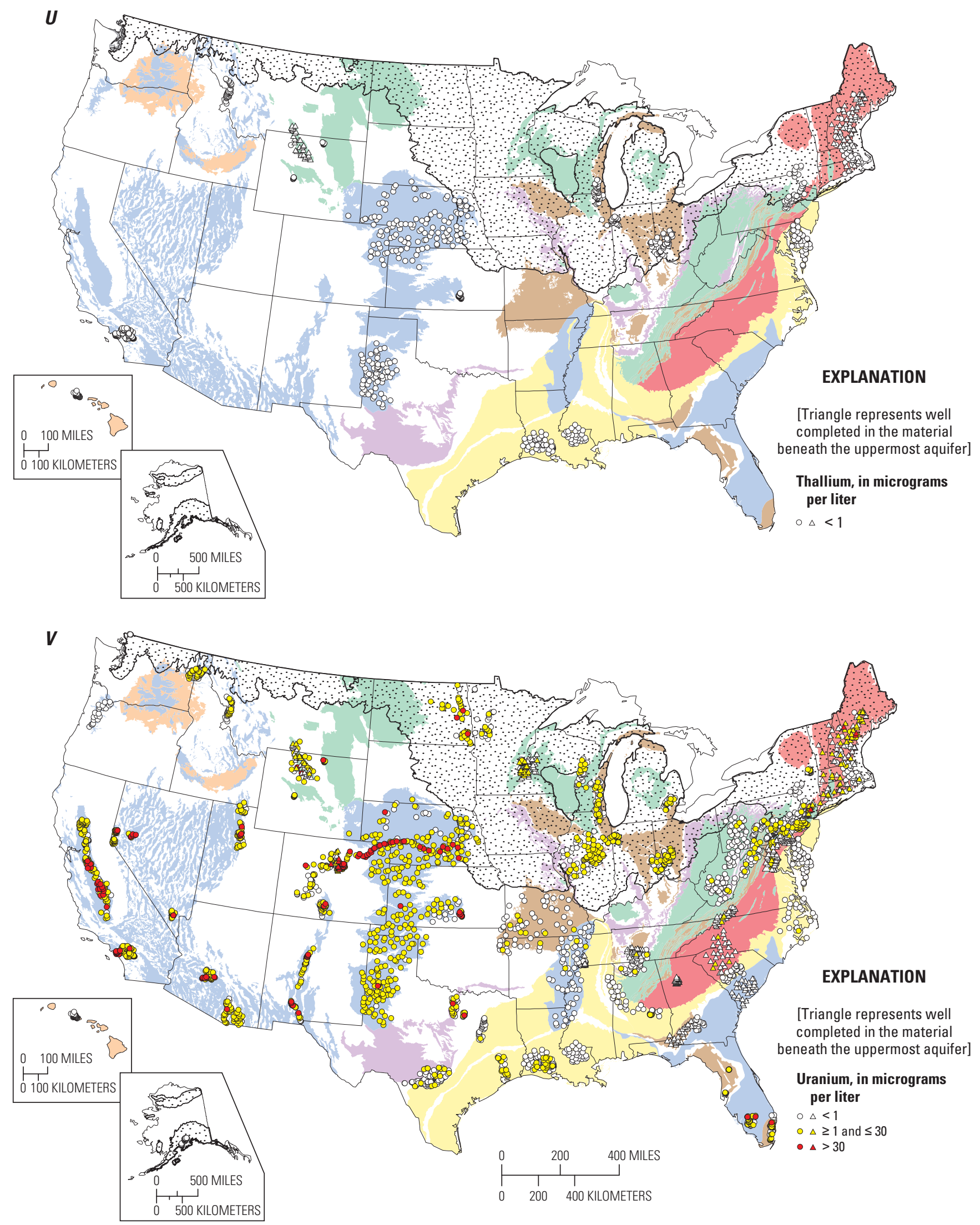

Figure 4. Geographic distribution of trace-element concentrations in groundwater collected from wells as part of the National WaterQuality Assessment Program, 1992-2003: $(A)$ aluminum, $(B)$ antimony, $(C)$ arsenic, $(D)$ barium, $(E)$ beryllium, $(F)$ boron, $(G)$ cadmium, $(H)$ chromium, (I) cobalt, $(J)$ copper, $(K)$ iron, $(L)$ lead, $(M)$ lithium, $(N)$ manganese, $(O)$ molybdenum, $(P)$ nickel, $(Q)$ radon, $(R)$ selenium, $(S)$ silver, $(T)$ strontium, $(U)$ thallium, $(V)$ uranium, $(W)$ vanadium, and $(X)$ zinc.-Continued 

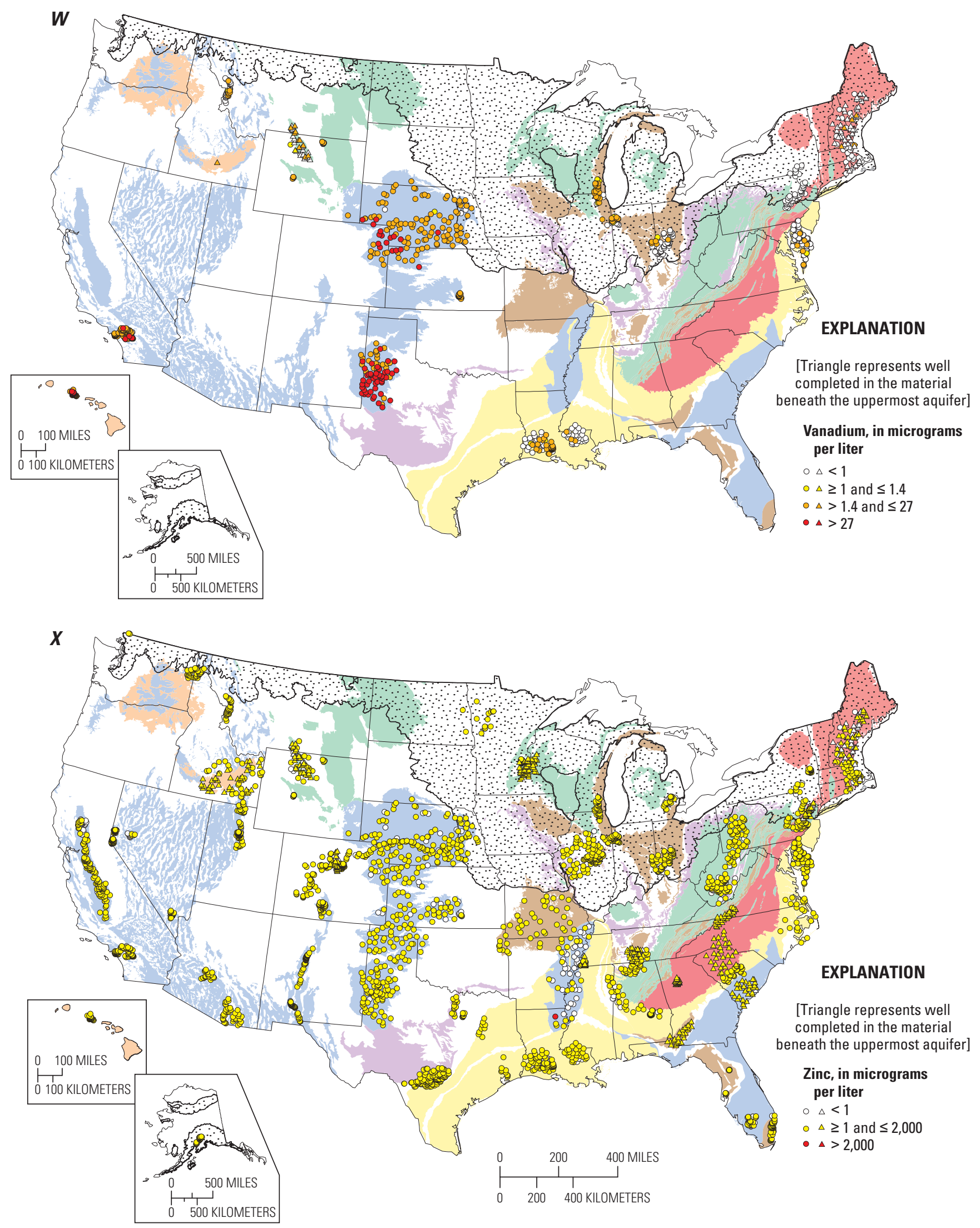

Figure 4. Geographic distribution of trace-element concentrations in groundwater collected from wells as part of the National WaterQuality Assessment Program, 1992-2003: $(A)$ aluminum, $(B)$ antimony, $(C)$ arsenic, $(D)$ barium, $(E)$ beryllium, $(F)$ boron, $(G)$ cadmium, $(H)$ chromium, (I) cobalt, (J) copper, (K) iron, (L) lead, (M) lithium, (N) manganese, $(O)$ molybdenum, $(P)$ nickel, $(Q)$ radon, $(R)$ selenium, $(S)$ silver, $(T)$ strontium, $(U)$ thallium, $(V)$ uranium, $(W)$ vanadium, and $(X)$ zinc.-Continued 


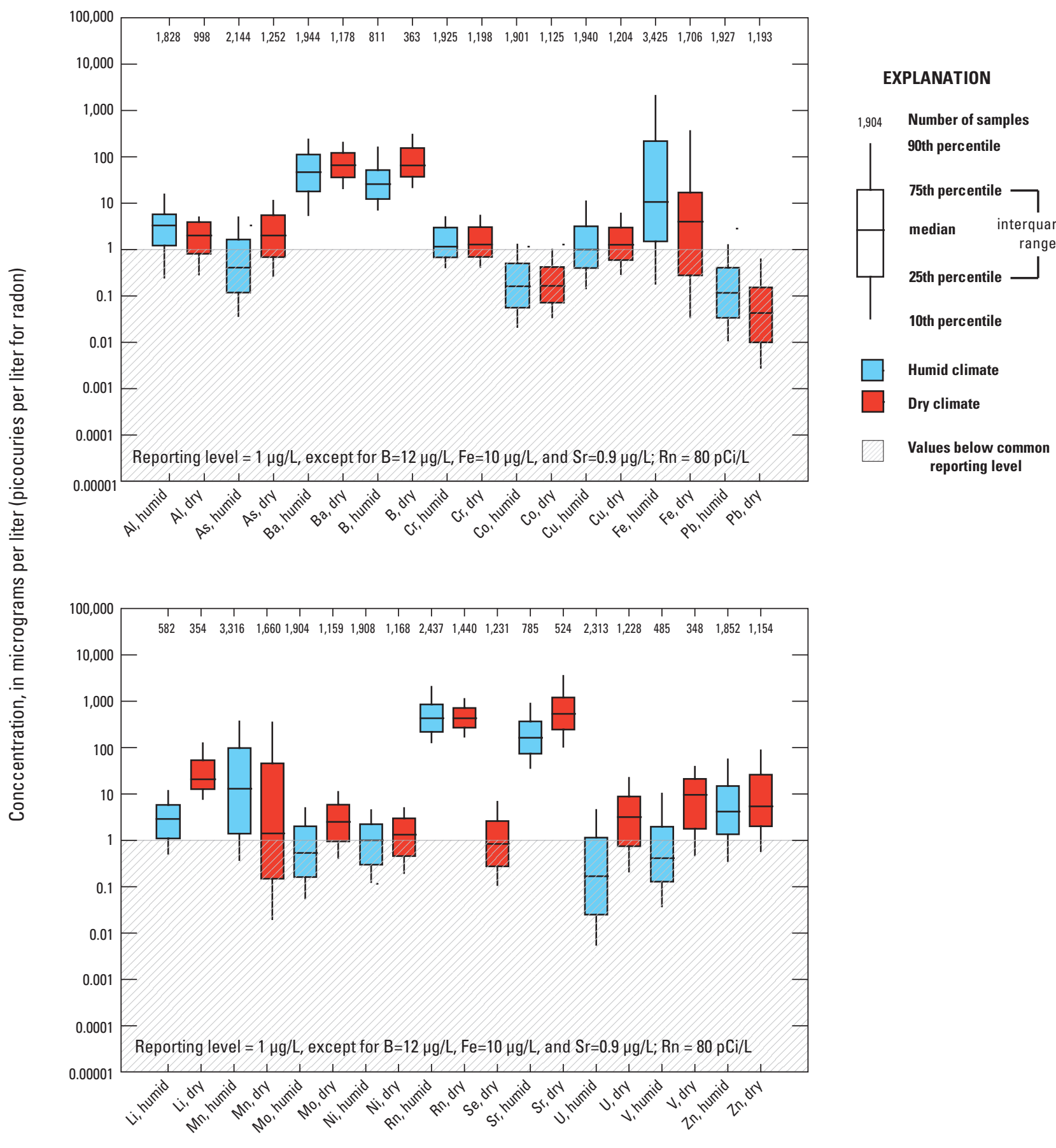

Trace element and climate

Figure 5. Trace-element concentrations in groundwater across the United States by climate region. [Concentrations below the common reporting level $(1 \mu \mathrm{g} / \mathrm{L}$, unless otherwise noted) were estimated by using regression-on-order statistics (see text for explanation). Elements with more than 80 percent of censored data (table 5) are not shown. $\mu \mathrm{g} / \mathrm{L}$, micrograms per liter; pCi/L, picocuries per liter (for radon)] 


\section{Trace-Element Occurrence and Concentrations in Wells in Agricultural and Urban Areas}

Contaminants that are introduced at the land surface can affect water quality in underlying aquifers. Some trace elements have anthropogenic sources that are a direct result of land use. An example of this is the use of B in fertilizer in agricultural settings. Land use may not have a direct effect but can result in changes in groundwater $\mathrm{pH}$, TDS, or redox conditions, which in turn can affect the solubility of naturally occurring trace elements. These changes can either enhance or inhibit the solubility of trace elements in groundwater. For example, Se can be concentrated by evaporation or by irrigation return flow (Seiler and others, 2003). Moreover, studies in agricultural areas in the northeastern United States show that organic As added to poultry feed is converted to inorganic As and loaded to the soil zone, where it may be soluble under favorable redox conditions (Rutherford and others, 2003; Stolz and others, 2007). Arsenic also has historically been used as a pesticide for orchard and row crops (D'Angelo and others, 1996; Hinkle and Polette, 1999; Loiselle and others, 2001). Many studies acknowledge that anthropogenic sources of As in groundwater cannot be ruled out, but most suggest that groundwater As sources are predominantly natural (Hinkle and Polette, 1999; Welch and others, 2000; Ayotte and others, 2003; Peters and Blum, 2003; Welch and Stollenwerk, 2003; Robinson and Ayotte, 2006; Robinson and Ayotte, 2007). Geochemical conditions near waste sites, such as landfills, however, may be altered sufficiently to allow Fe and Mn hydroxide dissolution, resulting in the mobilization of otherwise sequestered soil As and other metals (Stollenwerk and Colman, 2004; deLemos and others, 2006).

The concentrations of trace elements were compared between wells representing primarily agricultural and urban land uses (table 8). In this comparison, water samples from wells in agricultural settings have greater concentrations of some trace elements, such as As, Mo, and U, than samples from wells in urban settings, regardless of climate. Concentrations of $\mathrm{DO}$ and $\mathrm{pH}$ values also were greater in water samples from agricultural wells than in samples from urban wells. Significantly greater concentrations of B, Cr, Se, $\mathrm{Ag}, \mathrm{Sr}$, and $\mathrm{V}$ also were found in samples from agricultural wells in dry regions. Concentrations of $\mathrm{Pb}$ were greater in water samples from wells in agricultural settings than in samples from urban wells in humid regions, but the converse was true for dry regions.

Water sampled from urban wells in both climate regions generally had greater concentrations of $\mathrm{Fe}, \mathrm{Li}$, and $\mathrm{Mn}$ than water from agricultural wells, possibly because urban-well water also had lower $\mathrm{pH}$ and DO (table 8). Collectively, the urban-well samples were more anoxic than agricultural-well samples, and this result may partly explain why the urban-well samples had fewer HHB or guideline exceedences of oxyanion-forming elements, and why trace elements that are more mobile under anoxic conditions, such as Fe and Mn, were generally prevalent.

\section{Comparisons of Trace-Element Concentrations in Groundwater to Human-Health Benchmarks}

HHBs were defined for many trace elements to ensure that high-quality safe drinking water is provided to people using publicly supplied water. The results in this section are not intended to be interpreted as estimates of potential exposure, but rather as a simple comparison to identify geographic areas where concentrations of trace elements in groundwater were found by the NAWQA Program to be greater than established or proposed HHBs. Not all water samples collected for this study were from drinking-water wells; about 40 percent were monitoring wells. The trace elements with $\mathrm{HHBs}$ are $\mathrm{Sb}$, As, Ba, Be, B, Cd, Cr, Cu, Pb, Mn, Mo, Ni, Se, Ag, Sr, Tl, U, and $\mathrm{Zn}$; however, it is important to note that, for this summary, not all trace elements were analyzed in samples from all of the selected wells. Comparison of these data to HHBs is intended, in part, to provide a context for analysis of specific trace elements in specific areas of the United States.

For the analysis presented here, wells were selected irrespective of well type or land use (4,527 wells). In 19 percent of samples collected from those wells, at least one trace element exceeded an HHB (table 9). Wells with HHB exceedences were widespread across the United States; they occurred in all aquifer groups and in both humid and dry regions.

For trace elements, wells in urban settings had greater rates of HHB exceedences than agricultural wells or drinkingwater wells in varied land-use settings (table 9). In addition, monitoring wells tended to have greater HHB-exceedence rates than drinking-water wells. For some contaminants in groundwater, such as nitrate and volatile organic compounds (VOCs), differences in land use (as an indicator of contaminant source) can have a profound effect on rates of HHB exceedences. For trace elements, however, the differences may be more related to redox, $\mathrm{pH}$, and other conditions than to source indicators, although anthropogenic activities can change redox conditions and thereby can change concentrations of naturally occurring trace elements in groundwater. In general, the wells in the urban and agricultural categories (dominantly monitoring wells) are shallow water-table wells, where the $\mathrm{pH}$ in groundwater is commonly low and DO high. Water in a greater percentage of wells in major aquifers (dominantly drinking-water wells) was found to have a higher $\mathrm{pH}$ and lower DO than water sampled from the shallow wells. These differences may influence trace-element HHB exceedences, depending on the element.

An important finding from this analysis was that traceelement contamination in groundwater far outpaces contamination in most other commonly assessed groups, such as VOCs, pesticides, and nutrients. In drinking-water wells, one or more trace elements exceeded HHBs in untreated water from 13 percent of public-supply wells and 13 percent of domestic-supply wells (table 9); for pesticides, these rates were 2.2 and 0.76 percent, respectively (Gilliom and others, 2006). Similarly, about 2 percent of public-supply wells and 


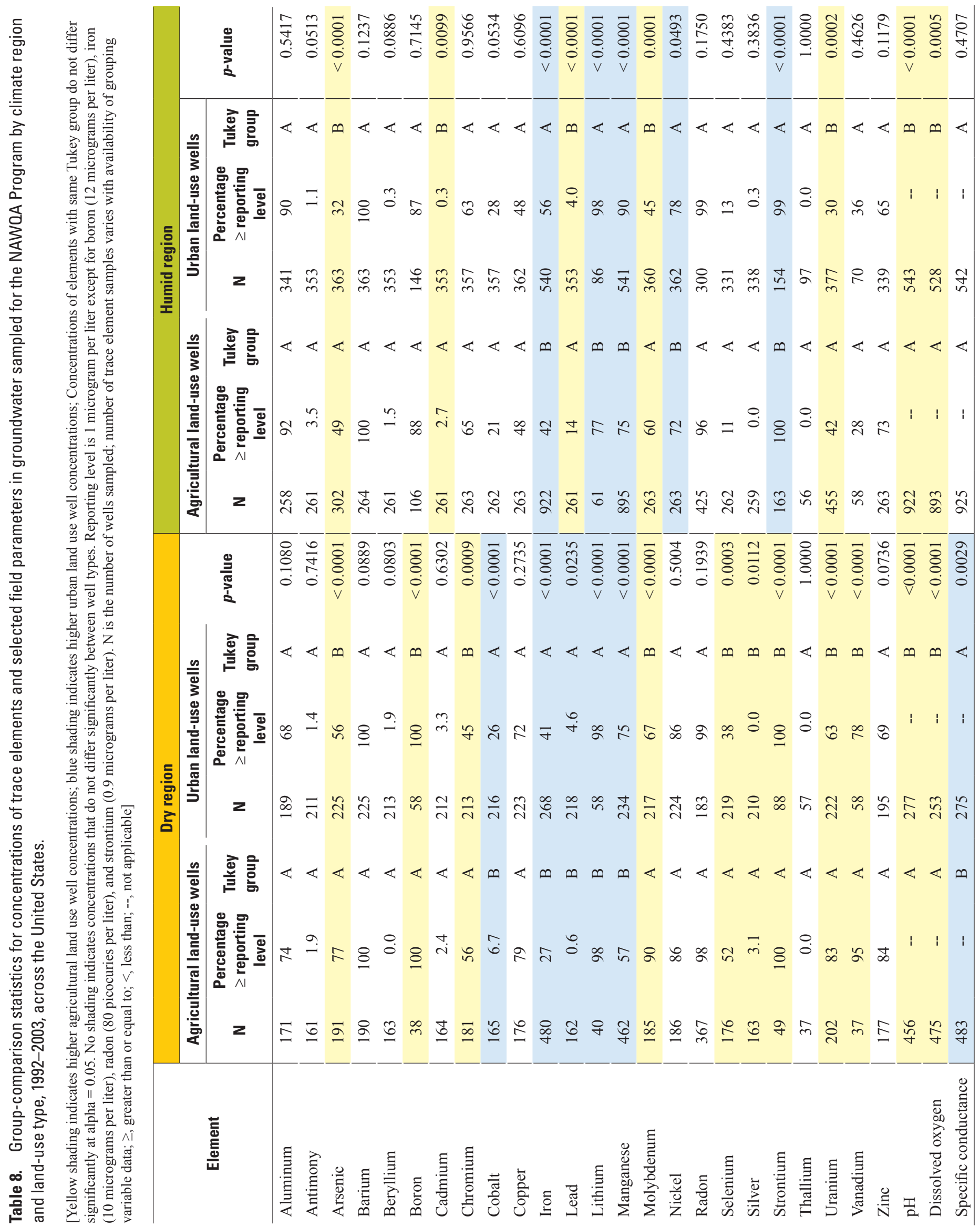


Table 9. Percentage of samples collected across the United States for the NAWQA Program from which one or more trace elements exceeded human-health benchmarks by primary water use and study type, 1992-2003.

[TE, trace elements; VOCs, volatile organic compounds; --, not applicable]

\begin{tabular}{|c|c|c|c|c|c|c|c|c|}
\hline \multirow[b]{2}{*}{ Study type } & \multicolumn{2}{|c|}{ Public-supply wells } & \multicolumn{2}{|c|}{ Domestic-supply wells } & \multicolumn{2}{|c|}{ Monitoring wells } & \multicolumn{2}{|c|}{ All wells } \\
\hline & $\begin{array}{l}\text { Number } \\
\text { sampled }\end{array}$ & $\begin{array}{l}\text { Percentage } \\
\text { of samples } \\
\text { exceeding } \\
\text { benchmark }\end{array}$ & $\begin{array}{l}\text { Number } \\
\text { sampled }\end{array}$ & $\begin{array}{l}\text { Percentage } \\
\text { of samples } \\
\text { exceeding } \\
\text { benchmark }\end{array}$ & $\begin{array}{l}\text { Number } \\
\text { sampled }\end{array}$ & $\begin{array}{l}\text { Percentage } \\
\text { of samples } \\
\text { exceeding } \\
\text { benchmark }\end{array}$ & $\begin{array}{l}\text { Number } \\
\text { sampled }\end{array}$ & $\begin{array}{r}\text { Percentage } \\
\text { of samples } \\
\text { exceeding } \\
\text { benchmark }\end{array}$ \\
\hline \multicolumn{9}{|c|}{ Trace-element studies } \\
\hline Agricultural land use & 0 & -- & 402 & 9.5 & 904 & 26 & 1,306 & 21 \\
\hline Urban land use & 9 & 33 & 17 & 29 & 740 & 28 & 766 & 28 \\
\hline Major aquifer study & 372 & 12 & 1,895 & 13 & 188 & 26 & 2,455 & 14 \\
\hline All TE studies & 381 & 13 & 2,314 & 13 & 1,832 & 27 & 4,527 & 19 \\
\hline \multicolumn{9}{|c|}{ Other contaminant groups } \\
\hline All VOCs studies ${ }^{1}$ & 340 & 2.1 & 1,606 & 1.1 & 1,060 & 1.5 & 3,006 & 1.4 \\
\hline All pesticides studies ${ }^{2}$ & 364 & 2.2 & 2,356 & 0.76 & 2,293 & 2.5 & 5,013 & 1.7 \\
\hline All nitrate studies ${ }^{3}$ & 384 & 3.0 & 2,388 & 7.0 & 1,902 & 12 & 4,674 & 8.7 \\
\hline
\end{tabular}

'Zogorski and others, 2006.

${ }^{2}$ Gilliom and others, 2006.

${ }^{3}$ Dubrovsky and others, 2010.

1 percent of domestic-supply wells had one or more VOCs greater than HBSLs (Zogorski and others, 2006). Nitrate exceeded its MCL in 3 percent of public-supply-well samples and 7 percent of domestic-supply-well samples (Dubrovsky and others, 2010), yet still did not approach the exceedence rate for trace elements.

HHB exceedences varied by element. Overall, 17 of 19 trace elements with defined HHBs had some exceedences (table 4). Seven of the 19 exceeded benchmarks in at least 1 percent of water samples (table 4). Mn occurred most often at concentrations greater than its HHB (12 percent), followed by As (7.0 percent), Sr (4.3 percent), U (4.0 percent), B (1.9 percent) and Mo (1.5 percent). $\mathrm{Rn}$ is a special case because it has a proposed two-tier benchmark that accommodates state-specific programs related to the mitigation of $\mathrm{Rn}$ in air. In the case of Rn, 65 percent of samples had concentrations greater than the USEPA-proposed MCL of $300 \mathrm{pCi} / \mathrm{L}$, and 2.7 percent had concentrations greater than the USEPA-proposed AMCL of 4,000 pCi/L (table 4). For all other elements with defined HHBs, concentrations greater than those benchmarks occurred in fewer than 1 percent of samples. Similar rates of exceedence of HHBs for trace elements were found in a study that used only domestic wells sampled by the NAWQA Program (DeSimone, 2009). Radionuclides, As, $\mathrm{Mn}, \mathrm{Sr}$, and B were the contaminants exceeding HHBs most frequently in a national study of source-water samples from public wells (Toccalino and others, 2010).

Because trace elements tend to occur at different concentrations in dry and humid climates, the rates of HHB exceedence also vary by climate. For example, in dry regions, concentrations of As exceeded the MCL of $10 \mu \mathrm{g} / \mathrm{L}$ in 11 percent of samples compared to fewer than 5 percent in humid regions (table 5). Sr concentrations were greater than the HBSL of 4,000 $\mu \mathrm{g} / \mathrm{L}$ in about 9 percent of dry-region samples compared to 1 percent in humid regions. $U$ exceeded the $30 \mu \mathrm{g} / \mathrm{L}$ MCL in 7.5 percent of dry-region samples and in only 2.1 percent of humid-region samples (table 5 ). Se concentrations in groundwater were not commonly greater than the USEPA MCL of $50 \mu \mathrm{g} / \mathrm{L}$ but were greater than the MCL about 8 times more frequently in the dry-region samples than in the humid-region samples $(0.4$ and 0.05 percent, respectively). As discussed previously, these differences may reflect the generally high mobility of some of these elements (As, Se, U) in high-pH, high-TDS groundwater.

\section{Trace-Element Occurrence and Concentrations in Groundwater by Major Aquifer Group}

Groundwater trace-element occurrences in relation to aquifer geology are described for eight major groups of aquifers in the United States. Most wells in aquifers sampled 
in this study were in humid regions, although the basaltic- and other volcanic-rock (BAV) aquifers were in predominantly dry regions. Only aquifers in unconsolidated sand and gravel (USG) and in sandstone and carbonate rock (SCR) had fewer than 85 percent of wells in one climate region. For samples from the SCR group, 79 of the 222 (36 percent) were in humid regions. Groundwater samples in the USG aquifer group (the largest group of samples in this study) were more evenly split between dry and humid regions, with 723 of the 1,801 wells (40 percent) in humid regions.

Dominant water types, based on major-ion chemistry, were determined to provide a description of each major aquifer group (fig. 6). Because some ions are geochemically active or redox sensitive, water type is useful in analyzing the occurrence of some trace elements. Trace-element and Rn concentrations in groundwater were compared to current and proposed HHBs. In many cases, median concentrations of a trace element in the aquifer groups were less than the corresponding HHBs, so higher percentiles, such as the 75th or 95th percentiles, were compared. In selected cases, sources and processes controlling trace-element concentrations and, if applicable, unusually high or low concentrations were examined.

Summary statistics (percentiles) of the concentrations of trace elements and Rn and the percentages of samples in which concentrations exceeded current and proposed HHBs and nonhealth guidelines for each major aquifer group are shown in appendix 3 . The median concentrations for all trace elements in all of the major aquifer groups were less than established HHBs and nonhealth guidelines (table 10). Radon concentrations, however, were greater than the USEPA-proposed MCL of $300 \mathrm{pCi} / \mathrm{L}$ in more than 50 percent of wells in five of the eight aquifer groups (table 10).

Groundwater concentrations of 12 different elements were above current or proposed HHBs (or nonhealth guidelines) in at least 1 percent of samples in at least one aquifer group (table 10, blue shading). Fe, Mn, and Rn exceeded HHBs (or nonhealth guidelines) in some water samples in all aquifer groups. The USG, GLA, and SAN aquifer groups had at least eight elements that exceeded current or proposed HHBs or nonhealth guidelines in at least 1 percent of water samples, and $\mathrm{Al}, \mathrm{As}, \mathrm{Fe}, \mathrm{Mn}, \mathrm{Rn}$, and $\mathrm{Sr}$ concentrations exceeded HHBs or nonhealth guidelines in all three aquifer groups. The SCS, SCR, CAR, and BAV groups had five or fewer elements that exceeded current or proposed HHBs or nonhealth guidelines in at least 1 percent of water samples (combinations of $\mathrm{As}, \mathrm{Fe}, \mathrm{Pb}, \mathrm{Mn}, \mathrm{Rn}$, or $\mathrm{Sr}$ ). The $\mathrm{CRL}$ aquifer group was similar but also included HHB or nonhealth-guideline exceedences of $\mathrm{U}$ and $\mathrm{Al}$. Sr exceeded HHBs or nonhealth guidelines in at least 1 percent of the water samples from the USG, GLA, SAN, and SCR aquifer groups, but in the SCR, more than 26 percent exceeded the HHBs or nonhealth guidelines. Mo exceeded HHBs or nonhealth guidelines in more than 1 percent of the samples in the USG and GLA aquifer groups (table 10).

\section{Unconsolidated Sand and Gravel Aquifers (USG)}

Groundwater samples from the USG aquifer group were predominantly of the calcium-magnesium-bicarbonate (Ca-Mg-bicarbonate or mixed bicarbonate) type (fig. 6A) with a median $\mathrm{pH}$ of 7.3 (fig. 7). These samples had the largest variability in water type, however, with many samples in the sodium-chloride $(\mathrm{Na}-\mathrm{Cl})$ and $\mathrm{Ca}-\mathrm{Mg}$-sulfate fields; this variability may be related to differences in the lithologic compositions of the original source materials from which the sand and gravel was derived, as well as climate differences between the sampling locations.

Generally, trace-element concentrations in groundwater samples from USG wells are among the highest of any of the aquifer groups described in this report. Concentrations of As, B, Li, Mo, Se, U, and V (and HHB exceedences) were generally greater in the USG than in any other aquifer groups (table 10).

About 9 percent of water samples in the USG have $\mathrm{U}$ concentrations above the USEPA drinking water MCL (table 10). This is the greatest rate among all of the aquifer groups for $\mathrm{U}$ and accounts for about 95 percent of all $\mathrm{U}$ HHB exceedences. Sr exceeded the HHB of $4,000 \mu \mathrm{g} / \mathrm{L}$ in 5.2 percent of samples (mostly in western aquifers), which accounts for about 45 percent of $\mathrm{Sr}$ benchmark exceedences for all aquifer groups combined.

Concentrations of As and $\mathrm{U}$ in all groundwater samples in the USG aquifer group were most often above the USEPA drinking water MCLs of 10 and $30 \mu \mathrm{g} / \mathrm{L}$, respectively, in the western principal aquifers, such as the Basin and Range basinfill aquifers, California Coastal Basin aquifers, Central Valley aquifer system, Rio Grande aquifer system, and High Plains aquifer (figs. 3, 4C and V). In many cases, several oxyanionand ion-complex-forming trace elements are correlated (rho $>0.5)$ with each other and also with bicarbonate, sulfate, and TDS. Many of these samples had relatively high groundwater $\mathrm{pH}$, which can enhance the solubility of trace elements such as As, B, Mo, Se, and U (Dubrovsky and others, 1991; Fujii and Swain, 1995; Welch and others, 2000; Focazio and others, 2001; Smedley and Kinniburgh, 2002; Welch and Stollenwerk, 2003).

In the generally humid eastern regions, As concentrations were greatest in groundwater samples from the Mississippi River Valley alluvial aquifer and the surficial aquifer system (southern Florida). In the Mississippi River Valley alluvial aquifer, the occurrence of As appears to be associated with the reductive dissolution of $\mathrm{Fe}$ oxide coatings on aquifer materials possibly coupled with the oxidation of lignite and peat (Kresse and Fazio, 2003). Uranium occurs in groundwater in the surficial aquifer system (Florida) and may be related to phosphate deposits containing $\mathrm{U}$ in the limestone-derived sediments of the Tamiami Formation (Meyer, 1989). U in shallow oxic groundwaters may form soluble complexes with bicarbonate and phosphate in the aquifer (Meyer, 1989). 
A. Unconsolidated sand and gravel aquifers (USG)

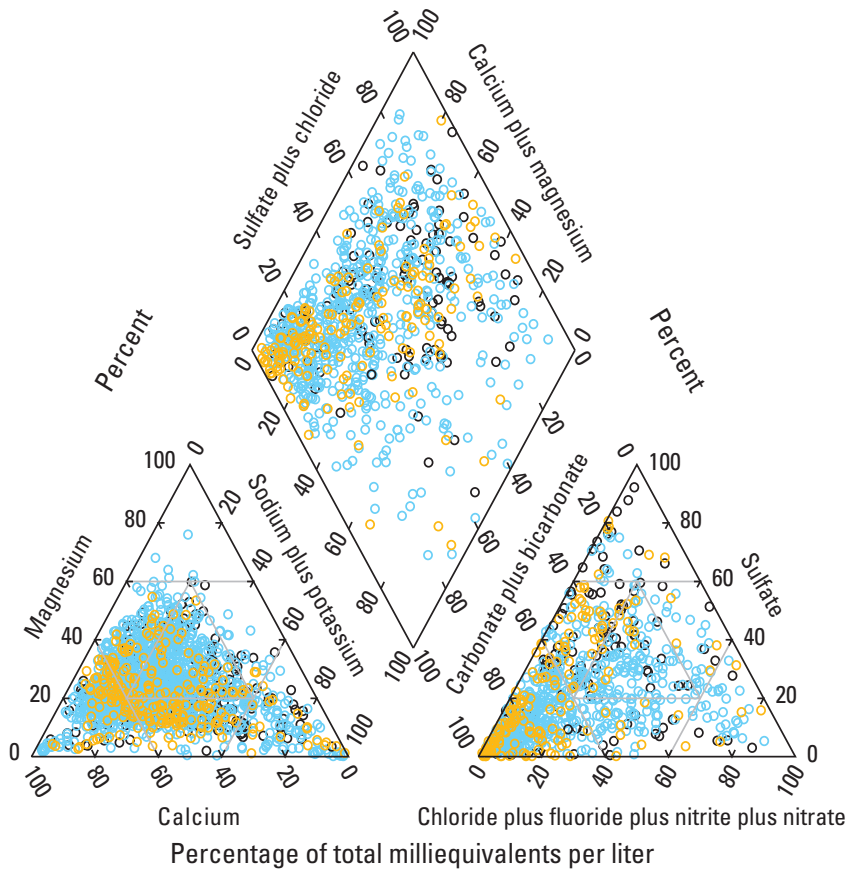

C. Semiconsolidated sand aquifers (SCS)

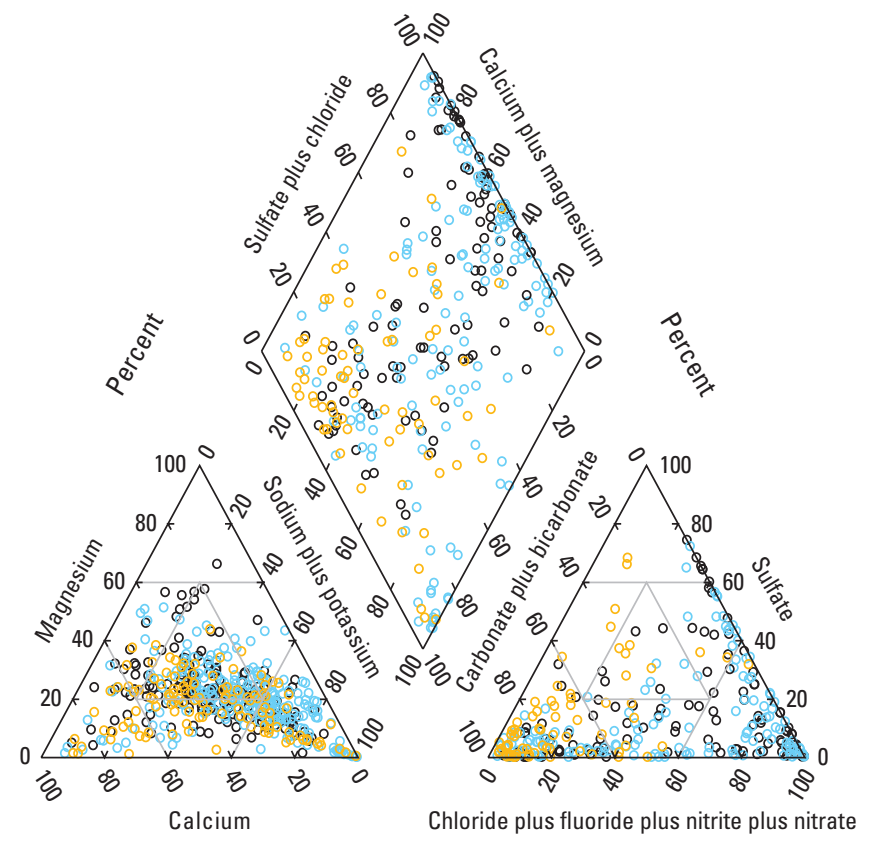

Percentage of total milliequivalents per liter

\section{B. Glacial unconsolidated sand and gravel aquifers (GLA)}

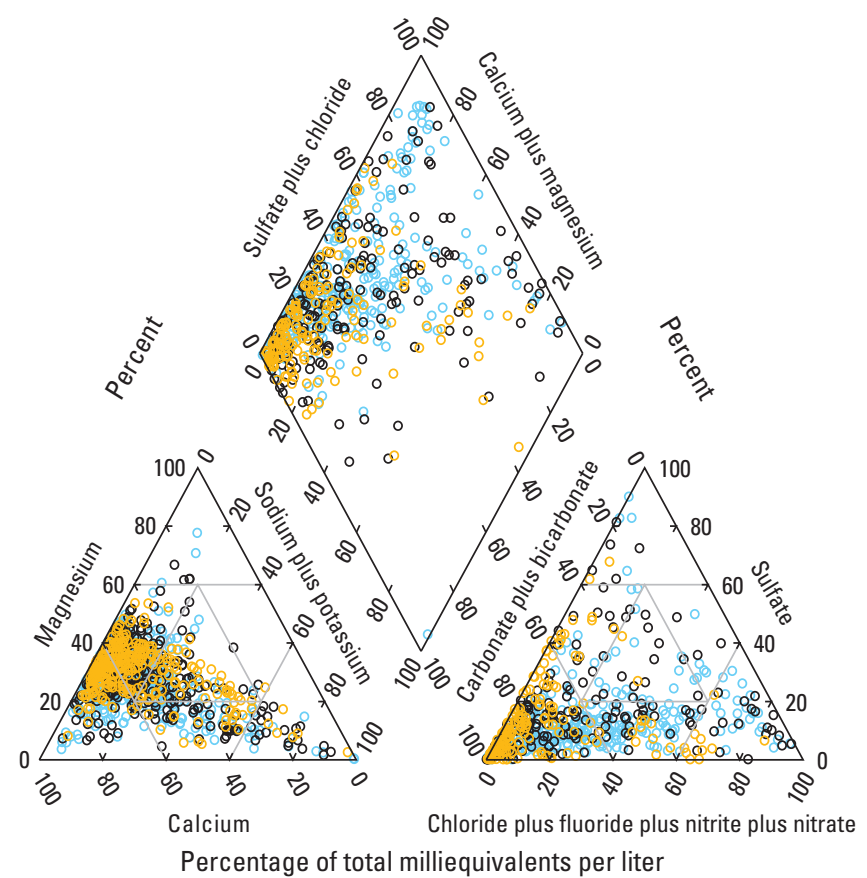

D. Sandstone aquifers (SAN)

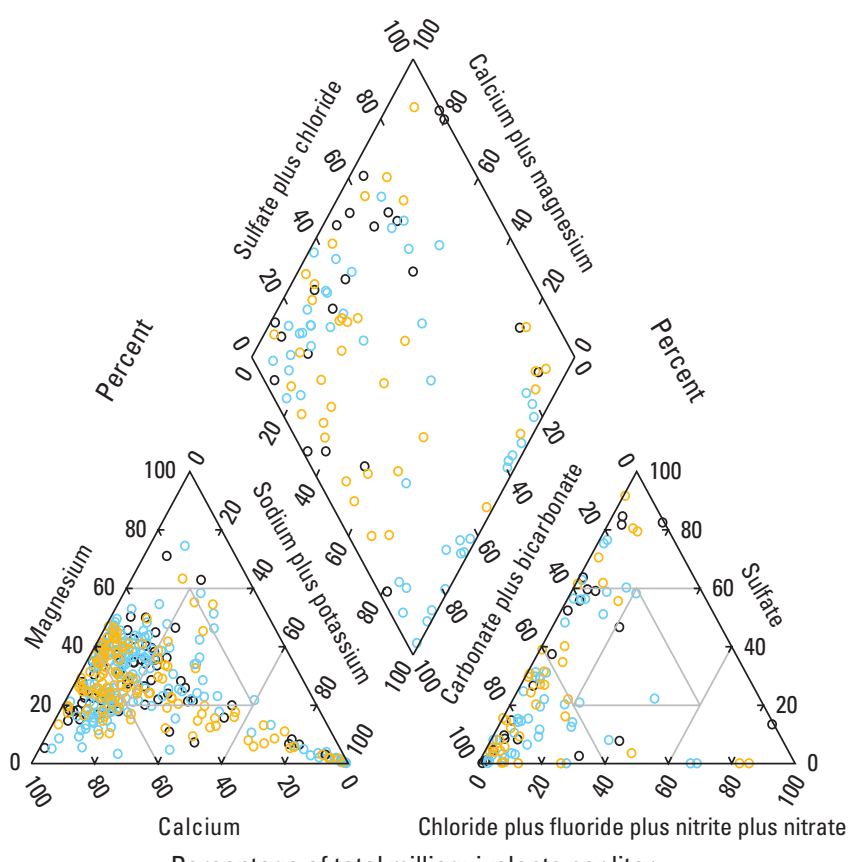

Percentage of total milliequivalents per liter

\section{EXPLANATION}

Figure 6. Major-ion chemistry by redox class for $(A)$ unconsolidated sand and gravel aquifers, $(B)$ glacial unconsolidated sand and gravel aquifers, $(C)$ semiconsolidated sand aquifers, $(D)$ sandstone aquifers, $(E)$ sandstone and carbonate-rock aquifers, $(F)$ carbonaterock aquifers, $(G)$ basaltic- and other volcanic-rock aquifers, and $(H)$ crystalline-rock aquifers. 


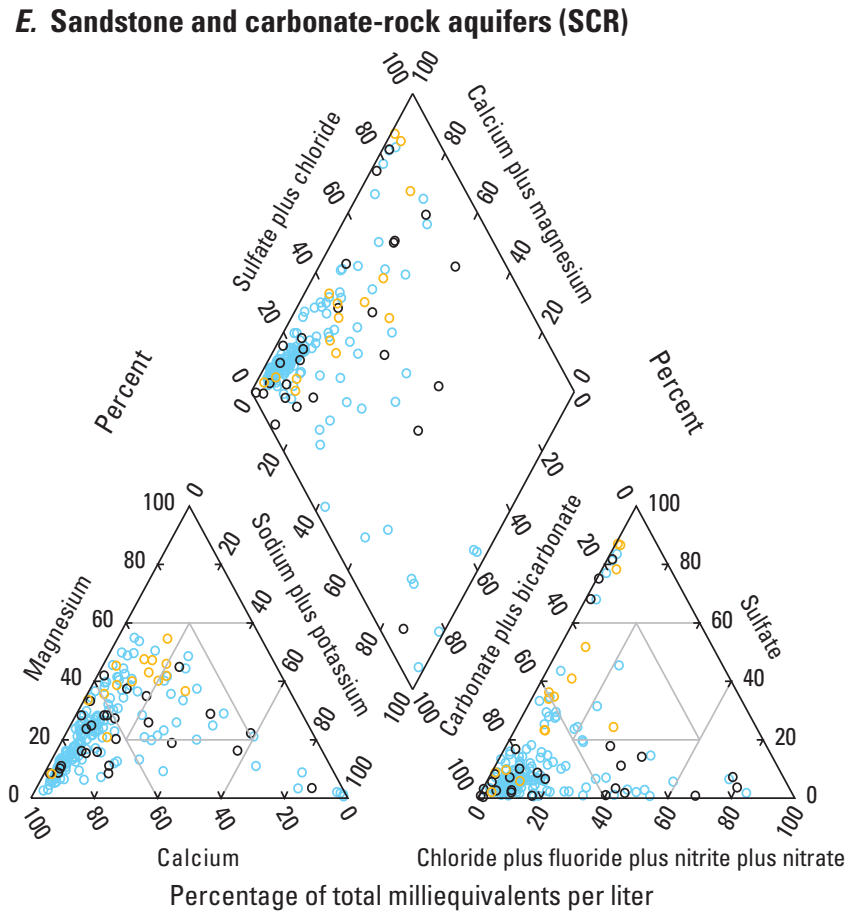

G. Basaltic- and volcanic-rock aquifers (BAV)

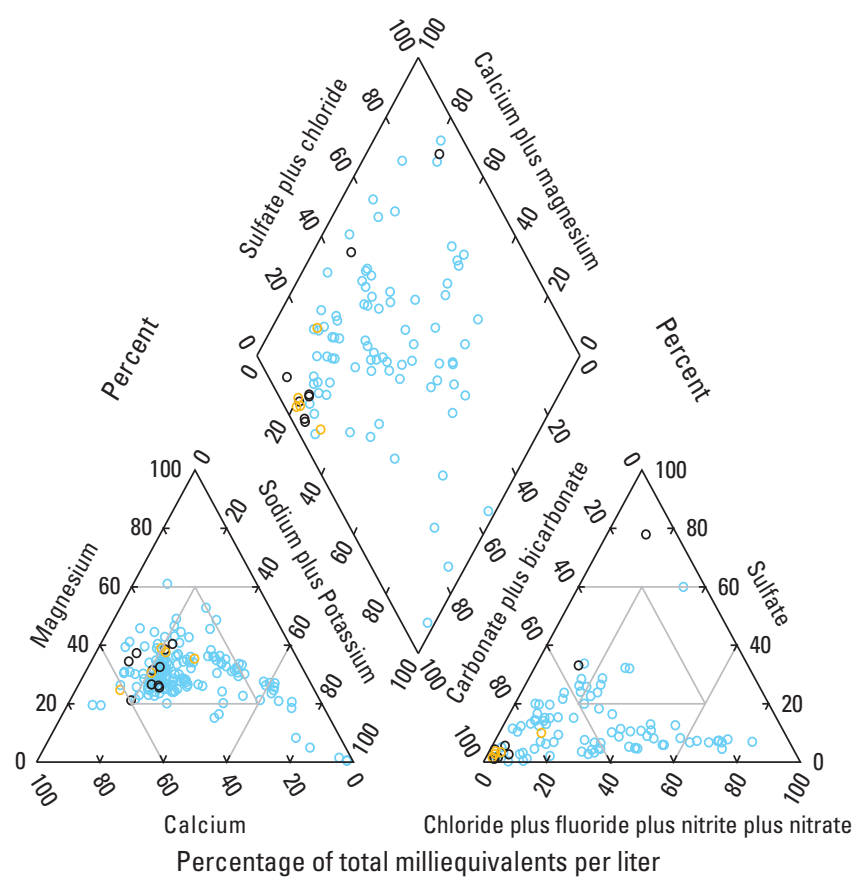

\section{F. Carbonate-rock aquifers (CAR)}

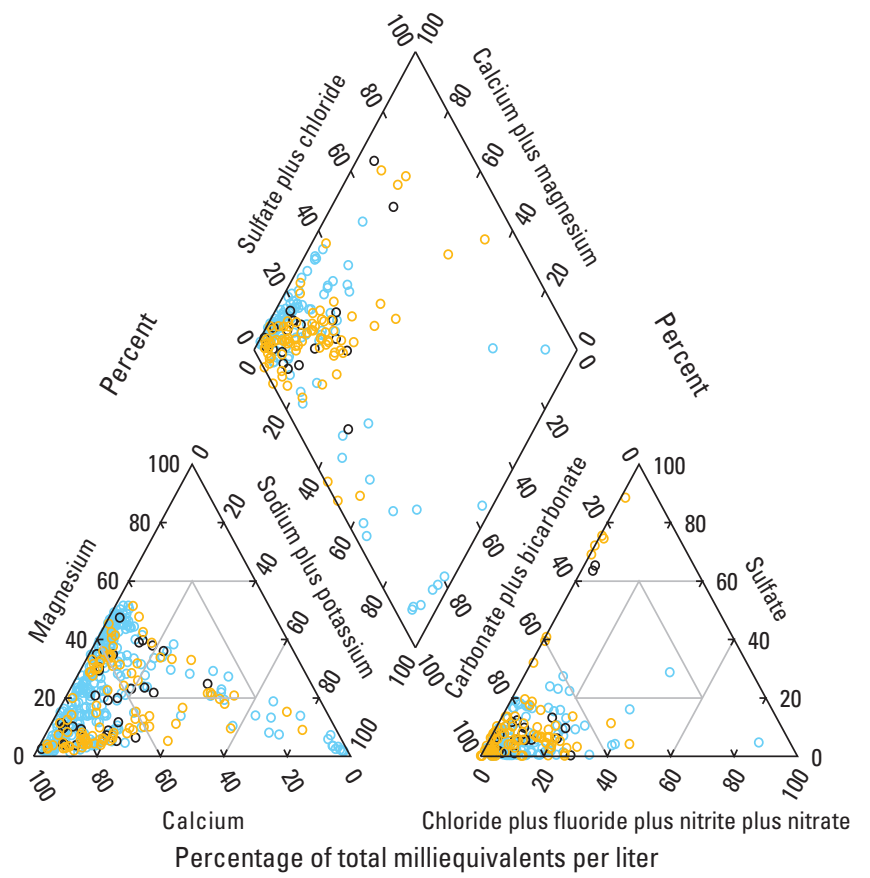

\section{H. Crystalline-rock aquifers (CRL)}

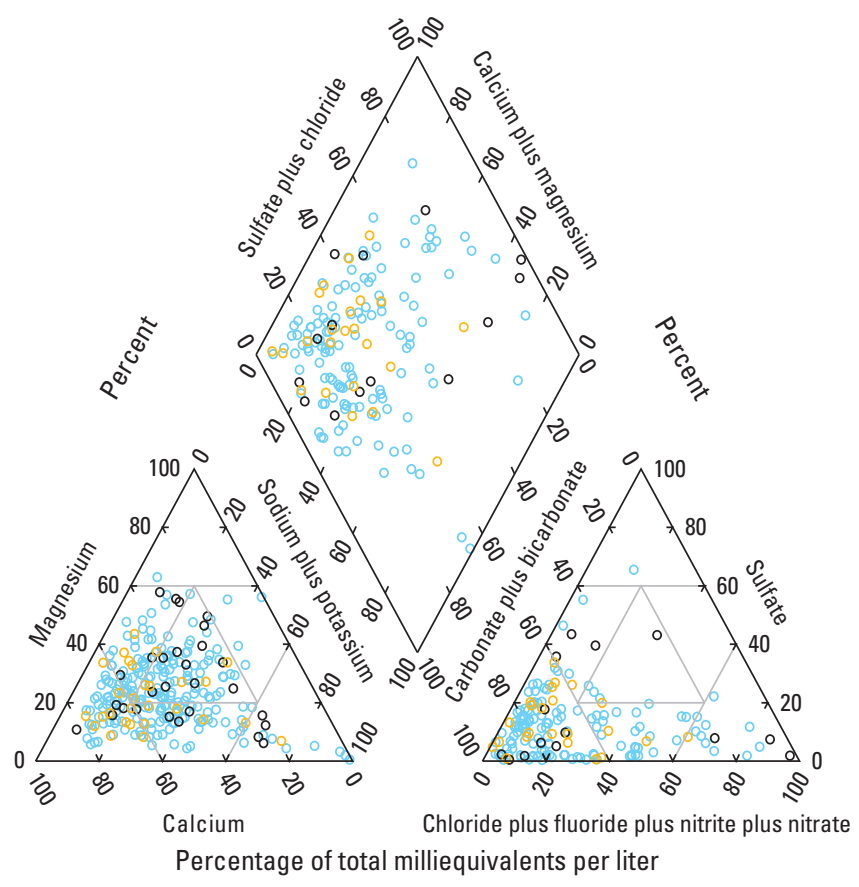

EXPLANATION

Oxic

- Mixed

Anoxic

Figure 6. Major-ion chemistry by redox class for $(A)$ unconsolidated sand and gravel aquifers, $(B)$ glacial unconsolidated sand and gravel aquifers, $(C)$ semiconsolidated sand aquifers, $(D)$ sandstone aquifers, $(E)$ sandstone and carbonate-rock aquifers, $(F)$ carbonaterock aquifers, $(G)$ basaltic- and other volcanic-rock aquifers, and $(H)$ crystalline-rock aquifers.-Continued 


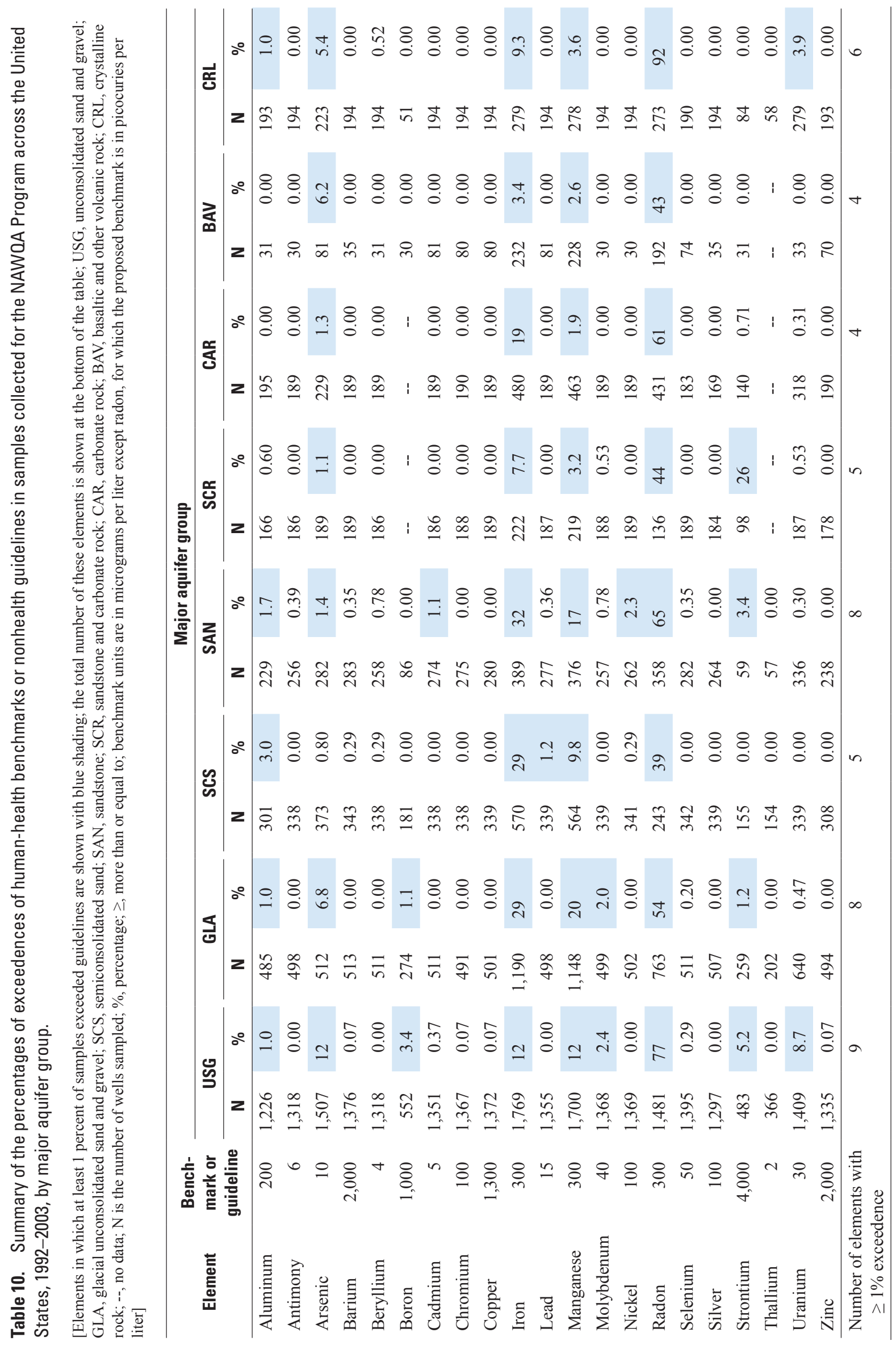




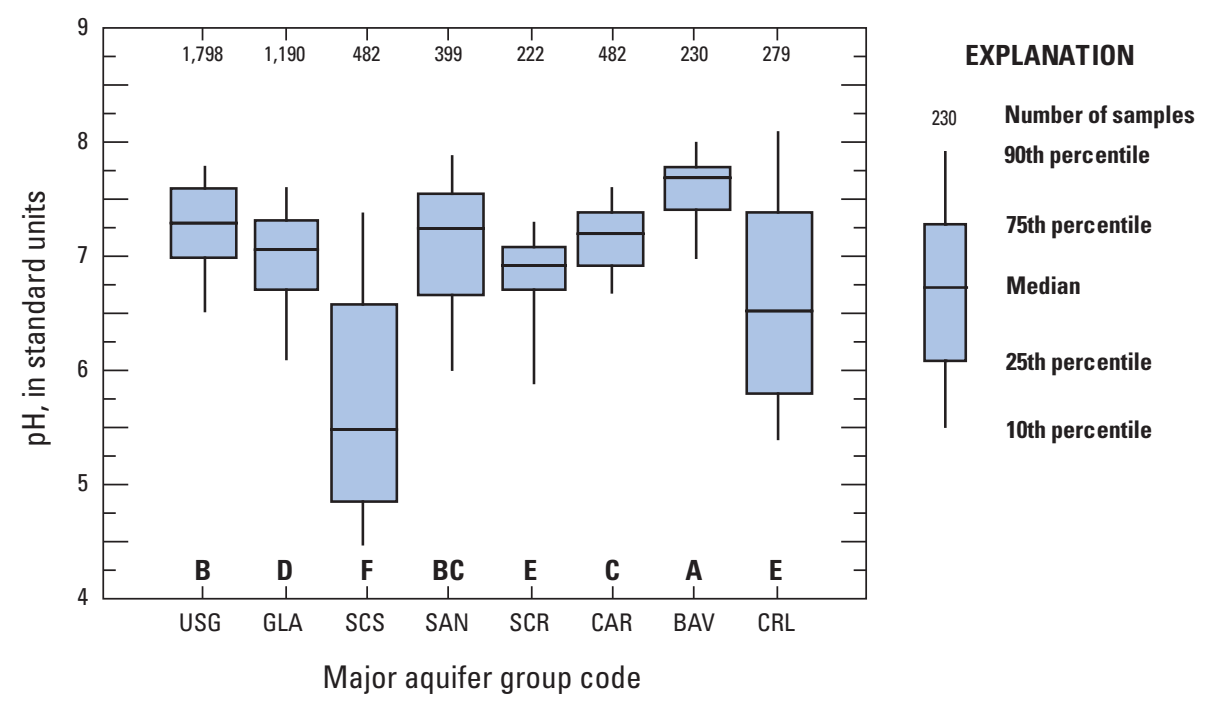

Figure 7. Distributions of $\mathrm{pH}$ by major aquifer group. Letters representing nonparametric Tukey group are shown below boxes. Groups with different letters are significantly different (alpha $=0.05$ ). USG, unconsolidated sand and gravel aquifers; GLA, glacial unconsolidated sand and gravel aquifers; SCS, semiconsolidated sand aquifers; SAN, sandstone aquifers; SCR, sandstone and carbonate-rock aquifers; CAR, carbonate-rock aquifers; BAV, basalticand other volcanic-rock aquifers; and CRL, crystalline-rock aquifers.

\section{Glacial Unconsolidated Sand and Gravel Aquifers (GLA)}

The water type of the GLA groundwater samples was predominantly $\mathrm{Ca}-\mathrm{Mg}$ bicarbonate but with some samples having a $\mathrm{Na}-\mathrm{Cl}$ influence (fig. 6B). The median $\mathrm{pH}$ of samples from this aquifer group was 7.1 (fig. 7). The GLA aquifer group had the greatest percentage of mixed and anoxic samples (and the lowest percent of oxic) of all of the categories in this report (fig. 6B; table 1). Some of the GLA groundwater samples had relatively high percentages of $\mathrm{Na}$ and $\mathrm{Cl}$, and most of those samples were oxic, possibly because of shallow groundwater that had been affected to some extent by land use (deicing chemicals, septic use, urbanization, and agriculture). The sources of trace elements, aquifer geochemistry, and redox varied greatly within this aquifer group, in part because of the wide array of source rocks that affected the composition of the glacial sediments.

Mn exceeded the HBSL $(300 \mu \mathrm{g} / \mathrm{L})$ in about 20 percent of all water samples in the GLA-more than in samples from any other major aquifer group (table 10). This rate of exceedence may be related to the relatively high percentage of mixed and anoxic samples in the GLA as well as commonly low $\mathrm{pH}$ conditions (compare figs. 2, 3A, 6B, and 4N). Arsenic also is a common trace element with concentrations above HHBs in water samples from the GLA aquifer group, as are Al, B, $\mathrm{Fe}, \mathrm{Mo}, \mathrm{Rn}$, and $\mathrm{Sr}$. Arsenic occurred at concentrations above $10 \mu \mathrm{g} / \mathrm{L}$ in nearly 7 percent of 512 samples (table 10 ). $\mathrm{U}$ was greater than $30 \mu \mathrm{g} / \mathrm{L}$ in 0.5 percent of 640 samples, and most of these samples came from the west-central region, especially
North Dakota (table 10; fig. 4V). U concentrations in groundwater in this region may be related to the incorporation of uraniferous Cretaceous-age shale in the glacial sediments (Tourtelot, 1956; Seiler and others, 2003; Ayotte and others, 2007; Groschen and others, 2008). Groundwater samples from glacial sediments derived in part from crystalline rocks, primarily in Minnesota, had comparatively low $U$ concentrations. Arsenic, by contrast, appears to be more strongly related to geochemical controls such as redox and pH (Warner, 2001; Thomas, 2003, 2007).

$\mathrm{Mo}$ and $\mathrm{Sr}$ concentrations in water from wells in the GLA were above HBSLs in 2 and 1.2 percent of samples, respectively (table 10). These Mo samples were from groundwater primarily in the central portion of the GLA, including Illinois and Indiana (fig. 4O). Mo correlates most strongly with bicarbonate (rho equal to $0.58, p$ less than $0.001, N$ equal to 149 ), $\mathrm{Sr}$ (rho equal to $0.53, p$ less than $0.0001, N$ equal to 245 ), and As (rho equal to $0.47, p$ less than $0.0001, N$ equal to 470 ). Arsenic and Mo commonly occur as oxyanions in water and, as such, may be released by redox- or pH-driven desorption from mineral oxides. The correlation of As with Mo concentrations has been noted in studies of other areas in Illinois and Canada (Warner, 2001; Thomas, 2003). Sr concentrations were greatest in water samples in the east-central part of the GLA, primarily in Illinois, Indiana, and Ohio (fig. 4T). Sr is relatively insoluble in water except when it forms complexes with anions, such as sulfate or carbonate; in water samples from the GLA, Sr was correlated with bicarbonate (rho equal to 0.64 , $p$ less than $0.0001, N$ equal to 95 ) and sulfate (rho equal to $0.44, p$ less than $0.0001, N$ equal to 256 ). 


\section{Semiconsolidated Sand Aquifers (SCS)}

Groundwater samples from the SCS aquifer group consisted of a wide mix of water types (fig. 6C). Most samples from the SCS had either bicarbonate or $\mathrm{Cl}$ as the predominant anion, but some waters had a strong sulfate component. The bicarbonate-chloride-sulfate signature of these waters may be a reflection of the marine depositional history of these eastern and southern coastal plain sediments. Groundwater samples from the Northern Atlantic Coastal Plain aquifer system were predominantly of the sulfate type, whereas samples from the Mississippi Embayment aquifer system, Coastal Lowlands aquifer system, and the Texas Coastal uplands aquifer system were predominantly of the bicarbonate type.

The median $\mathrm{pH}$ of water samples from this aquifer group (5.5) was the lowest among all the aquifer groups (fig. 7); however, there was variability within this aquifer group. For example, the water samples from the Northern Atlantic Coastal Plain aquifer system and the Southeastern Coastal Plain aquifer system collectively had a median $\mathrm{pH}$ of 5.1, whereas the samples from the Coastal Lowlands aquifer system, Mississippi embayment aquifer system, and Texas coastal uplands aquifer system had median $\mathrm{pH}$ values of 6.6, 6.3 , and 7.6, respectively. Differences in $\mathrm{pH}$ may affect the solubility of certain trace elements.

In water samples from the SCS aquifer group, $\mathrm{Al}, \mathrm{Fe}, \mathrm{Pb}$, $\mathrm{Mn}$, and Rn concentrations were above current or proposed HHBs or nonhealth guidelines in 1 percent or more of samples (table 10). The greatest concentrations of $\mathrm{Al}, \mathrm{Fe}, \mathrm{Pb}$, and $\mathrm{Mn}$ were measured in water samples from the Northern Atlantic Coastal Plain and Southeastern Coastal Plain aquifer systems, where low $\mathrm{pH}$ values were likely to be a factor in their mobility (figs. 4A, K, L, and N). Concentrations of Co also were greatest in the water samples from the Northern Atlantic Coastal Plain aquifer system. The same was true for $\mathrm{Ni}$ and $\mathrm{Zn}$; these results were consistent with the low $\mathrm{pH}$ of the water in this aquifer (figs. 4I, P, and X).

Concentrations of As were greatest in water samples from the Coastal Lowlands and Northern Atlantic Coastal Plain aquifer systems of the SCS (figs. 3, 4C). Concentrations of U were below HHBs in all water samples from the SCS aquifers, but concentrations above $5 \mu \mathrm{g} / \mathrm{L}$ were found in water samples from the Coastal Lowlands, Southeastern Coastal Plain, and the Texas Coastal Uplands aquifer systems (figs. 3, 4V). Concentrations of $\mathrm{U}$ were correlated with concentrations of many dissolved ions; this correlation is consistent with mobilization by ion complexation, which occurs in other aquifer groups.

\section{Sandstone Aquifers (SAN)}

The sandstone aquifer group covers large areas of the east- and west-central parts of the United States (fig. 3A). The water type of samples from the SAN aquifers was variable but predominantly of the Ca-Mg-bicarbonate type. Some samples had a substantial percentage of $\mathrm{Na}$ and proportionally more sulfate (fig. 6D). Differences in water type may reflect differences in climate and (or) local differences in aquifer chemistry. The Na-dominated samples, for example, were mainly from the Lower Tertiary sandstone aquifers in Wyoming, where processes involving ion exchange of $\mathrm{Ca}$ for $\mathrm{Na}$ on aquifer materials and sulfate reduction may have been responsible for differences in water type (Bartos and others, 2005).

The $\mathrm{pH}$ of water samples from the SAN aquifers also varied locally with a median value of 7.3. Groundwater samples from Pennsylvanian aquifers and from the Woodbine aquifer (Dallas-Fort Worth metropolitan area) (fig. 3A) had substantially lower $\mathrm{pH}$ values (medians of 6.3 and 6.8 , respectively) than other SAN water samples. Groundwater samples from the Lower Tertiary aquifers (primarily in the Bighorn Basin) had a median $\mathrm{pH}$ of 8.1 and tended to be of the Na-bicarbonate type, which transitioned to Na-sulfate type as TDS increased (Bartos and others, 2005). The median TDS value for all of the water samples from the Lower Tertiary aquifers and the Woodbine aquifer was more than $1,300 \mathrm{mg} / \mathrm{L}$ (compared to less than $300 \mathrm{mg} / \mathrm{L}$ for all other SAN water samples).

Groundwater samples from the SAN aquifer group had eight elements (Al, As, Cd, Fe, Mn, Ni, Rn, and $\mathrm{Sr}$ ) with more than 1 percent of concentrations above current and proposed HHBs and nonhealth guidelines; however, percentages were less than 2 percent, except for $\mathrm{Fe}, \mathrm{Mn}, \mathrm{Ni}$, $\mathrm{Rn}$, and $\mathrm{Sr}$ (table 10). Concentrations of As were greatest in groundwater samples from the northeastern parts of the Early Mesozoic basin aquifers and the Valley and Ridge aquifers (75th-percentile value greater than $3 \mu \mathrm{g} / \mathrm{L}$ ) and also in the Woodbine aquifer and Lower Tertiary aquifers (75th-percentile value greater than $1 \mu \mathrm{g} / \mathrm{L}$ ). Concentrations of As from all samples were most strongly correlated with Mo (rho equal to $0.41, p$ less than $0.001, N$ equal to 256).

Concentrations of $U$ were greatest in the Woodbine aquifer, Early Mesozoic basin aquifers, and Lower Tertiary aquifers (75th-percentile value greater than $3 \mu \mathrm{g} / \mathrm{L}$ ). At the principal aquifer scale, sulfate, alkalinity, bicarbonate, specific conductance, and Mo are among the most significant correlates with U.

\section{Sandstone and Carbonate-Rock Aquifers (SCR)}

Groundwater samples from the SCR aquifer group - the Edwards-Trinity aquifer system in south-central Texas and the Mississippian aquifers primarily in Tennessee and Alabama were predominantly of the $\mathrm{Ca}-\mathrm{Mg}$-carbonate type (figs. $3 \mathrm{~A}$, $6 \mathrm{E})$. A few water samples, mostly from the Mississippian aquifers, had a Na-Cl component. The $\mathrm{pH}$ of waters from the SCR aquifers is variable, with the median from the Edwards-Trinity aquifer system (dry climate) equal to 7.0 and that from the Mississippian aquifers (humid climate) equal to 6.6 (fig. 7).

$\mathrm{Sr}$ exceeded the HBSL of $4,000 \mu \mathrm{g} / \mathrm{L}$ (table 10) in more than 25 percent of samples from the aquifers in SCRmuch greater than in other aquifer groups - however, these Sr concentrations were not evenly distributed across this aquifer group. For example, Sr concentrations exceeded the 
HBSL in about 10 percent of water samples from wells in the Edwards aquifer and in about 50 percent of water samples from the Trinity aquifer in south-central Texas (figs. 3, 4T). The source of the $\mathrm{Sr}$ is likely the argillaceous carbonate rocks that underlie the aquifer system (Oetting and others, 1996; Musgrove and Banner, 2004). Sr in groundwater samples from the Trinity aquifer correlated most strongly with specific conductance, sulfate, TDS, and K (rho equal to 0.64 to 0.55 , $p$ less than $0.001, N$ equal to 29). Median concentrations of $\mathrm{Rn}$ were near the USEPA-proposed MCL of $300 \mathrm{pCi} / \mathrm{L}$ in groundwater samples from the Trinity aquifer and about $150 \mathrm{pCi} / \mathrm{L}$ in groundwater samples from the Edwards aquifer. Median Rn concentrations groundwater samples from the Mississippian aquifers were about $600 \mathrm{pCi} / \mathrm{L}$.

\section{Carbonate-Rock Aquifers (CAR)}

Groundwater samples from wells in carbonate-rock aquifer group were predominantly of the $\mathrm{Ca}-\mathrm{Mg}$ bicarbonate type (fig. 6F). The chemistry of most samples indicated recharging groundwater (Ca bicarbonate) to evolved groundwater (dissolution of dolomite and gypsum) (Hanshaw and Back, 1979; Back and others, 1988).

Most of the groundwater samples were collected from these aquifers in humid parts of the United States, and very few elements (As, Fe, Mn, Rn) above current or proposed HHBs or nonhealth guidelines were detected (table 10). Al, $\mathrm{As}, \mathrm{Rn}, \mathrm{Sr}$, and $\mathrm{U}$ concentrations were elevated locally in the carbonate-rock aquifers. Al, for example, was above $50 \mu \mathrm{g} / \mathrm{L}$ in samples from only the Ozark Plateaus aquifer system, whereas As concentrations were greatest in the samples from the Biscayne aquifer and Floridan aquifer system. Rn was above the USEPA-proposed AMCL of $4,000 \mathrm{pCi} / \mathrm{L}$ in only one groundwater sample from the Floridan aquifer system, but median concentrations exceeded the USEPA-proposed MCL of $300 \mathrm{pCi} / \mathrm{L}$ in most of the samples from this aquifer group.

$\mathrm{Sr}$, a common element in carbonate-aquifer waters, was analyzed in water samples from the carbonate rocks of only the Valley and Ridge aquifers and Biscayne aquifers. The 95th-percentile value for $\mathrm{Sr}$ in these samples exceeded $1,000 \mu \mathrm{g} / \mathrm{L}$, and the median in water samples from the Biscayne aquifer was greater than $750 \mu \mathrm{g} / \mathrm{L}$. U also occurred in some water samples in the Biscayne aquifer, with the 95th-percentile value exceeding 24 and $15 \mu \mathrm{g} / \mathrm{L}$ in samples collected from shallow and deep positions in the aquifer, respectively.

By contrast, As concentrations in 30 groundwater samples from a dry-region carbonate aquifer in the Great Basin (Nevada and Utah) ranged from 0.7 to $45.7 \mu \mathrm{g} / \mathrm{L}$ with a median value of $9.7 \mu \mathrm{g} / \mathrm{L}$ (Schaefer and others, 2006). Processes identified as leading to the mobilization of As in groundwater include geothermal heating and long time of travel along a flow path. For example, in the central part of this carbonate-rock aquifer, groundwater flow is generally from north to south, and As concentrations also increase in this direction (Schaefer and others, 2006).

\section{Basaltic- and other Volcanic-Rock Aquifers (BAV)}

The fewest groundwater samples were collected from the BAV aquifer group, partly because of the smaller areal distribution of these deposits. Fewer than 100 water samples were collected for each trace element except $\mathrm{Fe}$ ( $N$ equal to 232 ) and $\mathrm{Mn}$ ( $N$ equal to 228) (table 10). The water type of the groundwater samples from BAV aquifer group was mixed but tended toward either $\mathrm{Ca}-\mathrm{Mg}$ bicarbonate or $\mathrm{Ca}-\mathrm{Mg}$ chloride (fig. 6G). The median $\mathrm{pH}$ of water samples from this aquifer group (7.7) was the highest among the aquifer groups in this report (fig. 7). The $\mathrm{pH}$ of water in these aquifers may be increased by processes such as silicate hydrolysis and carbonic acid weathering (Wood and Fernandez, 1988). The former process results in the addition of hydroxyl ions to the water, raising the $\mathrm{pH}$, whereas in the latter, bicarbonate ions are added. Ion exchange of $\mathrm{Na}$ for $\mathrm{Ca}$ can further increase the dissolution of calcite, resulting in still higher $\mathrm{pH}$ (Wood and Fernandez, 1988). The water samples from the BAV aquifer group had only four elements above HHBs or nonhealth guidelines (table 10), although As was found above $10 \mu \mathrm{g} / \mathrm{L}$ in 6.2 percent of water samples (all from the Upper Snake River basin), and $\mathrm{Rn}$ was above the USEPA-proposed MCL of $300 \mathrm{pCi} / \mathrm{L}$ in 43 percent of water samples (table 10).

\section{Crystalline-Rock Aquifers (CRL)}

The water type of samples from the CRL aquifer group was predominantly $\mathrm{Ca}$ bicarbonate to mixed $\mathrm{Ca}-\mathrm{Mg}-\mathrm{Na}$ bicarbonate, but with some samples having a stronger $\mathrm{Na}-\mathrm{Cl}$ influence (fig. 6H). The median $\mathrm{pH}$ of water samples from crystalline-rock aquifers was about 6.5 (fig. 7); however, $\mathrm{pH}$ was slightly alkaline (7.3) in New York and New England and the Rocky Mountain Front Range crystalline-rock aquifers, and somewhat acidic (5.9) for the Piedmont and Blue Ridge crystalline-rock aquifers. This variation was evident from the large interquartile range for $\mathrm{pH}(1.6 \mathrm{pH}$ units) for the CRL water samples (fig. 7). Concentrations of six elements (Al, As, $\mathrm{Fe}, \mathrm{Mn}, \mathrm{Rn}$, and $\mathrm{U}$ ) were greater than HHBs and nonhealth guidelines in at least 1 percent of the groundwater samples from the CRL aquifer group (table 10). Arsenic exceedences of HHBs in the CRL were 5.4 percent but jumped to 17 percent in samples from the CRL aquifers in the eastern part of New England. U was greatest in groundwater from CRL aquifers in the Northeast (New York and New England) and the Rocky Mountain Front Range (95th-percentile values of 18 and $220 \mu \mathrm{g} / \mathrm{L}$, respectively), whereas 95th-percentile concentrations in samples from the Piedmont and Blue Ridge CRL aquifers ranged from 1.9 to $6.7 \mu \mathrm{g} / \mathrm{L}$. Water from the CRL aquifers had the greatest $\mathrm{Rn}$ concentrations of any aquifer group. For example, 92 percent of Rn concentrations from this aquifer group were greater than the USEPA-proposed MCL of $300 \mathrm{pCi} / \mathrm{L}$, and 28 percent of concentrations from CRL samples were greater than the USEPA-proposed AMCL of 
4,000 pCi/L (table 10; appendix 3). Rn concentrations were, by far, greater in the water samples from CRL aquifers in New York and New England (fig. 4Q).

Concentrations of As in water samples from the CRL were correlated most strongly with $\mathrm{pH}$ (rho equal to 0.32 , $p$ less than $0.0001, N$ equal to 223) and redox as indicated by DO concentration (rho equal to $-0.34, p$ less than 0.0001 , $N$ equal to 221). $\mathrm{U}$ in the samples from the CRL aquifers was correlated with many water-quality and well-construction parameters, including $\mathrm{Mo}, \mathrm{Ca}, \mathrm{pH}$, specific conductance, TDS, $\mathrm{Na}$, and well depth, collectively indicating possible complexation of $U$ with bicarbonate. $U$ concentrations were also correlated with $\mathrm{Rn}$ in the CRL aquifers, but Rn was correlated with no other elements at the aquifer-group level. In water from the CRL aquifers in New York and New England, however, $\mathrm{Rn}$ correlated weakly with $\mathrm{Pb}$ (rho equal to $0.38, p$ less than $0.0005, N$ equal to 82 ).

\section{Relation of Selected Trace Elements to $\mathrm{pH}$ and Redox State}

The effects of redox and $\mathrm{pH}$ account for substantial additional variability in the concentrations of trace elements in groundwater among the major aquifer groups. Other factors such as water type, TDS, organic matter, and biological activity also may influence trace-element concentrations and may account for unexplained variability in the expected redoxand $\mathrm{pH}$-related behavior of some trace elements. Most trace elements are sensitive to redox conditions in groundwater, either because that element can occupy multiple redox states in natural waters, or because the redox state controls the concentration of soluble complexes. Variation in $\mathrm{pH}$ has an effect on the adsorption of many trace elements, as well as on the solubility of some concentration-limited hydroxide solid phases (such as Fe and Mn). Some redox-sensitive trace elements are more mobile under low $\mathrm{pH}$ and oxic conditions. For example, $\mathrm{Cd}, \mathrm{Cu}, \mathrm{Pb}$, and $\mathrm{Zn}$ can increase from 0 to 100 percent adsorption on oxide-hydroxides over a $\mathrm{pH}$ range of 2 standard units (Salbu and Steinnes, 1994). Other elements, such as $\mathrm{Fe}$ and $\mathrm{Mn}$, are mobile under low $\mathrm{pH}$ and (or) anoxic conditions. Some oxyanion-forming trace elements, by contrast, are generally more mobile under high $\mathrm{pH}$ conditions and include As, $\mathrm{Cr}, \mathrm{Mo}, \mathrm{Se}$, and V. Arsenic sorption, for example, decreases as $\mathrm{pH}$ increases (Smedley and Kinniburgh, 2002; Stollenwerk, 2003).

In this report, groundwater samples are classified into three simplified redox states: oxic, mixed, and anoxic (table 2) based on a scheme that uses commonly measured ions and properties of the water sample to assess the redox state (Chapelle and others, 1995; Chapelle and others, 2002; Paschke, 2007; McMahon and Chapelle, 2008; McMahon and others, 2009). Most samples were oxic according to this scheme (fig. 2A). About 70 percent or more of the water samples in the USG, SCR, CAR, BAV, and CRL aquifer groups were classified as oxic. By contrast, more than 50 percent of groundwater samples in the GLA, SCS, and SAN aquifer groups were classified as mixed or anoxic (table 1). Generally, anoxic and mixed redox conditions were more common in well water in the humid parts of the United States, whereas oxic conditions were more common in well water in the dry regions (fig. 2A). Additional information on $\mathrm{Fe}$ and other trace-element guideline exceedences for categories of $\mathrm{pH}$ and redox are shown in appendix 4.

The median $\mathrm{pH}$ varies by aquifer group and is above or equal to 7 for the samples from the USG, GLA, SAN, CAR, and BAV groups and below 7 for the samples from the SCS, $\mathrm{SCR}$, and CRL groups (fig. 7). The $\mathrm{pH}$ of precipitation is lower in the eastern part of the United States than in the west (fig. 2B), and acidification of groundwater from external factors, such as acid deposition related to increased fossil-fuel burning, can be associated with the mobility of trace metals in recently recharged (post-1960) groundwater (Jacks, 1993).

\section{Iron and Manganese}

Based on the redox classification scheme used in this report, samples with high $\mathrm{Fe}$ or $\mathrm{Mn}$ (concentrations greater than 0.1 or $0.05 \mathrm{mg} / \mathrm{L}$, respectively) were considered to be anoxic (table 2). Therefore, Fe and Mn occurred most often in mixed and anoxic samples and least often in oxic samples (figs. 8K, N). For samples with data sufficient for the inference of redox status, 19 percent had DO less than or equal to $0.5 \mathrm{mg} / \mathrm{L}$ and high $\mathrm{Fe} / \mathrm{Mn}, 62$ percent had low Fe/Mn and DO greater than $0.5 \mathrm{mg} / \mathrm{L}$, and 19 percent had high Fe/Mn and DO greater than $0.5 \mathrm{mg} / \mathrm{L}$. Thus, 81 percent of the time, Fe $/ \mathrm{Mn}$ and DO were mutually exclusive under the above conditions.

\section{Aluminum, Copper, Lead, and Zinc}

$\mathrm{Al}, \mathrm{Cu}, \mathrm{Pb}$, and $\mathrm{Zn}$ are common elements in the environment and are found in materials and products used in drinkingwater-well construction and plumbing. It is therefore difficult to determine the extent to which the concentrations of these elements in water samples from drinking-water wells are related to these materials or to other sources. Additionally, bias caused by systematic contamination of samples was identified for $\mathrm{Al}$ and $\mathrm{Zn}$ through analysis of water initially free of these elements (Apodaca and others, 2006). Thus, results from analyses of these elements at concentrations near the reporting levels must be considered in light of the potential bias.

Redox effects on trace-element occurrence and distribution are often, but not always, similar among the major aquifer groups. In groundwater samples from the USG, $\mathrm{Al}$ occurrence generally increased as samples became more anoxic in both $\mathrm{pH}$ categories (figs. 8A and 9A). Al exceeded the nonhealth 
guideline in up to 3 percent of water samples from the major aquifer groups and most commonly exceeded guidelines under low-pH and mixed or anoxic conditions (table 10). $\mathrm{Cu}$ also was sensitive to redox and $\mathrm{pH}$, occurring more frequently under low-pH and oxic conditions in about half of the aquifer groups (fig. $8 \mathrm{~J}$ ). $\mathrm{Pb}$, based on solubility considerations, is more mobile under low-pH conditions (Hem, 1985), and this was true for most water samples (figs. 9B and 8L).

Additional variation in redox and $\mathrm{pH}$ effects within the same aquifer group may be related to climate. For example, in the humid-region USG aquifers, $\mathrm{Pb}$ in groundwater occurred more frequently and was more strongly redox controlled in the high-pH samples than in the low-pH samples (fig. 10B). In the dry-region USG aquifers, redox and $\mathrm{pH}$ effects for groundwater $\mathrm{Pb}$ occurrence were less discernible. Further, $\mathrm{Cu}$ occurrence in groundwater was not sensitive to $\mathrm{pH}$ in either region but was redox sensitive in humid-region samples (fig. 10C). $\mathrm{Zn}$ occurrence in groundwater showed a clear sensitivity to redox in the humid-region USG aquifers but not in dry-region aquifers (fig. 10D).

\section{Arsenic, Chromium, Molybdenum, and Selenium}

As, Cr, Mo, and Se commonly form oxyanions in groundwater that are affected by redox and $\mathrm{pH}$, and thus the chemical behavior of these elements is somewhat predictable. The percentage of samples with As, for example, generally increased from oxic to anoxic redox conditions when $\mathrm{pH}$ was less than 7 , but was consistently greater than 50 percent when $\mathrm{pH}$ was greater than or equal to 7 (fig. 11A). A similar pattern was seen for Mo (fig. 11C) and, to a lesser extent, $\mathrm{Cr}$ (fig. 11B). The pattern was opposite and applied in both $\mathrm{pH}$ categories for $\mathrm{Se}$, which is more soluble under oxic conditions (fig. 11D). For $\mathrm{As}, \mathrm{Cr}$, and Mo, the lack of redox sensitivity at high $\mathrm{pHs}$ may be related to $\mathrm{pH}$-driven desorption or ion competition, which either obscures or reduces the redox effects that were seen in the low-pH samples.

Some deviation from these general patterns occurred by aquifer group and by aquifer, but the general patterns may indicate the relative importance of different processes in specific aquifer settings. For example, in the GLA aquifer group, As concentrations and occurrence increased significantly as samples became increasingly anoxic and as $\mathrm{pH}$ increased (figs. 12A and B). These results are similar to findings from other regional studies (Thomas, 2007). For groundwater samples from the USG aquifer group, however, As occurrence increased significantly as $\mathrm{pH}$ increased, but only for oxic and mixed conditions (figs. $12 \mathrm{C}$ and $\mathrm{D}$ ). In the high-pH USG samples, there were no differences in the groundwater As concentrations or occurrence rates among redox categories. This result suggests that As mobility in some settings may be less controlled by redox when $\mathrm{pH}$ is greater than 7 .
Occurrences of Mo and to some extent $\mathrm{Cr}$ in groundwater from the GLA aquifer group also increased as the water became more anoxic for both low- and high-pH samples (figs. $8 \mathrm{H}, \mathrm{O}, 11 \mathrm{~B}$ and $\mathrm{C}$ ). Se occurrence, by contrast, dropped off sharply from oxic and mixed to anoxic water samples (figs. 8R, 11D). Se occurred at concentrations greater than $1 \mu \mathrm{g} / \mathrm{L}$ in fewer than 30 percent of water samples from most aquifer groups except the USG group, from which concentrations in as many as half of the samples in the oxic or mixed categories were greater than $1 \mu \mathrm{g} / \mathrm{L}$ (fig. 8R). This result is consistent with results from studies in the San Joaquin Valley in California, where Se mobility was greater under oxic conditions (Dubrovsky and others, 1993; Fujii and Swain, 1995). These studies showed that Se was controlled by redox conditions, with only selenate $\left(\mathrm{SeO}_{4}^{2-}\right)$ being mobile under oxic conditions. B, and to some extent $\mathrm{V}$, appeared redox sensitive (figs. $8 \mathrm{~F}, \mathrm{~W}$ ) and generally followed the behavior of As and Mo (figs. 8C, O).

\section{Uranium and Radon}

$\mathrm{U}$ occurrence in groundwater was redox and $\mathrm{pH}$ dependent, occurring most frequently in samples with oxic or mixed redox conditions and generally under high-pH conditions (fig. 8V). However, because U can form soluble complexes under a wide range of redox and $\mathrm{pH}$ conditions that are common in groundwater across the United States, $\mathrm{U}$ also is sometimes found in water samples that are characterized as anoxic and low $\mathrm{pH}$, possibly because of ion complexation or competition.

Concentrations of Rn, a nonreactive gas, showed relations to redox and (or) $\mathrm{pH}$ conditions in the water samples from several aquifer groups. In general, Rn occurred most often in low-pH, oxic water samples. In groundwater from the CRL aquifer group, Rn occurrence was nearly ubiquitous, owing to the abundant U-bearing minerals in the rocks of the region and to the associated presence of radium $\left({ }^{226} \mathrm{Ra}\right.$, which decays directly to $\mathrm{Rn}$ ) on or near fracture surfaces. In groundwater samples from the GLA aquifer group, however, both redox and $\mathrm{pH}$ were related to occurrence (fig. 8Q). The apparent redox relation may be due in part to the decreased solubility of ${ }^{226} \mathrm{Ra}$ in oxic groundwater conditions. This suggests that the source strength and (or) emanation efficiency for radon is possibly enhanced in the shallow part of the aquifer, perhaps due to greater weathering of radionuclides from aquifer materials or the flushing or depletion of sources of radon $\left({ }^{226} \mathrm{Ra}\right)$ in the deeper parts of the aquifer. Oxic, low-pH groundwater conditions are consistent with the relative immobility of ${ }^{226} \mathrm{Ra}$ in the shallow aquifer and the possible depletion of ${ }^{226} \mathrm{Ra}$ in the deeper, anoxic parts of the aquifer. Decreased solubility would favor adsorption of ${ }^{226} \mathrm{Ra}$ and provide a source for the generation of Rn (Focazio and others, 2001). 

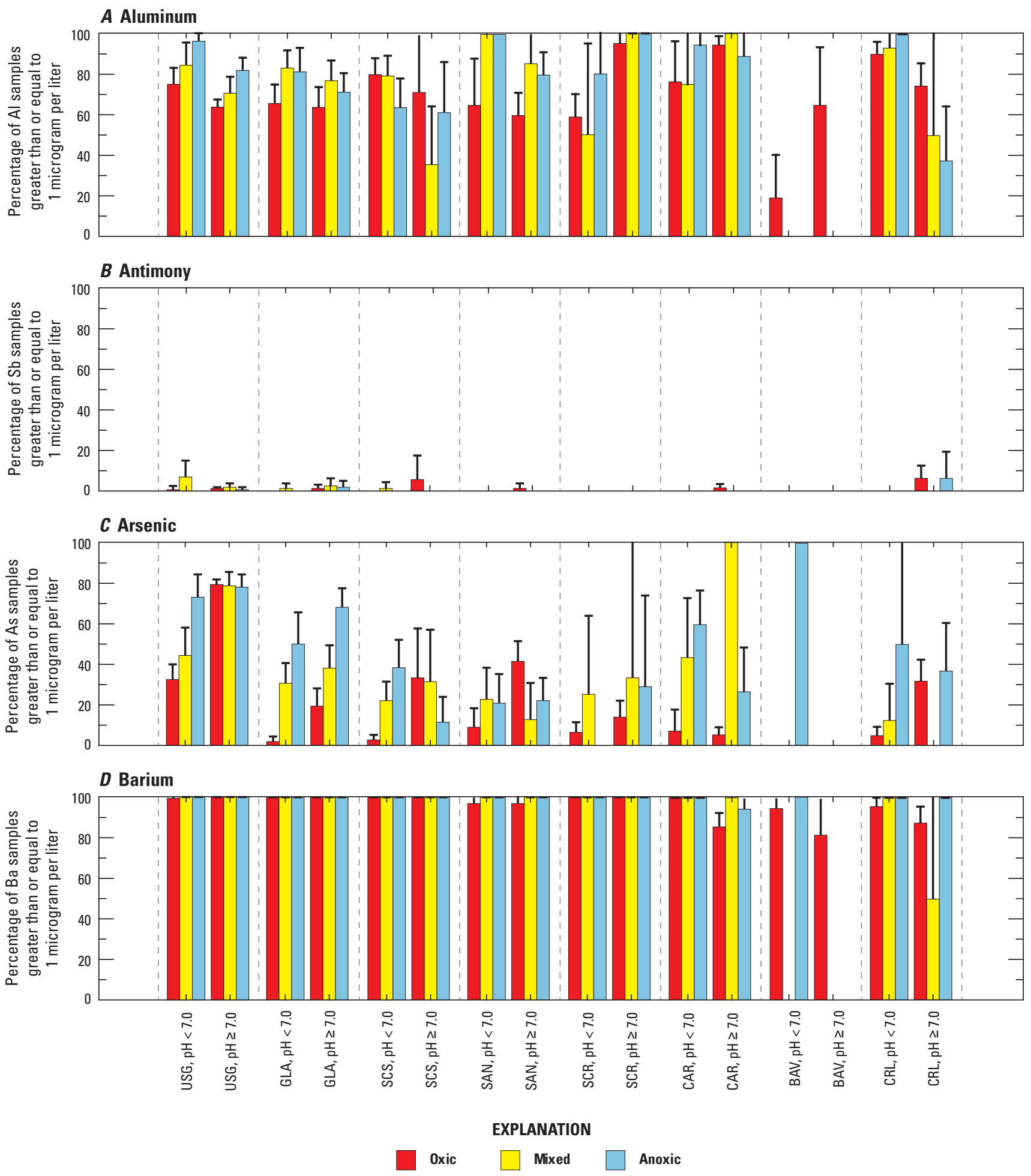

Figure 8. The percentage of groundwater samples with trace-element concentrations greater than or equal to the reporting level, by redox and $\mathrm{pH}$ categories, for the major aquifer groups: $(A)$ aluminum, $(B)$ antimony, $(C)$ arsenic, $(D)$ barium, $(E)$ beryllium, $(F)$ boron, $(G)$ cadmium, $(H)$ chromium, (I) cobalt, $(J)$ copper, $(K)$ iron, $(L)$ lead, $(M)$ lithium, $(N)$ manganese, $(O)$ molybdenum, $(P)$ nickel, $(Q)$ radon, $(R)$ selenium, $(S)$ silver, $(T)$ strontium, $(U)$ thallium, $(V)$ uranium, $(W)$ vanadium, and $(X)$ zinc. Reporting level is 1 microgram per liter unless otherwise noted. USG, unconsolidated sand and gravel aquifers; GLA, glacial unconsolidated sand and gravel aquifers; SCS, semiconsolidated sand aquifers; SAN, sandstone aquifers; SCR, sandstone and carbonate-rock aquifers; CAR, carbonate-rock aquifers; $\mathrm{BAV}$, basaltic- and other volcanic-rock aquifers; and CRL, crystalline-rock aquifers. Error bars represent the 95-percent confidence interval of the mean (binomial distribution). See appendix 4 for the number of samples in each category. 

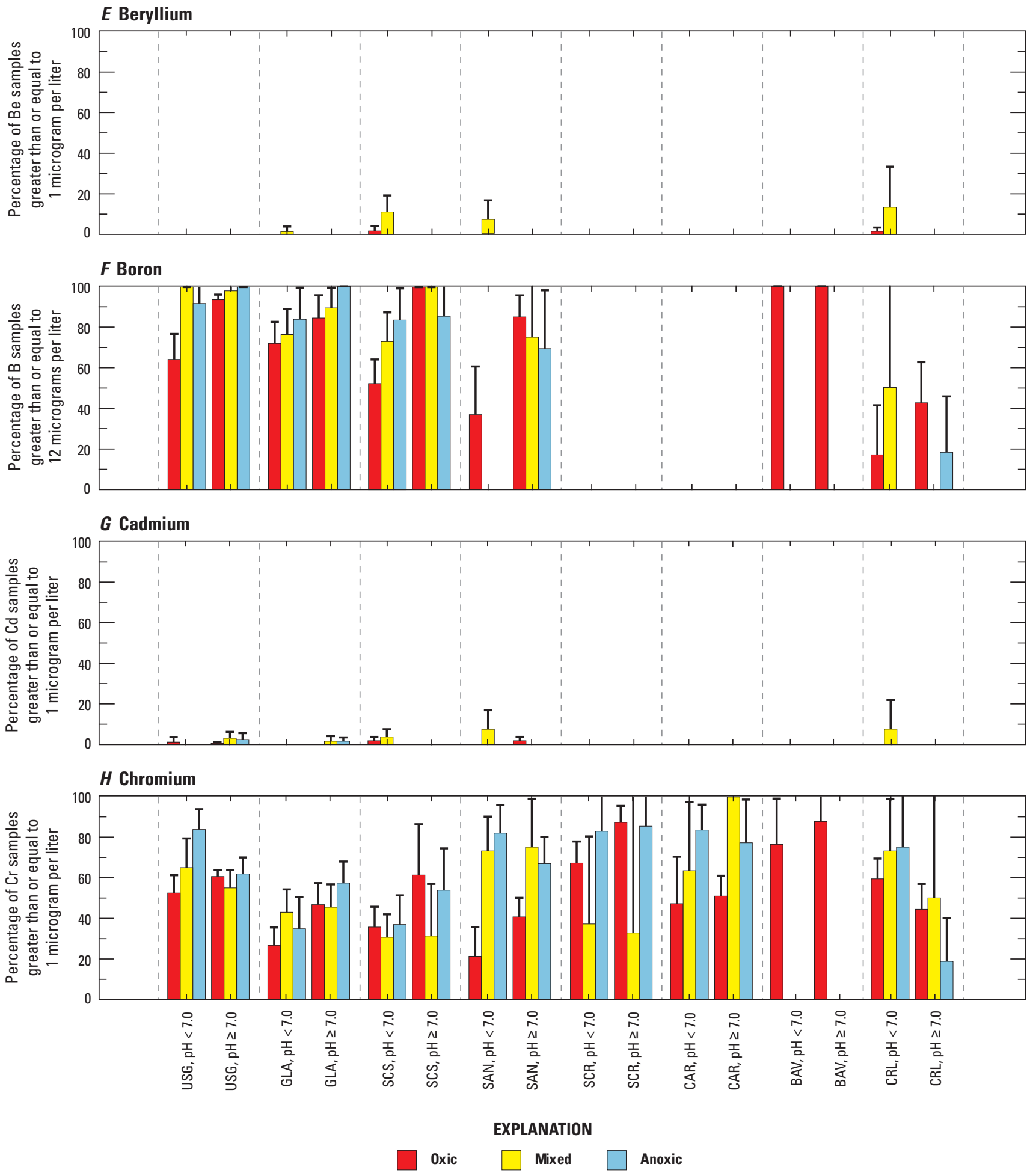

Figure 8. The percentage of groundwater samples with trace-element concentrations greater than or equal to the reporting level, by redox and $\mathrm{pH}$ categories, for the major aquifer groups: $(A)$ aluminum, $(B)$ antimony, $(C)$ arsenic, $(D)$ barium, $(E)$ beryllium, $(F)$ boron, $(G)$ cadmium, (H) chromium, (I) cobalt, $(J)$ copper, $(K)$ iron, $(L)$ lead, $(M)$ lithium, $(N)$ manganese, $(O)$ molybdenum, $(P)$ nickel, $(Q)$ radon, $(R)$ selenium, $(S)$ silver, $(T)$ strontium, $(U)$ thallium, $(V)$ uranium, $(W)$ vanadium, and $(X)$ zinc. Reporting level is 1 microgram per liter unless otherwise noted. USG, unconsolidated sand and gravel aquifers; GLA, glacial unconsolidated sand and gravel aquifers; SCS, semiconsolidated sand aquifers; SAN, sandstone aquifers; SCR, sandstone and carbonate-rock aquifers; CAR, carbonate-rock aquifers; BAV, basaltic- and other volcanic-rock aquifers; and CRL, crystalline-rock aquifers. Error bars represent the 95-percent confidence interval of the mean (binomial distribution). See appendix 4 for the number of samples in each category.-Continued 

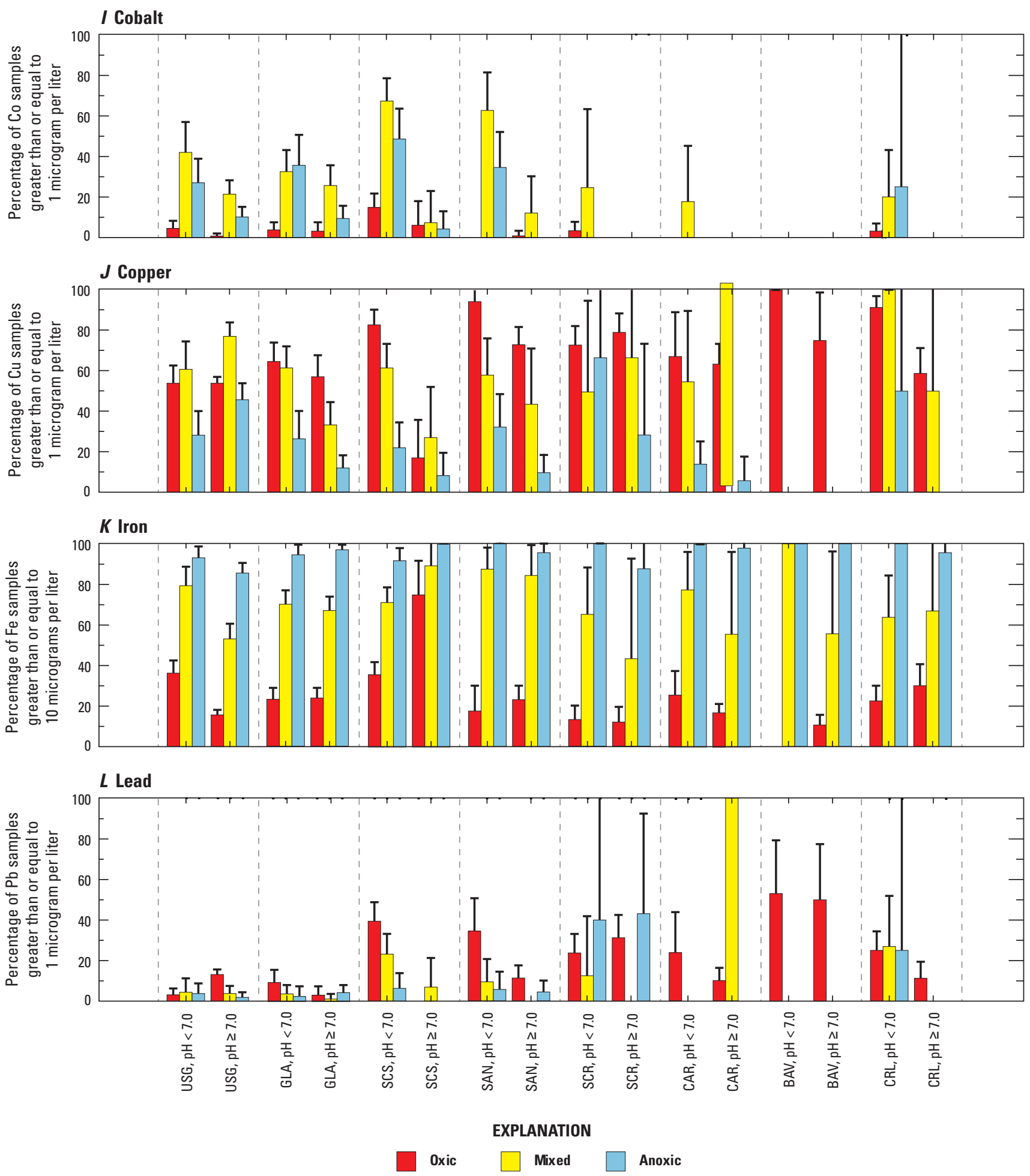

Figure 8. The percentage of groundwater samples with trace-element concentrations greater than or equal to the reporting level, by redox and $\mathrm{pH}$ categories, for the major aquifer groups: $(A)$ aluminum, $(B)$ antimony, $(C)$ arsenic, $(D)$ barium, $(E)$ beryllium, $(F)$ boron, $(G)$ cadmium, (H) chromium, (I) cobalt, $(J)$ copper, $(K)$ iron, $(L)$ lead, $(M)$ lithium, $(N)$ manganese, $(O)$ molybdenum, $(P)$ nickel, $(Q)$ radon, $(R)$ selenium, $(S)$ silver, $(T)$ strontium, $(U)$ thallium, $(V)$ uranium, $(W)$ vanadium, and $(X)$ zinc. Reporting level is 1 microgram per liter unless otherwise noted. USG, unconsolidated sand and gravel aquifers; GLA, glacial unconsolidated sand and gravel aquifers; SCS, semiconsolidated sand aquifers; SAN, sandstone aquifers; SCR, sandstone and carbonate-rock aquifers; CAR, carbonate-rock aquifers; BAV, basaltic- and other volcanic-rock aquifers; and CRL, crystalline-rock aquifers. Error bars represent the 95-percent confidence interval of the mean (binomial distribution). See appendix 4 for the number of samples in each category.-Continued 

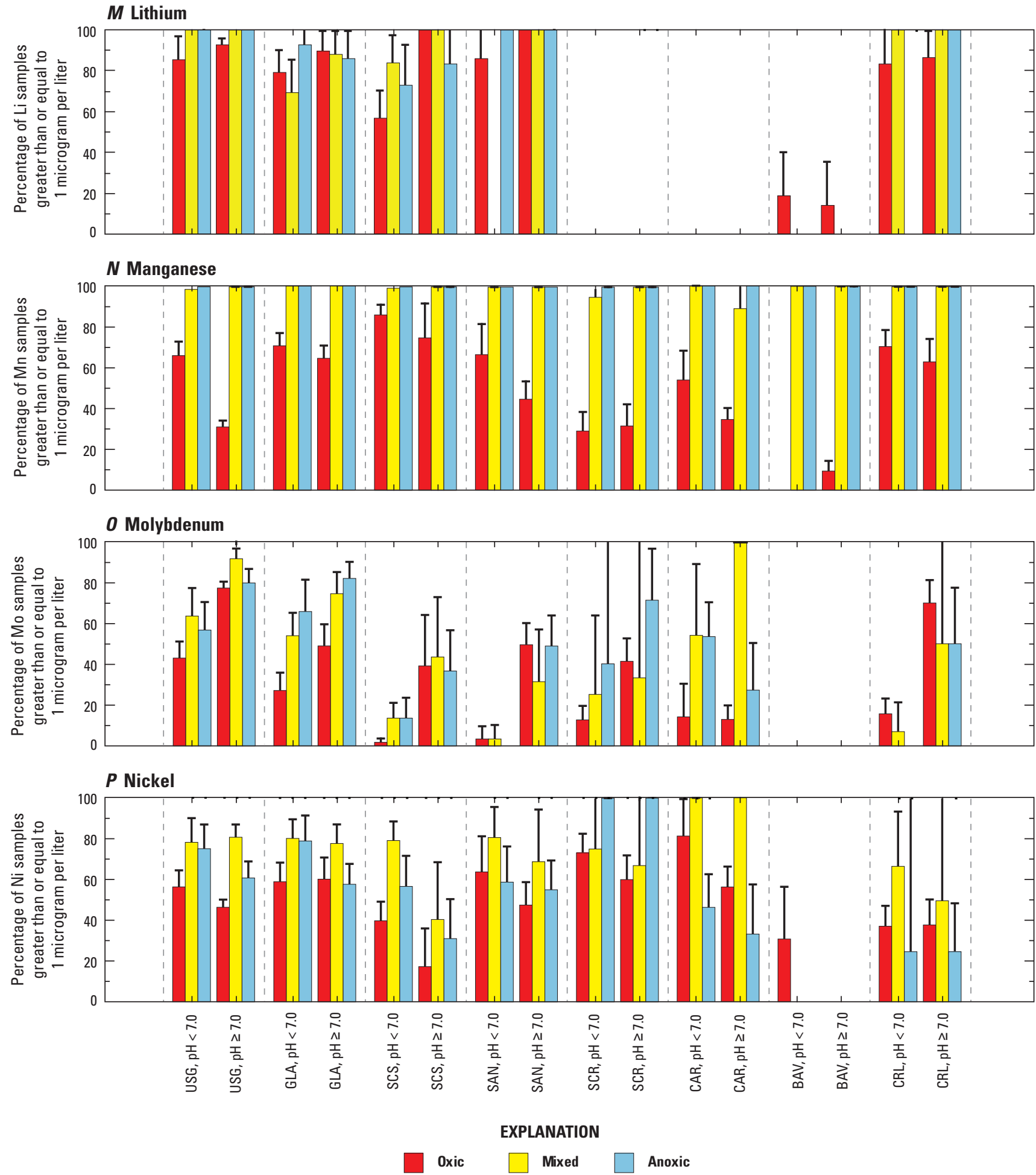

Figure 8. The percentage of groundwater samples with trace-element concentrations greater than or equal to the reporting level, by redox and $\mathrm{pH}$ categories, for the major aquifer groups: $(A)$ aluminum, $(B)$ antimony, $(C)$ arsenic, $(D)$ barium, $(E)$ beryllium, $(F)$ boron, $(G)$ cadmium, $(H)$ chromium, $(I)$ cobalt, $(J)$ copper, $(K)$ iron, $(L)$ lead, $(M)$ lithium, $(N)$ manganese, $(O)$ molybdenum, $(P)$ nickel, $(Q)$ radon, $(R)$ selenium, $(S)$ silver, $(T)$ strontium, $(U)$ thallium, $(V)$ uranium, $(W)$ vanadium, and $(X)$ zinc. Reporting level is 1 microgram per liter unless otherwise noted. USG, unconsolidated sand and gravel aquifers; GLA, glacial unconsolidated sand and gravel aquifers; SCS, semiconsolidated sand aquifers; SAN, sandstone aquifers; SCR, sandstone and carbonate-rock aquifers; CAR, carbonate-rock aquifers; BAV, basaltic- and other volcanic-rock aquifers; and CRL, crystalline-rock aquifers. Error bars represent the 95-percent confidence interval of the mean (binomial distribution). See appendix 4 for the number of samples in each category.-Continued 

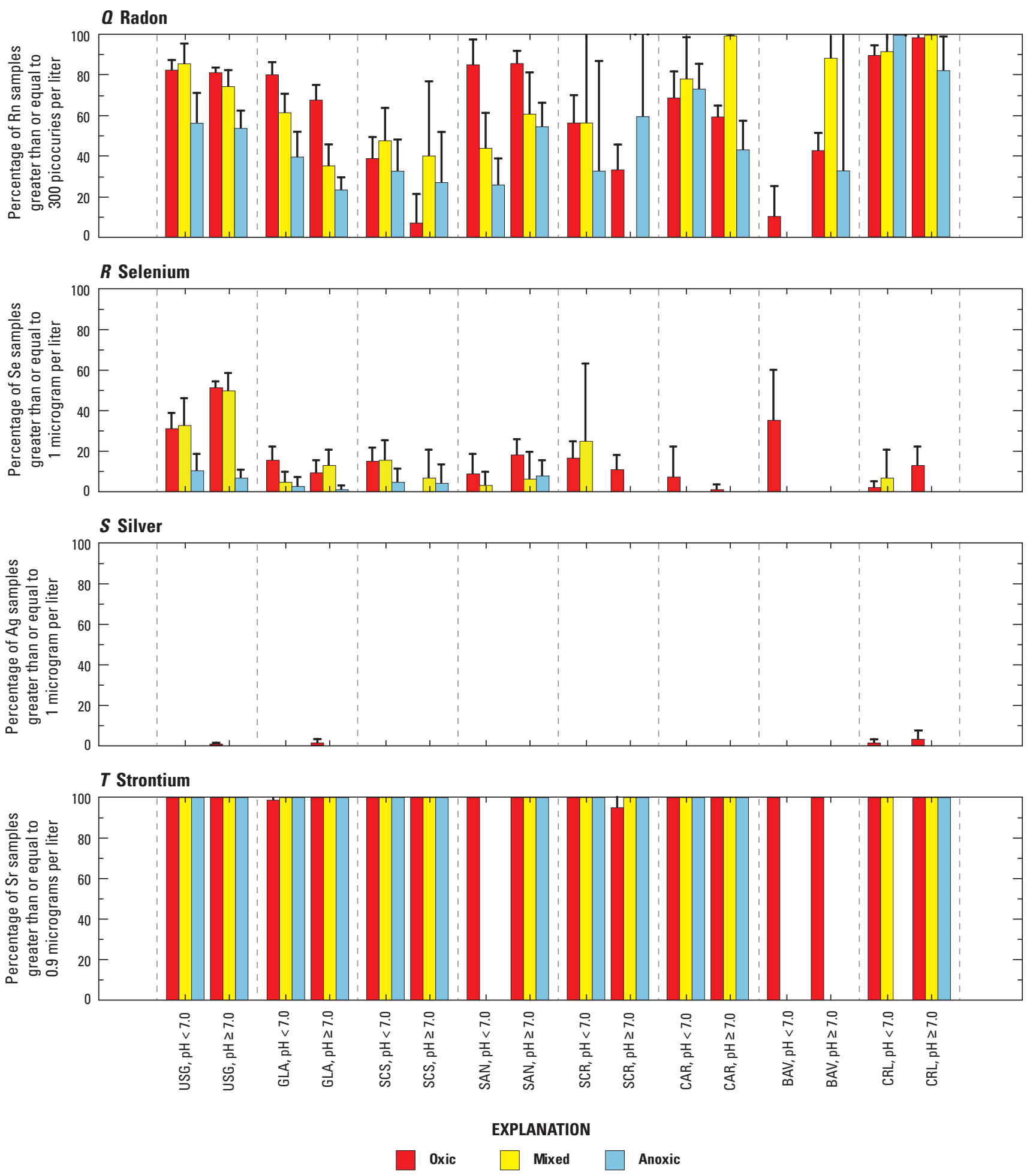

Figure 8. The percentage of groundwater samples with trace-element concentrations greater than or equal to the reporting level, by redox and $\mathrm{pH}$ categories, for the major aquifer groups: $(A)$ aluminum, $(B)$ antimony, $(C)$ arsenic, $(D)$ barium, $(E)$ beryllium, $(F)$ boron, $(G)$ cadmium, (H) chromium, (I) cobalt, $(J)$ copper, $(K)$ iron, $(L)$ lead, $(M)$ lithium, $(N)$ manganese, $(O)$ molybdenum, $(P)$ nickel, $(Q)$ radon, $(R)$ selenium, $(S)$ silver, $(T)$ strontium, $(U)$ thallium, $(V)$ uranium, $(W)$ vanadium, and $(X)$ zinc. Reporting level is 1 microgram per liter unless otherwise noted. USG, unconsolidated sand and gravel aquifers; GLA, glacial unconsolidated sand and gravel aquifers; SCS, semiconsolidated sand aquifers; SAN, sandstone aquifers; SCR, sandstone and carbonate-rock aquifers; CAR, carbonate-rock aquifers; BAV, basaltic- and other volcanic-rock aquifers; and CRL, crystalline-rock aquifers. Error bars represent the 95-percent confidence interval of the mean (binomial distribution). See appendix 4 for the number of samples in each category.-Continued 

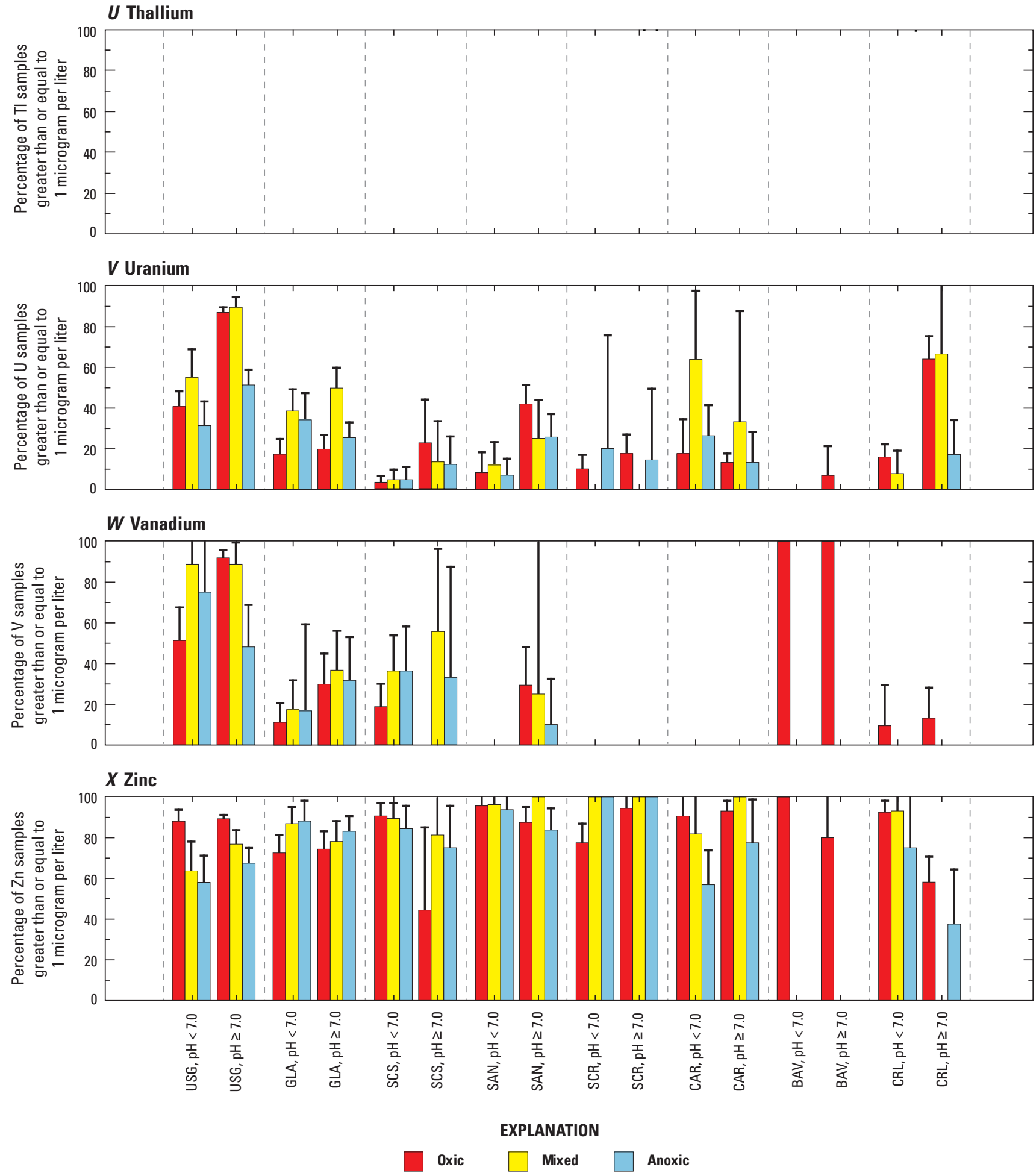

Figure 8. The percentage of groundwater samples with trace-element concentrations greater than or equal to the reporting level, by redox and $\mathrm{pH}$ categories, for the major aquifer groups: $(A)$ aluminum, $(B)$ antimony, $(C)$ arsenic, $(D)$ barium, $(E)$ beryllium, $(F)$ boron, $(G)$ cadmium, $(H)$ chromium, $(I)$ cobalt, $(J)$ copper, $(K)$ iron, $(L)$ lead, $(M)$ lithium, $(N)$ manganese, $(O)$ molybdenum, $(P)$ nickel, $(Q)$ radon, $(R)$ selenium, $(S)$ silver, $(T)$ strontium, $(U)$ thallium, $(V)$ uranium, $(W)$ vanadium, and $(X)$ zinc. Reporting level is 1 microgram per liter unless otherwise noted. USG, unconsolidated sand and gravel aquifers; GLA, glacial unconsolidated sand and gravel aquifers; SCS, semic onsolidated sand aquifers; SAN, sandstone aquifers; SCR, sandstone and carbonate-rock aquifers; CAR, carbonate-rock aquifers; BAV, basaltic- and other volcanic-rock aquifers; and CRL, crystalline-rock aquifers. Error bars represent the 95-percent confidence interval of the mean (binomial distribution). See appendix 4 for the number of samples in each category.-Continued 


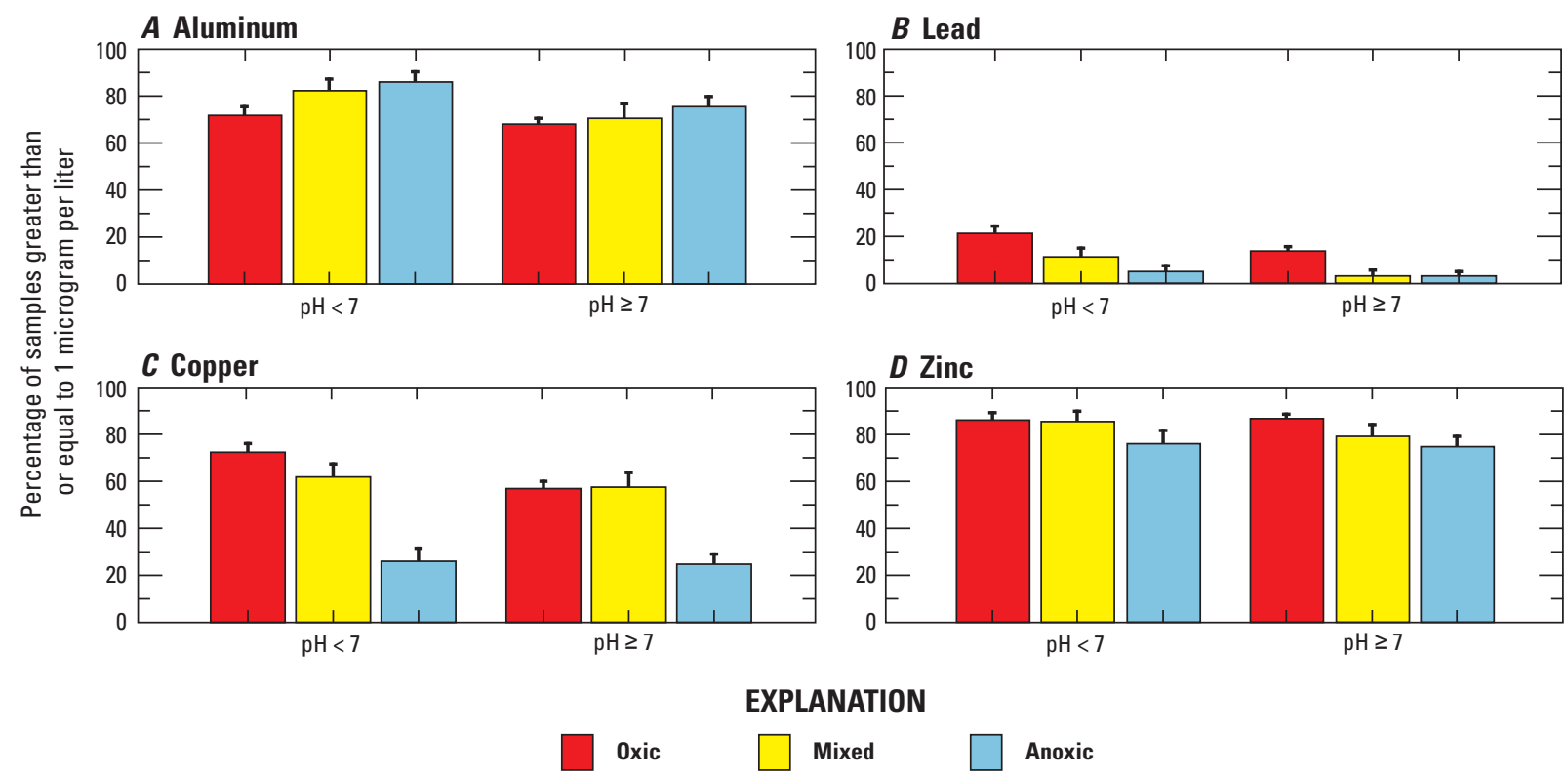

Figure 9. The percentages of groundwater samples with trace-element concentrations greater than or equal to 1 microgram per liter for $(A)$ aluminum, $(B)$ lead, $(C)$ copper, and $(D)$ zinc, by $\mathrm{pH}$ and redox category. Error bars represent the 95-percent confidence interval of the mean (binomial distribution). $<$, less than; $\geq$, greater than or equal to.

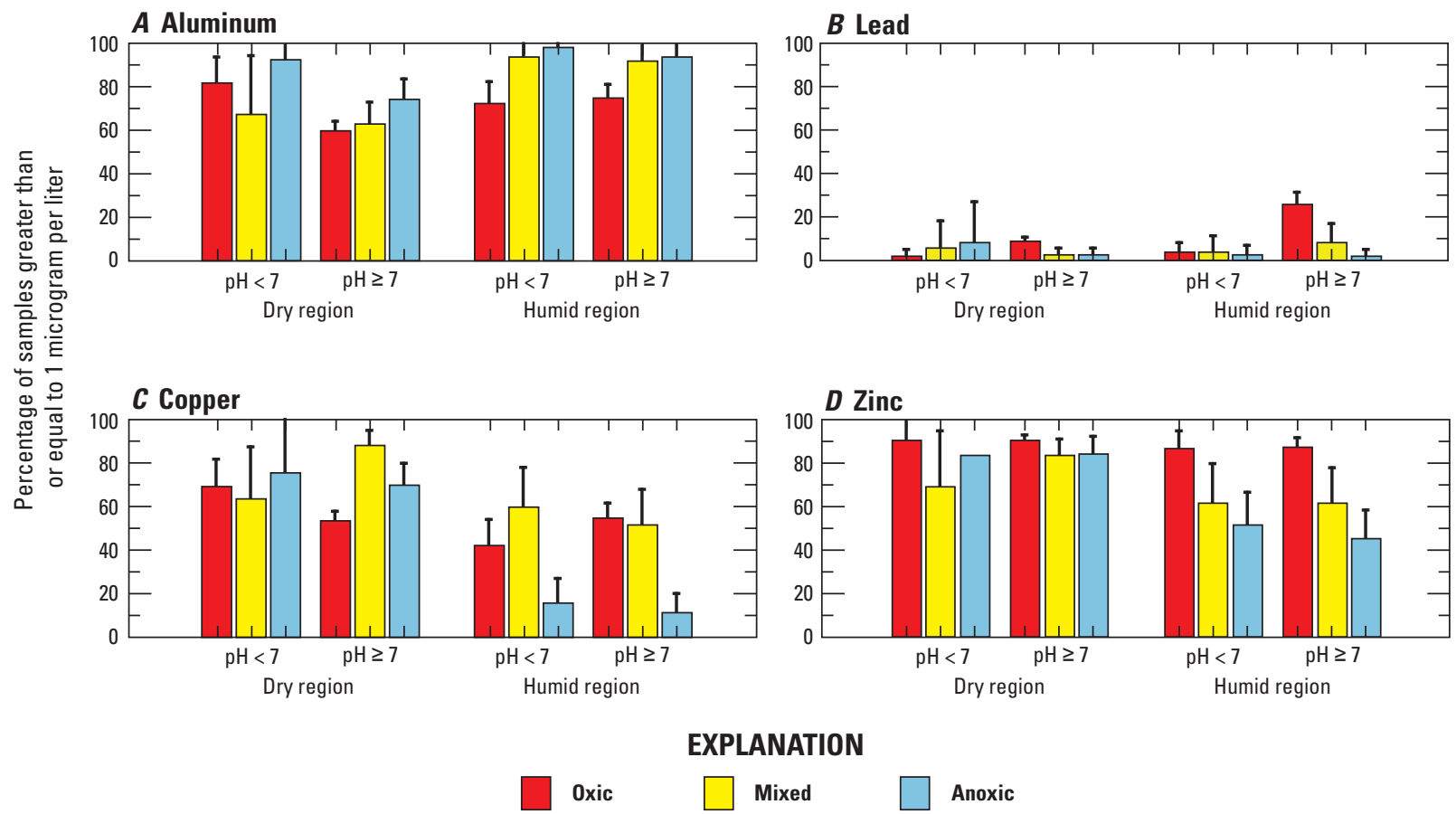

Figure 10. The percentages of groundwater samples with trace-element concentrations greater than or equal to 1 microgram per liter for $(A)$ aluminum, $(B)$ lead, $(C)$ copper, and $(D)$ zinc in dry- and humid-region unconsolidated sand and gravel aquifers. Error bars represent the 95-percent confidence interval of the mean (binomial distribution). $<$, less than; $\geq$, greater than or equal to. 


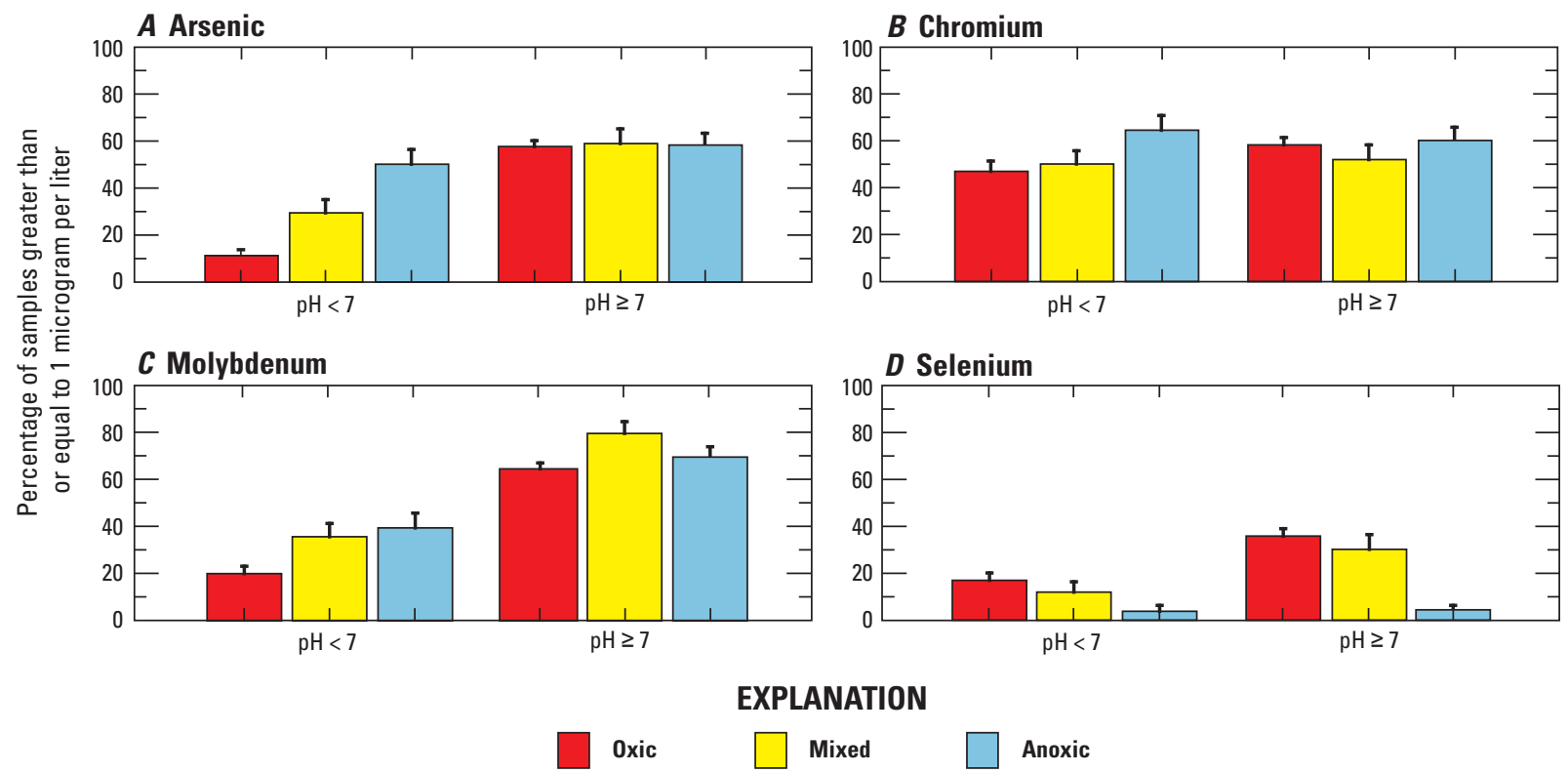

Figure 11. The percentages of samples with trace-element concentrations greater than or equal to 1 microgram per liter for $(A)$ arsenic, $(B)$ chromium, $(C)$ molybdenum, and $(D)$ selenium, by $\mathrm{pH}$ and redox category. Error bars represent the 95 -percent confidence interval of the mean (binomial distribution). $<$, less than; $\geq$, greater than or equal to. 
Glacial unconsolidated sand and gravel aquifers (GLA)
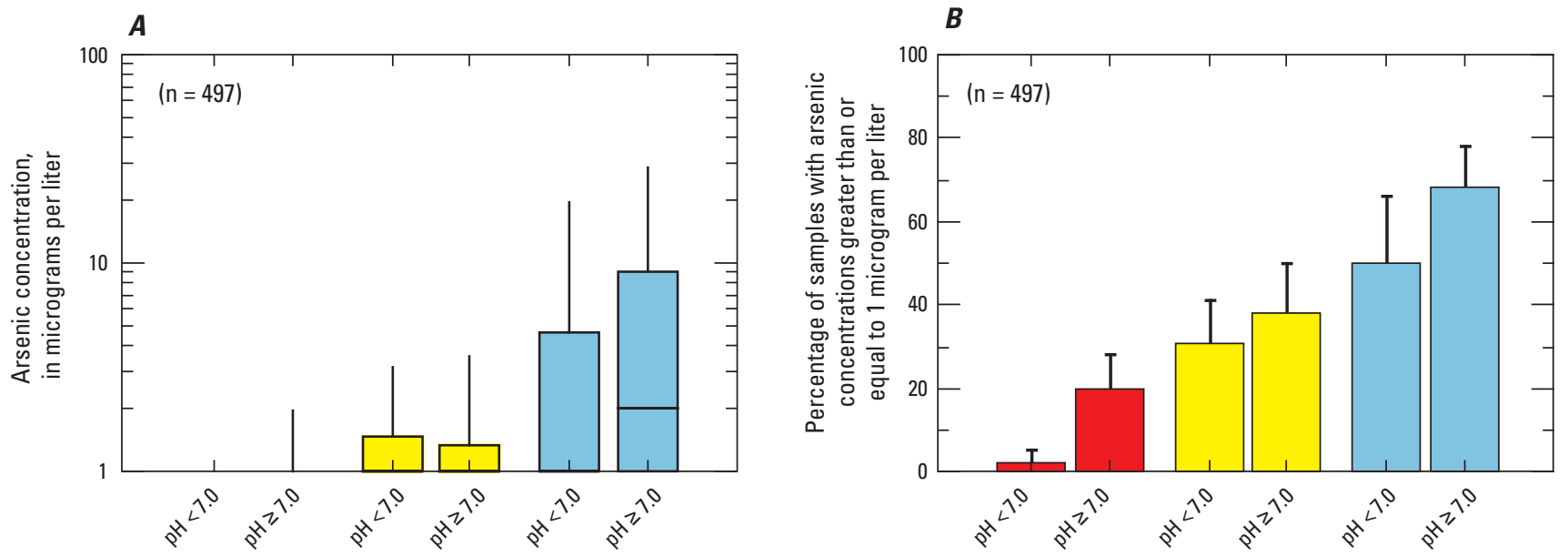

Unconsolidated sand and gravel aquifers (USG)

C

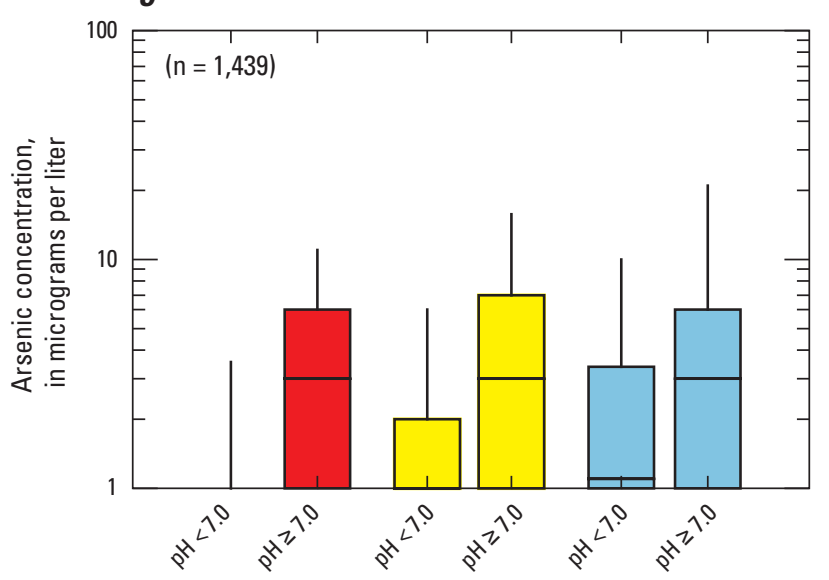

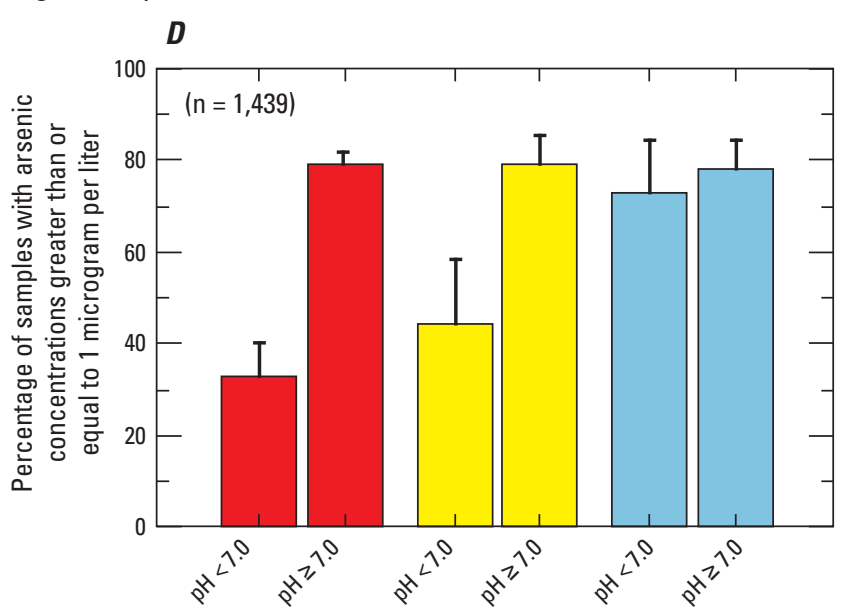

EXPLANATION

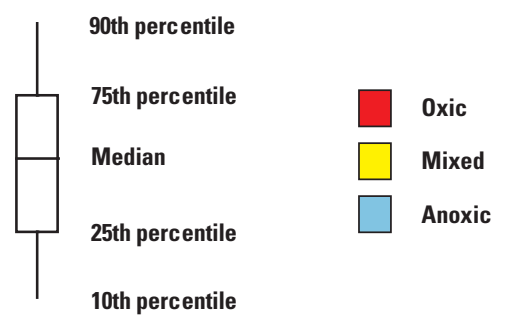

n Number of samples

Figure 12. (A) Concentrations of arsenic in glacial unconsolidated sand and gravel aquifers (GLA), (B) percentages of samples with arsenic concentrations greater than or equal to 1 microgram per liter in GLA aquifers, $(C)$ concentrations of arsenic in unconsolidated sand and gravel aquifers (USG), and (D) percentages of samples with arsenic concentrations greater than or equal to 1 microgram per liter in USG aquifers. Error bars represent the 95-percent confidence intervals of the mean (binomial distribution). 


\section{Relation to Groundwater Age}

The occurrence of trace elements in groundwater is related to the length of time that the water has been in contact with the soil and underlying aquifer materials - that is, the time elapsed since recharge. In this analysis, the presence of tritium above the common reporting level of $2.5 \mathrm{pCi} / \mathrm{L}$ was considered to indicate that at least some young groundwater was present in the sample. Groundwater samples with tritium activities less than or equal to $2.5 \mathrm{pCi} / \mathrm{L}$ are interpreted as containing water predominantly recharged before 1953. In general, old groundwater tends to come from deeper wells with higher $\mathrm{pH}$ and lower DO (figs. 13A-C). These factors are generally associated with deep, long flow paths and long contact time between groundwater and aquifer materials.

Most oxyanion-forming trace elements have greater rates of occurrence in old waters (fig. 14) and can serve as markers of chemical evolution. Fe and Mn also occurred more frequently in older waters, although their occurrence was greater in samples collected from humid-region aquifers. $\mathrm{U}$, which commonly forms soluble complexes under oxic and variable-pH conditions, occurred more frequently in samples collected from older water in the dry-region aquifers, but in humid-region aquifers, $\mathrm{U}$ occurred more often in young water. This may be indicative of processes that favor $\mathrm{U}$ solubility and mobility, such as oxic conditions. In dry regions, ion competition, evaporative concentration, and complexation with bicarbonate and sulfate may be controlling factors (Seiler and others, 2003), whereas in humid regions, deeper, older waters are more often anoxic and may inhibit U mobility. Alternatively, in humid regions, the generally low-pH recharge may more readily dissolve U-bearing minerals in the aquifer matrix.

$\mathrm{Al}$ and $\mathrm{Ni}$ behave as expected for metals soluble at low $\mathrm{pH}$ and under oxic conditions and occurred more frequently in samples of young groundwater, especially in the dry-region aquifers. Based on a small number of samples from the USG aquifer group, B occurrence appeared independent of groundwater age.

\section{Analysis of Multiple Factors Affecting Trace-Element Occurrence}

Potential factors affecting the distribution of selected trace elements, most of which are known to have humanhealth implications, were investigated by using logistic regression. Elements were selected for logistic regression analyses on the basis of the rates of exceedences of HHBs and nonhealth guidelines; in most cases, models were developed for elements that occurred at concentrations greater than benchmarks or guidelines in at least 1 percent of the samples in any given aquifer group (table 10). The elements modeled (as a dependent variable) included Al, As, B, Fe, Mn, Mo, Ni, $\mathrm{Rn}, \mathrm{Se}, \mathrm{Sr}$, and U (table 11). The number of modeled elements differed among aquifer groups because the occurrence of some elements may have been too low to model, as was the case for $\mathrm{B}$ in the SCR, CAR, and CRL aquifer groups. Independent variables used in this analysis included other trace elements, $\mathrm{DO}$, nitrate, ammonia, $\mathrm{Mn}, \mathrm{Fe}$, sulfate, $\mathrm{pH}$, phosphate, majorion chemistry, and well depth.

The analysis was designed to identify factors related to trace-element occurrence and mobility and to identify cooccurrence and nonoccurrence among selected trace elements. Trace-element concentrations were modeled as binary variables because a large proportion of samples for most trace elements had concentrations reported as less than the LRL (or multiple LRLs). This approach allowed the data to be used directly without modification.

In general, the models corroborate the findings comparing trace-element occurrence with redox and $\mathrm{pH}$. For some elements, only the $\mathrm{pH}$ or the redox variable was significant, possibly indicating the dominance of one control over another. Some variation in the number of variables also is likely among aquifer groups because of the number of samples collected from any given aquifer group. Variation in the identified explanatory variables also may be influenced to some degree by which trace elements were measured for any given sample.

Several explanatory variables were either positive or negative covariates with the modeled dependent variables, indicating that these covariates tended to co-occur or not co-occur with the modeled trace element. In some cases, different variables representing similar processes (for example, low DO compared to the presence of $\mathrm{Fe}$ ) were selected for a given model on the basis of model-performance statistics. Because of the effect of climate, separate models were generated for humid-region unconsolidated sand and gravel samples (USGH) and dry-region unconsolidated sand and gravel samples (USGD). The variables associated with occurrence for the selected trace elements are shown by aquifer group in table 11 . The models are summarized by the type of independent variable, and independent variables are arranged by groups (anions and ion complexes, cations, and other); correlations are indicated as positive or negative. More quantitative results for these models by aquifer group are shown in appendix 5. 

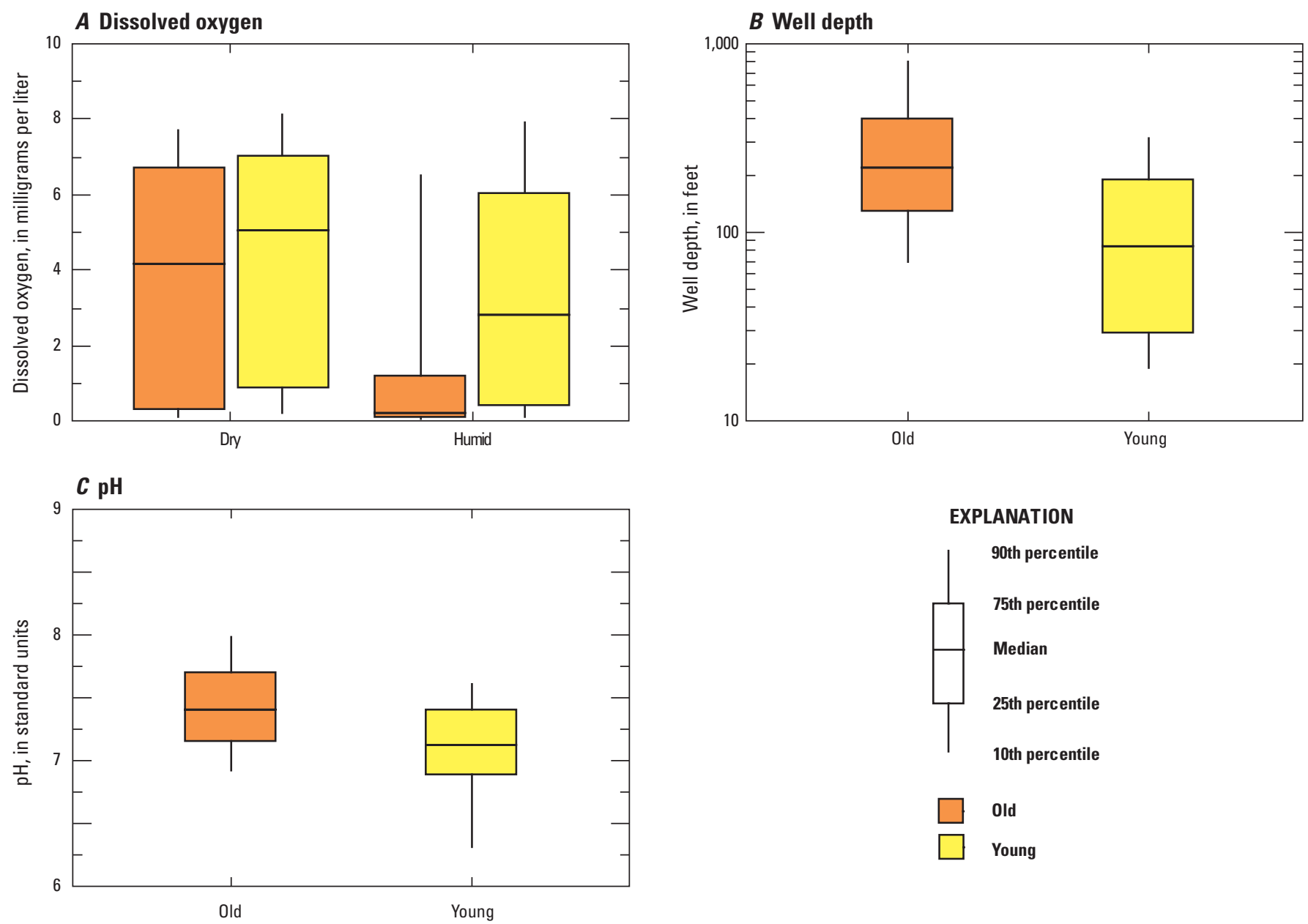

EXPLANATION

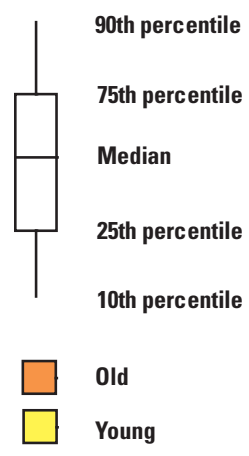

Figure 13. The distribution of $(A)$ dissolved oxygen, $(B)$ well depth, and $(C) \mathrm{pH}$ in groundwater samples by category of age of recharge. "Old" refers to water samples recharged prior to 1953 (tritium activity less than or equal to 2.5 picocuries per liter), and "Young" refers to samples with at least some fraction of water recharged after 1953 (tritium activity greater than 2.5 picocuries per liter). 


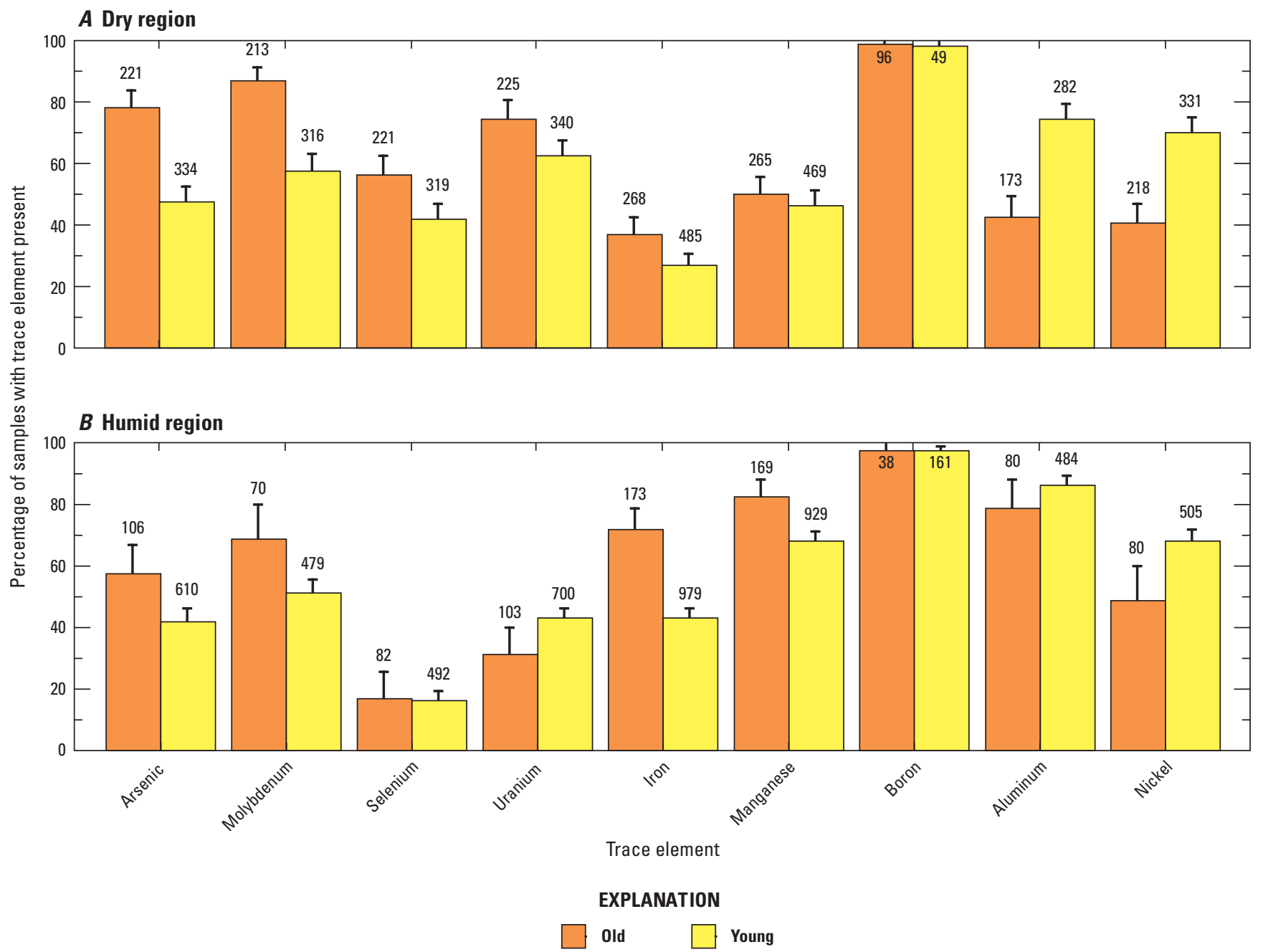

Figure 14. Percentages of groundwater samples with trace-element concentrations greater than or equal to 1 microgram per liter ( $\mu \mathrm{g} / \mathrm{L})$ $(300 \mu \mathrm{g} / \mathrm{L}$ for iron and $50 \mu \mathrm{g} / \mathrm{L}$ for manganese) by category of age of recharge for samples from $(A)$ dry and $(B)$ humid regions. Number above bar is number of samples. "Old" refers to water recharged prior to 1953 (tritium activity less than or equal to 2.5 picocuries per liter), and "Young" refers to water with at least some fraction of water recharged after 1953 (tritium activity greater than 2.5 picocuries per liter). Error bars represent the 95-percent confidence interval of the mean (binomial distribution). 
Table 11. Summary of logistic regression models for selected trace elements in groundwater sampled for the NAWQA Program across the United States by element and major aquifer group, 1992-2003.

[USG, unconsolidated sand and gravel; GLA, glacial unconsolidated sand and gravel; SCS, semiconsolidated sand; SAN, sandstone; SCR, sandstone and carbonate rock; CAR, carbonate rock; BAV, basaltic and volcanic rock; CRL, crystalline rock; B, binary; N, continuous; +, positive covariate; -, negative covariate; yellow shading indicates anions and ion complexes; blue shading indicates cations; green shading indicates other correlates]

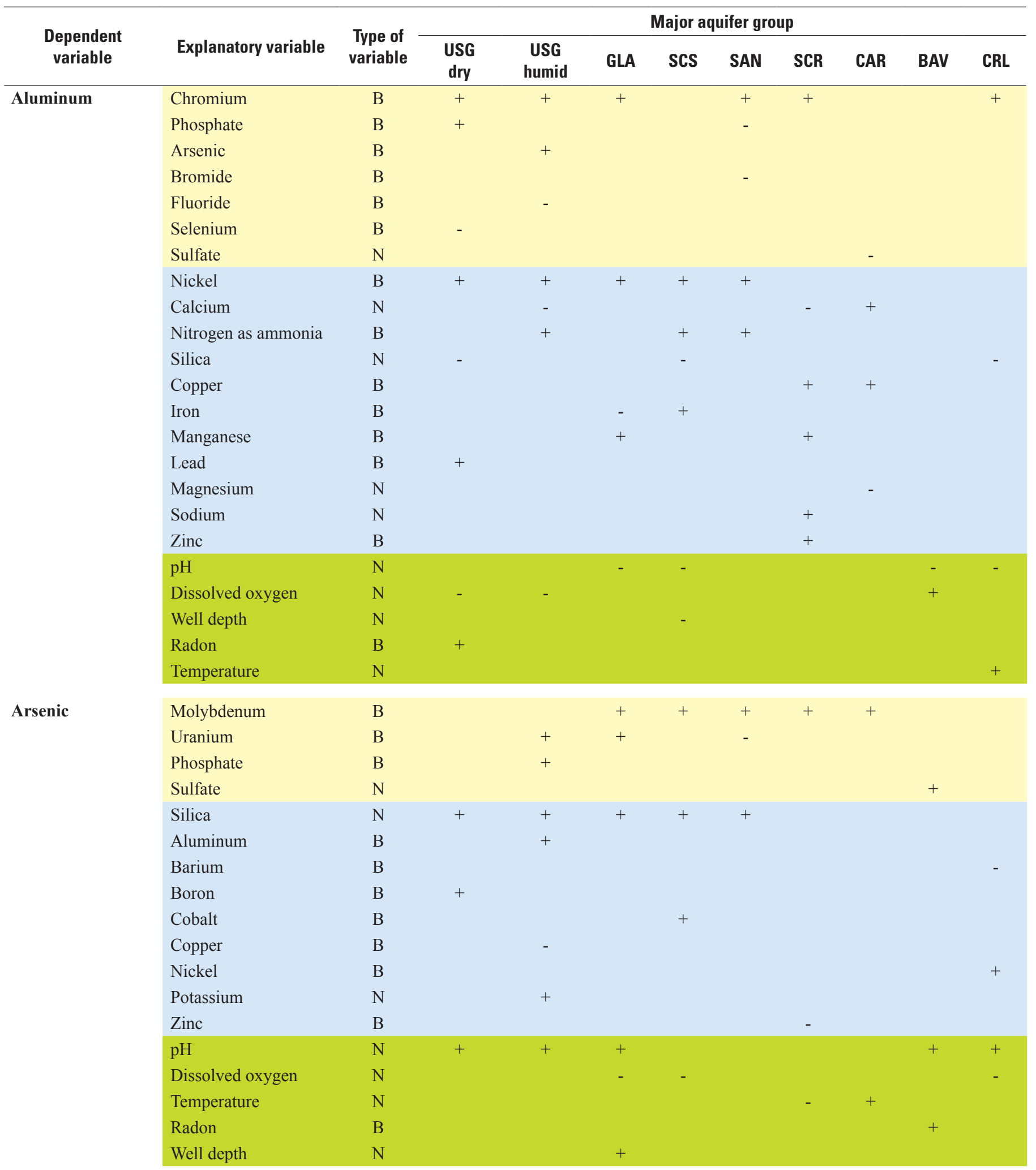


Table 11. Summary of logistic regression models for selected trace elements in groundwater sampled for the NAWQA Program across the United States by element and major aquifer group, 1992-2003.-Continued

[USG, unconsolidated sand and gravel; GLA, glacial unconsolidated sand and gravel; SCS, semiconsolidated sand; SAN, sandstone; SCR, sandstone and carbonate rock; CAR, carbonate rock; BAV, basaltic and volcanic rock; CRL, crystalline rock; B, binary; N, continuous; +, positive covariate; -, negative covariate; yellow shading indicates anions and ion complexes; blue shading indicates cations; green shading indicates other correlates]

\begin{tabular}{|c|c|c|c|c|c|c|c|c|c|c|c|}
\hline \multirow[b]{2}{*}{$\begin{array}{l}\text { Dependent } \\
\text { variable }\end{array}$} & \multirow[b]{2}{*}{ Explanatory variable } & \multirow[b]{2}{*}{$\begin{array}{c}\text { Type of } \\
\text { variable }\end{array}$} & \multicolumn{9}{|c|}{ Major aquifer group } \\
\hline & & & $\begin{array}{l}\text { USG } \\
\text { dry }\end{array}$ & $\begin{array}{c}\text { USG } \\
\text { humid }\end{array}$ & GLA & SCS & SAN & SCR & CAR & BAV & CRL \\
\hline \multirow[t]{16}{*}{ Boron } & Molybdenum & B & & + & + & & & & & & \\
\hline & Arsenic & B & + & & & & & & & & \\
\hline & Bromide & B & & & + & & & & & & \\
\hline & Phosphate & B & & & & & & & & & \\
\hline & Sulfate & $\mathrm{N}$ & & & & & & & & + & \\
\hline & Uranium & B & & & & & & & & & \\
\hline & Aluminum & B & & + & & & & & & & \\
\hline & Magnesium & $\mathrm{N}$ & & & & + & & & & & \\
\hline & Potassium & $\mathrm{N}$ & & & + & & & & & & \\
\hline & Silica & $\mathrm{N}$ & & & & & & & & & \\
\hline & Sodium & $\mathrm{N}$ & & & & & + & & & & \\
\hline & Total dissolved solids & $\mathrm{N}$ & + & + & & & & & & - & \\
\hline & $\mathrm{pH}$ & $\mathrm{N}$ & & & + & + & & & & & \\
\hline & Dissolved oxygen & $\mathrm{N}$ & & & & - & & & & & \\
\hline & Temperature & $\mathrm{N}$ & & & + & & & & & & \\
\hline & Well depth & $\mathrm{N}$ & & & & & & & & & \\
\hline \multirow[t]{15}{*}{ Iron } & Nitrate & B & - & - & & - & & & & & - \\
\hline & Uranium & B & - & & - & - & & & & & - \\
\hline & Arsenic & B & & & & & + & & + & & \\
\hline & Molybdenum & B & & & & & - & & + & & \\
\hline & Chromium & B & & & - & & & & & & \\
\hline & Sulfate & $\mathrm{N}$ & & & & & & + & & & \\
\hline & Copper & B & & 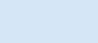 & - & & & - & - & & \\
\hline & Manganese & B & + & . & . & & . & + & & & + \\
\hline & Nitrogen as ammonia & B & & 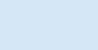 & . & & + & & & & \\
\hline & Sodium & $\mathrm{N}$ & & & & & - & & & & \\
\hline & Dissolved oxygen & $\mathrm{N}$ & - & - & - & - & - & & & - & - \\
\hline & $\mathrm{pH}$ & $\mathrm{N}$ & - & - & - & & - & & & - & \\
\hline & Well depth & $\mathrm{N}$ & + & & + & & & & - & & - \\
\hline & Radon & B & & & - & & & & & & \\
\hline & Total dissolved solids & $\mathrm{N}$ & & & + & & & & & & \\
\hline \multirow[t]{11}{*}{ Manganese } & Chromium & B & & & & - & & - & & & \\
\hline & Nitrate & B & & & - & & - & & & & \\
\hline & Arsenic & B & & & + & & & & & & \\
\hline & Sulfate & $\mathrm{N}$ & & & & & & & + & & \\
\hline & Uranium & B & & & + & & & & & & \\
\hline & Phosphate & B & & & & + & & & & & \\
\hline & Iron & B & & & + & & + & + & + & & + \\
\hline & Copper & B & & - & & & - & & & & \\
\hline & Zinc & B & & & & + & & & & & - \\
\hline & Aluminum & B & & & & & & & & & - \\
\hline & Barium & B & & & & & & & + & & \\
\hline
\end{tabular}


Table 11. Summary of logistic regression models for selected trace elements in groundwater sampled for the NAWOA Program across the United States by element and major aquifer group, 1992-2003._-Continued

[USG, unconsolidated sand and gravel; GLA, glacial unconsolidated sand and gravel; SCS, semiconsolidated sand; SAN, sandstone; SCR, sandstone and carbonate rock; CAR, carbonate rock; BAV, basaltic and volcanic rock; CRL, crystalline rock; B, binary; N, continuous; +, positive covariate; -, negative covariate; yellow shading indicates anions and ion complexes; blue shading indicates cations; green shading indicates other correlates]

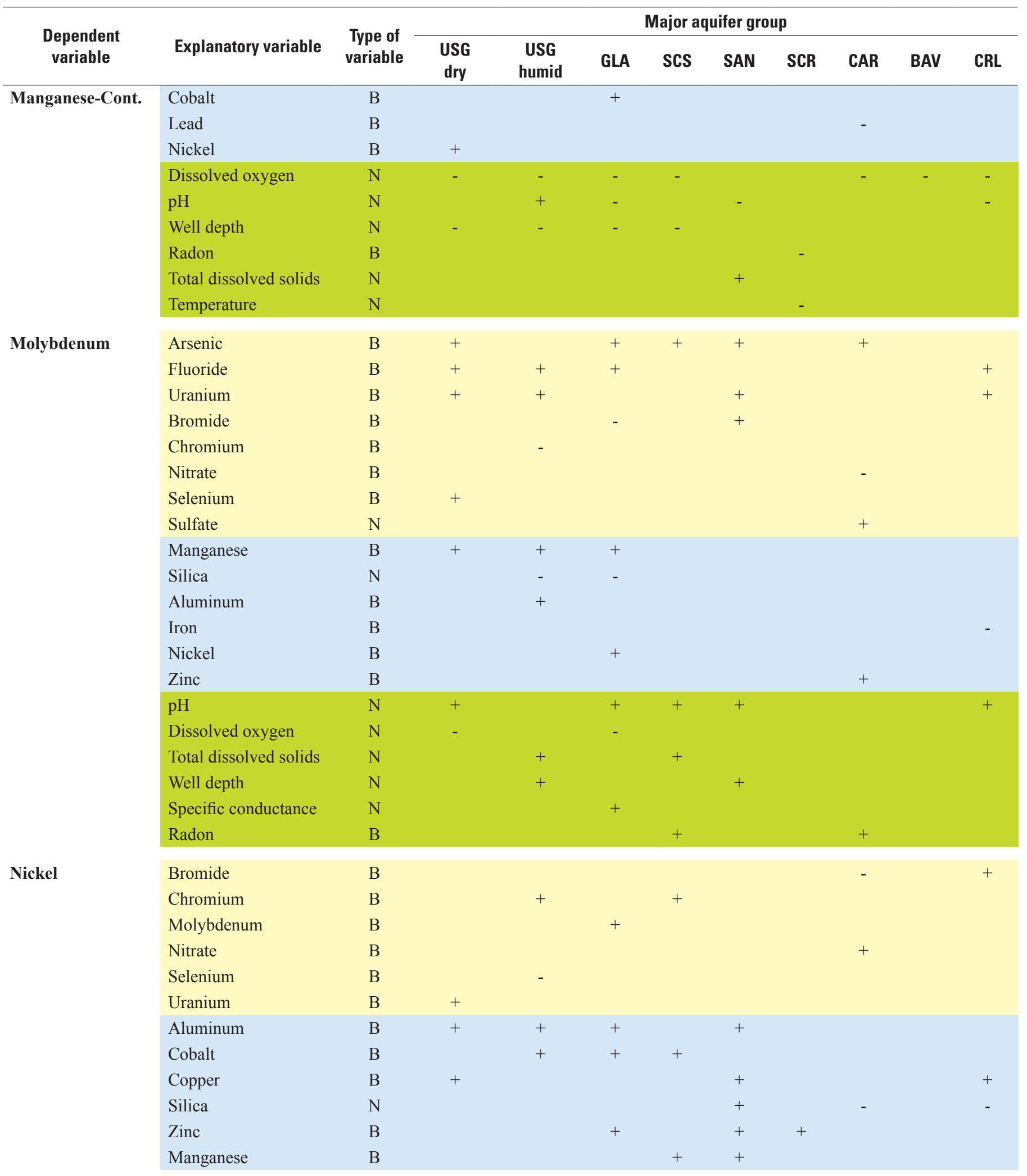


Table 11. Summary of logistic regression models for selected trace elements in groundwater sampled for the NAWQA Program across the United States by element and major aquifer group, 1992-2003.-Continued

[USG, unconsolidated sand and gravel; GLA, glacial unconsolidated sand and gravel; SCS, semiconsolidated sand; SAN, sandstone; SCR, sandstone and carbonate rock; CAR, carbonate rock; BAV, basaltic and volcanic rock; CRL, crystalline rock; B, binary; N, continuous; +, positive covariate; -, negative covariate; yellow shading indicates anions and ion complexes; blue shading indicates cations; green shading indicates other correlates]

\begin{tabular}{|c|c|c|c|c|c|c|c|c|c|c|c|}
\hline \multirow[b]{2}{*}{$\begin{array}{c}\text { Dependent } \\
\text { variable }\end{array}$} & \multirow[b]{2}{*}{ Explanatory variable } & \multirow[b]{2}{*}{$\begin{array}{c}\text { Type of } \\
\text { variable }\end{array}$} & \multicolumn{9}{|c|}{ Major aquifer group } \\
\hline & & & $\begin{array}{l}\text { USG } \\
\text { dry }\end{array}$ & $\begin{array}{l}\text { USG } \\
\text { humid }\end{array}$ & GLA & SCS & SAN & SCR & CAR & BAV & CRL \\
\hline \multirow[t]{11}{*}{ Nickel-Cont. } & Nitrogen as ammonia & B & & - & & & & & - & & \\
\hline & Sodium & $\mathrm{N}$ & & + & & & & - & & & \\
\hline & Calcium & $\mathrm{N}$ & & & & & + & & & & \\
\hline & Iron & B & & & & - & & & & & \\
\hline & Magnesium & $\mathrm{N}$ & & & & & & & & & - \\
\hline & Potassium & $\mathrm{N}$ & & & & & & & & & + \\
\hline & $\mathrm{pH}$ & $\mathrm{N}$ & - & - & & & & - & & & - \\
\hline & Specific conductance & $\mathrm{N}$ & & & & & - & + & + & & \\
\hline & Total dissolved solids & $\mathrm{N}$ & + & & & + & & & & & \\
\hline & Temperature & $\mathrm{N}$ & & + & & & & & & & \\
\hline & Well depth & $\mathrm{N}$ & & & & & + & & & & \\
\hline \multirow[t]{21}{*}{ Radon } & Molybdenum & B & & & - & + & + & & + & & \\
\hline & Nitrate & B & - & & + & + & + & & & & \\
\hline & Sulfate & $\mathrm{N}$ & & & - & & & & - & & - \\
\hline & Arsenic & B & & & - & & & & & & - \\
\hline & Chromium & B & & - & - & & & & & & \\
\hline & Uranium & B & & + & & & & & & & + \\
\hline & Bromide & B & + & & & & & & & & \\
\hline & Fluoride & B & & & + & & & & & & \\
\hline & Phosphate & B & & & & & - & & & & \\
\hline & Selenium & B & & & & & & + & & & \\
\hline & Iron & B & 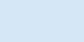 & 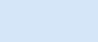 & - & & & + & & & \\
\hline & Cobalt & B & & & + & & & & & & \\
\hline & Lead & B & & & & & & 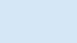 & & & + \\
\hline & Silica & $\mathrm{N}$ & & & & & & - & & & \\
\hline & Manganese & B & & - & & & & & & & \\
\hline & $\mathrm{pH}$ & $\mathrm{N}$ & + & . & - & & & . & - & & \\
\hline & Temperature & $\mathrm{N}$ & & & & & - & - & & & - \\
\hline & Dissolved oxygen & $\mathrm{N}$ & & + & & & & . & & - & \\
\hline & Specific conductance & $\mathrm{N}$ & & & & & & - & & & \\
\hline & Tritium & B & + & & & & & & & & \\
\hline & Well depth & $\mathrm{N}$ & & - & & & & & & & \\
\hline \multirow[t]{9}{*}{ Selenium } & Uranium & B & + & + & + & & + & + & & & \\
\hline & Nitrate & B & + & & + & + & & & & & \\
\hline & Arsenic & B & & & & + & & + & & & \\
\hline & Sulfate & $\mathrm{N}$ & & & & & & & & + & \\
\hline & Bromide & B & + & & & & & & & & \\
\hline & Fluoride & B & + & & & & & & & & \\
\hline & Molybdenum & B & + & & & & & & & & \\
\hline & Iron & B & - & & & - & - & & & & \\
\hline & Manganese & B & - & & - & & & & & & \\
\hline
\end{tabular}


Table 11. Summary of logistic regression models for selected trace elements in groundwater sampled for the NAWOA Program across the United States by element and major aquifer group, 1992-2003._- Continued

[USG, unconsolidated sand and gravel; GLA, glacial unconsolidated sand and gravel; SCS, semiconsolidated sand; SAN, sandstone; SCR, sandstone and carbonate rock; CAR, carbonate rock; BAV, basaltic and volcanic rock; CRL, crystalline rock; B, binary; N, continuous; +, positive covariate; -, negative covariate; yellow shading indicates anions and ion complexes; blue shading indicates cations; green shading indicates other correlates]

\begin{tabular}{|c|c|c|c|c|c|c|c|c|c|c|c|}
\hline \multirow{2}{*}{$\begin{array}{c}\text { Dependent } \\
\text { variable }\end{array}$} & \multirow[b]{2}{*}{ Explanatory variable } & \multirow{2}{*}{$\begin{array}{c}\text { Type of } \\
\text { variable }\end{array}$} & \multicolumn{9}{|c|}{ Major aquifer group } \\
\hline & & & $\begin{array}{l}\text { USG } \\
\text { dry }\end{array}$ & $\begin{array}{c}\text { USG } \\
\text { humid }\end{array}$ & GLA & SCS & SAN & SCR & CAR & BAV & CRL \\
\hline \multirow[t]{7}{*}{ Selenium-Cont. } & Aluminum & $\mathrm{B}$ & - & & & & & & & & \\
\hline & Sodium & $\mathrm{N}$ & & & & & + & & & & \\
\hline & $\mathrm{pH}$ & $\mathrm{N}$ & & & & & & & & - & \\
\hline & Total dissolved solids & $\mathrm{N}$ & & + & & + & & & & & \\
\hline & Well depth & $\mathrm{N}$ & + & + & & & & & & & \\
\hline & Specific conductance & $\mathrm{N}$ & + & & & & & & & & \\
\hline & Dissolved oxygen & $\mathrm{N}$ & & & & & & + & & & \\
\hline \multirow[t]{10}{*}{ Strontium } & Molybdenum & $\mathrm{B}$ & & & & & & & & & + \\
\hline & Sulfate & $\mathrm{N}$ & & & & & & + & & & \\
\hline & Uranium & $\mathrm{B}$ & & & + & & & & & & \\
\hline & Calcium & $\mathrm{N}$ & & & + & & & & & & + \\
\hline & Manganese & $\mathrm{B}$ & & & - & & & & & & \\
\hline & Sodium & $\mathrm{N}$ & & & + & & & & & & \\
\hline & Specific conductance & $\mathrm{N}$ & + & + & & & & & & & \\
\hline & Dissolved oxygen & $\mathrm{N}$ & & & - & & & & - & & \\
\hline & Total dissolved solids & $\mathrm{N}$ & & & & + & + & & & & \\
\hline & $\mathrm{pH}$ & $\mathrm{N}$ & & & & & & & - & & \\
\hline \multirow[t]{23}{*}{ Uranium } & Molybdenum & $\mathrm{B}$ & + & + & & + & + & + & & & + \\
\hline & Selenium & $\mathrm{B}$ & + & & + & & & + & & & \\
\hline & Arsenic & $\mathrm{B}$ & & + & & & & & + & & \\
\hline & Bicarbonate & $\mathrm{N}$ & & & & + & & + & & & \\
\hline & Fluoride & $\mathrm{B}$ & & & + & & & & & & + \\
\hline & Nitrate & $\mathrm{B}$ & & + & & & & & & & - \\
\hline & Phosphate & $\mathrm{B}$ & - & & & & & & - & & \\
\hline & Chromium & $\mathrm{B}$ & + & & & & & & & & \\
\hline & Sulfate & $\mathrm{N}$ & & & & + & & & & & \\
\hline & Nitrogen as ammonia & $\mathrm{B}$ & - & - & & - & - & & & & \\
\hline & Iron & $\mathrm{B}$ & - & - & & & & & & & - \\
\hline & Calcium & $\mathrm{N}$ & & & & & & + & & & + \\
\hline & Copper & $\mathrm{B}$ & + & + & & & & & & & \\
\hline & Nickel & $\mathrm{B}$ & & & + & & & & + & & \\
\hline & Silica & $\mathrm{N}$ & & - & - & & & & & & \\
\hline & Lead & B & & & & & & & & & + \\
\hline & Magnesium & $\mathrm{N}$ & & & + & & + & & & & \\
\hline & Manganese & B & & & + & & & & & & \\
\hline & Potassium & $\mathrm{N}$ & & & & & & & + & & \\
\hline & Total dissolved solids & $\mathrm{N}$ & + & + & & & & & & & \\
\hline & Dissolved oxygen & $\mathrm{N}$ & & & & & & & - & & \\
\hline & $\mathrm{pH}$ & $\mathrm{N}$ & & + & & & & & & & \\
\hline & Well depth & $\mathrm{N}$ & & & - & & & & & & \\
\hline
\end{tabular}




\section{Cationic Elements}

Low $\mathrm{pH}$ was a significant factor in the occurrences of many cationic metals such as $\mathrm{Al}, \mathrm{Fe}, \mathrm{Mn}$, and $\mathrm{Ni}$. In general, these metals, as well as $\mathrm{Cu}, \mathrm{Pb}$, and $\mathrm{Zn}$, adsorb more strongly to aquifer materials as $\mathrm{pH}$ increases (McLean and Bledsoe, 1992; Salbu and Steinnes, 1994). Because of the similarity in behavior, many of these metals co-occurred in the samples used in this study. For example, $\mathrm{Al}$ covaried with $\mathrm{Ni}$ in groundwater from five of nine aquifer groups. Al covariation with $\mathrm{Ni}$ was generally found in aquifer groups with greater proportions of samples having anoxic conditions. Nitrogen as ammonia (an indicator of anoxic conditions) co-occurred with $\mathrm{Al}$ in the USGH, SCS, and SAN aquifer groups, whereas silica was inversely related to Al in the USGD, SCS, and CRL aquifer groups. In general, low $\mathrm{pH}$ was a strong geochemical predictor of groundwater $\mathrm{Al}$ occurrence, affecting the GLA, SCS, BAV, and CRL aquifer-group samples.

These findings are partly corroborated by analysis of the most significant covariates for $\mathrm{Al}$ across all aquifer groups. The percentage of samples with $\mathrm{Al}$ concentrations greater than or equal to $1 \mu \mathrm{g} / \mathrm{L}$ is less than 40 from samples collected from old water and without concentrations of $\mathrm{Ni}$ or $\mathrm{Cr}$ greater than or equal to 20 and $1 \mu \mathrm{g} / \mathrm{L}$, respectively (fig. 15A). This percentage increases with the co-occurrence of $\mathrm{Cr}$ and $\mathrm{Ni}$, but relations also are strengthened by the presence of young water (recharged after 1953) as compared to water that was recharged before 1953 (fig. 15A). Al concentrations in samples from wells in the SCR aquifer group varied with cations such as $\mathrm{Cu}, \mathrm{Mn}, \mathrm{Na}$, and $\mathrm{Zn}$ (table 11). $\mathrm{Al}$ in groundwater samples from the GLA, SCS, and SAN aquifer groups covaried with elements or compounds common in anoxic conditions, such as $\mathrm{Ni}$, nitrogen as ammonia, $\mathrm{Fe}$, and $\mathrm{Mn}$. Concentrations of $\mathrm{Al}$ in groundwater samples from the USGD and USGH aquifer groups, however, correlated directly with low-DO conditions.

Models for Fe occurrence from eight of the nine aquifer groups indicate that it was controlled primarily by low DO in the water samples (table 11) and by low pH (five of the nine groups). Only samples from the CAR aquifer group did not have $\mathrm{DO}, \mathrm{pH}$, or both as variables correlated with $\mathrm{Fe}$. Fe and $\mathrm{Mn}$, although often thought of as co-occurring, exhibit complex behavior that does not necessarily lead to co-occurrence. Models for $\mathrm{Fe}$ (at concentrations greater than or equal to $300 \mu \mathrm{g} / \mathrm{L}$ ) showed co-occurrence with Mn (at concentrations greater than or equal to $50 \mu \mathrm{g} / \mathrm{L}$ ) only in samples collected from the USGD and SCR aquifer groups, and Fe was inversely related to $\mathrm{Mn}$ in the CRL group. By contrast, $\mathrm{Mn}$ varied with $\mathrm{Fe}$ in models for five of the nine aquifer groups (table 11). Overall, Fe occurrence was controlled by both redox (DO) and $\mathrm{pH}$, but redox appeared to control $\mathrm{Mn}$ occurrence more than $\mathrm{pH}$. The models for Fe and $\mathrm{Mn}$ indicate that high Fe predicted the presence of high $\mathrm{Mn}$, but the converse was not as often true. Thus, Mn occurred with Fe, but Fe generally occurred without reduced $\mathrm{Mn}$. This result is consistent with the thermodynamic sequence of redox progression, whereby Mn is reduced first, followed by Fe (Froelich and others, 1979;
McMahon and Chapelle, 2008), and also can be seen in the graph of Mn occurrence (greater than or equal to $50 \mu \mathrm{g} / \mathrm{L}$ ) by categories of $\mathrm{DO}, \mathrm{pH}$, and $\mathrm{Fe}$ (fig. 15B).

The percentage of groundwater samples with Fe greater than or equal to $300 \mu \mathrm{g} / \mathrm{L}$ decreased if $\mathrm{DO}$ was greater than or equal to $1 \mathrm{mg} / \mathrm{L}$, and $\mathrm{pH}$ was greater than or equal to 7 , conditions under which Fe is relatively insoluble (fig. 15C). In addition, samples characterized as young water had less $\mathrm{Fe}$ than samples characterized as old water. Similarly, the percentage of samples with Mn decreased from about 90 to less than 30 as $\mathrm{pH}$ and DO increased (fig. 15B); however, Mn occurrence at concentrations of greater than or equal to $50 \mu \mathrm{g} / \mathrm{L}$ was consistently high (more than 90 percent of samples) and appeared independent of $\mathrm{pH}$ and DO in samples with $300 \mu \mathrm{g} / \mathrm{L}$ or more of Fe (fig. 15B). Low $\mathrm{pH}$ and low DO, as with Fe, are strong indicators of high $\mathrm{Mn}$. Fe also inversely covaried with nitrate, U, or both in the USGD, USGH, GLA, SCS, and CRL aquifer groups. For water samples in the SAN and CAR aquifer groups, Fe covaried with As. Mn covaried with As and $\mathrm{U}$ (GLA) and with Ba (CAR), Co (GLA), Ni (USGD), and Zn (SCS) (table 11).

Ni occurrence covaried with several trace elements, and most often was related to low $\mathrm{pH}$ (USGD, USGH, and SCR, and CRL aquifer groups) or with factors associated with low $\mathrm{pH}$, such as the presence of $\mathrm{Al}, \mathrm{Co}, \mathrm{Cu}$, and $\mathrm{Zn}$ (table 11). The percentage of samples with $\mathrm{Ni}$ was consistently high (greater than 90 percent) when Co was present (fig. 15D).

\section{Oxyanion- and Ion-Complex-Forming Elements}

Models for oxyanion- and ion-complex-forming elements also were influenced by $\mathrm{pH}$ and redox variables. Unlike the cationic metals, however, increases in $\mathrm{pH}$ generally result in increased desorption of oxyanion-forming elements from aquifer materials, thus increasing the solubility of those metals. In particular, As and Mo occurred most often in high-pH conditions (five of nine aquifer groups in table 11).

Arsenic occurrence covaried with silica (USGD, USGH, GLA, SAN, and SCS aquifer groups), Mo (GLA, SCS, SAN, $\mathrm{SCR}$, and CAR aquifer groups), and high $\mathrm{pH}$ (USGD, USGH, GLA, BAV, and CRL aquifer groups) (table 11). The percentage of samples with As concentrations greater than or equal to $1 \mu \mathrm{g} / \mathrm{L}$ and with low Mo and silica concentrations was about 12. This percentage increased to 40 to 45 percent if either Mo or silica were present and increased to about 85 percent if both Mo and silica were present (fig. 16A). The effect of $\mathrm{pH}$ on these relations is likely related to increased solubility through desorption, whereby the occurrence of As, associated with Mo or silica, was greater for high-pH samples than for low-pH samples. Arsenic co-occurred with $U$ and phosphate in the USGH and GLA aquifer groups. Thus, competitive sorption also may play a role in the occurrence of As. Low DO correlated with As in the GLA, SCS, and CRL aquifer groups, indicating that in addition to the process of $\mathrm{pH}$-driven desorption, redox may be an important control in some aquifer groups and (or) climates. 


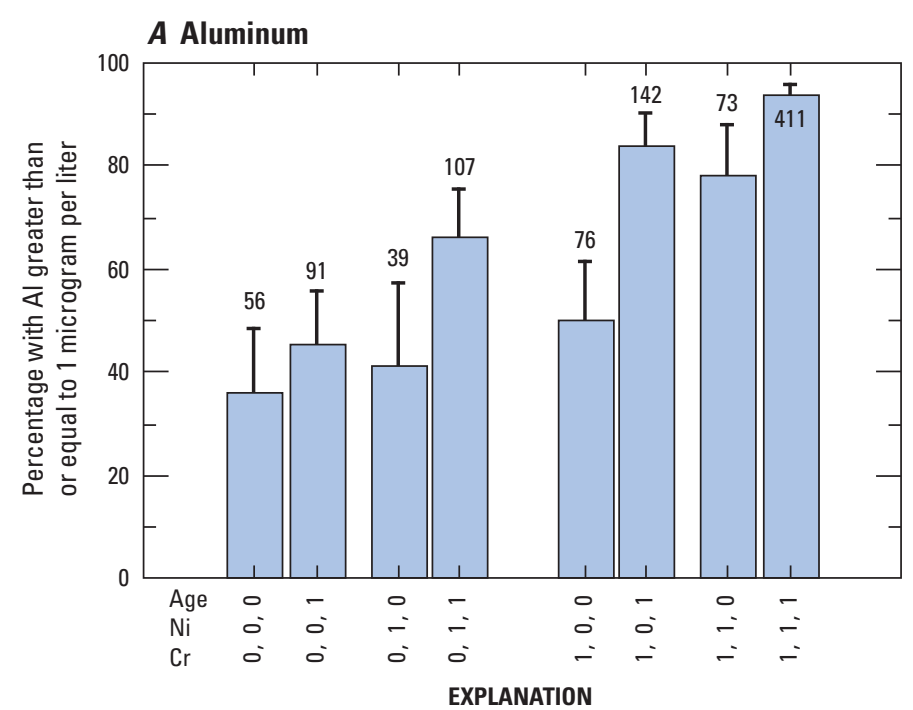

Covariates:

Age (old or young)

$\mathrm{Cr} \geq 1$ microgram per liter

$\mathrm{Ni} \geq 20$ micrograms per liter

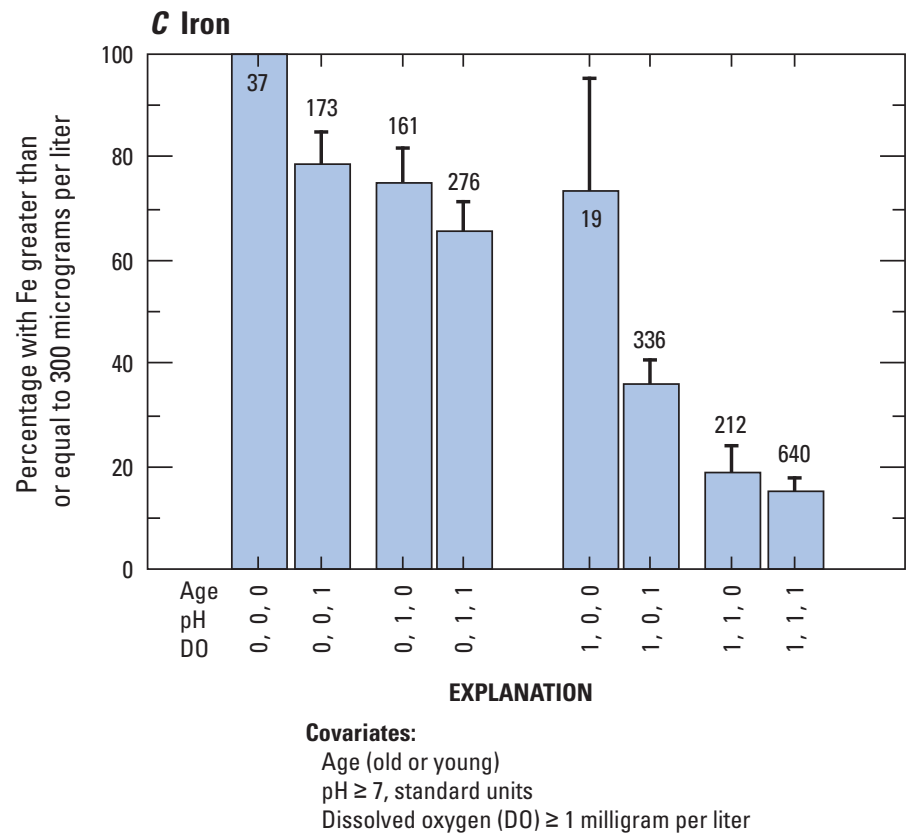

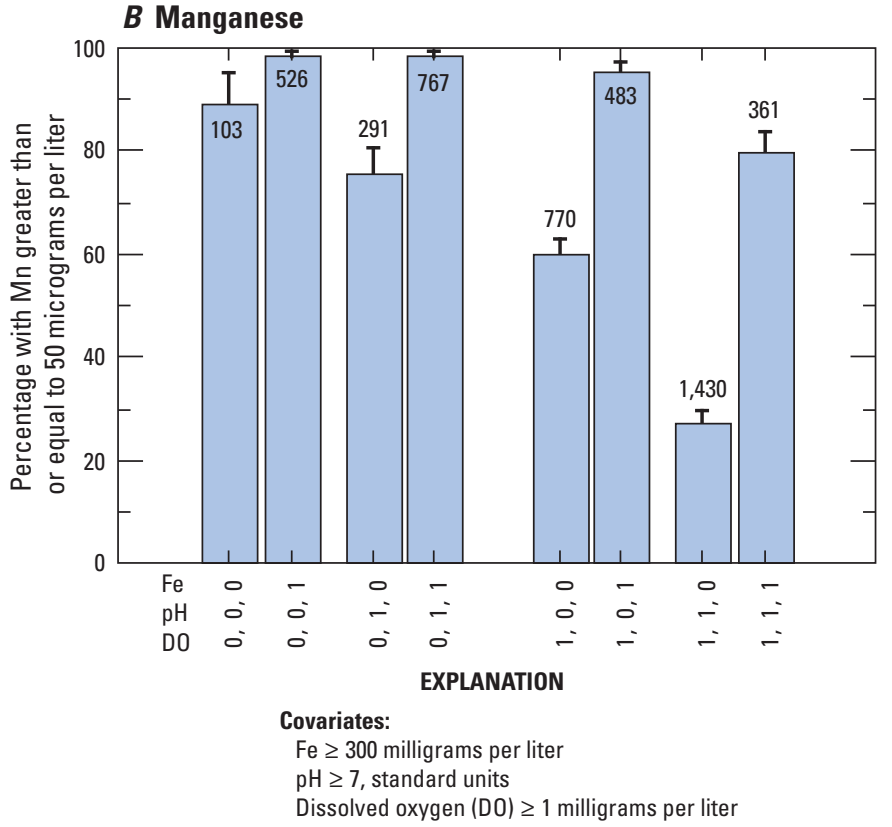

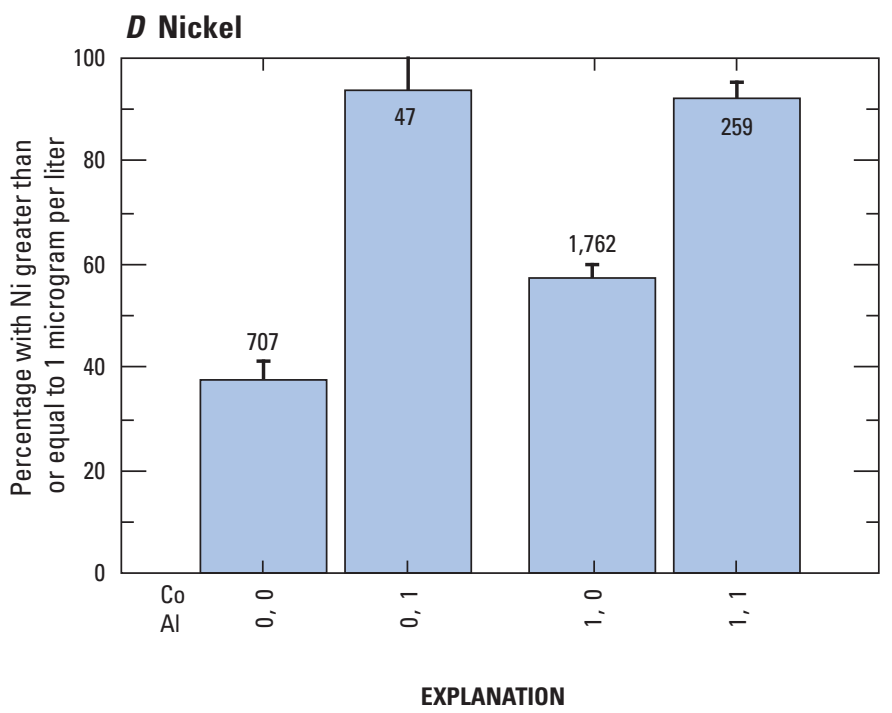

Covariates:

Co $\geq 1$ microgram per liter $\mathrm{Al} \geq 1$ microgram per liter

Figure 15. The percentages of groundwater samples with concentrations greater than reporting level for $(A)$ aluminum (Al), $(B)$ manganese $(\mathrm{Mn}),(C)$ iron $(\mathrm{Fe})$, and $(D)$ nickel ( $\mathrm{Ni})$, by major covariates from logistic regression models. Zero (O) indicates nonoccurrence of a covariate, and one (1) indicates occurrence except for age, for which zero is old (pre-1953), and one is young (post-1953) water. Number above bar is number of samples. Reporting level is 1 microgram per liter $(\mu \mathrm{g} / \mathrm{L})$ for aluminum and nickel; $300 \mu \mathrm{g} / \mathrm{L}$ for iron; and $50 \mu \mathrm{g} / \mathrm{L}$ for manganese. Error bars represent 95-percent confidence interval of the mean (binomial distribution). $\geq$, greater than or equal to; $\mathrm{Cr}$, chromium; Co, cobalt. 


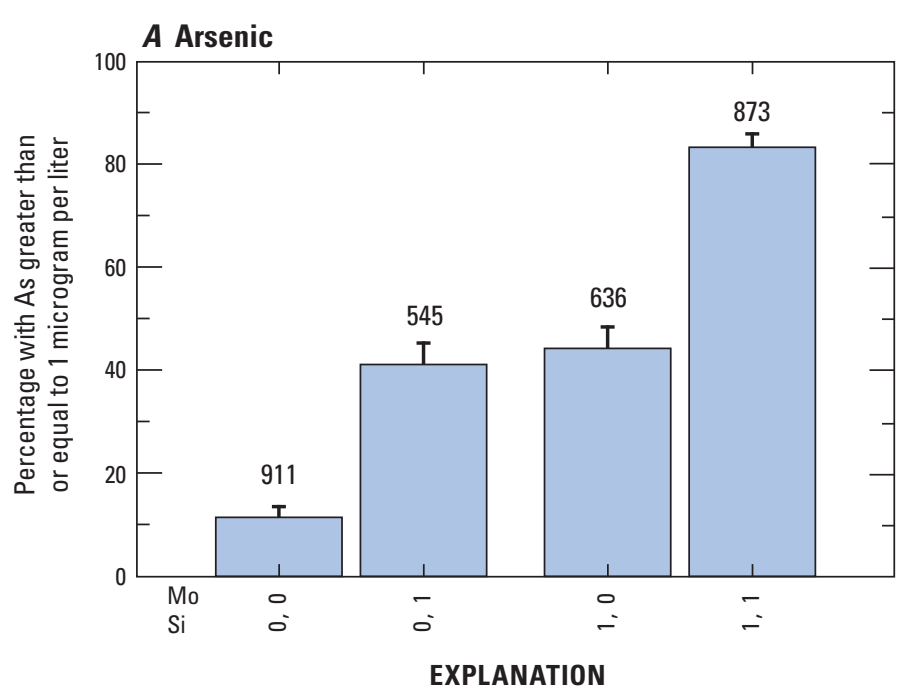

Covariates:

Mo $\geq 1$ microgram per liter

$\mathrm{Si} \geq 20$ milligrams per liter

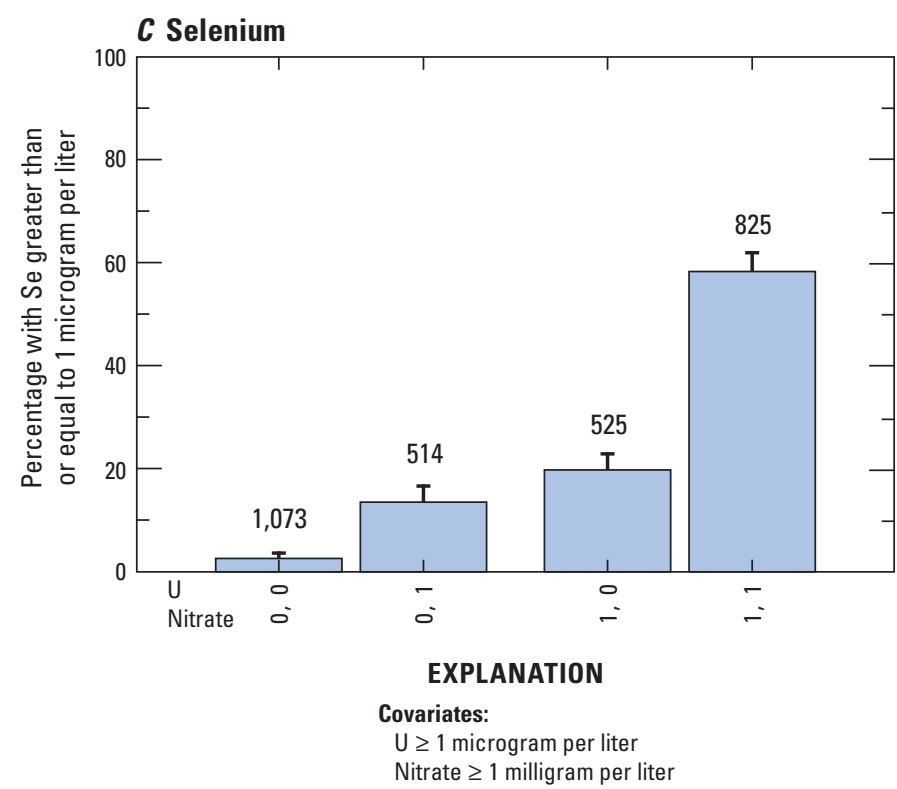

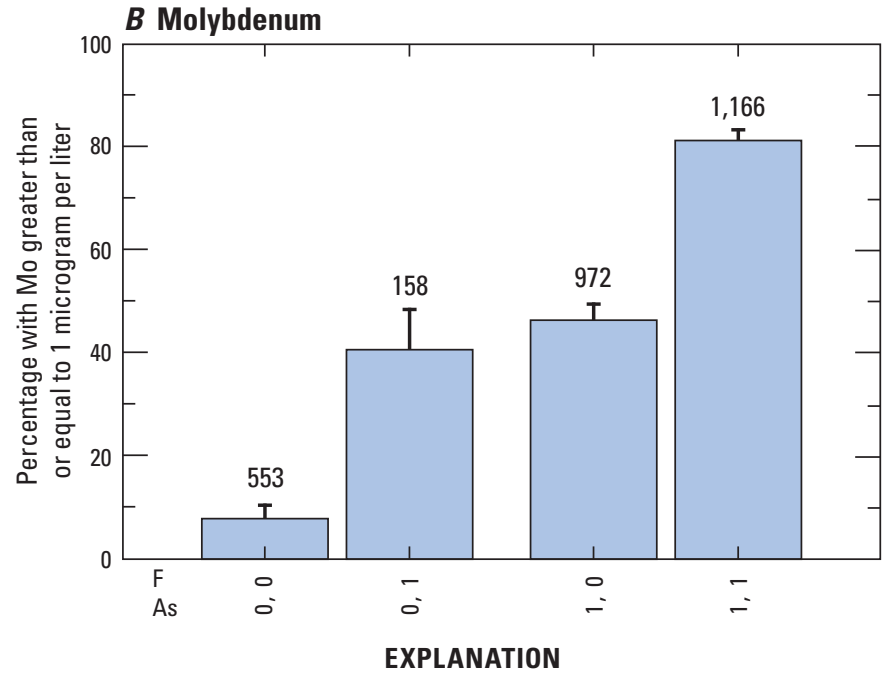

Covariates:

$\mathrm{F} \geq 0.1$ milligram per liter As $\geq 1$ microgram per liter

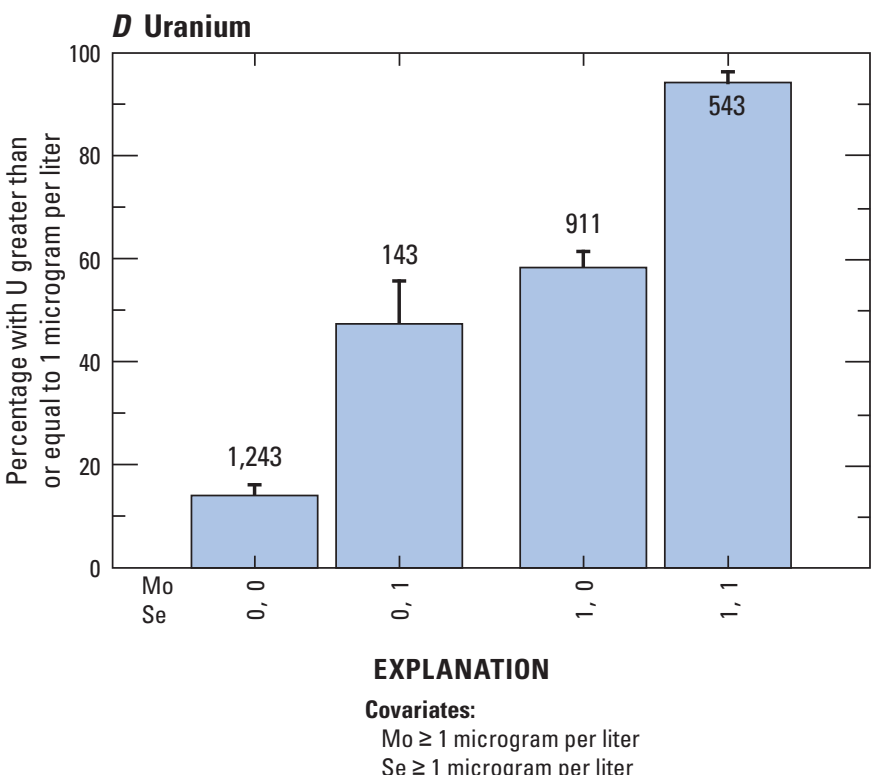

Figure 16. The percentages of groundwater samples with concentrations greater than or equal to 1 microgram per liter for $(A)$ arsenic $(A s),(B)$ molybdenum (Mo), $(C)$ selenium $(\mathrm{Se})$, and $(D)$ uranium (U), by major covariates from logistic regression models. Zero (0) indicates nonoccurrence of a covariate, and one (1) indicates occurrence. Number above bar is number of samples. Error bars represent the 95-percent confidence interval of the mean (binomial distribution); $\geq$ greater than or equal to; Si, silicon; $F$, flouride. 
Mo in groundwater co-occurred with several trace elements, such as As, fluoride, Mn, and U. In groundwater from the CRL aquifer group, Mo co-occurred with fluoride, U, and high $\mathrm{pH}$ (table 11). These relations may be indicative of granitic lithologies, which are often enriched in these elements and can produce high $\mathrm{pH}$ in groundwater (Edmunds and Smedley, 2005). Mo was inversely related to Fe in the CRL aquifer group (table 11). In general, high $\mathrm{pH}$ and in some cases low DO or increasing well depth, appeared to provide a strong control for Mo. In samples with less than $0.1 \mathrm{mg} / \mathrm{L}$ of fluoride and less than $1 \mu \mathrm{g} / \mathrm{L}$ of As, the percentage with Mo greater than or equal to $1 \mu \mathrm{g} / \mathrm{L}$ was less than 10 (fig. 16B). This percentage increased to 40 to 50 percent if either fluoride or As was present and increased to more than 80 percent if both were present (fig. 16B). The effect of $\mathrm{pH}$ on these relations was similar to the effect on As in that the percentage of samples associated with As or silica was greater for high-pH samples than for low $\mathrm{pH}$ samples.

Se covaried with combinations of $\mathrm{U}, \mathrm{As}$, and nitrate (in the GLA, SAN, SCR, SCS, USGH, and USGD aquifer groups) (table 11). The percentages of samples with concentrations of Se greater than or equal to $1 \mu \mathrm{g} / \mathrm{L}$ increased with the occurrence of either nitrate or $U$ (to about 13 and 20 percent, respectively) and to nearly 60 percent when both were present (fig. 16C). In the USGD aquifer group, Se covaried with bromide, fluoride, and sulfate in addition to $U$ and nitrate. In four of nine aquifer groups, Se covaried inversely with Fe and (or) $\mathrm{Mn}$. Se in groundwater from some aquifer groups also appears to be related to TDS and conductance (table 11).

$\mathrm{U}$ was present in about half of all groundwater samples in which it was measured and covaried with more than one ion in most aquifer groups. U covaried with Mo in the USGD, USGH, SCS, SAN, SCR, and CRL aquifer groups (table 11). Se (in the USGD, GLA, SCR, aquifer groups) and As (in the USGH and CAR aquifer groups) also covaried with U, as did complexing ions such as bicarbonate (in the SCS and SCR aquifer groups) and sulfate (in the SCS aquifer group). Fluoride in groundwater samples from the GLA and CRL aquifer groups covaried with $\mathrm{U}$, possibly indicating sources in granitic rocks. The presence of nitrogen as ammonia and $\mathrm{Fe}$ in samples, however, was always inversely related to $\mathrm{U}$, possibly indicating sufficiently anoxic conditions to immobilize U. Mo and Se were the most common covarying trace elements in samples from this study and were strongly related to the overall presence of $U$ in the samples. The percentages of samples with $U$ at concentrations greater than or equal to $1 \mu \mathrm{g} / \mathrm{L}$ increased with the co-occurrence of Se (to nearly 60 percent) or Mo (to nearly 50 percent); however, the percentages of samples with $U$ increased to about 95 if both $\mathrm{Se}$ and Mo were present (fig. 16D).

The occurrence of trace elements such as As, Mo, Se, and $\mathrm{U}$ have been examined in detail in studies of unconsolidated aquifers (Deverel and Millard, 1988; Dubrovsky and others, 1991; Fujii and Swain, 1995; Welch and Lico, 1998; Seiler and others, 2003). In general, these studies found that lithologic sources, redox chemistry, and evaporative concentration were significant processes affecting occurrence. In particular, some Upper Cretaceous marine sedimentary rocks in the western United States appeared to be enriched in Se, U, and other elements (Seiler and others, 2003).

\section{Other Elements}

$\mathrm{Rn}$ covaried with some elements that are generally mobile under oxic conditions, including U (in the USGH and CRL aquifer groups), bromide (in the USGD aquifer group), fluoride (in the GLA aquifer group), and Se (in the SCR aquifer group). It also co-occurred with Mo in three aquifer groups. However, in the GLA group, Rn was inversely related to most covariates. Rn was generally related to factors indicative of recently recharged groundwater or groundwater from highly transmissive aquifers. These factors include low $\mathrm{pH}$ (as in the GLA and CAR aquifer groups), low water temperature (shallow water table), low specific conductance (short residence time), and shallow well depths.

Boron exists predominantly as an uncharged ion in groundwater (Hem, 1985). In this study, B frequently occurred in samples from the major aquifer groups, but exceedences of HHBs were less common (table 11). B covaried with relatively few other elements, and the covariates differed according to aquifer group.

\section{Co-occurrence of Trace Elements at Concentrations Greater than Human- Health Benchmarks}

Logistic regression analysis showed that several trace elements commonly occur together, and that some combinations of some trace elements are good predictors of the occurrence of other trace elements exceeding HHBs. Further analysis of the co-occurrence of trace elements that exceeded HHBs was done to identify samples with more than one trace-element exceedence of HHBs. In this way, it was possible to relate high concentrations of trace elements in water samples to potentially controlling factors and to identify which elements commonly co-occur. For example, in a study of domestic wells and multiple HHB exceedences, high TDS was shown to be related to the number of contaminants present in any given sample (DeSimone, 2009).

Recently, interest has increased in assessing contaminant mixtures as they relate to human health, partly to infer mechanisms of contamination and processes that control mobility. Characterizing all possible mixtures in a water sample is a difficult task; assessing the toxicity of any of these possible mixtures is even more challenging (Ryker and Small, 2008). Thus, for this analysis, which focused on trace elements, data on only selected trace elements were used in characterizing sample mixtures. 
For this analysis, 2,714 groundwater samples with data on a specific set of trace elements- $\mathrm{Sb}, \mathrm{As}, \mathrm{Ba}, \mathrm{Be}, \mathrm{Cd}, \mathrm{Cr}$, $\mathrm{Cu}, \mathrm{Pb}, \mathrm{Mn}, \mathrm{Mo}, \mathrm{Ni}, \mathrm{Se}, \mathrm{Ag}, \mathrm{U}$, and $\mathrm{Zn}$ - were used. Radon was not included in the analysis because it occurs at concentrations exceeding the USEPA-proposed MCL of $300 \mathrm{pCi} / \mathrm{L}$ in 65 percent of samples (table 4) and would therefore co-occur with other contaminants in the majority of samples. B, Co, $\mathrm{Sr}$, and $\mathrm{Tl}$ were not included because concentrations were measurable in too few samples or because of the absence of regulation by the USEPA. In this subset of data, the rate of HHB exceedence by at least one or more trace elements was 21.1 percent (572 of the 2,714 samples with at least one HHB exceedence). Of those, 62 samples (2.3 percent overall) had two or more trace elements that exceeded HHBs (table 12).

Most of the multiple exceedences of HHBs occurred in the USG aquifer group. Of the 62 samples with multiple HHB exceedences, 50 were from the USG. The overall percentage of multiple HHB exceedences in the USG-aquifer samples was 4.2 percent $(50$ of 1,187). Of the remaining 12 samples with multiple HHB exceedences, 6 were from the GLA, and 3 were from the CRL (table 12).

The multiple HHB exceedences in samples from the USG aquifer group were dominated by co-occurrences of two of the following three elements: As, Mn, and U (table 13). Forty-two percent of the HHB exceedences consisted of the co-occurrence of As and Mn, 18 percent consisted of $U$ and
$\mathrm{Mn}$, and 8 percent consisted of As and U. Mo was included in 22 percent of the mixtures overall.

Multiple HHB exceedences in groundwater from the USG (42 of the 50) occurred in four areas: the northern High Plains, the Nevada Basin and Range, the California Central Valley, and the Santa Ana Basin. The sampled wells in these areas were predominantly in urban (17), agricultural (14), and mixed (11) land-use areas. Water samples from 21 of the same wells were classified as being mixed with respect to redox conditions: 13 were anoxic, and 6 were oxic, and 2 were not classified. Most of the elements that co-occur at concentrations greater than HHBs are redox sensitive and are more mobile under anoxic or mixed conditions; these conditions were more common in drinking-water wells and in shallow monitoring wells in urban areas than in wells in agricultural settings.

$\mathrm{Sr}$ and $\mathrm{B}$ were measured along with the broader suite described above in a subset of 819 samples, primarily in water samples from the USG aquifer group. Concentrations of B and $\mathrm{Sr}$ at concentrations greater than HHBs in the High Plains aquifer commonly occur in various combinations with $\mathrm{As}, \mathrm{Mn}$, Mo, and U (table 14). In the USG aquifer-group samples from the Santa Ana Basin and the Coastal Range Province of southern California, As, B, Mn, Mo, and U frequently cooccur. Sr concentrations that exceed HHBs also are found with high concentrations of As and Mo in the GLA aquifer group (table 14), primarily in western Ohio and eastern Indiana.

Table 12. Number of groundwater samples collected for the NAWQA Program across the United States and number of multiple human-health benchmark exceedences by aquifer group, 1992-2003.

[HHB, human-health benchmark; BAV, basaltic and volcanic rock; CAR, carbonate rock; GLA, glacial unconsolidated sand and gravel; CRL, crystalline rock; SAN, sandstone; SCR, sandstone and carbonate rock; SCS, semiconsolidated sand; USG, unconsolidated sand and gravel]

\begin{tabular}{cccccccc}
\hline Aquifer group & $\begin{array}{c}\text { Total number } \\
\text { of samples }\end{array}$ & \multicolumn{2}{c}{$\begin{array}{c}\text { Samples with one or more } \\
\text { HHB exceedences }\end{array}$} & & \multicolumn{2}{c}{$\begin{array}{c}\text { Samples with two or more } \\
\text { HHB exceedences }\end{array}$} \\
& & Number & Percentage & & Number & Percentage \\
\hline BAV & 30 & 0 & 0.0 & & 0 & 0.0 \\
CAR & 161 & 4 & 2.5 & & 0 & 0.0 \\
GLA & 464 & 101 & 21.8 & & 6 & 1.3 \\
CRL & 188 & 26 & 13.8 & & 3 & 1.6 \\
SAN & 214 & 49 & 22.9 & & 2 & 0.9 \\
SCR & 173 & 3 & 1.7 & & 0 & 0.0 \\
SCS & 297 & 45 & 15.2 & & 1 & 0.3 \\
USG & 1,187 & 344 & 29.0 & & 50 & 4.2 \\
\multicolumn{1}{c}{ Total } & 2,714 & 572 & 21.1 & & 62 & 2.3 \\
\hline
\end{tabular}


Table 13. Co-occurrence of trace elements at concentrations greater than human-health benchmarks in samples collected for the NAWQA Program across the United States from the unconsolidated sand and gravel aquifer group, $1992-2003$.

[Total number of samples was 1,187; USG, unconsolidated sand and gravel; Mn, manganese; As, arsenic; U, uranium; Mo, molybdenum; Cd, cadmium; Se, selenium]

\begin{tabular}{|c|c|c|c|c|c|c|c|c|}
\hline \multirow{2}{*}{$\begin{array}{c}\text { Number of trace } \\
\text { elements exceeding } \\
\text { human-health } \\
\text { benchmarks }\end{array}$} & \multirow{2}{*}{$\begin{array}{c}\begin{array}{c}\text { Number of samples } \\
\text { with multiple } \\
\text { exceedences } \\
(\mathbf{N}=\mathbf{5 0})\end{array} \\
2\end{array}$} & \multirow{2}{*}{$\begin{array}{c}\begin{array}{c}\text { Percentage } \\
\text { of multiple }\end{array} \\
\text { exceedences }\end{array}$} & \multicolumn{6}{|c|}{$\begin{array}{l}\text { Co-occurrence of trace elements in groundwater at concentrations } \\
\text { above a human-health benchmark in the USG aquifer group }\end{array}$} \\
\hline & & & $\mathrm{Mn}$ & As & $\mathrm{U}$ & Mo & & \\
\hline \multirow[t]{3}{*}{3} & 2 & 4 & $\mathrm{Mn}$ & As & $\mathrm{U}$ & & & \\
\hline & 1 & 2 & & As & $\mathrm{U}$ & Mo & & \\
\hline & 1 & 2 & $\mathrm{Mn}$ & & $\mathrm{U}$ & Mo & & \\
\hline \multirow[t]{8}{*}{2} & 21 & 42 & $\mathrm{Mn}$ & As & & & & \\
\hline & 9 & 18 & $\mathrm{Mn}$ & & $\mathrm{U}$ & & & \\
\hline & 4 & 8 & & As & $\mathrm{U}$ & & & \\
\hline & 4 & 8 & & As & & Mo & & \\
\hline & 3 & 6 & & & $\mathrm{U}$ & Mo & & \\
\hline & 1 & 2 & $\mathrm{Mn}$ & & & & & $\mathrm{Cd}$ \\
\hline & 1 & 2 & & As & & & $\mathrm{Se}$ & \\
\hline & 1 & 2 & & & $\mathrm{U}$ & & $\mathrm{Se}$ & \\
\hline \multicolumn{2}{|c|}{ Total exceedences by element } & & 36 & 35 & 23 & 11 & 2 & 1 \\
\hline
\end{tabular}

Table 14. Co-occurrence of trace elements with boron and strontium at concentrations greater than human-health benchmarks in groundwater samples collected for the NAWQA Program across the United States, 1992-2003.

[Total number of samples $=819$; USG, unconsolidated sand and gravel; GLA, glacial unconsolidated sand and gravel; As, arsenic; B, boron; Mo, molybdenum; U, uranium; Mn, manganese; Sr, strontium]

\begin{tabular}{|c|c|c|c|c|c|c|c|c|}
\hline \multirow{2}{*}{$\begin{array}{c}\text { Number of trace } \\
\text { elements exceeding } \\
\text { human-health } \\
\text { benchmarks }\end{array}$} & \multirow{2}{*}{$\begin{array}{c}\begin{array}{c}\text { Aquifer } \\
\text { group }\end{array} \\
\text { USG }\end{array}$} & \multirow{2}{*}{$\begin{array}{c}\begin{array}{c}\text { Number of samples } \\
\text { with multiple } \\
\text { exceedences } \\
(\mathbf{N}=14)\end{array} \\
1\end{array}$} & \multicolumn{6}{|c|}{$\begin{array}{l}\text { Co-occurrence of trace elements at concentrations above a human- } \\
\text { health benchmarks in the USG and GLA aquifer groups }\end{array}$} \\
\hline & & & As & $\mathrm{B}$ & & Mo & & $\mathrm{U}$ \\
\hline \multirow[t]{3}{*}{3} & USG & 1 & As & & $\mathrm{Mn}$ & & $\mathrm{Sr}$ & \\
\hline & USG & 1 & & $\mathrm{~B}$ & & Mo & & $\mathrm{U}$ \\
\hline & USG & 1 & & & & Mo & $\mathrm{Sr}$ & $\mathrm{U}$ \\
\hline \multirow[t]{6}{*}{2} & USG & 1 & & & $\mathrm{Mn}$ & & $\mathrm{Sr}$ & \\
\hline & USG & 1 & As & $\mathrm{B}$ & & & & \\
\hline & GLA/USG & 5 & As & & & & $\mathrm{Sr}$ & \\
\hline & GLA & 1 & & & & Mo & $\mathrm{Sr}$ & \\
\hline & USG & 1 & & $\mathrm{~B}$ & $\mathrm{Mn}$ & & & \\
\hline & USG & 1 & & & & & $\mathrm{Sr}$ & $\mathrm{U}$ \\
\hline \multicolumn{2}{|c|}{ Total exceedences by element } & & 8 & 4 & 3 & 4 & 10 & 4 \\
\hline
\end{tabular}




\section{Summary}

Trace-element and Rn concentrations in groundwater were assessed for samples collected between 1992 and 2003 in principal and other aquifers across the United States as part of the U.S. Geological Survey National Water-Quality Assessment Program (NAWQA). Water samples used for this study were collected primarily from shallow wells installed near the water table in particular land-use settings and from deeper public and domestic drinking-water wells. This study, the first comprehensive national assessment of NAWQA trace elements in groundwater, compares concentrations of trace elements at analytical reporting levels to assess occurrence and to identify geographic areas where trace elements exceed human-health benchmarks (HHBs) and may pose a humanhealth concern. The dataset contains trace element data from 5,183 wells and represents more than 40 principal and other aquifers. Trace elements measured include aluminum (Al), antimony $(\mathrm{Sb})$, arsenic $(\mathrm{As})$, barium $(\mathrm{Ba})$, beryllium $(\mathrm{Be})$, boron (B), cadmium (Cd), chromium (Cr), cobalt (Co), copper $(\mathrm{Cu})$, iron $(\mathrm{Fe})$, lead $(\mathrm{Pb})$, lithium $(\mathrm{Li})$, manganese $(\mathrm{Mn})$, molybdenum (Mo), nickel (Ni), selenium (Se), silver (Ag), strontium $(\mathrm{Sr})$, thallium $(\mathrm{Tl})$, uranium $(\mathrm{U})$, vanadium $(\mathrm{V})$, and zinc ( $\mathrm{Zn})$. Radon (Rn) gas also was measured and is included in the data analysis.

Climate had an important influence on the occurrence and distribution of trace elements in groundwater. Concentrations of trace elements were commonly greater in the dry regions of the United States than in humid regions. In particular, trace elements that form oxyanions or ion complexes, such as As, $\mathrm{Ba}, \mathrm{B}, \mathrm{Cr}, \mathrm{Mo}, \mathrm{Se}, \mathrm{Sr}, \mathrm{U}$, and $\mathrm{V}$, were greater in groundwater in dry regions than in more humid regions. $\mathrm{Cu}, \mathrm{Ni}$, and $\mathrm{Zn}$ also were greater in dry regions. By contrast, concentrations of elements that are mobile in anoxic and (or) low-pH groundwater, such as $\mathrm{Al}, \mathrm{Co}, \mathrm{Fe}, \mathrm{Pb}$, and $\mathrm{Mn}$, were greater in humid regions.

Samples from drinking-water wells in dry regions had greater concentrations of $\mathrm{As}, \mathrm{Ba}, \mathrm{Pb}, \mathrm{Li}, \mathrm{Sr}, \mathrm{V}$, and $\mathrm{Zn}$, than samples from monitoring wells. In humid regions, however, concentrations of most trace elements were greater in monitoring wells than in drinking-water wells; the exceptions were $\mathrm{Cu}, \mathrm{Pb}, \mathrm{Zn}$, and $\mathrm{Rn} . \mathrm{Cu}, \mathrm{Pb}$, and $\mathrm{Zn}$ are common trace elements in pumps and pipes used in the construction of drinking-water wells, and contamination from these sources may have contributed to their concentrations. Al, Sb, Ba, B, $\mathrm{Cr}, \mathrm{Co}, \mathrm{Fe}, \mathrm{Mn}, \mathrm{Mo}, \mathrm{Ni}, \mathrm{Se}, \mathrm{Sr}$, and $\mathrm{U}$ concentrations were all greater in monitoring wells than in drinking-water wells in the humid regions.

Groundwater from wells in agricultural settings had greater concentrations of some trace elements, such as As, Mo, and $\mathrm{U}$, than from wells in urban settings. Concentrations of $\mathrm{DO}$ and $\mathrm{pH}$ also were greater in groundwater from agricultural wells than from urban wells. Significantly greater concentrations of $\mathrm{B}, \mathrm{Cr}, \mathrm{Se}, \mathrm{Ag}, \mathrm{Sr}$, and $\mathrm{V}$ were found in agricultural wells in the dry regions. Groundwater from urban wells had greater concentrations of $\mathrm{Co}, \mathrm{Fe}, \mathrm{Mn}$, and specific conductance than groundwater from agricultural wells.
Overall, groundwater in 19 percent of all wells (962 of $5,097)$ exceeded an HHB for at least one trace element, including $\mathrm{Sb}, \mathrm{As}, \mathrm{Ba}, \mathrm{Be}, \mathrm{B}, \mathrm{Cd}, \mathrm{Cr}, \mathrm{Cu}, \mathrm{Pb}, \mathrm{Mn}, \mathrm{Mo}, \mathrm{Ni}, \mathrm{Se}, \mathrm{Ag}$, $\mathrm{Sr}, \mathrm{Tl}, \mathrm{U}$, and $\mathrm{Zn}$. HHB or nonhealth-guideline exceedences were common in samples collected from wells in all aquifer groups across the United States. Water from wells in urban settings had greater rates of HHB exceedence than from wells in agricultural settings or wells in varied land-use areas (major aquifer studies). As a group, monitoring wells generally had greater benchmark or guideline-exceedence rates than domestic or public wells.

Mn occurred most often at concentrations greater than its HHB (12 percent), followed by As (7.0 percent), Sr ( 4.3 percent), U (4.0 percent), B (1.9 percent) and Mo (1.5 percent). Rn occurred at concentrations greater than the USEPA-proposed MCL of $300 \mathrm{pCi} / \mathrm{L}$ in 65 percent of samples, and 2.7 percent of Rn concentrations were greater than the USEPA-proposed AMCL of 4,000 pCi/L. In general, there were more exceedences of HHBs in groundwater in dry climates than in humid climates.

Trace-element contamination in groundwater far outpaces the concentrations of most other commonly assessed contaminants, such as VOCs, pesticides, and nitrate. One or more trace elements exceeded HHBs in samples from 13 percent of public-supply wells and 13 percent of domestic-supply wells; for pesticides and VOCs, for example, these rates were 2.2 percent or less. Nitrate exceeded its MCL in samples from 3 percent of public-supply wells and 7 percent of domesticsupply wells.

The geology of aquifers also is a major factor affecting trace-element occurrence in the United States. Eight major aquifer groups were characterized based on the type of geologic material and included (1) unconsolidated sand and gravel; (2) glacial unconsolidated sand and gravel; (3) sandstone; (4) crystalline rock; (5) sandstone and carbonate rock; (6) carbonate rock; (7) semiconsolidated sand; and (8) basaltic and other volcanic rock. The majority of the water samples and the largest percentages of HHB exceedences occurred in groundwater from unconsolidated sand and gravel (USG) and the glacial unconsolidated sand and gravel (GLA) aquifers. $\mathrm{As}, \mathrm{Fe}, \mathrm{Mn}$, and $\mathrm{U}$ were the most commonly occurring trace elements exceeding HHBs or nonhealth guidelines in both of these aquifer groups.

Field measurements of $\mathrm{pH}$ and redox were related to trace-element occurrence and concentrations. Generally, anoxic and mixed redox conditions with low $\mathrm{pH}$ were more common in wells in the humid parts of the United States, whereas oxic, higher $\mathrm{pH}$ conditions prevailed in wells in the dry regions. Redox and $\mathrm{pH}$ effects were evident for $\mathrm{As}, \mathrm{Cr}$, $\mathrm{Mo}$, and Se in all samples combined and from individual aquifer groups. Arsenic occurrence, for example, generally increased from oxic to anoxic groundwater when $\mathrm{pH}$ was less than 7; however, As occurrence was consistently high when $\mathrm{pH}$ was greater than 7 , which may be related to $\mathrm{pH}$-driven desorption. A similar pattern was seen for Mo and, to a lesser extent, Cr. In groundwater samples from the GLA aquifers, 
As concentrations increased as samples became increasingly anoxic and as $\mathrm{pH}$ increased. Also, the GLA aquifer group had the largest percentage of samples in the anoxic and mixed redox categories; thus redox-sensitive trace elements that are more mobile in anoxic conditions may occur more frequently. Arsenic, for example, exceeded $10 \mu \mathrm{g} / \mathrm{L}$ in 23 percent of samples of anoxic, high-pH groundwater and in 17 percent of samples of low-pH groundwater.

In general, older waters (mostly pre-1953) had more occurrences of trace elements, greater $\mathrm{pHs}$, were from deeper wells, and had lower concentrations of dissolved oxygen than younger waters (defined as waters containing a fraction younger than 1953). Most oxyanion-forming trace elements occurred more frequently in old groundwater. However, although $\mathrm{U}$ occurrence was greater in older water collected from dry-region aquifers, in humid-region aquifers, $U$ occurred more often in young water. This difference may be related to old, humid-region groundwater having lower concentrations of dissolved oxygen, a condition which can inhibit U mobility.

Logistic regression models were used to examine the relations of several trace elements to other chemical and ancillary data within selected major aquifer groups. The models showed that the $\mathrm{pH}$ and redox of groundwater were major controlling factors for many trace elements. In particular, low $\mathrm{pH}$ was found to be a significant factor in the occurrences of many cationic metals, such as $\mathrm{Al}, \mathrm{Fe}, \mathrm{Mn}$, and $\mathrm{Ni}$. In general, these metals, as well as $\mathrm{Cu}, \mathrm{Pb}$, and $\mathrm{Zn}$, adsorb more strongly to aquifer materials as $\mathrm{pH}$ increases. The models for As occurrence were dominated by co-occurrence with silica, Mo, and high $\mathrm{pH}$. About 12 percent of the samples with low silica or Mo had As concentrations greater than or equal to $1 \mu \mathrm{g} / \mathrm{L}$. This proportion increased to about 45 percent if either Mo or silica was present and further to about 85 percent if both Mo and silica were present. The effect of increased $\mathrm{pH}$ on As concentrations is likely to increase solubility through desorption.

Co-occurrence of trace elements also was addressed by focusing on those that exceeded HHBs in any given sample. For this analysis, 2,714 samples that had data for $\mathrm{Sb}$, As, $\mathrm{Ba}$, $\mathrm{Be}, \mathrm{Cd}, \mathrm{Cr}, \mathrm{Cu}, \mathrm{Pb}, \mathrm{Mn}, \mathrm{Mo}, \mathrm{Ni}, \mathrm{Se}, \mathrm{Ag}, \mathrm{U}$, and $\mathrm{Zn}$ were used. Because concentrations of Rn exceeded the USEPA-proposed MCL of $300 \mathrm{pCi} / \mathrm{L}$ in nearly 70 percent of samples, it would co-occur with most trace elements. For all selected samples from all aquifer groups, 21 percent (572 of 2,714 wells) had HHB exceedences of one or more trace elements. This was similar to the 19-percent (962 of 5,097 wells) rate of HHB exceedence for the complete dataset. Of the 2,714 wells, 62 (2.3 percent) had two or more trace elements that exceeded HHBs.

Multiple exceedences of HHBs occurred most often in the USG aquifer group. Of all of the samples with multiple exceedences, 50 of the 62 were from samples from the USG. The overall rate of multiple HHB exceedences in samples from the USG aquifer group was 4.2 percent and was dominated by combinations of As, Mn, and U. Eighty percent involved at least As and $\mathrm{Mn}, \mathrm{Mn}$ and $\mathrm{U}$, or As and $\mathrm{U}$.
Forty-two percent were only As and Mn, 18 percent were U and $\mathrm{Mn}$, and 8 percent were As and U. Mo was involved in 22 percent of the mixtures overall, and mostly in conjunction with As and $\mathrm{U}$.

$\mathrm{B}$ and $\mathrm{Sr}$ were measured in a subset of 819 samples (fewer samples than most trace elements) and sometimes cooccurred with other trace elements at concentrations greater than HHBs. These mixtures were primarily in samples from the USG aquifer group.

\section{Acknowledgments}

The authors wish to thank several USGS employees who provided guidance to this study: Neil Dubrovsky, Dennis Wentz, B. Thomas Nolan, Patricia Toccalino, William Wilber, Michael Yurewicz, and Jeffrey Deacon. The authors also thank Michael Rosen, Stephen Hinkle, and Stewart Clark for their technical reviews; and the Pembroke Publishing Service Center for the following support: Christine Mendelsohn for illustrations, Mary Ashman for editing, and Ann Marie Squillacci for layout and design.

\section{References Cited}

Anning, D.W., Bauch, N.J., Gerner, S.J., Flynn, M.E., Hamlin, S.N., Moore, S.J., Schaefer, D.H., Anderholm, S.K., and Spangler, L.E., 2007, Dissolved solids in basinfill aquifers and streams in the Southwestern United States: U.S. Geological Survey Scientific Investigations Report 2007-5315, $168 \mathrm{p}$.

Apodaca, L.E., Mueller, D.K., and Koterba, M.T., 2006, Review of trace element blank and replicate data collected in ground and surface water for the National Water-Quality Assessment Program, 1991-2002: U.S. Geological Survey Scientific Investigations Report 2006-5093, 32 p.

Ayotte, J.D., Flanagan, S.M., and Morrow, W.J., 2007, Occurrence of uranium and ${ }^{222}$ radon in glacial and bedrock aquifer systems in the northern United States, 1993-2003: U.S. Geological Survey Scientific Investigations Report 2007-5037, 84 p.

Ayotte, J.D., Montgomery, D.L., Flanagan, S.M., and Robinson, K.W., 2003, Arsenic in groundwater in eastern New England-Occurrence, controls, and human health implications: Environmental Science and Technology, v. 37 , no. 10 , p. $2075-2083$.

Ayotte, J.D., Szabo, Zoltan, Focazio, M.J., and Eberts, S.M., 2011, Effects of human-induced alteration of groundwater flow on concentrations of naturally-occurring trace elements at water-supply wells: Applied Geochemistry, v. 26, no. 5, p. 747-762. 
Back, William, Rosenshein, J.S., and Seaber, P.R., eds., 1988, Hydrogeology: Boulder, Colo., Geological Society of America, v. O-2, 524 p.

Bartos, T.T., Miller, C.A., Norris, J.R., Gamper, M.E., and Hallberg, L.L., 2005, Water-quality characteristics of Quaternary unconsolidated-deposit aquifers and Lower Tertiary aquifers of the Bighorn Basin, Wyoming and Montana, 1999-2001: U.S. Geological Survey Scientific Investigations Report 2004-5252, 155 p.

Bell, R.W., and Williamson, A.K., 2006, Data delivery and mapping over the Web-National Water-Quality Assessment Data Warehouse: U.S. Geological Survey Fact Sheet 2006-3101, 6 p.

Böhlke, J.K., 2002, Groundwater recharge and agricultural contamination: Hydrogeology Journal, v. 10, no. 1, p. 153-179.

Cantor, K.P., 1997, Drinking water and cancer: Cancer Causes and Control, v. 8, no. 3, p. 292-308.

Chapelle, F.H., Bradley, P.M., Lovley, D.R., O’Neill, K., and Landmeyer, J.E., 2002, Rapid evolution of redox processes in a petroleum hydrocarbon-contaminated aquifer: Ground Water, v. 40, no. 4, p. 353-360.

Chapelle, F.H., McMahon, P.B., Dubrovsky, N.M., Fujii, R.F., Oaksford, E.T., and Vroblesky, D.A., 1995, Deducing the distribution of terminal electron-accepting processes in hydrologically diverse groundwater systems: Water Resources Research, v. 31, no. 2, p. 359-371.

Chappell, W.R., Abernathy, C.O., and Calderon, R.L., eds., 2001, Arsenic exposure and health effects IV: New York, Elsevier Science, Ltd., 467 p.

Childress, C.J.O., Foreman, W.T., Connor, B.F., and Maloney, T.J., 1999, New reporting procedures based on long-term method detection levels and some considerations for interpretations of water-quality data provided by the U.S. Geological Survey National Water Quality Laboratory: U.S. Geological Survey Open-File Report 99-193, 19 p.

Chrosniak, L.D., Smith, L.N., McDonald, C.G., Jones, B.F., and Flinn, J.M., 2006, Effects of enhanced zinc and copper in drinking water on spatial memory and fear conditioning: Journal of Geochemical Exploration, v. 88, no. 1-3, p. $91-94$.

Commission for Environmental Cooperation Working Group, 1997, Ecological regions of North America-Toward a common perspective: Commission for Environmental Cooperation, $71 \mathrm{p}$.

D’Angelo, D., Norton, S.A., and Loiselle, M.C., 1996, Historical uses and fate of arsenic in Maine: Orono, Maine, University of Maine Water Research Institute Completion Report, 24 p.
deLemos, J.L., Bostick, B.C., Renshaw, C.E., Stürup, S., and Feng, X., 2006, Landfill-stimulated iron reduction and arsenic release at the Coakley Superfund Site $(\mathrm{NH})$ : Environmental Science and Technology, v. 40, no. 1, p. $67-73$.

DeSimone, L.A., 2009, Quality of water from domestic wells in principal aquifers of the United States, 1991-2004: U.S. Geological Survey Scientific Investigations Report 2008-5227, 139 p.

Deverel, S.J., and Millard, S.P., 1988, Distribution and mobility of selenium and other trace elements in shallow groundwater of the western San Joaquin Valley, California: Environmental Science and Technology, v. 22, no. 6, p. 697-702.

Drever, J.I., 1988, The geochemistry of natural waters (2d ed.): Englewood Cliffs, N.J., Prentice-Hall, 437 p.

Dubrovsky, N.M., Burow, K.R., Clark, G.M., Gronberg, J.M., Hamilton P.A., Hitt, K.J., Mueller, D.K., Munn, M.D., Nolan, B.T., Puckett, L.J., Rupert, M.G., Short, T.M., Spahr, N.E., Sprague, L.A., and Wilber, W.G., 2010, The quality of our Nation's waters - Nutrients in the Nation's streams and groundwater, 1992-2004: U.S. Geological Survey Circular $1350,174 \mathrm{p}$.

Dubrovsky, N.M., Deverel, S.J., and Gilliom, R.J., 1993, Multiscale approach to regional ground water quality assessment: Selenium in the San Joaquin Valley, California, in Alley, W.M., ed., Regional Ground Water Quality: New York, Van Nostrand Reinhold, p. 537-562.

Dubrovsky, N.M., Neil, J.M., Welker, M.C., and Evenson, K.D., 1991, Geochemical relations and distribution of selected trace elements in ground water of the northern part of the western San Joaquin Valley, California: U.S. Geological Survey Open-File Report 90-108, 55 p.

Eberts, S.M., Erwin, M.L., and Hamilton, P.A., 2005, Assessing the vulnerability of public-supply wells to contamination from urban, agricultural and natural sources: Reston, Va., U.S. Geological Survey Fact Sheet 2005-3022, p. 4.

Edmunds, M., and Smedley, P.L., 2005, Fluoride in natural waters-Occurrence, controls, and health aspects, in Selinus, O., Alloway, B.J., Centeno, J.A., Finkleman, R.B., Fuge, R., Lindh, U., and Smedley, P.L., eds., Essentials of medical geology - Impacts of the natural environment on public health: Amsterdam, Elsevier, p. 301-329.

Fahlquist, L., and Ardis, A.F., 2004, Quality of water in the Trinity and Edwards Aquifers, south-central Texas, 1996-98: U.S. Geological Survey Scientific Investigations Report 2004-5201, 17 p. 
Faires, L.M., 1993, Methods of analysis by the U.S. Geological Survey National Water Quality LaboratoryDetermination of metals in water by inductively coupled plasma-mass spectrometry: U.S. Geological Survey OpenFile Report 92-634, 28 p.

Fishman, M.J., and Friedman, L.C., 1989, Methods for determination of inorganic and organic constituents in water and fluvial sediments: U.S. Geological Survey Techniques of Water-Resources Investigations, book 5, chap. A1, 545 p.

Focazio, M.J., Szabo, Zoltan, Kraemer, T.F., Mullin, A.H., Barringer, T.H., and dePaul, V.T., 2001, Occurrence of selected radionuclides in ground water used for drinking water in the United States: U.S. Geological Survey WaterResources Investigations Report 00-4273, 40 p.

Freeze, R.A., and Cherry, J.A., 1979, Groundwater (1st ed.): New York, Prentice-Hall, 604 p.

Froelich, P.N., Klinkhammer, G.P., Bender, M.L., Luedtke, N.A., Heath, G.R., Cullen, D., Dauphin, P., Hammond, D., Hartman, B., and Maynard, V., 1979, Early oxidation of organic matter in pelagic sediments of the eastern equatorial Atlantic - Suboxic diagenesis: Geochimica et Cosmochimica Acta, v. 43, no. 7, p. 1075-1090.

Fujii, R.F., and Swain, W.C., 1995, Areal distribution of trace elements, salinity, and major ions in shallow ground water, Tulare Basin, southern San Joaquin Valley, California: U.S. Geological Survey Water-Resources Investigations Report 95-4048, $67 \mathrm{p}$.

Garbarino, J.R., 1999, Methods of analysis by the U.S. Geological Survey National Water Quality LaboratoryDetermination of dissolved arsenic, boron, lithium, selenium, strontium, thallium, and vanadium using inductively coupled plasma-mass spectrometry: U.S. Geological Survey Open-File Report 99-093, 31 p.

Gilliom, R.J., Alley, W.M., and Gurtz, M.E., 1995, Design of the national water-quality assessment program: occurrence and distribution of water-quality conditions: U.S. Geological Survey Circular 1112, 33 p.

Gilliom, R.J., Barbash, J.E., Crawford, C.G., Hamilton, P.A., Martin, J.D., Nakagaki, N., Nowell, L.H., Scott, J.C., Stackelberg, P.E., Thelin, G.P., and Wolock, D.M., 2006, The quality of our Nation's waters-Pesticides in the Nation's streams and ground water, 1992-2001: U.S. Geological Survey Circular 1291, 172 p.

Groschen, G.E., Arnold, T.L., Morrow, W.J., and Warner, K.L., 2008, Occurrence and distribution of iron, manganese, and selected trace elements in ground water in the glacial aquifer system of the northern United States: U.S. Geological Survey Scientific Investigations Report 2008-5006, 89 p.
Haglund, B., Ryckenberg, K., Selinus, O., and Dahlquist, G., 1996, Evidence of a relationship between childhood-onset type I diabetes and low groundwater concentration of zinc: Diabetes Care, v. 19 , no. 8, p. 873-875.

Hanshaw, B.B., and Back, William, 1979, Major geochemical processes in the evolution of carbonate-aquifer systems: Journal of Hydrology, v. 43, no. 1-4, p. 287-312.

Helsel, D.R., 2005, Nondetects and data analysis: Statistics for censored environmental data (1st ed.): New York, John Wiley and Sons, $250 \mathrm{p}$.

Helsel, D.R., and Hirsch, R.M., 1992, Statistical methods in water resources: New York, Elsevier Science Company, Inc., $522 \mathrm{p}$.

Hem, J.D., 1985, Study and interpretation of the chemical characteristics of natural water ( $3 \mathrm{~d}$ ed.): U.S. Geological Survey Water-Supply Paper 2254, 263 p. (Reprinted 1992.)

Hinkle, S.R., and Polette, D.J., 1999, Arsenic in ground water of the Willamette Basin, Oregon: U.S. Geological Survey Water-Resources Investigations Report 98-4025, 28 p.

Hopenhayn-Rich, C., Biggs, M.L., Fuchs, A., Bergoglio, R., Tello, E.E., Nicolli, H., and Smith, A.H., 1996, Bladder cancer mortality associated with arsenic in drinking water in Argentina: Epidemiology, v. 7, no. 2, p. 117-124.

Hosmer, D.W., and Lemeshow, S., 2000, Applied logistic regression $(2 \mathrm{~d}$ ed.): New York, John Wiley and Sons, 375 p.

Hutson, S.S., Barber, N.L., Kenny, J.F., Linsey, K.S., Lumia, D.S., and Maupin, M.A., 2004, Estimated use of water in the United States in 2000: U.S. Geological Survey Circular $1268,46 \mathrm{p}$.

Ivahnenko, Tamara, Szabo, Zoltan, and Gibs, Jacob, 2001, Changes in sample collection and analytical techniques and effects on retrospective comparability of low-level concentrations of trace elements in ground water: Water Research, v. 35 , no. 15 , p. $3611-3624$.

Ivahnenko, Tamara, Szabo, Zoltan, and Hall, G.S., 1996, Use of an ultra-clean sampling technique with inductively coupled plasma-mass spectrometry to determine trace-element concentrations in water from the Kirkwood-Cohansey aquifer system, Coastal Plain, New Jersey: U.S. Geological Survey Open-File Report 96-142, 37 p.

Jacks, G., 1993, Acid precipitation, in Alley, W.M., ed., Regional groundwater quality: New York, Van Nostrand Reinhold, p. 405-421. 
Karagas, M.R., Le, C.X., Morris, S., Blum, J., Lu, X., Spate, V., Carey, M., Stannard, V., Klaue, B., and Tosteson, T.D., 2001, Markers of low-level arsenic exposure for evaluating human cancer risks in a U.S. population: International Journal of Occupational Medicine and Environmental Health, v. 14, no. 2, p. 171-175.

Karagas, M.R., Tosteson, T.D., Blum, J., Morris, J.S., Baron, J.A., and Klaue, B., 1998, Design of an epidemiologic study of drinking water arsenic exposure and skin and bladder cancer risk in a U.S. population: Environmental Health Perspectives, v. 106, Supplement 4, p. 1047-1050.

Kendall, G.M., and Smith, T.J., 2002, Doses to organs and tissues from radon and its decay products: Journal of Radiological Protection, v. 22, p. 389-406.

Koterba, M.T., Wilde, F.D., and Lapham, W.W., 1995, Ground-water data-collection protocols and procedures for the National Water-Quality Assessment ProgramCollection and documentation of water-quality samples and related data: U.S. Geological Survey Open-File Report 95-399, $113 \mathrm{p}$.

Kresse, T., and Fazio, J., 2003, Occurrence of arsenic in ground waters of Arkansas and implications for source and release mechanisms: Arkansas Department of Environmental Quality, Water Quality Report WQ03-03-01, 35 p.

Lapham, W.W., Wilde, F.D., and Koterba, M.T., 1995, Ground-water data-collection protocols and procedures for the National Water-Quality Assessment Program-Selection, installation, and documentation of wells, and collection of related data: U.S. Geological Survey Open-File Report 95-398, 69 p.

Loiselle, M.C., Marvinney, R.G., and Smith, A.E., 2001, Spatial distribution of arsenic in groundwater in Maine, in Geological Society of America, 2001 Annual Meeting, Boston, Mass.

McLain, B., 1993, Methods of analysis by the U.S. Geological Survey National Water Quality Laboratory-Determination of chromium in water by graphite furnace atomic absorption spectrometry: U.S. Geological Survey Open-File Report 93-449, $16 \mathrm{p}$.

McLean, J.E., and Bledsoe, B.E., 1992, Behavior of metals in soils: U.S. Environmental Protection Agency Ground Water Issue EPA/540/S-92/018, 25 p.

McMahon, P.B., and Chapelle, F.H., 2008, Redox processes and water quality of selected principal aquifer systems: Ground Water, v. 46, no. 2, p. 259-271.

McMahon, P.B., Cowdery, T.K., Chapelle, F.H., and Jurgens, B.C., 2009, Redox conditions in selected principal aquifers of the United States: U.S. Geological Survey Fact Sheet 2009-3041, 6 p.
Meliker, J.R., Wahl, R.L., Cameron, L.L., and Nriagu, J.O., 2007, Arsenic in drinking water and cerebrovascular disease, diabetes mellitus, and kidney disease in MichiganA standardized mortality ratio analysis: Environmental Health, v. 6, no. 1, p. 4.

Meyer, F.W., 1989, Hydrogeology, ground-water movement, and subsurface storage in the Floridan aquifer system in southern Florida: U.S. Geological Survey Professional Paper 1403-G, 59 p.

Miller, J.A., ed., 2000, Ground water atlas of the United States: U.S. Geological Survey, Chapters archived online 1990-1999, accessed October 2005, at http://pubs.usgs.gov/ ha/ha730/index.html.

Mullin, A.H., and Wanty, R.B., 1991, A comparison of two techniques for radon-222 measurement in water samples: U.S. Geological Survey Bulletin 1971, p. 231-235.

Musgrove, M., and Banner, J.L., 2004, Controls on the spatial and temporal variability of vadose dripwater geochemistry -Edwards aquifer, central Texas: Geochimica et Cosmochimica Acta, v. 68, no. 5, p. 1007-1020.

National Academy of Sciences, 1999, Arsenic in drinking water: National Academy of Sciences Press, 273 p.

National Atmospheric Deposition Program, 2001, Hydrogen ion concentration as $\mathrm{pH}$ from measurements made at the field laboratories, 2001: National Atmospheric Deposition Program Office, Illinois State Water Survey, accessed October 11, 2007, at http://nadp.sws.uiuc.edu/isopleths/ maps2001/phfield.pdf.

Oetting, G.C., Banner, J.L., and Sharp, J.M., Jr., 1996, Regional controls on the geochemical evolution of saline groundwaters in the Edwards aquifer, central Texas: Journal of Hydrology, v. 181, no. 1-4, p. 251-283.

Paschke, S.S., 2007, Hydrogeologic settings and ground-water flow simulations for regional studies of the transport of anthropogenic and natural contaminants to public-supply wells-Studies begun in 2001: U.S. Geological Survey Professional Paper 1737-A, 244 p.

Peters, S.C., and Blum, J.D., 2003, The source and transport of arsenic in a bedrock aquifer, New Hampshire, USA: Applied Geochemistry, v. 18, p. 1773-1787.

Plummer, L.N., and Back, W., 1980, The mass balance approach-Application to interpreting the chemical evolution of hydrologic systems: American Journal of Science, v. 280, no. 2, p. 130-142.

Plummer, L.N., Michael, R.L., Thurman, E.M., and Glynn, P.D., 1993, Environmental tracers for age-dating young ground water, in Alley, W.M., ed., Regional ground-water quality: New York, Van Nostrand, p. 255-294. 
Practical Stats, 2007, SAS macro for robust ROS (CROS): Practical Stats, accessed May 2009, at http://www.practicalstats.com/nada/nada/downloads.html.

Prichard, H.M., and Gessell, T.F., 1977, Rapid measurement of Rn concentrations in water with a commercial liquid scintillation counter: Health Physics, v. 33, p. 577.

Robinson, G.R., Jr., and Ayotte, J.D., 2006, The influence of geology and land use on arsenic in stream sediments and ground waters in New England, USA: Applied Geochemistry, v. 21, no. 9, p. 1482-1497.

Robinson, G.R., Jr., and Ayotte, J.D., 2007, Rock-bound arsenic influences on ground water and sediment chemistry throughout New England: U.S. Geological Survey OpenFile Report 2007-1119, 16 p.

Rogers, R.J., 1989, Geochemical comparison of ground water in areas of New England, New York, and Pennsylvania: Ground Water, v. 27, p. 690-712.

Rosen, M.R., and Lapham, W.W., 2008, Introduction to the U.S. Geological Survey National Water-Quality Assessment (NAWQA) of ground water quality trends and comparison to other national programs: Journal of Environmental Quality, v. 37, no. 5, p. S-190-198.

Rupert, M.G., and Plummer, L.N., 2005, Ground-water flow direction, water quality, recharge sources, and age, Great Sand Dunes National Monument, south-central Colorado, 2000-2001: U.S. Geological Survey Scientific Investigations Report 2004-5027, 28 p.

Rutherford, D.W., Bednar, A.J., Garbarino, J.R., Needham, R., Staver, K.W., and Wershaw, R.L., 2003, Environmental fate of roxarsone in poultry litter-Part II. Mobility of arsenic in soils amended with poultry litter: Environmental Science and Technology, v. 37, no. 8, p. 1515-1520.

Ryker, S.J., and Small, M.J., 2008, Combining occurrence and toxicity information to identify priorities for drinking-water mixture research: Risk Analysis, v. 28, no. 3, p. 653-666.

Salbu, Brit, and Steinnes, Eiliv, 1994, Trace elements in natural waters: Boca Raton, Fla., CRC Press, 302 p.

SAS Institute, 1999, SAS/STAT online user's guide, Version 8: SAS Institute accessed October 17, 2006, at http://v8doc.sas.com/sashtml/.

Schaefer, D.H., Thiros, S.A., and Rosen, M.R., 2006, Groundwater quality in the carbonate-rock aquifer of the Great Basin, Nevada and Utah, 2003: U.S. Geological Survey Scientific Investigations Report 2005-5232, 32 p.

Scott, J.C., 1990, Computerized stratified random siteselection approaches for design of a ground-water-quality sampling network: U.S. Geological Survey WaterResources Investigations Report 90-4101, 109 p.
Seiler, R.L., 2004, Temporal changes in water quality at a childhood leukemia cluster: Ground Water, v. 42, no. 3, p. 446-455.

Seiler, R.L., Skorupa, J.P., Naftz, D.L., and Nolan, B.T., 2003, Irrigation-induced contamination of water, sediment, and biota in the western United States-Synthesis of data from the National Irrigation Water Quality Program: U.S. Geological Survey Professional Paper 1655, 123 p.

Selinus, O., Alloway, B.J., Centeno, J.A., Finkleman, R.B., Fuge, R., Lindh, U., and Smedley, P.L., eds., 2005, Essentials of medical geology-Impacts of the natural environment on public health (1st ed.): Boston, Elsevier, 812 p.

Smedley, P.L., 2003, Arsenic in groundwater-South and east Asia, in Welch, A.H., and Stollenwerk, K.G., eds., Arsenic in ground water-Geochemistry and occurrence: Boston, Kluwer Academic Publishers, p. 179-209.

Smedley, P.L., and Kinniburgh, D.G., 2002, A review of the source, behaviour, and distribution of arsenic in natural waters: Applied Geochemistry, v. 17, p. 517-568.

Smedley, P.L., Kinniburgh, D.G., Huq, I., Zhen-dong, L., and Nicolli, H.B., 2001, International perspective on naturally occurring arsenic problems in ground water, in Chappell, W.R., Abernathy, C.O., and Calderon, R.L., eds., Arsenic exposure and health effects IV (1st ed.): New York, Elsevier Science, p. 9-26.

Stollenwerk, K.G., 2003, Geochemical processes controlling transport of arsenic in groundwater-A review of adsorption, in Welch, A.H., and Stollenwerk, K.G., eds., Arsenic in ground water: Geochemistry and occurrence: Boston, Kluwer Academic Publishers, p. 67-100.

Stollenwerk, K.G., and Colman, J.A., 2004, Natural remediation of arsenic contaminated ground water associated with landfill leachate: U.S. Geological Survey Fact Sheet 2004-3057, 4 p.

Stolz, J.F., Perera, E., Kilonzo, B., Kail, B., Crable, B., Fisher, E., Ranganathan, M., Wormer, L., and Basu, P., 2007, Biotransformation of 3-nitro-4-hydroxybenzene arsonic acid (Roxarsone) and release of inorganic arsenic by clostridium species: Environmental Science and Technology, v. 41, no. 3 , p. $818-823$.

Thiros, S.A., and Manning, A.H., 2004, Quality and sources of ground water used for public supply in Salt Lake Valley, Salt Lake County, Utah, 2001: U.S. Geological Survey Water-Resources Investigations Report 03-4325, 107 p.

Thomas, M.A., 2003, Arsenic in midwestern glacial deposits-Occurrence and relation to selected hydrogeologic and geochemical factors: U.S. Geological Survey WaterResources Investigations Report 03-4228, 36 p. 
Thomas, M.A., 2007, The association of arsenic with redox conditions, depth, and ground-water age in the glacial aquifer system of the northern United States: U.S. Geological Survey Scientific Investigations Report 2007-5036, 26 p.

Toccalino, P.L., and Norman, J.E., 2006, Health-based screening levels to evaluate U.S. Geological Survey ground water quality data: Risk Analysis, v. 26, no. 5, p. 1339-1348.

Toccalino, P.L., Norman, J.E., and Hitt, K.J., 2010, Quality of source water from public-supply wells in the United States, 1993-2007: U.S. Geological Survey Scientific Investigations Report 2010-5024, 206 p.

Tourtelot, H.A., 1956, Radioactivity and uranium content of some Cretaceous shales, central Great Plains: American Association of Petroleum Geologists Bulletin v. 40, no. 1, p. $62-83$.

U.S. Environmental Protection Agency, 2004, 2004 edition of the drinking water standards and health advisories: U.S. Environmental Protection Agency Office of Water, EPA 822-R-04-005, $12 \mathrm{p}$.

U.S. Environmental Protection Agency, 2010, Radon in drinking water: U.S. Environmental Protection Agency, accessed May 10, 2010, at http://www.epa.gov/radon/rnwater.html.

U.S. Geological Survey, 2003, Principal aquifers of the 48 conterminous United States, Hawaii, Puerto Rico, and the U.S. Virgin Islands: U.S. Geological Survey, accessed October 2005, at http://www.nationalatlas.gov/mld/aquifrp. html.

Walker, M., Seiler, R.L., and Meinert, M., 2008, Effectiveness of household reverse-osmosis systems in a western U.S. region with high arsenic in groundwater: Science of the Total Environment, v. 389, no. 2-3, p. 245-252.

Warner, K.L., 2001, Arsenic in glacial drift aquifers and the implication for drinking water, Lower Illinois River Basin: Ground Water, v. 39, no. 3, p. 433-442.
Warner, K.L., and Arnold, T.L., 2006, Framework for regional synthesis of water-quality data for the glacial aquifer system in the United States: U.S. Geological Survey Scientific Investigations Report 2005-5223, 6 p.

Wasserman, G.A., Liu, X., Parvez, F., Ahsan, H., Levy, D., Factor-Litvak, P., Kline, J., van Geen, A., Slavkovich, V., Lolacono, N.J., Cheng, Z., Zheng, Y., and Graziano, J.H., 2006, Water manganese exposure and children's intellectual function in Araihazar, Bangladesh: Environmental Health Perspectives, v. 114, no. 1, p. 124-129.

Welch, A.H., and Lico, M.S., 1998, Factors controlling As and $\mathrm{U}$ in shallow ground water, southern Carson Desert, Nevada: Applied Geochemistry, v. 13, no. 4, p. 521-539.

Welch, A.H., and Stollenwerk, K.G., eds., 2003, Arsenic in groundwater-Geochemistry and Occurrence: Boston, Kluwer Academic Publishers, 475 p.

Welch, A.H., Westjohn, D.B., Helsel, D.R., and Wanty, R.B., 2000, Arsenic in ground water of the United StatesOccurrence and geochemistry: Ground Water, v. 38, no. 4, p. 589-604.

Wood, W.W., and Fernandez, L.A., 1988, Volcanic rocks, in Back, W., Rosenshein, J.S., and Seaber, P.R., eds., The geology of North America: Boulder, Colo., Geological Society of America, p. 353-365.

Wu, M.M., Kuo, T.L., Hwang, Y.H., and Chen, C.J., 1989, Dose-response relation between arsenic concentration in well water and mortality from cancers and vascular diseases: American Journal of Epidemiology, v. 130, no. 6, p. $1123-1132$.

Zogorski, J.S., Carter, J.M., Ivahnenko, T., Lapham, W.W., Moran, M.J., Rowe, B.L., Squillace, P.J., and Toccalino, P.L., 2006, The quality of our Nation's waters-Volatile organic compounds in the Nation's ground water and drinking-water supply wells: U.S. Geological Survey Circular 1292, $101 \mathrm{p}$. 
THIS PAGE INTENTIONALLY LEFT BLANK 
Appendixes 1-5 
Appendix 1. Selected national-scale studies of trace elements in groundwater.

[As, arsenic; $\mathrm{Cd}$, cadmium; F, fluoride; $\mathrm{Hg}$, mercury; Pb, lead; Po, polonium; Ra, radium; U, uranium]

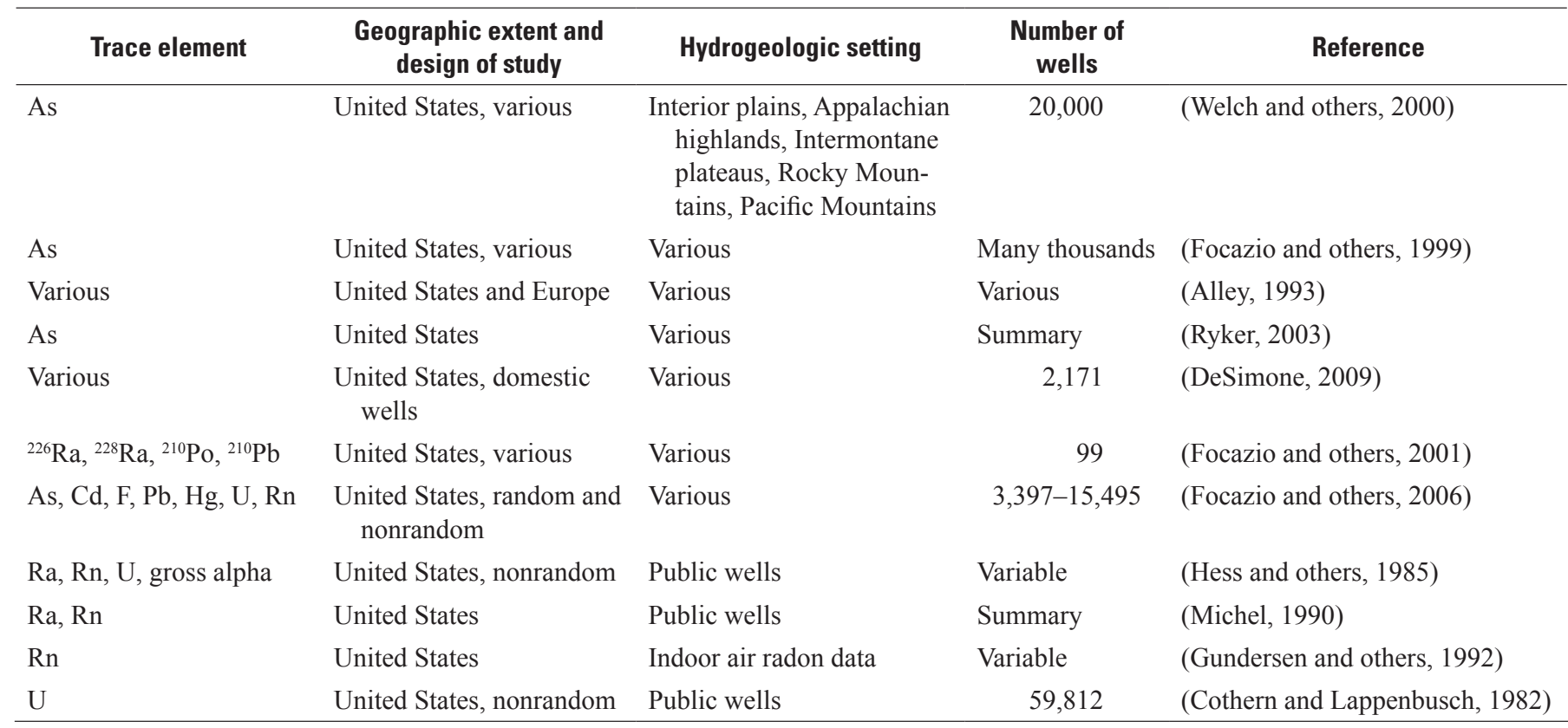

\section{References Cited}

Alley, W.M., 1993, Regional ground-water quality: Van Nostrand Reinhold Company.

Cothern, C.R., and Lappenbusch, W.L., 1982, Occurrence of uranium in drinking water in the U.S.: Health Physics, v. 45, no. 1, p. 89-99.

DeSimone, L.A., 2009, Quality of water from domestic wells in principal aquifers of the United States, 1991-2004: U.S. Geological Survey Scientific Investigations Report 2008-5227, 139 p.

Focazio, M.J., Szabo, Z., Kraemer, T.F., Mullin, A.H., Barringer, T.H., and dePaul, V.T., 2001, Occurrence of selected radionuclides in ground water used for drinking water in the United States: U.S. Geological Survey Water-Resources Investigations Report 00-4273, 40 p.

Focazio, M.J., Tipton, D., Shapiro, S.D., and Geiger, L.H., 2006, The chemical quality of self-supplied domestic well water in the United States: Ground Water Monitoring \& Remediation, v. 26, no. 3, p. 92-104.

Focazio, M.J., Welch, A.H., Watkins, S.A., Helsel, D.R., and Horn, M.A., 1999, A retrospective analysis on the occurrence of arsenic in ground-water resources of the United States and limitations in drinking-water-supply characterizations: U.S. Geological Survey Water-Resources Investigations Report 99-4279, 21 p.

Gundersen, L.C.S., Schumann, R.R., Otton, J.K., Owen, D.E., Dubiel, R.F., and Dickinson, K.A., 1992, Geology of radon in the United States, in Gates, A.E., and Gundersen, L.C.S., eds., Geologic controls on radon: Geological Society of America Special Paper, p. 1-16.

Hess, C.T., Michael, J., Horton, T.R., Prichard, H.M., and Coniglio, W.A., 1985, The occurrence of radioactivity in public water supplies in the United States: Journal of Health Physics, v. 48, no. 5, p. 553-586.

Michel, J., 1990, Relationship of radium and radon with geological formations, in Cothern, C.R., and Rebers, P., eds., Radon, radium, and uranium in drinking water (2nd ed.): Chelsea, Mich., Lewis Publishers.

Ryker, S.J., 2003, Arsenic in ground water used for drinking water in the United States, in Welch, A.H., and Stollenwerk, K.G., eds., Arsenic in ground water: Boston, Kluwer.

Welch, A.H., Westjohn, D.B., Helsel, D.R., and Wanty, R.B., 2000, Arsenic in ground water of the United States-Occurrence and geochemistry: Ground Water, v. 38, no. 4, p. 589-604. 
Appendix 2. Wells sampled by the NAWOA Program, 1992-2003, by study type, land use, major aquifer group, and aquifer name.

[Aquifer number shown on figure 3. Number of wells = 5,147 of 5,183 (36 are missing well-depth data); usg, unconsolidated sand and gravel; gla, glacial unconsolidated sand and gravel; scs, semiconsolidated sand; san, sandstone; scr, sandstone and carbonate rock; car, carbonate rock; bav, basaltic and volcanic rock; igm, igneous and metamorphic rock]

\begin{tabular}{|c|c|c|c|c|c|}
\hline $\begin{array}{l}\text { Aquifer } \\
\text { number }\end{array}$ & Lithology & Aquifer name & $\begin{array}{l}\text { Study network } \\
\text { code }\end{array}$ & $\begin{array}{l}\text { Number of } \\
\text { wells }\end{array}$ & $\begin{array}{l}\text { Median well } \\
\text { depth }\end{array}$ \\
\hline 1 & usg & Basin and Range basin-fill aquifers & cazbluscr1 & 9 & 43 \\
\hline 1 & usg & Basin and Range basin-fill aquifers & cazbsus1a & 34 & 465 \\
\hline 1 & usg & Basin and Range basin-fill aquifers & cazbsus 2 & 29 & 330 \\
\hline 1 & usg & Basin and Range basin-fill aquifers & cazbsus3 & 19 & 264 \\
\hline 1 & usg & Basin and Range basin-fill aquifers & grsllusrc1 & 30 & 69 \\
\hline 1 & usg & Basin and Range basin-fill aquifers & grslsus 1a & 26 & 239 \\
\hline 1 & usg & Basin and Range basin-fill aquifers & grslsus1b & 29 & 240 \\
\hline 1 & usg & Basin and Range basin-fill aquifers & nvbrlusag1 & 20 & 19.5 \\
\hline 1 & usg & Basin and Range basin-fill aquifers & nvbrlusag2 & 10 & 18 \\
\hline 1 & usg & Basin and Range basin-fill aquifers & nvbrlusur1 & 28 & 30 \\
\hline 1 & usg & Basin and Range basin-fill aquifers & nvbrlusur2 & 27 & 29 \\
\hline 1 & usg & Basin and Range basin-fill aquifers & nvbrsus1 & 22 & 775 \\
\hline 1 & usg & Basin and Range basin-fill aquifers & nvbrsus2 & 18 & 394.5 \\
\hline 1 & usg & Basin and Range basin-fill aquifers & nvbrsus3 & 17 & 155 \\
\hline 2 & usg & California Coastal Basin aquifers & sanalusrc1 & 25 & 24 \\
\hline 2 & usg & California Coastal Basin aquifers & sanasus1 & 29 & 585 \\
\hline 2 & usg & California Coastal Basin aquifers & sanasus2 & 20 & 966 \\
\hline 2 & usg & California Coastal Basin aquifers & sanasus3 & 22 & 699.5 \\
\hline 3 & usg & Central Valley aquifer system & sacrluscr1 & 28 & 35 \\
\hline 3 & usg & Central Valley aquifer system & sacrlusrc1 & 19 & 63 \\
\hline 3 & usg & Central Valley aquifer system & sacrsus1 & 31 & 150 \\
\hline 3 & usg & Central Valley aquifer system & sanjluscr1 & 18 & 145 \\
\hline 3 & usg & Central Valley aquifer system & sanjlusor1 & 20 & 170 \\
\hline 3 & usg & Central Valley aquifer system & sanjlusor2 & 20 & 147.5 \\
\hline 3 & usg & Central Valley aquifer system & sanjsus 1 & 30 & 182 \\
\hline 4 & usg & Columbia Plateau basin-fill aquifers & ccptlusag1 & 8 & 31 \\
\hline 4 & usg & Columbia Plateau basin-fill aquifers & ccptlusag2 & 32 & 69.5 \\
\hline 4 & usg & Columbia Plateau basin-fill aquifers & ccptlusor1 & 31 & 48 \\
\hline 4 & usg & Columbia Plateau basin-fill aquifers & ccptsus $1 b$ & 13 & 90 \\
\hline 5 & usg & High Plains aquifer & cnbrsus2 & 27 & 47 \\
\hline 5 & usg & High Plains aquifer & hpgwlusag1 & 30 & 160 \\
\hline 5 & usg & High Plains aquifer & hpgwlusag2 & 29 & 170 \\
\hline 5 & usg & High Plains aquifer & hpgwlusur1 & 30 & 27.5 \\
\hline 5 & usg & High Plains aquifer & hpgwsusla & 74 & 262.5 \\
\hline 5 & usg & High Plains aquifer & hpgwsus $1 b$ & 48 & 201 \\
\hline 5 & usg & High Plains aquifer & hpgwsus1c & 104 & 207.5 \\
\hline 5 & usg & High Plains aquifer & hpgwsus2 & 20 & 73.5 \\
\hline 5 & usg & High Plains aquifer & hpgwsus4 & 27 & 190 \\
\hline 6 & usg & Mississippi River Valley alluvial aquifer & misesus 1 & 29 & 110 \\
\hline 6 & usg & Mississippi River Valley alluvial aquifer & misesus 3 & 24 & 102.5 \\
\hline
\end{tabular}


Appendix 2. Wells sampled by the NAWQA Program, 1992-2003, by study type, land use, major aquifer group, and aquifer name. -Continued

[Aquifer number shown on figure 3. Number of wells $=5,147$ of 5,183 (36 are missing well-depth data); usg, unconsolidated sand and gravel; gla, glacial unconsolidated sand and gravel; scs, semiconsolidated sand; san, sandstone; scr, sandstone and carbonate rock; car, carbonate rock; bav, basaltic and volcanic rock; igm, igneous and metamorphic rock]

\begin{tabular}{|c|c|c|c|c|c|}
\hline $\begin{array}{l}\text { Aquifer } \\
\text { number }\end{array}$ & Lithology & Aquifer name & $\begin{array}{c}\text { Study network } \\
\text { code }\end{array}$ & $\begin{array}{c}\text { Number of } \\
\text { wells }\end{array}$ & $\begin{array}{l}\text { Median well } \\
\text { depth }\end{array}$ \\
\hline 7 & usg & Northern Rocky Mountains Intermontane Basins aquifer & nroksus1 & 31 & 137 \\
\hline 7 & usg & Northern Rocky Mountains Intermontane Basins aquifer & nroksus2 & 30 & 60 \\
\hline 8 & usg & Rio Grande aquifer system & rioglusag1 & 30 & 20 \\
\hline 8 & usg & Rio Grande aquifer system & riogluscr1 & 35 & 20 \\
\hline 8 & usg & Rio Grande aquifer system & rioglusur1 & 24 & 27 \\
\hline 8 & usg & Rio Grande aquifer system & riogsus 1 & 30 & 169 \\
\hline 9 & usg & Snake River Plain basin-fill aquifers & usnkluscr1 & 27 & 34 \\
\hline 9 & usg & Snake River Plain basin-fill aquifers & usnkluscr3 & 1 & 180 \\
\hline 9 & usg & Snake River Plain basin-fill aquifers & usnksus1 & 9 & 67 \\
\hline 9 & usg & Snake River Plain basin-fill aquifers & usnksus2 & 23 & 150 \\
\hline 9 & usg & Snake River Plain basin-fill aquifers & usnksus3 & 10 & 119 \\
\hline 10 & usg & Surficial aquifer system & acfblusag1 & 16 & 41.5 \\
\hline 10 & usg & Surficial aquifer system & acfblusfo1 & 4 & 57.5 \\
\hline 10 & usg & Surficial aquifer system & gaflluscr1 & 23 & 27 \\
\hline 10 & usg & Surficial aquifer system & gafllusur3 & 16 & 23.5 \\
\hline 10 & usg & Surficial aquifer system & gaflsus1 & 32 & 27.5 \\
\hline 10 & usg & Surficial aquifer system & miselusrc1 & 24 & 48.5 \\
\hline 10 & usg & Surficial aquifer system & santluscr1 & 30 & 18 \\
\hline 10 & usg & Surficial aquifer system & sofllusfo1 & 5 & 10 \\
\hline 10 & usg & Surficial aquifer system & sofllusor 1 & 31 & 13 \\
\hline 11 & usg & Willamette Lowland basin-fill aquifers & willsus1 & 70 & 60 \\
\hline 12 & gla & Glacial aquifer system & almnsus2 & 30 & 73 \\
\hline 12 & gla & Glacial aquifer system & connlusag1 & 40 & 21 \\
\hline 12 & gla & Glacial aquifer system & connlusfo1 & 40 & 17 \\
\hline 12 & gla & Glacial aquifer system & connlusur1 & 40 & 22 \\
\hline 12 & gla & Glacial aquifer system & delrsus3 & 16 & 114 \\
\hline 12 & gla & Glacial aquifer system & eiwaluscr1 & 31 & 18 \\
\hline 12 & gla & Glacial aquifer system & eiwalusrc1 & 30 & 23 \\
\hline 12 & gla & Glacial aquifer system & eiwasus2 & 32 & 52 \\
\hline 12 & gla & Glacial aquifer system & hdsnlusag1 & 14 & 19.5 \\
\hline 12 & gla & Glacial aquifer system & hdsnlusur1 & 27 & 29 \\
\hline 12 & gla & Glacial aquifer system & hdsnsus1 & 2 & 108 \\
\hline 12 & gla & Glacial aquifer system & leriluscr1 & 30 & 18 \\
\hline 12 & gla & Glacial aquifer system & lerilusrc1 & 30 & 25.5 \\
\hline 12 & gla & Glacial aquifer system & lerisus 1 & 27 & 90 \\
\hline 12 & gla & Glacial aquifer system & linjsus 1 & 1 & 152 \\
\hline 12 & gla & Glacial aquifer system & lirbluscr1 & 28 & 27.5 \\
\hline 12 & gla & Glacial aquifer system & lirbluscr2 & 29 & 20 \\
\hline 12 & gla & Glacial aquifer system & lirbsus1 & 30 & 245 \\
\hline 12 & gla & Glacial aquifer system & lirbsus2 & 30 & 50 \\
\hline 12 & gla & Glacial aquifer system & miamluscr1 & 26 & 25.5 \\
\hline
\end{tabular}


Appendix 2. Wells sampled by the NAWOA Program, 1992-2003, by study type, land use, major aquifer group, and aquifer name. -Continued

[Aquifer number shown on figure 3. Number of wells $=5,147$ of 5,183 (36 are missing well-depth data); usg, unconsolidated sand and gravel; gla, glacial unconsolidated sand and gravel; scs, semiconsolidated sand; san, sandstone; scr, sandstone and carbonate rock; car, carbonate rock; bav, basaltic and volcanic rock; igm, igneous and metamorphic rock]

\begin{tabular}{|c|c|c|c|c|c|}
\hline $\begin{array}{l}\text { Aquifer } \\
\text { number }\end{array}$ & Lithology & Aquifer name & $\begin{array}{c}\text { Study network } \\
\text { code }\end{array}$ & $\begin{array}{c}\text { Number of } \\
\text { wells }\end{array}$ & $\begin{array}{l}\text { Median well } \\
\text { depth }\end{array}$ \\
\hline 12 & gla & Glacial aquifer system & miamlusrc1 & 25 & 39 \\
\hline 12 & gla & Glacial aquifer system & miamsus1 & 30 & 60 \\
\hline 12 & gla & Glacial aquifer system & necblusrc1 & 29 & 23 \\
\hline 12 & gla & Glacial aquifer system & necbsus3 & 30 & 56 \\
\hline 12 & gla & Glacial aquifer system & pugtluscr1 & 22 & 28.5 \\
\hline 12 & gla & Glacial aquifer system & pugtlusrs1 & 27 & 47 \\
\hline 12 & gla & Glacial aquifer system & pugtsus1 & 30 & 66.5 \\
\hline 12 & gla & Glacial aquifer system & rednlusag1 & 26 & 25.5 \\
\hline 12 & gla & Glacial aquifer system & rednlusag2 & 20 & 15 \\
\hline 12 & gla & Glacial aquifer system & rednsus 1 & 27 & 40 \\
\hline 12 & gla & Glacial aquifer system & rednsus2 & 25 & 58 \\
\hline 12 & gla & Glacial aquifer system & rednsus3 & 15 & 37 \\
\hline 12 & gla & Glacial aquifer system & uirbluscr1 & 29 & 14 \\
\hline 12 & gla & Glacial aquifer system & uirblusrc1 & 26 & 29 \\
\hline 12 & gla & Glacial aquifer system & uirbsus1 & 27 & 72 \\
\hline 12 & gla & Glacial aquifer system & uirbsus2 & 23 & 45 \\
\hline 12 & gla & Glacial aquifer system & umisluscr1 & 29 & 25 \\
\hline 12 & gla & Glacial aquifer system & umislusfo1 & 15 & 19 \\
\hline 12 & gla & Glacial aquifer system & umislusrc1 & 30 & 19 \\
\hline 12 & gla & Glacial aquifer system & whitluscr1 & 23 & 28 \\
\hline 12 & gla & Glacial aquifer system & whitluscr2 & 20 & 22.5 \\
\hline 12 & gla & Glacial aquifer system & whitluscr3 & 24 & 20.5 \\
\hline 12 & gla & Glacial aquifer system & whitlusur1 & 25 & 29 \\
\hline 12 & gla & Glacial aquifer system & wmiclusag1 & 26 & 30 \\
\hline 12 & gla & Glacial aquifer system & wmiclusag2 & 30 & 42 \\
\hline 13 & gla & Unconsolidated-deposit aquifers (Alaska) & cooksusla & 29 & 90 \\
\hline 14 & $\operatorname{ses}$ & Coastal Lowlands aquifer system & acadluscr1 & 27 & 26 \\
\hline 14 & $\operatorname{scs}$ & Coastal Lowlands aquifer system & acadlusrc1 & 28 & 58.5 \\
\hline 14 & $\operatorname{scs}$ & Coastal Lowlands aquifer system & acadsus 1 & 30 & 140 \\
\hline 14 & $\operatorname{scs}$ & Coastal Lowlands aquifer system & acadsus2 & 30 & 115 \\
\hline 14 & $\operatorname{ses}$ & Coastal Lowlands aquifer system & trinsus3 & 23 & 138 \\
\hline 15 & $\operatorname{ses}$ & Mississippi Embayment aquifer system & miselusrc2 & 8 & 98 \\
\hline 15 & $\operatorname{scs}$ & Mississippi Embayment aquifer system & misesus2 & 30 & 675 \\
\hline 16 & $\operatorname{ses}$ & North Atlantic Coastal Plain aquifer system & albelusag1 & 17 & 12 \\
\hline 16 & $\operatorname{ses}$ & North Atlantic Coastal Plain aquifer system & albelusur1 & 14 & 62.5 \\
\hline 16 & $\operatorname{scs}$ & North Atlantic Coastal Plain aquifer system & albesus 1 & 11 & 20 \\
\hline 16 & $\operatorname{ses}$ & North Atlantic Coastal Plain aquifer system & albesus2 & 16 & 21.5 \\
\hline 16 & $\operatorname{scs}$ & North Atlantic Coastal Plain aquifer system & dlmvluscr1 & 28 & 21.5 \\
\hline 16 & $\operatorname{scs}$ & North Atlantic Coastal Plain aquifer system & dlmvsus1 & 27 & 45 \\
\hline 16 & $\operatorname{scs}$ & North Atlantic Coastal Plain aquifer system & linjluscr1 & 15 & 31 \\
\hline 16 & $\operatorname{scs}$ & North Atlantic Coastal Plain aquifer system & linjlusfo1 & 13 & 19 \\
\hline 16 & $\operatorname{ses}$ & North Atlantic Coastal Plain aquifer system & linjlusrc1 & 30 & 24 \\
\hline 16 & $\operatorname{ses}$ & North Atlantic Coastal Plain aquifer system & linjlusur1 & 20 & 24 \\
\hline 16 & $\operatorname{scs}$ & North Atlantic Coastal Plain aquifer system & linjsus2 & 30 & 100 \\
\hline
\end{tabular}


Appendix 2. Wells sampled by the NAWQA Program, 1992-2003, by study type, land use, major aquifer group, and aquifer name. -Continued

[Aquifer number shown on figure 3. Number of wells $=5,147$ of 5,183 (36 are missing well-depth data); usg, unconsolidated sand and gravel; gla, glacial unconsolidated sand and gravel; scs, semiconsolidated sand; san, sandstone; scr, sandstone and carbonate rock; car, carbonate rock; bav, basaltic and volcanic rock; igm, igneous and metamorphic rock]

\begin{tabular}{|c|c|c|c|c|c|}
\hline $\begin{array}{l}\text { Aquifer } \\
\text { number }\end{array}$ & Lithology & Aquifer name & $\begin{array}{c}\text { Study network } \\
\text { code }\end{array}$ & $\begin{array}{c}\text { Number of } \\
\text { wells }\end{array}$ & $\begin{array}{l}\text { Median well } \\
\text { depth }\end{array}$ \\
\hline 17 & scs & Southeastern Coastal Plain aquifer system & moblluscr1 & 29 & 35 \\
\hline 17 & $\operatorname{scs}$ & Southeastern Coastal Plain aquifer system & mobllusrc1 & 30 & 41.5 \\
\hline 17 & $\operatorname{scs}$ & Southeastern Coastal Plain aquifer system & moblsus1 & 31 & 165 \\
\hline 17 & $\operatorname{scs}$ & Southeastern Coastal Plain aquifer system & santlusrc1 & 30 & 19.5 \\
\hline 17 & $\operatorname{ses}$ & Southeastern Coastal Plain aquifer system & santsus 1 & 30 & 245 \\
\hline 18 & $\operatorname{scs}$ & Texas coastal uplands aquifer system & trinsus2 & 23 & 160 \\
\hline 19 & san & Cambrian-Ordovician aquifer system & umissus3 & 25 & 180 \\
\hline 19 & san & Cambrian-Ordovician aquifer system & umissus4 & 25 & 200 \\
\hline 19 & san & Cambrian-Ordovician aquifer system & wmicsus 1 & 29 & 170 \\
\hline 20 & san & Early Mesozoic basin aquifers & delrsus 1 & 30 & 160 \\
\hline 20 & san & Early Mesozoic basin aquifers & linjsus3 & 17 & 200 \\
\hline 20 & san & Early Mesozoic basin aquifers & potosus 2 & 20 & 148.5 \\
\hline 21 & san & Lower Tertiary aquifers & yellsus2 & 29 & 160 \\
\hline 22 & san & Pennsylvanian aquifers & almnlusmi1 & 30 & 83.5 \\
\hline 22 & san & Pennsylvanian aquifers & almnsus1 & 30 & 105 \\
\hline 22 & san & Pennsylvanian aquifers & kanalusmi1 & 28 & 76.5 \\
\hline 22 & san & Pennsylvanian aquifers & kanasus1 & 20 & 77.5 \\
\hline 22 & san & Pennsylvanian aquifers & whitluscr2 & 2 & 23 \\
\hline 23 & san & Valley and Ridge aquifers (sandstone) & delrsus2 & 30 & 192.5 \\
\hline 23 & san & Valley and Ridge aquifers (sandstone) & lsussus 1 & 29 & 155 \\
\hline 23 & san & Valley and Ridge aquifers (sandstone) & potolusag2 & 23 & 122 \\
\hline 23 & san & Valley and Ridge aquifers (sandstone) & potolusfo1 & 3 & 160 \\
\hline 23 & san & Valley and Ridge aquifers (sandstone) & utenluscr1 & 11 & 18 \\
\hline 24 & scr & Edwards-Trinity aquifer system & sctxlusrc1 & 30 & 261 \\
\hline 24 & scr & Edwards-Trinity aquifer system & sctxsus 1 & 19 & 335 \\
\hline 24 & scr & Edwards-Trinity aquifer system & sctxsus2 & 25 & 420 \\
\hline 24 & scr & Edwards-Trinity aquifer system & sctxsus 3 & 30 & 1,268 \\
\hline 24 & scr & Edwards-Trinity aquifer system & trinsus1 & 24 & 155 \\
\hline 25 & scr & Mississippian aquifers & kanasus1 & 10 & 191 \\
\hline 25 & scr & Mississippian aquifers & lerisus 1 & 1 & 120 \\
\hline 25 & scr & Mississippian aquifers & ltenlusag1 & 32 & 37.5 \\
\hline 25 & scr & Mississippian aquifers & 1tensus1 & 32 & 87 \\
\hline 25 & scr & Mississippian aquifers & 1tensus2 & 4 & 99 \\
\hline 26 & car & Biscayne aquifer & sofllusrc1 & 30 & 15 \\
\hline 26 & car & Biscayne aquifer & soflsus 1 & 30 & 99 \\
\hline
\end{tabular}


Appendix 2. Wells sampled by the NAWOA Program, 1992-2003, by study type, land use, major aquifer group, and aquifer name. -Continued

[Aquifer number shown on figure 3. Number of wells $=5,147$ of 5,183 (36 are missing well-depth data); usg, unconsolidated sand and gravel; gla, glacial unconsolidated sand and gravel; scs, semiconsolidated sand; san, sandstone; scr, sandstone and carbonate rock; car, carbonate rock; bav, basaltic and volcanic rock; igm, igneous and metamorphic rock]

\begin{tabular}{|c|c|c|c|c|c|}
\hline $\begin{array}{l}\text { Aquifer } \\
\text { number }\end{array}$ & Lithology & Aquifer name & $\begin{array}{c}\text { Study network } \\
\text { code }\end{array}$ & $\begin{array}{c}\text { Number of } \\
\text { wells }\end{array}$ & $\begin{array}{l}\text { Median well } \\
\text { depth }\end{array}$ \\
\hline 27 & car & Floridan aquifer system & acfblusag1 & 3 & 44 \\
\hline 27 & car & Floridan aquifer system & acfbsus 1 & 26 & 150 \\
\hline 27 & car & Floridan aquifer system & gaflsus1 & 4 & 69 \\
\hline 27 & car & Floridan aquifer system & santsus2 & 30 & 175 \\
\hline 28 & car & Ordovician aquifers & ltensus2 & 27 & 140 \\
\hline 29 & car & Ozark Plateaus aquifer system & ozrklusag1 & 20 & 167.5 \\
\hline 29 & car & Ozark Plateaus aquifer system & ozrklusag2 & 20 & 180 \\
\hline 29 & car & Ozark Plateaus aquifer system & ozrksus1 & 20 & $1,308.5$ \\
\hline 29 & car & Ozark Plateaus aquifer system & ozrksus $2 a$ & 30 & 196 \\
\hline 29 & car & Ozark Plateaus aquifer system & ozrksus3a & 13 & 140 \\
\hline 30 & car & Piedmont and Blue Ridge carbonate-rock aquifers & lsuslusag1 & 30 & 160 \\
\hline 31 & car & Silurian-Devonian aquifers & eiwasus1 & 33 & 225 \\
\hline 32 & car & Valley and Ridge aquifers (carbonate) & kanasus2 & 1 & 325 \\
\hline 32 & car & Valley and Ridge aquifers (carbonate) & 1suslusag2 & 30 & 172.5 \\
\hline 32 & car & Valley and Ridge aquifers (carbonate) & lsuslusag3 & 30 & 159 \\
\hline 32 & car & Valley and Ridge aquifers (carbonate) & 1suslusur1 & 20 & 108 \\
\hline 32 & car & Valley and Ridge aquifers (carbonate) & potolusag1 & 29 & 144 \\
\hline 32 & car & Valley and Ridge aquifers (carbonate) & potolusag2 & 1 & 280 \\
\hline 32 & car & Valley and Ridge aquifers (carbonate) & utenluscr1 & 19 & 16 \\
\hline 32 & car & Valley and Ridge aquifers (carbonate) & utensus1 & 30 & 227.5 \\
\hline 33 & bav & Columbia Plateau basaltic-rock aquifers & ccptlusag1 & 18 & 101.5 \\
\hline 33 & bav & Columbia Plateau basaltic-rock aquifers & ccptlusag2 & 17 & 157 \\
\hline 33 & bav & Columbia Plateau basaltic-rock aquifers & ccptlusor1 & 9 & 170 \\
\hline 33 & bav & Columbia Plateau basaltic-rock aquifers & ccptsus $1 b$ & 30 & 339 \\
\hline 34 & bav & Hawaiian volcanic-rock aquifers & oahusus 1 & 30 & 512 \\
\hline 35 & bav & Snake River Plain basaltic-rock aquifers & usnkluscr2 & 29 & 225 \\
\hline 35 & bav & Snake River Plain basaltic-rock aquifers & usnkluscr3 & 28 & 202.5 \\
\hline 35 & bav & Snake River Plain basaltic-rock aquifers & usnkluscr4 & 15 & 360 \\
\hline 35 & bav & Snake River Plain basaltic-rock aquifers & usnksus1 & 34 & 315 \\
\hline 35 & bav & Snake River Plain basaltic-rock aquifers & usnksus2 & 13 & 232 \\
\hline 36 & bav & Early Mesozoic basin aquifers (basalt and volcanic) & linjsus3 & 4 & 167.5 \\
\hline 36 & bav & Early Mesozoic basin aquifers (basalt and volcanic) & potosus 2 & 3 & 160 \\
\hline 37 & igm & New England crystalline-rock aquifers (unofficial name) & connsus 1 & 30 & 235 \\
\hline 37 & igm & New England crystalline-rock aquifers (unofficial name) & linjsus1 & 29 & 202 \\
\hline 37 & igm & New England crystalline-rock aquifers (unofficial name) & necbsus1 & 28 & 187.5 \\
\hline 37 & igm & New England crystalline-rock aquifers (unofficial name) & necbsus2 & 30 & 303 \\
\hline
\end{tabular}


Appendix 2. Wells sampled by the NAWQA Program, 1992-2003, by study type, land use, major aquifer group, and aquifer name. -Continued

[Aquifer number shown on figure 3. Number of wells $=5,147$ of 5,183 (36 are missing well-depth data); usg, unconsolidated sand and gravel; gla, glacial unconsolidated sand and gravel; scs, semiconsolidated sand; san, sandstone; scr, sandstone and carbonate rock; car, carbonate rock; bav, basaltic and volcanic rock; igm, igneous and metamorphic rock]

\begin{tabular}{|c|c|c|c|c|c|}
\hline $\begin{array}{l}\text { Aquifer } \\
\text { number }\end{array}$ & Lithology & Aquifer name & $\begin{array}{l}\text { Study network } \\
\text { code }\end{array}$ & $\begin{array}{l}\text { Number of } \\
\text { wells }\end{array}$ & $\begin{array}{l}\text { Median well } \\
\text { depth }\end{array}$ \\
\hline 38 & igm & Piedmont and Blue Ridge crystalline-rock aquifers & acfblusur1 & 21 & 31 \\
\hline 38 & igm & Piedmont and Blue Ridge crystalline-rock aquifers & kanasus2 & 29 & 205 \\
\hline 38 & igm & Piedmont and Blue Ridge crystalline-rock aquifers & 1sussus2 & 30 & 146.5 \\
\hline 38 & igm & Piedmont and Blue Ridge crystalline-rock aquifers & potosus1 & 25 & 142 \\
\hline 38 & igm & Piedmont and Blue Ridge crystalline-rock aquifers & santsus 3 & 30 & 200 \\
\hline 99 & igm & Rocky Mountain Front Range (unofficial name) & spltsus 1 & 27 & 225 \\
\hline 99 & san & Woodbine aquifer (not a principal aquifer) & trinlusur1 & 20 & 25.5 \\
\hline 99 & usg & $\begin{array}{l}\text { Stream-valley aquifers-Bighorn, Wind, Powder River basins } \\
\text { (unofficial name) }\end{array}$ & yelllusot1 & 29 & 15 \\
\hline 99 & usg & $\begin{array}{l}\text { Stream-valley aquifers-Bighorn, Wind, Powder River basins } \\
\text { (unofficial name) }\end{array}$ & yellsus 1 & 25 & 19 \\
\hline 99 & usg & Stream-valley aquifers-South Platte River (unofficial name) & spltluscr1 & 30 & 23 \\
\hline 99 & usg & Stream-valley aquifers-South Platte River (unofficial name) & spltlusrc1 & 30 & 27.5 \\
\hline 99 & usg & Stream-valley aquifers-Valley and Ridge (unofficial name) & potolusag2 & 1 & 71 \\
\hline 99 & usg & Stream-valley aquifers-Upper Colorado River (unofficial name) & ucollusrc1 & 25 & 24 \\
\hline 99 & usg & Stream-valley aquifers-Upper Colorado River (unofficial name) & ucolsus1 & 29 & 60 \\
\hline 99 & usg & Stream-valley aquifers-Upper Colorado River (unofficial name) & ucolsus2 & 13 & 49 \\
\hline
\end{tabular}




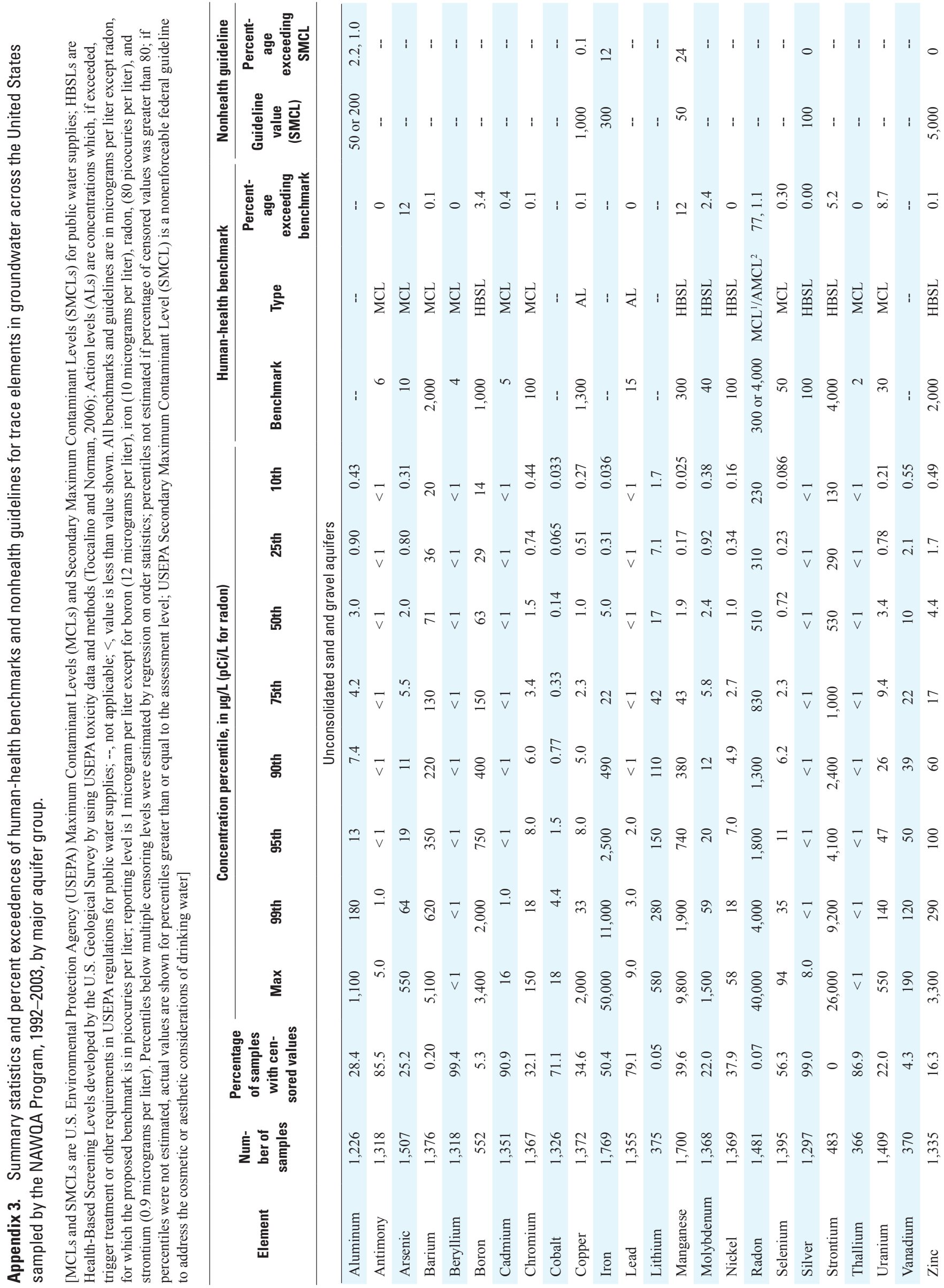




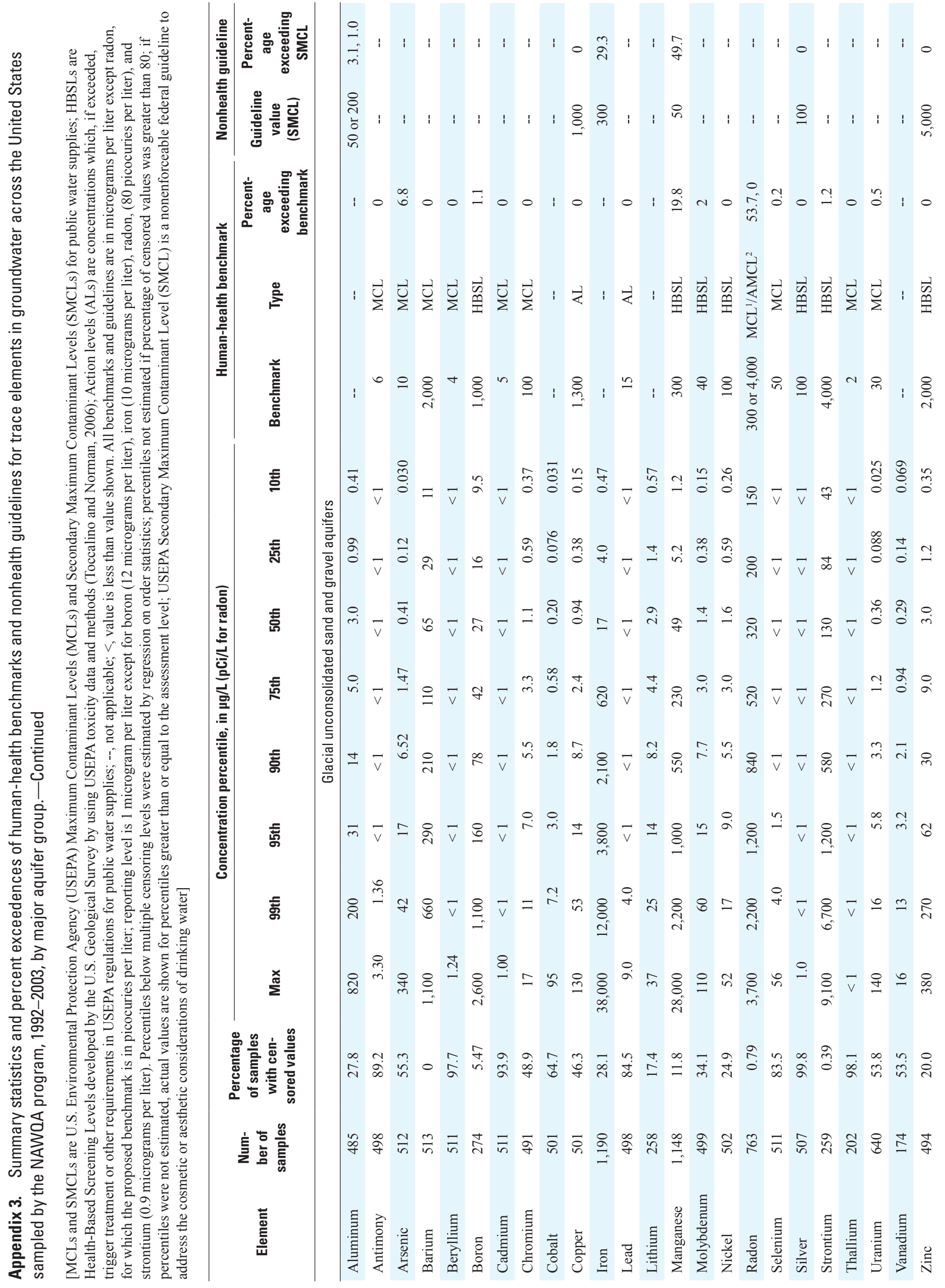




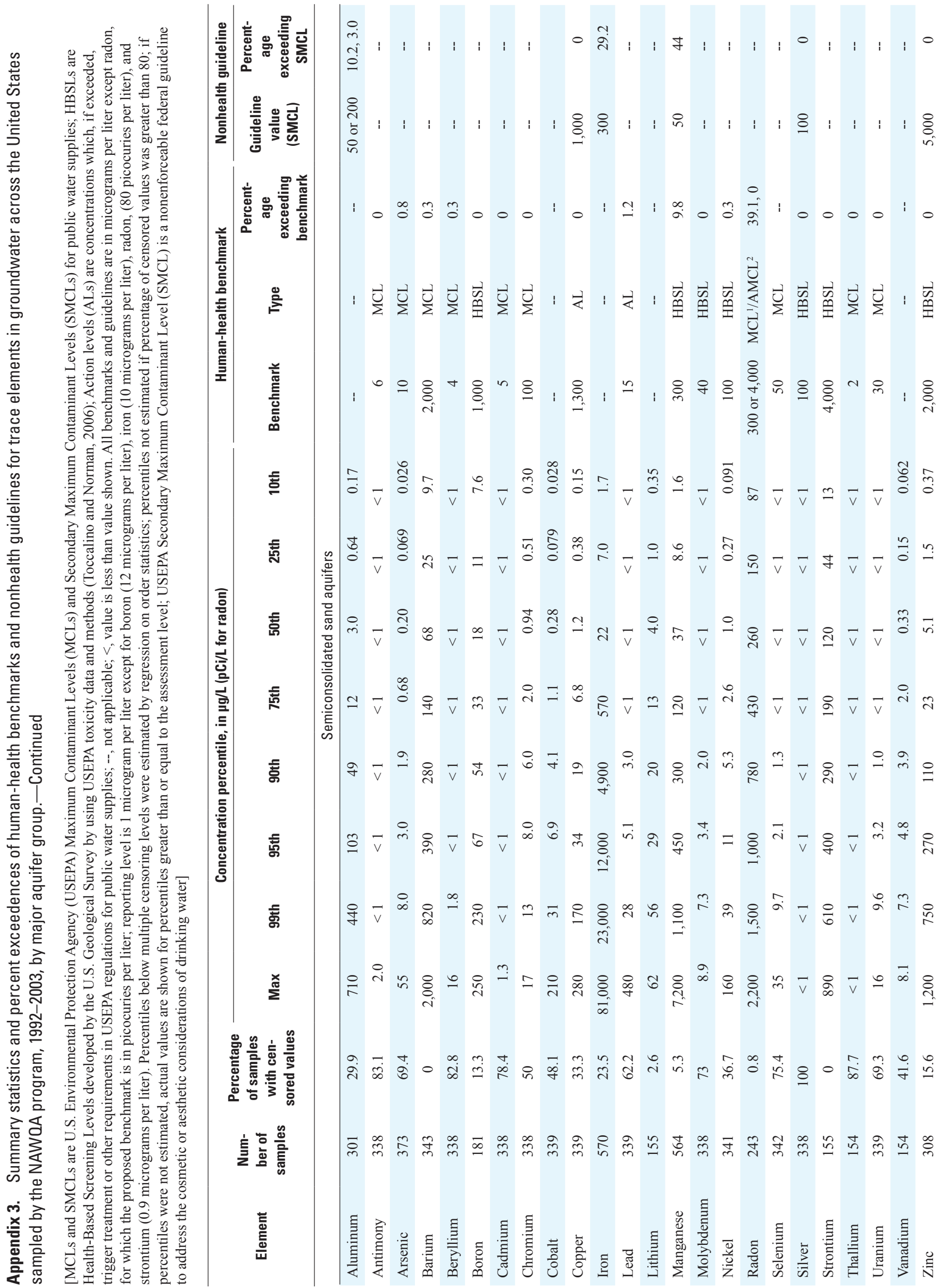




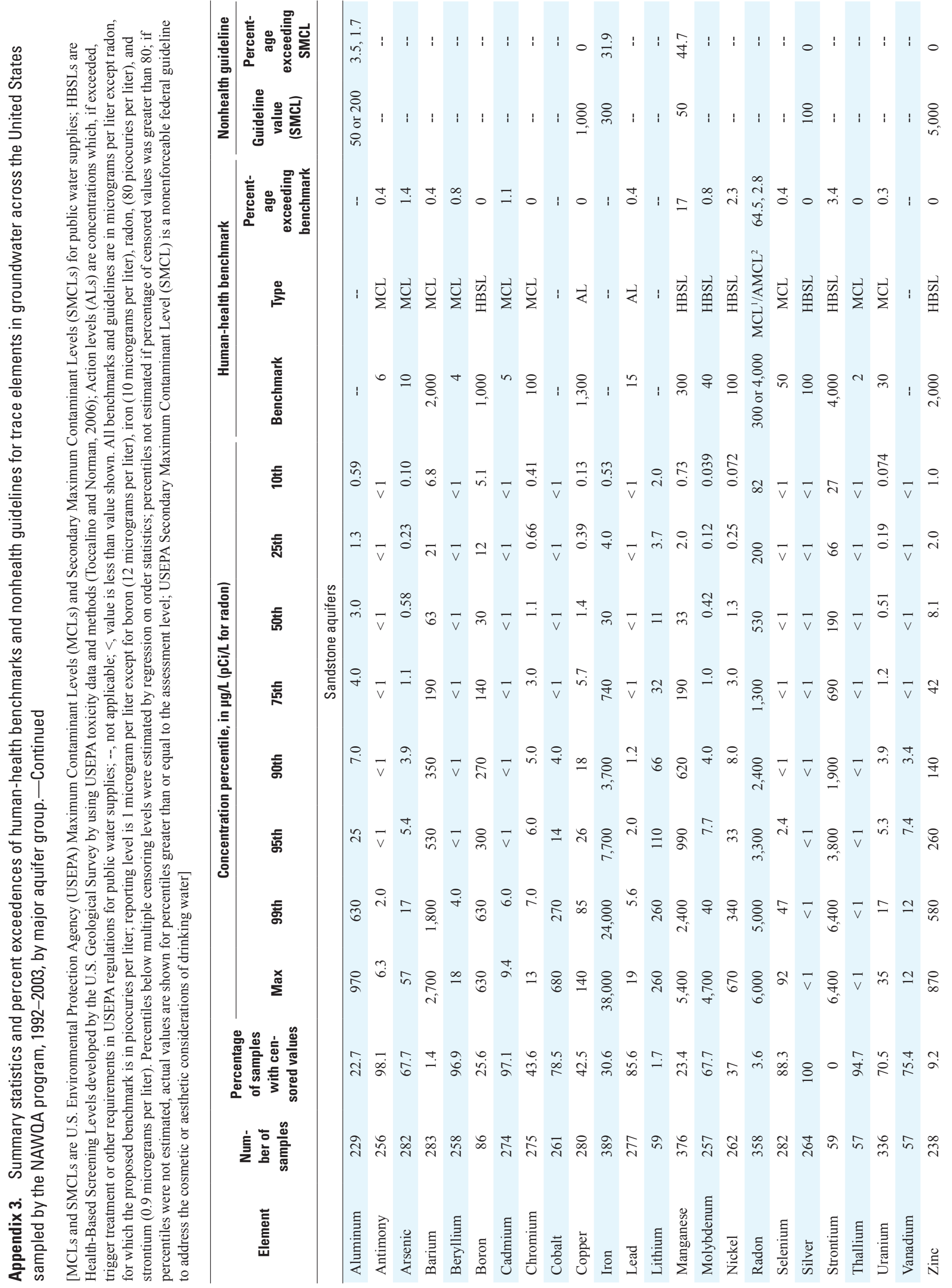




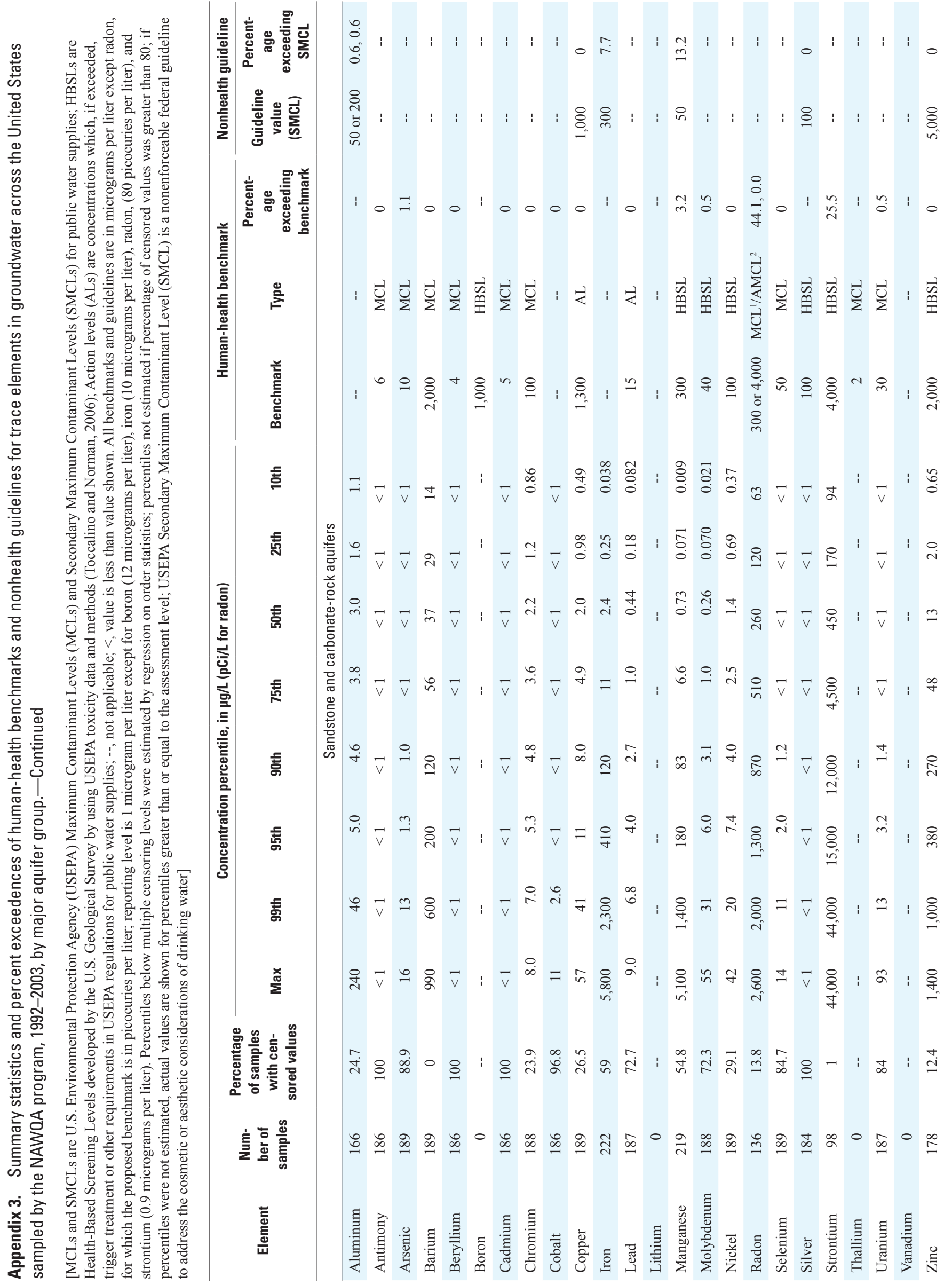




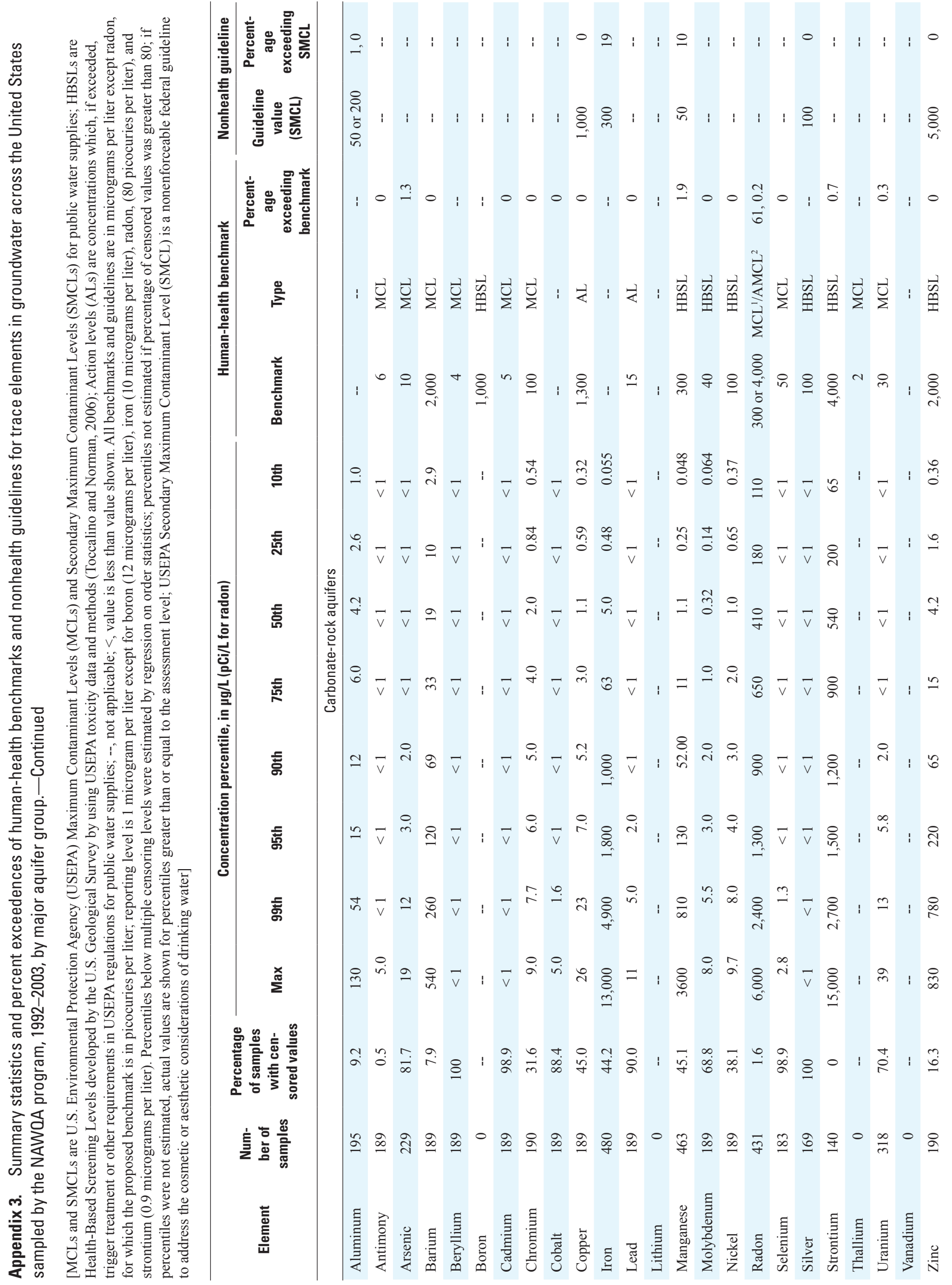




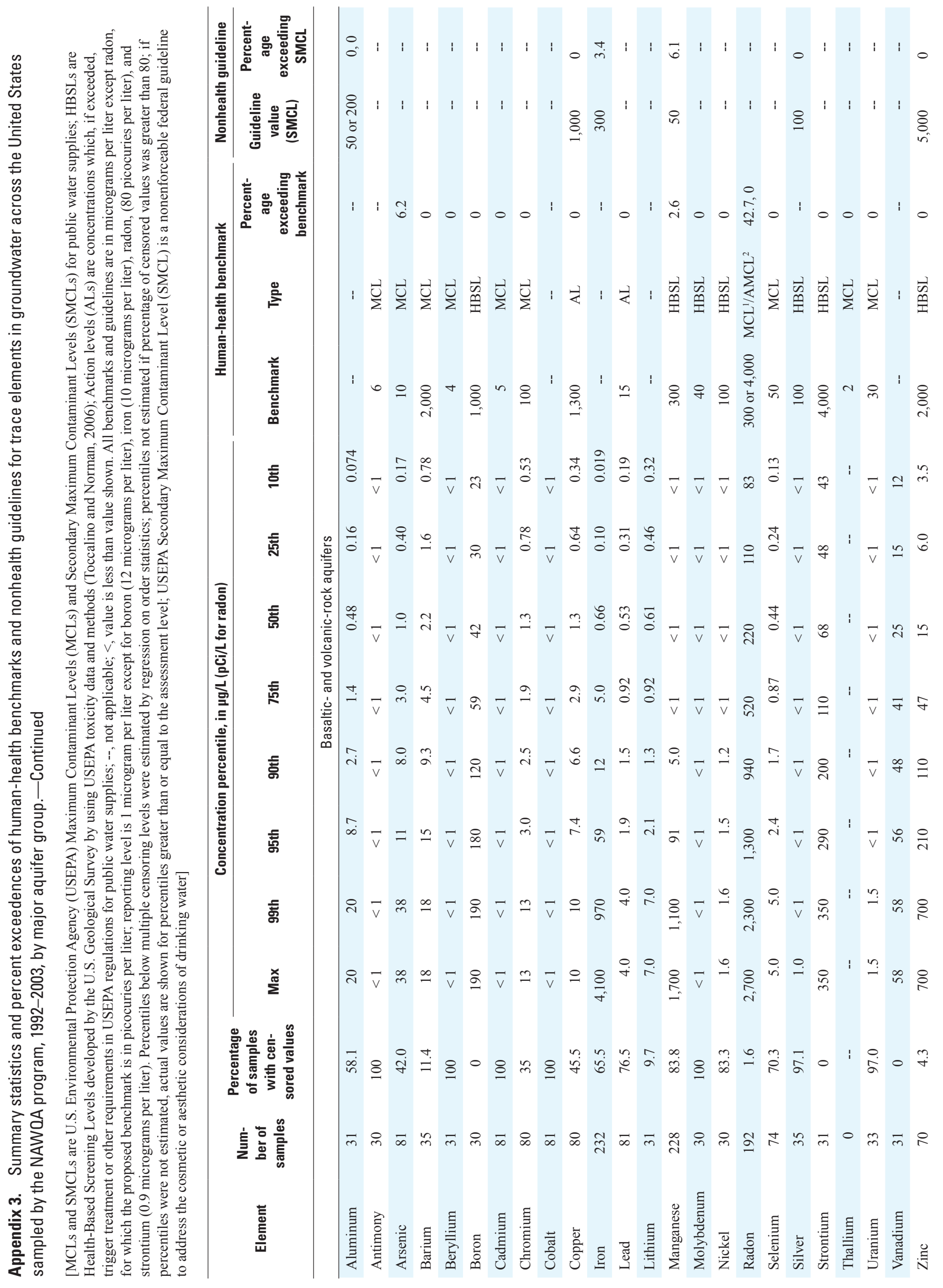




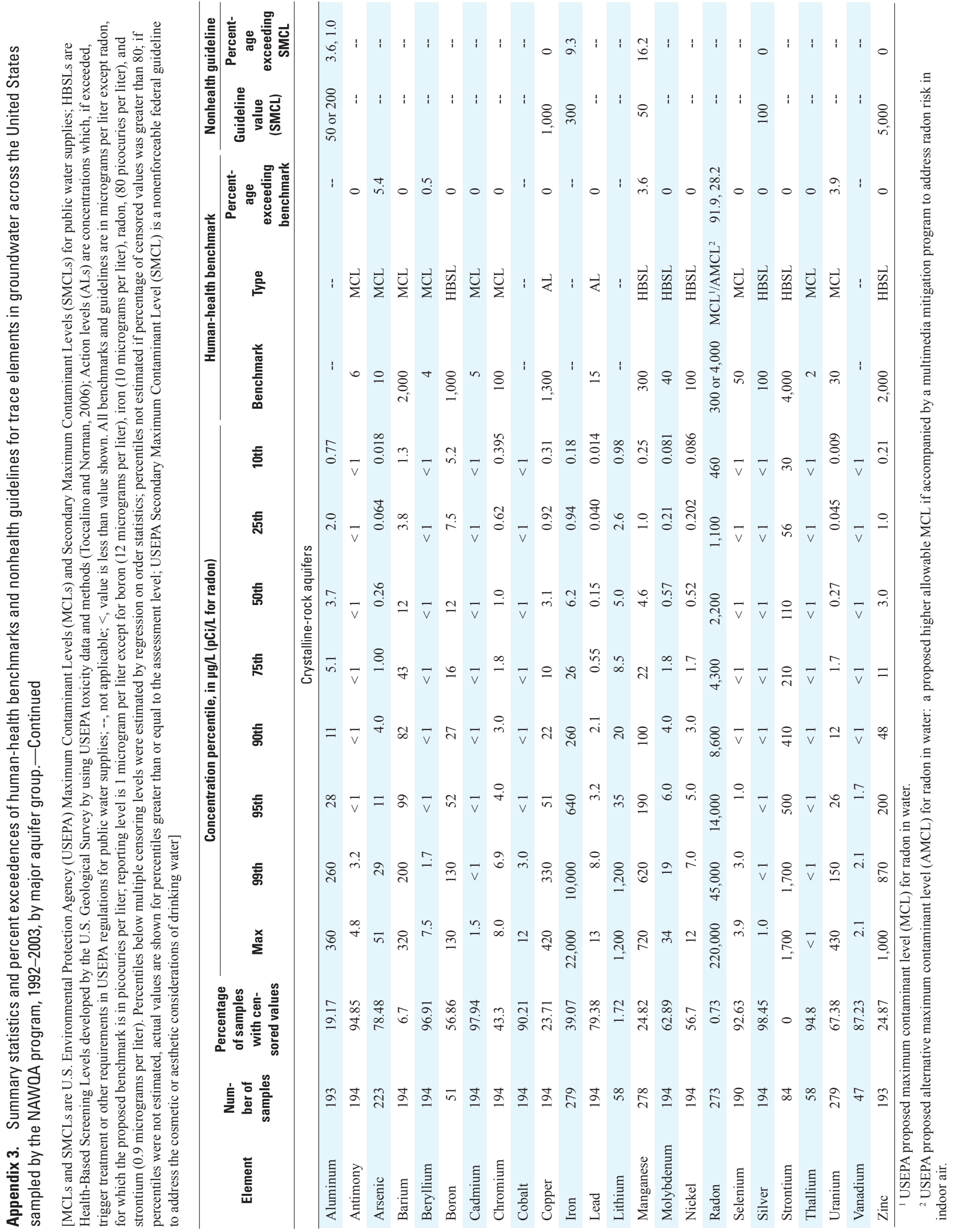


Appendix 4. Summary of the percent exceedences of human-health benchmarks and nonhealth guidelines for trace elements in groundwater across the United States sampled by the NAWQA Program, 1992-2003, by pH, redox state, and major aquifer group.

[Elements for which at least 1 percent of samples exceeded guidelines are shown with blue shading; the total number of these elements is shown at the bottom of the table; low $\mathrm{pH}$ is less than 7, whereas high $\mathrm{pH}$ is greater than or equal to $7 ; \mathrm{N}$, number of samples; $\%$, percentage; --, no data; $\geq$, greater than or equal to; benchmark or guidelines are in micrograms per liter for all elements except radon, for which the proposed benchmark is in picocuries per liter]

\begin{tabular}{|c|c|c|c|c|c|c|c|c|c|c|c|c|c|}
\hline \multirow{3}{*}{ Element } & \multirow{3}{*}{$\begin{array}{c}\text { Bench- } \\
\text { mark or } \\
\text { guideline }\end{array}$} & \multicolumn{6}{|c|}{ Low pH } & \multicolumn{6}{|c|}{ High pH } \\
\hline & & \multicolumn{2}{|c|}{ Oxic } & \multicolumn{2}{|c|}{ Mixed } & \multicolumn{2}{|c|}{ Anoxic } & \multicolumn{2}{|c|}{ Oxic } & \multicolumn{2}{|c|}{ Mixed } & \multicolumn{2}{|c|}{ Anoxic } \\
\hline & & $\mathbf{N}$ & $\%$ & $\mathbf{N}$ & $\%$ & $\mathbf{N}$ & $\%$ & $\mathbf{N}$ & $\%$ & $\mathbf{N}$ & $\%$ & $\mathbf{N}$ & $\%$ \\
\hline Aluminum & 200 & 116 & 0.86 & 45 & 6.7 & 57 & 11 & 710 & 0.28 & 125 & 0.0 & 143 & 0.0 \\
\hline Antimony & 6 & 133 & 0.0 & 43 & 0.0 & 55 & 0.0 & 787 & 0.0 & 123 & 0.0 & 145 & 0.0 \\
\hline Barium & 2,000 & 141 & 0.0 & 51 & 0.0 & 57 & 0.0 & 802 & 0.0 & 138 & 0.0 & 152 & 0.66 \\
\hline Beryllium & 4 & 133 & 0.0 & 43 & 0.0 & 55 & 0.0 & 787 & 0.0 & 123 & 0.0 & 145 & 0.0 \\
\hline Boron & 1,000 & 59 & 3.4 & 17 & 18 & 12 & 8.3 & 352 & 1.1 & 63 & 7.9 & 42 & 7.1 \\
\hline Cadmium & 5 & 133 & 0.75 & 43 & 0.0 & 55 & 0.0 & 787 & 0.25 & 123 & 0.81 & 146 & 0.68 \\
\hline Chromium & 100 & 137 & 0.0 & 49 & 2.0 & 55 & 0.0 & 777 & 0.0 & 133 & 0.0 & 150 & 0.0 \\
\hline Manganese & 300 & 199 & 0.0 & 73 & 32 & 67 & 42 & 968 & 0.0 & 149 & 36 & 162 & 54 \\
\hline Molybdenum & 40 & 140 & 1.4 & 50 & 4.0 & 56 & 0.0 & 799 & 1.3 & 138 & 8.0 & 151 & 2.0 \\
\hline Nickel & 100 & 141 & 0.0 & 50 & 0.0 & 56 & 0.0 & 798 & 0.0 & 138 & 0.0 & 151 & 0.0 \\
\hline Radon & 300 & 186 & 82 & 49 & 84 & 46 & 57 & 883 & 81 & 112 & 73 & 141 & 54 \\
\hline Selenium & 50 & 140 & 0.0 & 49 & 0.0 & 57 & 0.0 & 800 & 0.38 & 137 & 0.73 & 152 & 0.0 \\
\hline Silver & 100 & 129 & 0.0 & 39 & 0.0 & 53 & 0.0 & 780 & 0.0 & 122 & 0.0 & 142 & 0.0 \\
\hline Strontium & 4,000 & 54 & 5.6 & 19 & 16 & 25 & 4.0 & 309 & 3.9 & 40 & 13 & 28 & 0.0 \\
\hline Thallium & 2 & 41 & 0.0 & 7 & 0.0 & 5 & 0.0 & 252 & 0.0 & 34 & 0.0 & 25 & 0.0 \\
\hline
\end{tabular}


Appendix 4. Summary of the percent exceedences of human-health benchmarks and nonhealth guidelines for trace elements in groundwater across the United States sampled by the NAWOA Program, 1992-2003, by pH, redox state, and major aquifer group.

-Continued

[Elements for which at least 1 percent of samples exceeded guidelines are shown with blue shading; the total number of these elements is shown at the bottom of the table; low $\mathrm{pH}$ is less than 7 , whereas high $\mathrm{pH}$ is greater than or equal to $7 ; \mathrm{N}$, number of samples; \%, percentage; --, no data; $\geq$, greater than or equal to; benchmark or guidelines are in micrograms per liter for all elements except radon, for which the proposed benchmark is in picocuries per liter]

\begin{tabular}{|c|c|c|c|c|c|c|c|c|c|c|c|c|c|}
\hline \multirow{3}{*}{ Element } & \multirow{3}{*}{$\begin{array}{c}\text { Bench- } \\
\text { mark or } \\
\text { guideline }\end{array}$} & \multicolumn{6}{|c|}{ Low pH } & \multicolumn{6}{|c|}{ High pH } \\
\hline & & \multicolumn{2}{|c|}{ Oxic } & \multicolumn{2}{|c|}{ Mixed } & \multicolumn{2}{|c|}{ Anoxic } & \multicolumn{2}{|c|}{ Oxic } & \multicolumn{2}{|c|}{ Mixed } & \multicolumn{2}{|c|}{ Anoxic } \\
\hline & & $\mathbf{N}$ & $\%$ & $\mathbf{N}$ & $\%$ & $\mathbf{N}$ & $\%$ & $\mathbf{N}$ & $\%$ & $\mathbf{N}$ & $\%$ & $\mathbf{N}$ & $\%$ \\
\hline Aluminum & 200 & 99 & 0.0 & 78 & 5.1 & 42 & 2.4 & 85 & 0.0 & 73 & 0.0 & 94 & 0.0 \\
\hline Antimony & 6 & 104 & 0.0 & 80 & 0.0 & 41 & 0.0 & 89 & 0.0 & 75 & 0.0 & 94 & 0.0 \\
\hline Barium & 2,000 & 104 & 0.0 & 82 & 0.0 & 41 & 0.0 & 94 & 0.0 & 77 & 0.0 & 99 & 0.0 \\
\hline Beryllium & 4 & 104 & 0.0 & 81 & 0.0 & 41 & 0.0 & 93 & 0.0 & 77 & 0.0 & 99 & 0.0 \\
\hline Boron & 1,000 & 75 & 0.0 & 46 & 0.0 & 25 & 0.0 & 45 & 0.0 & 37 & 2.7 & 35 & 2.9 \\
\hline Cadmium & 5 & 104 & 0.0 & 81 & 0.0 & 41 & 0.0 & 93 & 0.0 & 77 & 0.0 & 99 & 0.0 \\
\hline Chromium & 100 & 100 & 0.0 & 81 & 0.0 & 40 & 0.0 & 88 & 0.0 & 75 & 0.0 & 92 & 0.0 \\
\hline Manganese & 300 & 206 & 0.0 & 168 & 37 & 88 & 44 & 238 & 0.0 & 189 & 32 & 220 & 26 \\
\hline Molybdenum & 40 & 104 & 0.0 & 80 & 0.0 & 41 & 0.0 & 90 & 3.3 & 75 & 5.3 & 94 & 1.1 \\
\hline Nickel & 100 & 104 & 0.0 & 81 & 0.0 & 42 & 0.0 & 90 & 0.0 & 75 & 0.0 & 94 & 0.0 \\
\hline Radon & 300 & 159 & 81 & 102 & 62 & 65 & 40 & 154 & 68 & 84 & 36 & 173 & 24 \\
\hline Selenium & 50 & 103 & 0.0 & 81 & 0.0 & 42 & 0.0 & 95 & 1.1 & 76 & 0.0 & 99 & 0.0 \\
\hline Silver & 100 & 103 & 0.0 & 81 & 0.0 & 39 & 0.0 & 92 & 0.0 & 77 & 0.0 & 99 & 0.0 \\
\hline Strontium & 4,000 & 73 & 0.0 & 46 & 2.2 & 22 & 0.0 & 46 & 2.2 & 33 & 0.0 & 30 & 3.3 \\
\hline Thallium & 2 & 58 & 0.0 & 42 & 0.0 & 10 & 0.0 & 36 & 0.0 & 26 & 0.0 & 22 & 0.0 \\
\hline
\end{tabular}


Appendix 4. Summary of the percent exceedences of human-health benchmarks and nonhealth guidelines for trace elements in groundwater across the United States sampled by the NAWQA Program, 1992-2003, by pH, redox state, and major aquifer group.

\section{-Continued}

[Elements for which at least 1 percent of samples exceeded guidelines are shown with blue shading; the total number of these elements is shown at the bottom of the table; low $\mathrm{pH}$ is less than 7 , whereas high $\mathrm{pH}$ is greater than or equal to $7 ; \mathrm{N}$, number of samples; \%, percentage; --, no data; $\geq$, greater than or equal to; benchmark or guidelines are in micrograms per liter for all elements except radon, for which the proposed benchmark is in picocuries per liter]

\begin{tabular}{|c|c|c|c|c|c|c|c|c|c|c|c|c|c|}
\hline \multirow{3}{*}{ Element } & \multirow{3}{*}{$\begin{array}{c}\text { Bench- } \\
\text { mark or } \\
\text { guideline }\end{array}$} & \multicolumn{6}{|c|}{ Low pH } & \multicolumn{6}{|c|}{ High pH } \\
\hline & & \multicolumn{2}{|c|}{ Oxic } & \multicolumn{2}{|c|}{ Mixed } & \multicolumn{2}{|c|}{ Anoxic } & \multicolumn{2}{|c|}{ Oxic } & \multicolumn{2}{|c|}{ Mixed } & \multicolumn{2}{|c|}{ Anoxic } \\
\hline & & $\mathbf{N}$ & $\%$ & $\mathbf{N}$ & $\%$ & $\mathbf{N}$ & $\%$ & $\mathbf{N}$ & $\%$ & $\mathbf{N}$ & $\%$ & $\mathbf{N}$ & $\%$ \\
\hline \multicolumn{14}{|c|}{ Semiconsolidated sand aquifers (SCS) } \\
\hline Aluminum & 200 & 100 & 1.0 & 68 & 10 & 44 & 2.3 & 7 & 0.0 & 14 & 0.0 & 18 & 0.0 \\
\hline Antimony & 6 & 104 & 0.0 & 70 & 0.0 & 46 & 0.0 & 18 & 0.0 & 14 & 0.0 & 25 & 0.0 \\
\hline Arsenic & 10 & 125 & 0.0 & 74 & 1.4 & 50 & 4.0 & 18 & 0.0 & 16 & 0.0 & 27 & 0.0 \\
\hline Barium & 2,000 & 104 & 1.0 & 70 & 0.0 & 46 & 0.0 & 18 & 0.0 & 16 & 0.0 & 26 & 0.0 \\
\hline Beryllium & 4 & 104 & 0.0 & 70 & 1.4 & 46 & 0.0 & 18 & 0.0 & 14 & 0.0 & 25 & 0.0 \\
\hline Boron & 1,000 & 67 & 0.0 & 41 & 0.0 & 25 & 0.0 & 2 & 0.0 & 9 & 0.0 & 7 & 0.0 \\
\hline Cadmium & 5 & 104 & 0.0 & 70 & 0.0 & 46 & 0.0 & 18 & 0.0 & 14 & 0.0 & 25 & 0.0 \\
\hline Chromium & 100 & 103 & 0.0 & 69 & 0.0 & 46 & 0.0 & 18 & 0.0 & 16 & 0.0 & 26 & 0.0 \\
\hline Copper & 1,300 & 104 & 0.0 & 70 & 0.0 & 46 & 0.0 & 18 & 0.0 & 15 & 0.0 & 25 & 0.0 \\
\hline Iron & 300 & 195 & 0.0 & 142 & 37 & 73 & 79 & 28 & 0.0 & 19 & 63 & 37 & 62 \\
\hline Lead & 15 & 104 & 2.9 & 70 & 1.4 & 46 & 0.0 & 18 & 0.0 & 15 & 0.0 & 25 & 0.0 \\
\hline Manganese & 300 & 189 & 0.0 & 142 & 13 & 73 & 25 & 28 & 0.0 & 19 & 26 & 37 & 11 \\
\hline Molybdenum & 40 & 104 & 0.0 & 70 & 0.0 & 46 & 0.0 & 18 & 0.0 & 14 & 0.0 & 25 & 0.0 \\
\hline Nickel & 100 & 104 & 0.0 & 70 & 1.4 & 46 & 0.0 & 18 & 0.0 & 15 & 0.0 & 26 & 0.0 \\
\hline Radon & 300 & 80 & 36 & 38 & 47 & 37 & 32 & 15 & 6.7 & 10 & 40 & 15 & 27 \\
\hline Selenium & 50 & 104 & 0.0 & 70 & 0.0 & 46 & 0.0 & 18 & 0.0 & 16 & 0.0 & 26 & 0.0 \\
\hline Silver & 100 & 104 & 0.0 & 70 & 0.0 & 46 & 0.0 & 18 & 0.0 & 14 & 0.0 & 25 & 0.0 \\
\hline Strontium & 4,000 & 53 & 0.0 & 33 & 0.0 & 22 & 0.0 & 2 & 0.0 & 9 & 0.0 & 6 & 0.0 \\
\hline Thallium & 2 & 53 & 0.0 & 33 & 0.0 & 22 & 0.0 & 2 & 0.0 & 9 & 0.0 & 6 & 0.0 \\
\hline Uranium & 30 & 104 & 0.0 & 70 & 0.0 & 46 & 0.0 & 18 & 0.0 & 15 & 0.0 & 25 & 0.0 \\
\hline Zinc & 2,000 & 98 & 0.0 & 67 & 0.0 & 45 & 0.0 & 9 & 0.0 & 16 & 0.0 & 20 & 0.0 \\
\hline $\begin{array}{l}\text { Number of eles } \\
\quad \geq 1 \% \text { exceec }\end{array}$ & $\begin{array}{l}\text { nts with } \\
\text { ice }\end{array}$ & & 4 & & 8 & & 5 & & 1 & & 3 & & 3 \\
\hline
\end{tabular}


Appendix 4. Summary of the percent exceedences of human-health benchmarks and nonhealth guidelines for trace elements in groundwater across the United States sampled by the NAWOA Program, 1992-2003, by pH, redox state, and major aquifer group.

-Continued

[Elements for which at least 1 percent of samples exceeded guidelines are shown with blue shading; the total number of these elements is shown at the bottom of the table; low $\mathrm{pH}$ is less than 7 , whereas high $\mathrm{pH}$ is greater than or equal to $7 ; \mathrm{N}$, number of samples; \%, percentage; --, no data; $\geq$, greater than or equal to; benchmark or guidelines are in micrograms per liter for all elements except radon, for which the proposed benchmark is in picocuries per liter]

\begin{tabular}{|c|c|c|c|c|c|c|c|c|c|c|c|c|c|}
\hline \multirow{3}{*}{ Element } & \multirow{3}{*}{$\begin{array}{l}\text { Bench- } \\
\text { mark or } \\
\text { guideline }\end{array}$} & \multicolumn{6}{|c|}{ Low pH } & \multicolumn{6}{|c|}{ High pH } \\
\hline & & \multicolumn{2}{|c|}{ Oxic } & \multicolumn{2}{|c|}{ Mixed } & \multicolumn{2}{|c|}{ Anoxic } & \multicolumn{2}{|c|}{ Oxic } & \multicolumn{2}{|c|}{ Mixed } & \multicolumn{2}{|c|}{ Anoxic } \\
\hline & & $\mathbf{N}$ & $\%$ & $\mathbf{N}$ & $\%$ & $\mathbf{N}$ & $\%$ & $\mathbf{N}$ & $\%$ & $\mathbf{N}$ & $\%$ & $\mathbf{N}$ & $\%$ \\
\hline \multicolumn{14}{|c|}{ Sandstone aquifers (SAN) } \\
\hline Aluminum & 200 & 20 & 0.0 & 27 & 11 & 31 & 0.0 & 78 & 0.0 & 14 & 0.0 & 50 & 0.0 \\
\hline Antimony & 6 & 33 & 0.0 & 30 & 0.0 & 33 & 0.0 & 84 & 1.2 & 16 & 0.0 & 49 & 0.0 \\
\hline Arsenic & 10 & 35 & 0.0 & 31 & 0.0 & 34 & 0.0 & 99 & 4.0 & 16 & 0.0 & 51 & 0.0 \\
\hline Barium & 2,000 & 35 & 0.0 & 31 & 0.0 & 34 & 0.0 & 100 & 0.0 & 16 & 0.0 & 51 & 2.0 \\
\hline Beryllium & 4 & 33 & 0.0 & 30 & 3.3 & 33 & 0.0 & 84 & 0.0 & 16 & 0.0 & 49 & 0.0 \\
\hline Boron & 1,000 & 19 & 0.0 & -- & -- & -- & -- & 46 & 0.0 & 4 & 0.0 & 13 & 0.0 \\
\hline Cadmium & 5 & 35 & 0.0 & 30 & 3.3 & 33 & 0.0 & 99 & 1.0 & 16 & 0.0 & 49 & 0.0 \\
\hline Chromium & 100 & 33 & 0.0 & 30 & 0.0 & 33 & 0.0 & 99 & 0.0 & 16 & 0.0 & 51 & 0.0 \\
\hline Copper & 1,300 & 35 & 0.0 & 31 & 0.0 & 34 & 0.0 & 100 & 0.0 & 16 & 0.0 & 49 & 0.0 \\
\hline Iron & 300 & 40 & 0.0 & 40 & 60 & 50 & 90 & 143 & 0.0 & 26 & 42 & 72 & 50 \\
\hline Lead & 15 & 35 & 0.0 & 31 & 0.0 & 34 & 2.9 & 99 & 0.0 & 16 & 0.0 & 49 & 0.0 \\
\hline Manganese & 300 & 39 & 0.0 & 37 & 54 & 49 & 53 & 135 & 0.0 & 27 & 15 & 74 & 11 \\
\hline Molybdenum & 40 & 33 & 0.0 & 30 & 0.0 & 33 & 0.0 & 85 & 1.2 & 16 & 0.0 & 49 & 2.0 \\
\hline Nickel & 100 & 33 & 0.0 & 31 & 3.2 & 34 & 2.9 & 84 & 0.0 & 16 & 0.0 & 49 & 0.0 \\
\hline Radon & 300 & 35 & 86 & 34 & 44 & 46 & 24 & 131 & 86 & 26 & 62 & 71 & 55 \\
\hline Selenium & 50 & 35 & 0.0 & 31 & 0.0 & 34 & 0.0 & 100 & 1.0 & 16 & 0.0 & 51 & 0.0 \\
\hline Silver & 100 & 35 & 0.0 & 29 & 0.0 & 32 & 0.0 & 97 & 0.0 & 15 & 0.0 & 45 & 0.0 \\
\hline Strontium & 4,000 & 14 & 0.0 & -- & -- & -- & -- & 28 & 0.0 & 4 & 25 & 10 & 0.0 \\
\hline Thallium & 2 & 14 & 0.0 & -- & -- & -- & -- & 27 & 0.0 & 4 & 0.0 & 10 & 0.0 \\
\hline Uranium & 30 & 36 & 0.0 & 34 & 2.9 & 43 & 0.0 & 117 & 0.0 & 24 & 0.0 & 62 & 0.0 \\
\hline Zinc & 2,000 & 22 & 0.0 & 27 & 0.0 & 32 & 0.0 & 79 & 0.0 & 15 & 0.0 & 50 & 0.0 \\
\hline $\begin{array}{l}\text { Number of eler } \\
\quad \geq 1 \% \text { exceec }\end{array}$ & $\begin{array}{l}\text { nts with } \\
\text { ce }\end{array}$ & & 1 & & 8 & & 5 & & 6 & & 4 & & 5 \\
\hline
\end{tabular}


Appendix 4. Summary of the percent exceedences of human-health benchmarks and nonhealth guidelines for trace elements in groundwater across the United States sampled by the NAWQA Program, 1992-2003, by pH, redox state, and major aquifer group.

\section{-Continued}

[Elements for which at least 1 percent of samples exceeded guidelines are shown with blue shading; the total number of these elements is shown at the bottom of the table; low $\mathrm{pH}$ is less than 7 , whereas high $\mathrm{pH}$ is greater than or equal to $7 ; \mathrm{N}$, number of samples; $\%$, percentage; --, no data; $\geq$, greater than or equal to; benchmark or guidelines are in micrograms per liter for all elements except radon, for which the proposed benchmark is in picocuries per liter]

\begin{tabular}{|c|c|c|c|c|c|c|c|c|c|c|c|c|c|}
\hline \multirow{3}{*}{ Element } & \multirow{3}{*}{$\begin{array}{c}\text { Bench- } \\
\text { mark or } \\
\text { guideline }\end{array}$} & \multicolumn{6}{|c|}{ Low pH } & \multicolumn{6}{|c|}{ High pH } \\
\hline & & \multicolumn{2}{|c|}{ Oxic } & \multicolumn{2}{|c|}{ Mixed } & \multicolumn{2}{|c|}{ Anoxic } & \multicolumn{2}{|c|}{ Oxic } & \multicolumn{2}{|c|}{ Mixed } & \multicolumn{2}{|c|}{ Anoxic } \\
\hline & & $\mathbf{N}$ & $\%$ & $\mathbf{N}$ & $\%$ & $\mathbf{N}$ & $\%$ & $\mathbf{N}$ & $\%$ & $\mathbf{N}$ & $\%$ & $\mathbf{N}$ & $\%$ \\
\hline \multicolumn{14}{|c|}{ Sandstone and carbonate-rock aquifers (SCR) } \\
\hline Aluminum & 200 & 80 & 1.3 & 8 & 0.0 & 5 & 0.0 & 64 & 0.0 & 2 & 0.0 & 6 & 0.0 \\
\hline Antimony & 6 & 80 & 0.0 & 8 & 0.0 & 4 & 0.0 & 73 & 0.0 & 3 & 0.0 & 7 & 0.0 \\
\hline Arsenic & 10 & 81 & 0.0 & 8 & 0.0 & 6 & 0.0 & 73 & 2.7 & 3 & 0.0 & 7 & 0.0 \\
\hline Barium & 2,000 & 81 & 0.0 & 8 & 0.0 & 6 & 0.0 & 73 & 0.0 & 3 & 0.0 & 7 & 0.0 \\
\hline Beryllium & 4 & 80 & 0.0 & 8 & 0.0 & 4 & 0.0 & 73 & 0.0 & 3 & 0.0 & 7 & 0.0 \\
\hline Boron & 1,000 & -- & -- & -- & -- & -- & -- & -- & -- & -- & -- & -- & -- \\
\hline Cadmium & 5 & 80 & 0.0 & 8 & 0.0 & 4 & 0.0 & 73 & 0.0 & 3 & 0.0 & 7 & 0.0 \\
\hline Chromium & 100 & 80 & 0.0 & 8 & 0.0 & 6 & 0.0 & 73 & 0.0 & 3 & 0.0 & 7 & 0.0 \\
\hline Copper & 1,300 & 81 & 0.0 & 8 & 0.0 & 6 & 0.0 & 73 & 0.0 & 3 & 0.0 & 7 & 0.0 \\
\hline Iron & 300 & 91 & 0.0 & 20 & 30 & 7 & 57 & 76 & 0.0 & 7 & 0.0 & 8 & 75 \\
\hline Lead & 15 & 80 & 0.0 & 8 & 0.0 & 5 & 0.0 & 73 & 0.0 & 3 & 0.0 & 7 & 0.0 \\
\hline Manganese & 300 & 89 & 0.0 & 20 & 25 & 7 & 0.0 & 75 & 0.0 & 7 & 29 & 8 & 0.0 \\
\hline Molybdenum & 40 & 81 & 0.0 & 8 & 0.0 & 5 & 0.0 & 73 & 1.4 & 3 & 0.0 & 7 & 0.0 \\
\hline Nickel & 100 & 81 & 0.0 & 8 & 0.0 & 6 & 0.0 & 73 & 0.0 & 3 & 0.0 & 7 & 0.0 \\
\hline Radon & 300 & 53 & 57 & 7 & 57 & 6 & 33 & 62 & 34 & 2 & 0.0 & 5 & 60 \\
\hline Selenium & 50 & 81 & 0.0 & 8 & 0.0 & 6 & 0.0 & 73 & 0.0 & 3 & 0.0 & 7 & 0.0 \\
\hline Silver & 100 & 80 & 0.0 & 8 & 0.0 & 4 & 0.0 & 72 & 0.0 & 2 & 0.0 & 7 & 0.0 \\
\hline Strontium & 4,000 & 46 & 8.7 & 1 & 0.0 & 4 & 100 & 40 & 30 & 1 & 0.0 & 5 & 80 \\
\hline Thallium & 2 & -- & -- & -- & -- & -- & -- & -- & -- & -- & -- & -- & -- \\
\hline Uranium & 30 & 80 & 0.0 & 8 & 0.0 & 5 & 0.0 & 73 & 0.0 & 3 & 0.0 & 7 & 0.0 \\
\hline Zinc & 2,000 & 80 & 0.0 & 8 & 0.0 & 6 & 0.0 & 69 & 0.0 & 3 & 0.0 & 7 & 0.0 \\
\hline $\begin{array}{l}\text { Number of eler } \\
\quad \geq 1 \% \text { exceec }\end{array}$ & $\begin{array}{l}\text { nts with } \\
\text { ce }\end{array}$ & & 3 & & 3 & & 3 & & 4 & & 1 & & 3 \\
\hline
\end{tabular}


Appendix 4. Summary of the percent exceedences of human-health benchmarks and nonhealth guidelines for trace elements in groundwater across the United States sampled by the NAWOA Program, 1992-2003, by pH, redox state, and major aquifer group.

\section{-Continued}

[Elements for which at least 1 percent of samples exceeded guidelines are shown with blue shading; the total number of these elements is shown at the bottom of the table; low $\mathrm{pH}$ is less than 7 , whereas high $\mathrm{pH}$ is greater than or equal to $7 ; \mathrm{N}$, number of samples; \%, percentage; --, no data; $\geq$, greater than or equal to; benchmark or guidelines are in micrograms per liter for all elements except radon, for which the proposed benchmark is in picocuries per liter]

\begin{tabular}{|c|c|c|c|c|c|c|c|c|c|c|c|c|c|}
\hline \multirow{3}{*}{ Element } & \multirow{3}{*}{$\begin{array}{l}\text { Bench- } \\
\text { mark or } \\
\text { guideline }\end{array}$} & \multicolumn{6}{|c|}{ Low pH } & \multicolumn{6}{|c|}{ High pH } \\
\hline & & \multicolumn{2}{|c|}{ Oxic } & \multicolumn{2}{|c|}{ Mixed } & \multicolumn{2}{|c|}{ Anoxic } & \multicolumn{2}{|c|}{ Oxic } & \multicolumn{2}{|c|}{ Mixed } & \multicolumn{2}{|c|}{ Anoxic } \\
\hline & & $\mathbf{N}$ & $\%$ & $\mathbf{N}$ & $\%$ & $\mathbf{N}$ & $\%$ & $\mathbf{N}$ & $\%$ & $\mathbf{N}$ & $\%$ & $\mathbf{N}$ & $\%$ \\
\hline \multicolumn{14}{|c|}{ Carbonate-rock aquifers (CAR) } \\
\hline Aluminum & 200 & 21 & 0.0 & 12 & 0.0 & 37 & 0.0 & 103 & 0.0 & 1 & 0.0 & 18 & 0.0 \\
\hline Antimony & 6 & 21 & 0.0 & 11 & 0.0 & 37 & 0.0 & 98 & 0.0 & 1 & 0.0 & 18 & 0.0 \\
\hline Arsenic & 10 & 28 & 0.0 & 14 & 7.1 & 37 & 5.4 & 127 & 0.0 & 1 & 0.0 & 19 & 0.0 \\
\hline Barium & 2,000 & 21 & 0.0 & 11 & 0.0 & 37 & 0.0 & 98 & 0.0 & 1 & 0.0 & 18 & 0.0 \\
\hline Beryllium & 4 & 21 & 0.0 & 11 & 0.0 & 37 & 0.0 & 98 & 0.0 & 1 & 0.0 & 18 & 0.0 \\
\hline Boron & 1,000 & -- & -- & -- & -- & -- & -- & -- & -- & -- & -- & -- & -- \\
\hline Cadmium & 5 & 21 & 0.0 & 11 & 0.0 & 37 & 0.0 & 98 & 0.0 & 1 & 0.0 & 18 & 0.0 \\
\hline Chromium & 100 & 21 & 0.0 & 11 & 0.0 & 37 & 0.0 & 99 & 0.0 & 1 & 0.0 & 18 & 0.0 \\
\hline Copper & 1,300 & 21 & 0.0 & 11 & 0.0 & 37 & 0.0 & 98 & 0.0 & 1 & 0.0 & 18 & 0.0 \\
\hline Iron & 300 & 58 & 0.0 & 22 & 41 & 49 & 90 & 286 & 0.0 & 9 & 22 & 49 & 73 \\
\hline Lead & 15 & 21 & 0.0 & 11 & 0.0 & 37 & 0.0 & 98 & 0.0 & 1 & 0.0 & 18 & 0.0 \\
\hline Manganese & 300 & 52 & 0.0 & 22 & 14 & 49 & 6.1 & 276 & 0.0 & 9 & 0.0 & 48 & 6.3 \\
\hline Molybdenum & 40 & 21 & 0.0 & 11 & 0.0 & 37 & 0.0 & 98 & 0.0 & 1 & 0.0 & 18 & 0.0 \\
\hline Nickel & 100 & 21 & 0.0 & 11 & 0.0 & 37 & 0.0 & 98 & 0.0 & 1 & 0.0 & 18 & 0.0 \\
\hline Radon & 300 & 49 & 69 & 19 & 79 & 49 & 73 & 254 & 58 & 8 & 88 & 46 & 43 \\
\hline Selenium & 50 & 20 & 0.0 & 11 & 0.0 & 37 & 0.0 & 93 & 0.0 & 1 & 0.0 & 18 & 0.0 \\
\hline Silver & 100 & 20 & 0.0 & 11 & 0.0 & 30 & 0.0 & 90 & 0.0 & 1 & 0.0 & 14 & 0.0 \\
\hline Strontium & 4,000 & 8 & 0.0 & 7 & 0.0 & 33 & 0.0 & 77 & 1.3 & 5 & 0.0 & 9 & 0.0 \\
\hline Thallium & 2 & -- & -- & -- & -- & -- & -- & -- & -- & -- & -- & -- & -- \\
\hline Uranium & 30 & 23 & 0.0 & 11 & 0.0 & 38 & 0.0 & 213 & 0.47 & 6 & 0.0 & 23 & 0.0 \\
\hline Zinc & 2,000 & 21 & 0.0 & 11 & 0.0 & 37 & 0.0 & 99 & 0.0 & 1 & 0.0 & 18 & 0.0 \\
\hline $\begin{array}{l}\text { Number of ele } \\
\quad \geq 1 \% \text { exceec }\end{array}$ & $\begin{array}{l}\text { nts with } \\
\text { nce }\end{array}$ & & 1 & & 4 & & 4 & & 2 & & 2 & & 3 \\
\hline
\end{tabular}


Appendix 4. Summary of the percent exceedences of human-health benchmarks and nonhealth guidelines for trace elements in groundwater across the United States sampled by the NAWQA Program, 1992-2003, by pH, redox state, and major aquifer group.

\section{Continued}

[Elements for which at least 1 percent of samples exceeded guidelines are shown with blue shading; the total number of these elements is shown at the bottom of the table; low $\mathrm{pH}$ is less than 7, whereas high $\mathrm{pH}$ is greater than or equal to 7; $\mathrm{N}$, number of samples; \%, percentage; --, no data; $\geq$, greater than or equal to; benchmark or guidelines are in micrograms per liter for all elements except radon, for which the proposed benchmark is in picocuries per liter]

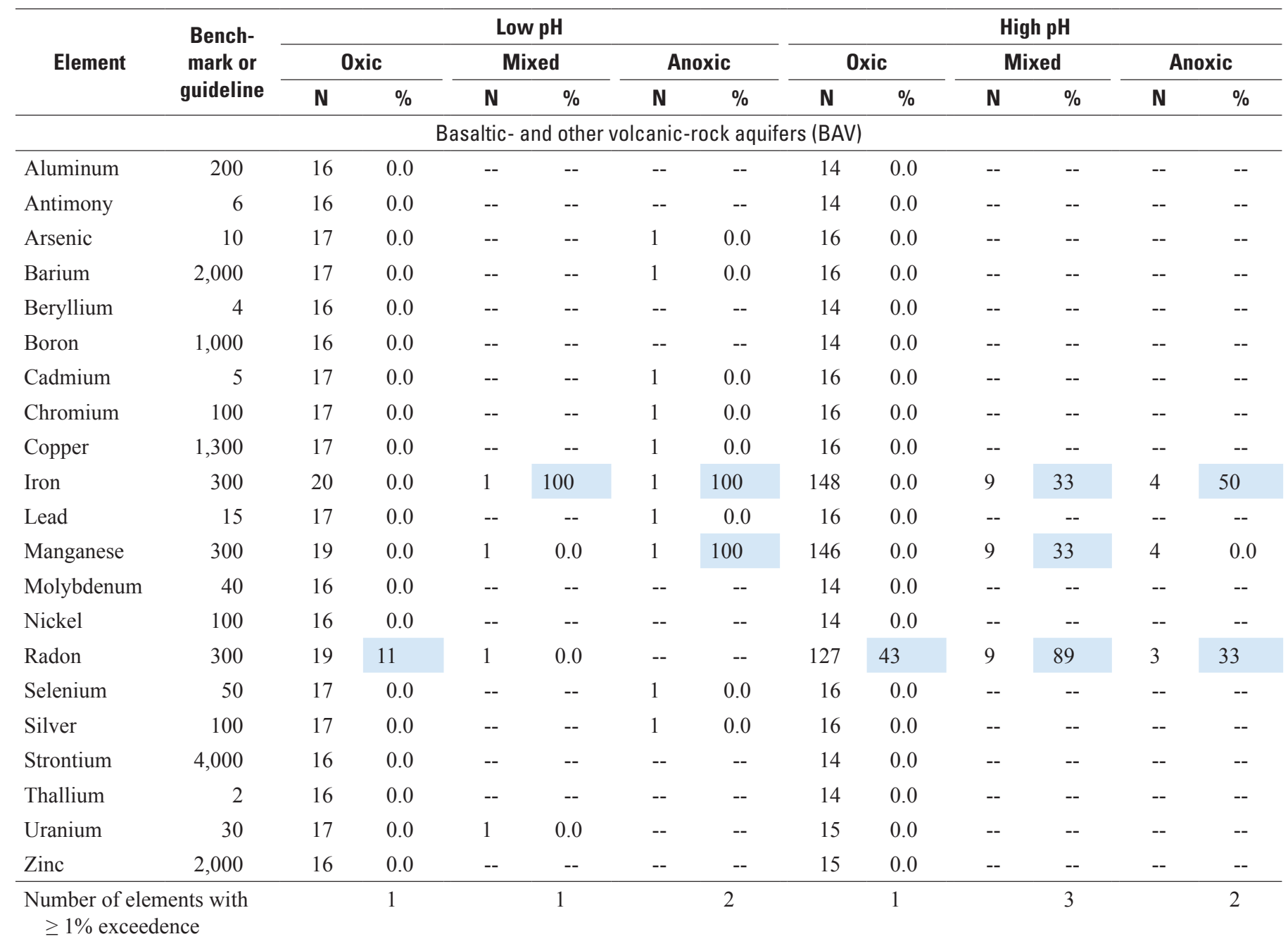


Appendix 4. Summary of the percent exceedences of human-health benchmarks and nonhealth guidelines for trace elements in groundwater across the United States sampled by the NAWQA Program, 1992-2003, by pH, redox state, and major aquifer group.

\section{-Continued}

[Elements for which at least 1 percent of samples exceeded guidelines are shown with blue shading; the total number of these elements is shown at the bottom of the table; low $\mathrm{pH}$ is less than 7, whereas high $\mathrm{pH}$ is greater than or equal to $7 ; \mathrm{N}$, number of samples; \%, percentage; --, no data; $\geq$, greater than or equal to; benchmark or guidelines are in micrograms per liter for all elements except radon, for which the proposed benchmark is in picocuries per liter]

\begin{tabular}{|c|c|c|c|c|c|c|c|c|c|c|c|c|c|}
\hline \multirow{3}{*}{ Element } & \multirow{3}{*}{$\begin{array}{l}\text { Bench- } \\
\text { mark or } \\
\text { guideline }\end{array}$} & \multicolumn{6}{|c|}{ Low pH } & \multicolumn{6}{|c|}{ High pH } \\
\hline & & \multicolumn{2}{|c|}{ Oxic } & \multicolumn{2}{|c|}{ Mixed } & \multicolumn{2}{|c|}{ Anoxic } & \multicolumn{2}{|c|}{ Oxic } & \multicolumn{2}{|c|}{ Mixed } & \multicolumn{2}{|c|}{ Anoxic } \\
\hline & & $\mathbf{N}$ & $\%$ & $\mathbf{N}$ & $\%$ & $\mathbf{N}$ & $\%$ & $\mathbf{N}$ & $\%$ & $\mathbf{N}$ & $\%$ & $\mathbf{N}$ & $\%$ \\
\hline \multicolumn{14}{|c|}{ Crystalline-rock aquifers (CRL) } \\
\hline Aluminum & 200 & 91 & 0.0 & 15 & 13 & 4 & 0.0 & 62 & 0.0 & 2 & 0.0 & 16 & 0.0 \\
\hline Antimony & 6 & 91 & 0.0 & 15 & 0.0 & 4 & 0.0 & 63 & 0.0 & 2 & 0.0 & 16 & 0.0 \\
\hline Arsenic & 10 & 102 & 0.0 & 16 & 0.0 & 4 & 0.0 & 76 & 11 & 3 & 0.0 & 19 & 16 \\
\hline Barium & 2,000 & 91 & 0.0 & 15 & 0.0 & 4 & 0.0 & 63 & 0.0 & 2 & 0.0 & 16 & 0.0 \\
\hline Beryllium & 4 & 91 & 0.0 & 15 & 6.7 & 4 & 0.0 & 63 & 0.0 & 2 & 0.0 & 16 & 0.0 \\
\hline Boron & 1,000 & 12 & 0.0 & 2 & 0.0 & -- & -- & 26 & 0.0 & -- & -- & 11 & 0.0 \\
\hline Cadmium & 5 & 91 & 0.0 & 15 & 0.0 & 4 & 0.0 & 63 & 0.0 & 2 & 0.0 & 16 & 0.0 \\
\hline Chromium & 100 & 91 & 0.0 & 15 & 0.0 & 4 & 0.0 & 63 & 0.0 & 2 & 0.0 & 16 & 0.0 \\
\hline Copper & 1,300 & 91 & 0.0 & 15 & 0.0 & 4 & 0.0 & 63 & 0.0 & 2 & 0.0 & 16 & 0.0 \\
\hline Iron & 300 & 141 & 0.0 & 25 & 28 & 5 & 100 & 76 & 0.0 & 3 & 67 & 23 & 52 \\
\hline Lead & 15 & 91 & 0.0 & 15 & 0.0 & 4 & 0.0 & 63 & 0.0 & 2 & 0.0 & 16 & 0.0 \\
\hline Manganese & 300 & 141 & 0.0 & 24 & 17 & 5 & 40 & 76 & 0.0 & 3 & 0.0 & 23 & 17 \\
\hline Molybdenum & 40 & 91 & 0.0 & 15 & 0.0 & 4 & 0.0 & 63 & 0.0 & 2 & 0.0 & 16 & 0.0 \\
\hline Nickel & 100 & 91 & 0.0 & 15 & 0.0 & 4 & 0.0 & 63 & 0.0 & 2 & 0.0 & 16 & 0.0 \\
\hline Radon & 300 & 138 & 90 & 25 & 92 & 5 & 100 & 73 & 99 & 3 & 100 & 23 & 83 \\
\hline Selenium & 50 & 90 & 0.0 & 15 & 0.0 & 4 & 0.0 & 60 & 0.0 & 2 & 0.0 & 16 & 0.0 \\
\hline Silver & 100 & 91 & 0.0 & 15 & 0.0 & 4 & 0.0 & 63 & 0.0 & 2 & 0.0 & 16 & 0.0 \\
\hline Strontium & 4,000 & 30 & 0.0 & 9 & 0.0 & -- & -- & 31 & 0.0 & 1 & 0.0 & 12 & 0.0 \\
\hline Thallium & 2 & 12 & 0.0 & 2 & 0.0 & -- & -- & 31 & 0.0 & 1 & 0.0 & 12 & 0.0 \\
\hline Uranium & 30 & 141 & 2.8 & 25 & 0.0 & 5 & 0.0 & 76 & 7.9 & 3 & 0.0 & 23 & 0.0 \\
\hline Zinc & 2,000 & 91 & 0.0 & 15 & 0.0 & 4 & 0.0 & 62 & 0.0 & 2 & 0.0 & 16 & 0.0 \\
\hline $\begin{array}{l}\text { Number of ele } \\
\geq 1 \% \text { excee }\end{array}$ & $\begin{array}{l}\text { ents with } \\
\text { nce }\end{array}$ & & 2 & & 5 & & 3 & & 3 & & 2 & & 4 \\
\hline
\end{tabular}


Appendix 5. Summaries of logistic regression analyses of selected trace elements by major aquifer group.

[Dependent variable, binary ( 0 for non-occurrence, 1 for occurrence, above reporting level); EXP(B), exponentiated model coefficient (equivalent to odds ratio, $>1$ means direct relation and $<1$ means inverse relation); $c$ statistic is a measure of model discrimination (area under the receiver operating characteristics curve); Hosmer-Lemeshow ${ }^{1}$ statistic is a measure of model fit; N, continuous; B, binary; <, less than; --, not analyzed]

\begin{tabular}{|c|c|c|c|c|c|c|}
\hline $\begin{array}{l}\text { Dependent } \\
\text { variable }\end{array}$ & Explanatory variable & $\begin{array}{c}\text { Type of } \\
\text { variable }\end{array}$ & $\operatorname{EXP}(B)$ & $p$-value & $\begin{array}{c}c \text { statistic } \\
\text { (model discrimination) }\end{array}$ & $\begin{array}{c}\text { Hosmer- } \\
\text { Lemeshow statistic }\end{array}$ \\
\hline \multicolumn{7}{|c|}{ Unconsolidated sand and gravel aquifers-Dry climate } \\
\hline \multirow[t]{8}{*}{ Aluminum } & Silica & $\mathrm{N}$ & 0.957 & $<0.0001$ & 0.811 & 0.0709 \\
\hline & Dissolved oxygen & $\mathrm{N}$ & 0.872 & 0.0002 & & \\
\hline & Phosphate & $\mathrm{B}$ & 1.830 & 0.0031 & & \\
\hline & Nickel & $\mathrm{B}$ & 2.340 & $<0.0001$ & & \\
\hline & Lead & $\mathrm{B}$ & 6.280 & 0.0050 & & \\
\hline & Selenium & $\mathrm{B}$ & 0.420 & $<0.0001$ & & \\
\hline & Chromium & $\mathrm{B}$ & 2.014 & 0.0007 & & \\
\hline & Radon & $\mathrm{B}$ & 2.092 & 0.0008 & & \\
\hline \multirow[t]{3}{*}{ Arsenic } & Boron & $\mathrm{B}$ & 2.765 & 0.0460 & 0.952 & 0.001 \\
\hline & $\mathrm{pH}$ & $\mathrm{N}$ & 8.874 & 0.0073 & & \\
\hline & Silica & $\mathrm{N}$ & 1.170 & $<0.0001$ & & \\
\hline \multirow[t]{2}{*}{ Boron } & Arsenic & $\mathrm{B}$ & 5.112 & 0.0008 & 0.876 & 0.1068 \\
\hline & Total dissolved solids & $\mathrm{N}$ & 1.010 & $<0.0001$ & & \\
\hline \multirow[t]{6}{*}{ Iron } & $\mathrm{pH}$ & $\mathrm{N}$ & 0.100 & 0.0002 & 0.959 & 0.8788 \\
\hline & Dissolved oxygen & $\mathrm{N}$ & 0.170 & 0.0007 & & \\
\hline & Nitrate & $\mathrm{B}$ & 0.199 & 0.0081 & & \\
\hline & Uranium & $\mathrm{B}$ & 0.195 & 0.0006 & & \\
\hline & Manganese & $\mathrm{B}$ & 1.001 & 0.0016 & & \\
\hline & Well depth & $\mathrm{N}$ & 1.003 & 0.0392 & & \\
\hline \multirow[t]{3}{*}{ Manganese } & Nickel & $\mathrm{B}$ & 1.227 & 0.0002 & 0.915 & 0.0540 \\
\hline & Dissolved oxygen & $\mathrm{N}$ & 0.507 & $<0.0001$ & & \\
\hline & Well depth & $\mathrm{N}$ & 0.996 & $<0.0001$ & & \\
\hline \multirow[t]{7}{*}{ Molybdenum } & Fluoride & $\mathrm{B}$ & 5.277 & 0.0017 & 0.825 & 0.3994 \\
\hline & Uranium & $\mathrm{B}$ & 9.254 & $<0.0001$ & & \\
\hline & Selenium & $\mathrm{B}$ & 2.174 & 0.0038 & & \\
\hline & Dissolved oxygen & $\mathrm{N}$ & 0.782 & $<0.0001$ & & \\
\hline & $\mathrm{pH}$ & $\mathrm{N}$ & 4.918 & $<0.0001$ & & \\
\hline & Arsenic & $\mathrm{B}$ & 2.442 & 0.0014 & & \\
\hline & Manganese & $\mathrm{B}$ & 2.289 & 0.0043 & & \\
\hline \multirow[t]{5}{*}{ Nickel } & Total dissolved solids & $\mathrm{N}$ & 1.002 & $<0.0001$ & 0.807 & 0.1808 \\
\hline & Aluminum & $\mathrm{N}$ & 2.749 & $<0.0001$ & & \\
\hline & Copper & B & 1.686 & 0.0074 & & \\
\hline & Uranium & B & 2.341 & 0.0007 & & \\
\hline & $\mathrm{pH}$ & $\mathrm{N}$ & 0.456 & 0.0025 & & \\
\hline \multirow[t]{4}{*}{ Radon } & Tritium & B & 3.147 & 0.0002 & 0.703 & 0.9576 \\
\hline & Bromide & B & 3.839 & $<0.0001$ & & \\
\hline & $\mathrm{pH}$ & $\mathrm{N}$ & 3.691 & 0.0123 & & \\
\hline & Nitrate & B & 0.445 & 0.0147 & & \\
\hline
\end{tabular}


Appendix 5. Summaries of logistic regression analyses of selected trace elements by major aquifer group.-Continued

[Dependent variable, binary ( 0 for non-occurrence, 1 for occurrence, above reporting level); EXP(B), exponentiated model coefficient (equivalent to odds ratio, $>1$ means direct relation and $<1$ means inverse relation); $c$ statistic is a measure of model discrimination (area under the receiver operating characteristics curve); Hosmer-Lemeshow ${ }^{1}$ statistic is a measure of model fit; N, continuous; B, binary; <, less than; --, not analyzed]

\begin{tabular}{|c|c|c|c|c|c|c|}
\hline $\begin{array}{l}\text { Dependent } \\
\text { variable }\end{array}$ & Explanatory variable & $\begin{array}{c}\text { Type of } \\
\text { variable }\end{array}$ & $\operatorname{EXP}(B)$ & $p$-value & $\begin{array}{c}c \text { statistic } \\
\text { (model discrimination) }\end{array}$ & $\begin{array}{c}\text { Hosmer- } \\
\text { Lemeshow statistic }\end{array}$ \\
\hline \multicolumn{7}{|c|}{ Unconsolidated sand and gravel aquifers-Dry climate-Continued } \\
\hline \multirow[t]{10}{*}{ Selenium } & Specific conductance & $\mathrm{N}$ & 1.001 & 0.0005 & 0.884 & 0.1986 \\
\hline & Bromide & $\mathrm{B}$ & 2.316 & 0.0018 & & \\
\hline & Well depth & $\mathrm{N}$ & 1.003 & $<0.0001$ & & \\
\hline & Nitrate & $\mathrm{B}$ & 4.376 & $<0.0001$ & & \\
\hline & Aluminum & $\mathrm{B}$ & 0.377 & $<0.0001$ & & \\
\hline & Fluoride & $\mathrm{B}$ & 13.452 & 0.0003 & & \\
\hline & Manganese & $\mathrm{B}$ & 0.331 & $<0.0001$ & & \\
\hline & Molybdenum & $\mathrm{B}$ & 2.188 & 0.0204 & & \\
\hline & Uranium & $\mathrm{B}$ & 3.690 & 0.0010 & & \\
\hline & Iron & $\mathrm{B}$ & 0.417 & 0.0018 & & \\
\hline Strontium & Specific conductance & $\mathrm{N}$ & 1.005 & $<0.0001$ & 0.942 & 0.0828 \\
\hline \multirow[t]{8}{*}{ Uranium } & Total dissolved solids & $\mathrm{N}$ & 1.002 & 0.0005 & 0.908 & 0.7753 \\
\hline & Nitrogen as ammonia & $\mathrm{B}$ & 0.228 & 0.0001 & & \\
\hline & Phosphate & $\mathrm{B}$ & 0.329 & $<0.0001$ & & \\
\hline & Copper & $\mathrm{B}$ & 2.441 & 0.0022 & & \\
\hline & Iron & $\mathrm{B}$ & 0.434 & 0.0087 & & \\
\hline & Molybdenum & $\mathrm{B}$ & 9.775 & $<0.0001$ & & \\
\hline & Selenium & $\mathrm{B}$ & 5.292 & $<0.0001$ & & \\
\hline & Chromium & $\mathrm{B}$ & 2.144 & 0.0046 & & \\
\hline \multicolumn{7}{|c|}{ Unconsolidated sand and gravel aquifers-Humid climate } \\
\hline \multirow[t]{7}{*}{ Aluminum } & Calcium & $\mathrm{N}$ & 0.994 & 0.0079 & 0.877 & 0.9472 \\
\hline & Nitrogen as ammonia & $\mathrm{B}$ & 5.796 & 0.0095 & & \\
\hline & Dissolved oxygen & $\mathrm{N}$ & 0.834 & 0.0005 & & \\
\hline & Arsenic & $\mathrm{B}$ & 2.166 & 0.0359 & & \\
\hline & Fluoride & $\mathrm{B}$ & 0.251 & 0.0007 & & \\
\hline & Nickel & $\mathrm{B}$ & 2.650 & 0.0085 & & \\
\hline & Chromium & $\mathrm{B}$ & 6.924 & $<0.0001$ & & \\
\hline \multirow[t]{7}{*}{ Arsenic } & $\mathrm{pH}$ & $\mathrm{N}$ & 1.695 & 0.0077 & 0.807 & 0.0118 \\
\hline & Potassium & $\mathrm{N}$ & 1.229 & 0.0002 & & \\
\hline & Silica & $\mathrm{N}$ & 1.042 & $<0.0001$ & & \\
\hline & Phosphate & $\mathrm{B}$ & 2.602 & $<0.0001$ & & \\
\hline & Aluminum & $\mathrm{B}$ & 2.826 & 0.0003 & & \\
\hline & Copper & $\mathrm{B}$ & 0.405 & 0.0005 & & \\
\hline & Uranium & $\mathrm{B}$ & 2.974 & 0.0001 & & \\
\hline \multirow[t]{3}{*}{ Boron } & Total dissolved solids & $\mathrm{N}$ & 1.006 & $<0.0001$ & 0.901 & 0.0445 \\
\hline & Aluminum & $\mathrm{B}$ & 2.751 & 0.0197 & & \\
\hline & Molybdenum & $\mathrm{B}$ & 3.595 & 0.0024 & & \\
\hline
\end{tabular}


Appendix 5. Summaries of logistic regression analyses of selected trace elements by major aquifer group.—Continued

[Dependent variable, binary ( 0 for non-occurrence, 1 for occurrence, above reporting level); EXP(B), exponentiated model coefficient (equivalent to odds ratio, $>1$ means direct relation and $<1$ means inverse relation); $c$ statistic is a measure of model discrimination (area under the receiver operating characteristics curve); Hosmer-Lemeshow ${ }^{1}$ statistic is a measure of model fit; N, continuous; B, binary; <, less than; --, not analyzed]

\begin{tabular}{|c|c|c|c|c|c|c|}
\hline $\begin{array}{l}\text { Dependent } \\
\text { variable }\end{array}$ & Explanatory variable & $\begin{array}{c}\text { Type of } \\
\text { variable }\end{array}$ & $\operatorname{EXP}(B)$ & $p$-value & $\begin{array}{c}c \text { statistic } \\
\text { (model discrimination) }\end{array}$ & $\begin{array}{c}\text { Hosmer- } \\
\text { Lemeshow statistic }\end{array}$ \\
\hline \multicolumn{7}{|c|}{ Unconsolidated sand and gravel aquifers-Humid climate-Continued } \\
\hline \multirow[t]{7}{*}{ Copper } & $\mathrm{pH}$ & $\mathrm{N}$ & 0.449 & 0.0003 & 0.832 & 0.4555 \\
\hline & Bromide & $\mathrm{B}$ & 0.362 & 0.0002 & & \\
\hline & Sulfate & $\mathrm{N}$ & 1.015 & $<0.0001$ & & \\
\hline & Lead & $\mathrm{B}$ & 4.137 & 0.0004 & & \\
\hline & Uranium & $\mathrm{B}$ & 3.194 & 0.0002 & & \\
\hline & Zinc & $\mathrm{B}$ & 5.423 & $<0.0001$ & & \\
\hline & Selenium & $\mathrm{B}$ & 2.273 & 0.0537 & & \\
\hline \multirow[t]{3}{*}{ Iron } & Dissolved oxygen & $\mathrm{N}$ & 0.350 & $<0.0001$ & 0.939 & $<0.0001$ \\
\hline & $\mathrm{pH}$ & $\mathrm{N}$ & 0.308 & $<0.0001$ & & \\
\hline & Nitrate & $\mathrm{B}$ & 0.096 & $<0.0001$ & & \\
\hline \multirow[t]{4}{*}{ Manganese } & Dissolved oxygen & $\mathrm{N}$ & 0.436 & $<0.0001$ & 0.884 & 0.8578 \\
\hline & $\mathrm{pH}$ & $\mathrm{N}$ & 1.961 & 0.0014 & & \\
\hline & Copper & $\mathrm{B}$ & 0.465 & 0.0056 & & \\
\hline & Well depth & $\mathrm{N}$ & 0.998 & 0.00009 & & \\
\hline \multirow[t]{8}{*}{ Molybdenum } & Total dissolved solids & $\mathrm{N}$ & 1.003 & $<0.0001$ & 0.903 & 0.1047 \\
\hline & Silica & $\mathrm{N}$ & 0.981 & 0.0039 & & \\
\hline & Well depth & $\mathrm{N}$ & 1.006 & $<0.0001$ & & \\
\hline & Fluoride & $\mathrm{B}$ & 2.264 & 0.0002 & & \\
\hline & Aluminum & $\mathrm{B}$ & 2.366 & 0.0305 & & \\
\hline & Manganese & $\mathrm{B}$ & 2.559 & 0.0010 & & \\
\hline & Uranium & $\mathrm{B}$ & 2.869 & $<0.0001$ & & \\
\hline & Chromium & B & 0.489 & 0.0222 & & \\
\hline \multirow[t]{8}{*}{ Nickel } & Temperature & $\mathrm{N}$ & 1.125 & $<0.0001$ & 0.842 & 0.0687 \\
\hline & $\mathrm{pH}$ & $\mathrm{N}$ & 0.419 & 0.0001 & & \\
\hline & Sodium & $\mathrm{N}$ & 1.011 & 0.0009 & & \\
\hline & Nitrogen as ammonia & B & 0.420 & 0.0031 & & \\
\hline & Aluminum & $\mathrm{B}$ & 3.589 & 0.0012 & & \\
\hline & Selenium & $\mathrm{B}$ & 0.340 & 0.0074 & & \\
\hline & Cobalt & $\mathrm{B}$ & 17.385 & 0.0003 & & \\
\hline & Chromium & $\mathrm{B}$ & 3.465 & $<0.0001$ & & \\
\hline \multirow[t]{5}{*}{ Radon } & Chromium & $\mathrm{B}$ & 0.168 & $<0.0001$ & 0.867 & $<0.0001$ \\
\hline & Well depth & $\mathrm{N}$ & 0.998 & 0.0004 & & \\
\hline & Uranium & $\mathrm{B}$ & 3.718 & 0.0002 & & \\
\hline & Dissolved oxygen & $\mathrm{N}$ & 1.299 & 0.0006 & & \\
\hline & Manganese & $\mathrm{B}$ & 0.284 & 0.0048 & & \\
\hline \multirow[t]{3}{*}{ Selenium } & Total dissolved solids & $\mathrm{N}$ & 1.003 & $<0.0001$ & 0.866 & 0.0187 \\
\hline & Uranium & $\mathrm{B}$ & 2.655 & 0.0119 & & \\
\hline & Well depth & $\mathrm{N}$ & 1.002 & $<0.0001$ & & \\
\hline
\end{tabular}


Appendix 5. Summaries of logistic regression analyses of selected trace elements by major aquifer group.-Continued

[Dependent variable, binary ( 0 for non-occurrence, 1 for occurrence, above reporting level); EXP(B), exponentiated model coefficient (equivalent to odds ratio, $>1$ means direct relation and $<1$ means inverse relation); $c$ statistic is a measure of model discrimination (area under the receiver operating characteristics curve); Hosmer-Lemeshow ${ }^{1}$ statistic is a measure of model fit; N, continuous; B, binary; <, less than; --, not analyzed]

\begin{tabular}{|c|c|c|c|c|c|c|}
\hline $\begin{array}{l}\text { Dependent } \\
\text { variable }\end{array}$ & Explanatory variable & $\begin{array}{c}\text { Type of } \\
\text { variable }\end{array}$ & $\operatorname{EXP}(B)$ & $p$-value & $\begin{array}{c}c \text { statistic } \\
\text { (model discrimination) }\end{array}$ & $\begin{array}{c}\text { Hosmer- } \\
\text { Lemeshow statistic }\end{array}$ \\
\hline \multicolumn{7}{|c|}{ Unconsolidated sand and gravel aquifers-Humid climate-Continued } \\
\hline Strontium & Specific conductance & $\mathrm{N}$ & 1.006 & $<0.0001$ & 0.972 & 0.6053 \\
\hline \multirow[t]{9}{*}{ Uranium } & $\mathrm{pH}$ & $\mathrm{N}$ & 2.577 & 0.0008 & 0.912 & 0.5779 \\
\hline & Silica & $\mathrm{N}$ & 0.964 & 0.0002 & & \\
\hline & Total dissolved solids & $\mathrm{N}$ & 1.004 & $<0.0001$ & & \\
\hline & Nitrate & $\mathrm{B}$ & 3.367 & 0.0002 & & \\
\hline & Nitrogen as ammonia & $\mathrm{B}$ & 0.102 & $<0.0001$ & & \\
\hline & Copper & $\mathrm{B}$ & 1.865 & 0.0386 & & \\
\hline & Arsenic & B & 3.571 & 0.0002 & & \\
\hline & Iron & $\mathrm{B}$ & 0.456 & 0.0233 & & \\
\hline & Molybdenum & $\mathrm{B}$ & 1.921 & 0.0336 & & \\
\hline \multirow[t]{5}{*}{ Zinc } & Silica & $\mathrm{N}$ & 1.023 & 0.0068 & 0.852 & 0.1797 \\
\hline & Phosphate & B & 0.526 & 0.0283 & & \\
\hline & Copper & $\mathrm{B}$ & 9.011 & $<0.0001$ & & \\
\hline & Chromium & $\mathrm{B}$ & 0.115 & $<0.0001$ & & \\
\hline & Dissolved oxygen & $\mathrm{N}$ & 1.237 & 0.0002 & & \\
\hline \multicolumn{7}{|c|}{ Glacial unconsolidated sand and gravel aquifers } \\
\hline \multirow[t]{5}{*}{ Aluminum } & $\mathrm{pH}$ & $\mathrm{N}$ & 0.530 & 0.0006 & 0.851 & 0.0904 \\
\hline & Iron & $\mathrm{B}$ & 0.433 & 0.0087 & & \\
\hline & Chromium & $\mathrm{B}$ & 16.366 & $<0.0001$ & & \\
\hline & Manganese & B & 5.327 & $<0.0001$ & & \\
\hline & Nickel & $\mathrm{B}$ & 3.096 & $<0.0001$ & & \\
\hline \multirow[t]{6}{*}{ Arsenic } & $\mathrm{pH}$ & $\mathrm{N}$ & 2.312 & 0.0001 & 0.801 & 0.7528 \\
\hline & Silica & $\mathrm{N}$ & 1.066 & 0.0007 & & \\
\hline & Dissolved oxygen & $\mathrm{N}$ & 0.819 & $<0.0001$ & & \\
\hline & Molybdenum & B & 2.518 & 0.0005 & & \\
\hline & Uranium & B & 1.555 & 0.0966 & & \\
\hline & Well depth & $\mathrm{N}$ & 1.008 & 0.0002 & & \\
\hline \multirow[t]{5}{*}{ Boron } & $\mathrm{pH}$ & $\mathrm{N}$ & 2.695 & 0.0105 & 0.821 & 0.2896 \\
\hline & Bromide & B & 4.036 & 0.0007 & & \\
\hline & Molybdenum & B & 2.396 & 0.0337 & & \\
\hline & Temperature & $\mathrm{N}$ & 1.144 & 0.0055 & & \\
\hline & Potassium & $\mathrm{N}$ & 1.088 & 0.0251 & & \\
\hline \multirow[t]{8}{*}{ Copper } & Potassium & $\mathrm{N}$ & 1.094 & 0.0337 & 0.799 & 0.6210 \\
\hline & Nitrate & B & 3.068 & $<0.0001$ & & \\
\hline & Sulfate & $\mathrm{N}$ & 1.011 & $<0.0001$ & & \\
\hline & Aluminum & B & 0.380 & $<0.0001$ & & \\
\hline & Iron & B & 0.478 & 0.0026 & & \\
\hline & Molybdenum & $\mathrm{B}$ & 0.363 & $<0.0001$ & & \\
\hline & Uranium & B & 2.160 & 0.0078 & & \\
\hline & Zinc & B & 4.842 & $<0.0001$ & & \\
\hline
\end{tabular}


Appendix 5. Summaries of logistic regression analyses of selected trace elements by major aquifer group.-Continued

[Dependent variable, binary ( 0 for non-occurrence, 1 for occurrence, above reporting level); EXP(B), exponentiated model coefficient (equivalent to odds ratio, $>1$ means direct relation and $<1$ means inverse relation); $c$ statistic is a measure of model discrimination (area under the receiver operating characteristics curve); Hosmer-Lemeshow ${ }^{1}$ statistic is a measure of model fit; N, continuous; B, binary; <, less than; --, not analyzed]

\begin{tabular}{|c|c|c|c|c|c|c|}
\hline $\begin{array}{c}\text { Dependent } \\
\text { variable }\end{array}$ & Explanatory variable & $\begin{array}{c}\text { Type of } \\
\text { variable }\end{array}$ & $\operatorname{EXP}(B)$ & $p$-value & $\begin{array}{c}c \text { statistic } \\
\text { (model discrimination) }\end{array}$ & $\begin{array}{c}\text { Hosmer- } \\
\text { Lemeshow statistic }\end{array}$ \\
\hline \multicolumn{7}{|c|}{ Glacial unconsolidated sand and gravel aquifers-Continued } \\
\hline \multirow[t]{8}{*}{ Iron } & $\mathrm{pH}$ & $\mathrm{N}$ & 0.326 & $<0.0001$ & 0.928 & 0.9070 \\
\hline & Total dissolved solids & $\mathrm{N}$ & 1.002 & 0.0316 & & \\
\hline & Well depth & $\mathrm{N}$ & 1.011 & 0.0018 & & \\
\hline & Dissolved oxygen & $\mathrm{N}$ & 0.517 & $<0.0001$ & & \\
\hline & Copper & $\mathrm{B}$ & 0.326 & 0.0017 & & \\
\hline & Uranium & $\mathrm{B}$ & 0.311 & 0.0034 & & \\
\hline & Chromium & $\mathrm{B}$ & 0.420 & 0.0161 & & \\
\hline & Radon & $\mathrm{B}$ & 0.110 & $<0.0001$ & & \\
\hline \multirow[t]{8}{*}{ Manganese } & $\mathrm{pH}$ & $\mathrm{N}$ & 0.607 & 0.0095 & 0.857 & 0.8400 \\
\hline & Well depth & $\mathrm{N}$ & 0.986 & $<0.0001$ & & \\
\hline & Dissolved oxygen & $\mathrm{N}$ & 0.812 & $<0.0001$ & & \\
\hline & Arsenic & B & 2.385 & 0.0033 & & \\
\hline & Iron & B & 2.252 & 0.0034 & & \\
\hline & Uranium & B & 3.112 & 0.0002 & & \\
\hline & Cobalt & $\mathrm{B}$ & 4.702 & 0.0001 & & \\
\hline & Nitrate & B & 0.426 & 0.0043 & & \\
\hline \multirow[t]{9}{*}{ Molybdenum } & Specific conductance & $\mathrm{N}$ & 1.002 & $<0.0001$ & 0.893 & 0.2575 \\
\hline & $\mathrm{pH}$ & $\mathrm{N}$ & 3.651 & $<0.0001$ & & \\
\hline & Silica & $\mathrm{N}$ & 0.911 & 0.0002 & & \\
\hline & Bromide & $\mathrm{B}$ & 0.383 & 0.0040 & & \\
\hline & Dissolved oxygen & $\mathrm{N}$ & 0.899 & 0.0415 & & \\
\hline & Arsenic & B & 2.914 & 0.0016 & & \\
\hline & Fluoride & B & 10 & $<0.0001$ & & \\
\hline & Manganese & B & 4.157 & 0.0002 & & \\
\hline & Nickel & B & 2.957 & 0.0004 & & \\
\hline \multirow[t]{4}{*}{ Nickel } & Aluminum & B & 3.410 & $<0.0001$ & 0.768 & 0.0984 \\
\hline & Molybdenum & $\mathrm{B}$ & 2.342 & $<0.0001$ & & \\
\hline & Zinc & B & 2.862 & 0.0002 & & \\
\hline & Cobalt & $\mathrm{B}$ & 6.181 & $<0.0001$ & & \\
\hline \multirow[t]{4}{*}{ Lead } & Magnesium & $\mathrm{N}$ & 0.957 & 0.0108 & 0.825 & 0.5371 \\
\hline & Chloride & $\mathrm{N}$ & 1.012 & 0.0003 & & \\
\hline & Potassium & $\mathrm{N}$ & 0.582 & 0.0254 & & \\
\hline & Copper & B & 1.063 & $<0.0001$ & & \\
\hline \multirow[t]{4}{*}{ Radon } & $\mathrm{pH}$ & $\mathrm{N}$ & 0.416 & 0.0006 & 0.933 & 0.3919 \\
\hline & Nitrate & B & 3.015 & 0.0004 & & \\
\hline & Sulfate & $\mathrm{N}$ & 0.989 & 0.0025 & & \\
\hline & Arsenic & B & 0.349 & 0.0012 & & \\
\hline
\end{tabular}


Appendix 5. Summaries of logistic regression analyses of selected trace elements by major aquifer group.-Continued

[Dependent variable, binary ( 0 for non-occurrence, 1 for occurrence, above reporting level); EXP(B), exponentiated model coefficient (equivalent to odds ratio, $>1$ means direct relation and $<1$ means inverse relation); $c$ statistic is a measure of model discrimination (area under the receiver operating characteristics curve); Hosmer-Lemeshow ${ }^{1}$ statistic is a measure of model fit; N, continuous; B, binary; <, less than; --, not analyzed]

\begin{tabular}{|c|c|c|c|c|c|c|}
\hline $\begin{array}{c}\text { Dependent } \\
\text { variable }\end{array}$ & Explanatory variable & $\begin{array}{c}\text { Type of } \\
\text { variable }\end{array}$ & $\operatorname{EXP}(B)$ & $p$-value & $\begin{array}{c}c \text { statistic } \\
\text { (model discrimination) }\end{array}$ & $\begin{array}{c}\text { Hosmer- } \\
\text { Lemeshow statistic }\end{array}$ \\
\hline \multicolumn{7}{|c|}{ Glacial unconsolidated sand and gravel aquifers-Continued } \\
\hline \multirow[t]{5}{*}{ Radon-Continued } & Fluoride & $\mathrm{B}$ & 2.356 & 0.0107 & & \\
\hline & Iron & $\mathrm{B}$ & 0.325 & 0.0003 & & \\
\hline & Molybdenum & $\mathrm{B}$ & 0.466 & 0.0211 & & \\
\hline & Cobalt & $\mathrm{B}$ & 2.427 & 0.0213 & & \\
\hline & Chromium & $\mathrm{B}$ & 0.542 & 0.0271 & & \\
\hline \multirow[t]{3}{*}{ Selenium } & Nitrate & $\mathrm{B}$ & 4.384 & 0.0004 & 0.797 & 0.9472 \\
\hline & Uranium & $\mathrm{B}$ & 5.161 & $<0.0001$ & & \\
\hline & Manganese & $\mathrm{B}$ & 0.250 & 0.0009 & & \\
\hline \multirow[t]{5}{*}{ Strontium } & Calcium & $\mathrm{N}$ & 1.020 & $<0.0001$ & 0.815 & 0.2493 \\
\hline & Sodium & $\mathrm{N}$ & 1.010 & 0.0300 & & \\
\hline & Dissolved oxygen & $\mathrm{N}$ & .0865 & 0.0105 & & \\
\hline & Manganese & $\mathrm{B}$ & 0.280 & 0.0060 & & \\
\hline & Uranium & $\mathrm{B}$ & 5.062 & 0.0001 & & \\
\hline \multirow[t]{7}{*}{ Uranium } & Magnesium & $\mathrm{N}$ & 1.057 & $<0.0001$ & 0.876 & 0.8847 \\
\hline & Silica & $\mathrm{N}$ & 0.918 & 0.0015 & & \\
\hline & Well depth & $\mathrm{N}$ & 0.971 & $<0.0001$ & & \\
\hline & Fluoride & $\mathrm{B}$ & 3.321 & 0.0012 & & \\
\hline & Nickel & $\mathrm{B}$ & 3.173 & 0.0011 & & \\
\hline & Manganese & $\mathrm{B}$ & 5.226 & 0.0005 & & \\
\hline & Selenium & $\mathrm{B}$ & 4.092 & 0.0015 & & \\
\hline \multirow[t]{7}{*}{ Zinc } & Temperature & $\mathrm{N}$ & 0.920 & 0.0028 & 0.753 & 0.8044 \\
\hline & Specific conductance & $\mathrm{N}$ & 0.999 & 0.0117 & & \\
\hline & Silica & $\mathrm{N}$ & 1.090 & 0.0063 & & \\
\hline & Copper & $\mathrm{B}$ & 4.161 & $<0.0001$ & & \\
\hline & Nickel & $\mathrm{B}$ & 2.247 & 0.0034 & & \\
\hline & Radon & $\mathrm{B}$ & 0.404 & 0.0016 & & \\
\hline & Cobalt & $\mathrm{B}$ & 3.764 & 0.0108 & & \\
\hline \multicolumn{7}{|c|}{ Semiconsolidated sand aquifers } \\
\hline \multirow[t]{6}{*}{ Aluminum } & $\mathrm{pH}$ & $\mathrm{N}$ & 0.363 & $<0.0001$ & 0.856 & 0.7376 \\
\hline & Silica & $\mathrm{N}$ & 0.938 & $<0.0001$ & & \\
\hline & Nitrogen as ammonia & $\mathrm{B}$ & 2.974 & 0.0250 & & \\
\hline & Nickel & B & 3.211 & 0.0031 & & \\
\hline & Iron & B & 3.062 & 0.0063 & & \\
\hline & Well depth & $\mathrm{N}$ & 0.997 & 0.0340 & & \\
\hline \multirow[t]{4}{*}{ Arsenic } & Dissolved oxygen & $\mathrm{N}$ & 0.688 & 0.0003 & 0.824 & 0.2713 \\
\hline & Molybdenum & $\mathrm{B}$ & 3.198 & 0.0013 & & \\
\hline & Cobalt & $\mathrm{B}$ & 1.908 & 0.0653 & & \\
\hline & Silica & $\mathrm{B}$ & 1.039 & 0.0019 & & \\
\hline
\end{tabular}


Appendix 5. Summaries of logistic regression analyses of selected trace elements by major aquifer group.-Continued

[Dependent variable, binary ( 0 for non-occurrence, 1 for occurrence, above reporting level); EXP(B), exponentiated model coefficient (equivalent to odds ratio, $>1$ means direct relation and $<1$ means inverse relation); $c$ statistic is a measure of model discrimination (area under the receiver operating characteristics curve); Hosmer-Lemeshow ${ }^{1}$ statistic is a measure of model fit; N, continuous; B, binary; <, less than; --, not analyzed]

\begin{tabular}{|c|c|c|c|c|c|c|}
\hline $\begin{array}{c}\text { Dependent } \\
\text { variable }\end{array}$ & Explanatory variable & $\begin{array}{c}\text { Type of } \\
\text { variable }\end{array}$ & $\operatorname{EXP}(B)$ & $p$-value & $\begin{array}{c}c \text { statistic } \\
\text { (model discrimination) }\end{array}$ & $\begin{array}{c}\text { Hosmer- } \\
\text { Lemeshow statistic }\end{array}$ \\
\hline \multicolumn{7}{|c|}{ Semiconsolidated sand aquifers - Continued } \\
\hline \multirow[t]{3}{*}{ Boron } & Magnesium & $\mathrm{N}$ & 1.142 & 0.0006 & 0.784 & 0.2073 \\
\hline & Dissolved oxygen & $\mathrm{N}$ & 0.888 & 0.0577 & & \\
\hline & $\mathrm{pH}$ & $\mathrm{N}$ & 1.646 & 0.0192 & & \\
\hline \multirow[t]{3}{*}{ Iron } & Dissolved oxygen & $\mathrm{N}$ & 0.692 & $<0.0001$ & 0.812 & 0.4138 \\
\hline & Nitrate & $\mathrm{B}$ & 0.192 & 0.0011 & & \\
\hline & Uranium & $\mathrm{B}$ & 0.248 & 0.0077 & & \\
\hline \multirow[t]{5}{*}{ Manganese } & Well depth & $\mathrm{N}$ & 0.995 & 0.0010 & 0.817 & 0.4914 \\
\hline & Dissolved oxygen & $\mathrm{N}$ & 0.702 & $<0.0001$ & & \\
\hline & Phosphate & $\mathrm{B}$ & 3.446 & 0.0005 & & \\
\hline & Zinc & $\mathrm{B}$ & 4.638 & 0.0006 & & \\
\hline & Chromium & $\mathrm{B}$ & 0.519 & 0.0472 & & \\
\hline \multirow[t]{4}{*}{ Molybdenum } & $\mathrm{pH}$ & $\mathrm{N}$ & 23.641 & 0.0007 & 0.971 & 0.9381 \\
\hline & Total dissolved solids & $\mathrm{N}$ & 1.005 & 0.0728 & & \\
\hline & Arsenic & $\mathrm{B}$ & 24.806 & 0.0022 & & \\
\hline & Radon & $\mathrm{B}$ & 9.477 & 0.0079 & & \\
\hline \multirow[t]{5}{*}{ Nickel } & Total dissolved solids & $\mathrm{N}$ & 1.001 & 0.0510 & 0.818 & 0.1158 \\
\hline & Iron & $\mathrm{B}$ & 0.482 & 0.0120 & & \\
\hline & Manganese & $\mathrm{B}$ & 4.4523 & 0.0039 & & \\
\hline & Cobalt & $\mathrm{B}$ & 15.759 & $<0.0001$ & & \\
\hline & Chromium & $\mathrm{B}$ & 2.803 & 0.0002 & & \\
\hline \multirow[t]{2}{*}{ Radon } & Nitrate & $\mathrm{B}$ & 2.839 & 0.00018 & 0.692 & 0.9451 \\
\hline & Molybdenum & $\mathrm{B}$ & 10.720 & $<0.0001$ & & \\
\hline \multirow[t]{4}{*}{ Selenium } & Nitrate & $\mathrm{B}$ & 3.720 & 0.0016 & 0.785 & 0.0469 \\
\hline & Total dissolved solids & $\mathrm{N}$ & 1.001 & 0.0096 & & \\
\hline & Iron & $\mathrm{B}$ & 0.296 & 0.0020 & & \\
\hline & Arsenic & $\mathrm{B}$ & 3.016 & 0.0133 & & \\
\hline Strontium & Total dissolved solids & $\mathrm{N}$ & 1.011 & $<0.0001$ & 0.849 & $<0.0001$ \\
\hline \multirow[t]{4}{*}{ Uranium } & Molybdenum & $\mathrm{B}$ & 17.527 & $<0.0001$ & 0.926 & 0.0022 \\
\hline & Nitrogen as ammonia & $\mathrm{B}$ & 0.074 & 0.0009 & & \\
\hline & Sulfate & $\mathrm{N}$ & 1.018 & 0.0109 & & \\
\hline & Bicarbonate & $\mathrm{N}$ & 1.005 & 0.0056 & & \\
\hline
\end{tabular}


Appendix 5. Summaries of logistic regression analyses of selected trace elements by major aquifer group.-Continued

[Dependent variable, binary ( 0 for non-occurrence, 1 for occurrence, above reporting level); EXP(B), exponentiated model coefficient (equivalent to odds ratio, $>1$ means direct relation and $<1$ means inverse relation); $c$ statistic is a measure of model discrimination (area under the receiver operating characteristics curve); Hosmer-Lemeshow ${ }^{1}$ statistic is a measure of model fit; N, continuous; B, binary; <, less than; --, not analyzed]

\begin{tabular}{|c|c|c|c|c|c|c|}
\hline $\begin{array}{c}\text { Dependent } \\
\text { variable }\end{array}$ & Explanatory variable & $\begin{array}{c}\text { Type of } \\
\text { variable }\end{array}$ & $\operatorname{EXP}(B)$ & $p$-value & $\begin{array}{c}c \text { statistic } \\
\text { (model discrimination) }\end{array}$ & $\begin{array}{c}\text { Hosmer- } \\
\text { Lemeshow statistic }\end{array}$ \\
\hline \multicolumn{7}{|c|}{ Sandstone aquifers } \\
\hline \multirow[t]{5}{*}{ Aluminum } & Bromide & $\mathrm{B}$ & 0.142 & 0.0030 & 0.954 & 0.9446 \\
\hline & Nitrogen as ammonia & $\mathrm{B}$ & 37.779 & $<0.0001$ & & \\
\hline & Phosphate & $\mathrm{B}$ & 0.194 & 0.0049 & & \\
\hline & Nickel & $\mathrm{B}$ & 8.611 & 0.0005 & & \\
\hline & Chromium & $\mathrm{B}$ & 54.073 & $<0.0001$ & & \\
\hline \multirow[t]{3}{*}{ Arsenic } & Silica & $\mathrm{N}$ & 1.040 & 0.0498 & 0.765 & 0.4879 \\
\hline & Molybdenum & $\mathrm{B}$ & 5.719 & $<0.0001$ & & \\
\hline & Uranium & $\mathrm{B}$ & 0.0278 & 0.0278 & & \\
\hline Boron & Sodium & $\mathrm{N}$ & 2.0005 & $<0.0001$ & 0.972 & 0.7816 \\
\hline \multirow[t]{6}{*}{ Iron } & $\mathrm{pH}$ & $\mathrm{N}$ & 0.231 & 0.0002 & 0.953 & 0.1861 \\
\hline & Sodium & $\mathrm{N}$ & 0.991 & 0.0205 & & \\
\hline & Nitrogen as ammonia & $\mathrm{B}$ & 28.063 & $<0.0001$ & & \\
\hline & Dissolved oxygen & $\mathrm{N}$ & 0.525 & $<0.0001$ & & \\
\hline & Arsenic & $\mathrm{B}$ & 3.895 & 0.0416 & & \\
\hline & Molybdenum & $\mathrm{B}$ & 0.206 & 0.0398 & & \\
\hline \multirow[t]{5}{*}{ Manganese } & $\mathrm{pH}$ & $\mathrm{N}$ & 0.189 & $<0.0001$ & 0.922 & 0.9936 \\
\hline & Total dissolved solids & $\mathrm{N}$ & 1.001 & 0.0095 & & \\
\hline & Nitrate & $\mathrm{B}$ & 0.129 & 0.0064 & & \\
\hline & Iron & $\mathrm{B}$ & 17.920 & $<0.0001$ & & \\
\hline & Copper & $\mathrm{B}$ & 0.128 & $<0.0001$ & & \\
\hline \multirow[t]{5}{*}{ Molybdenum } & $\mathrm{pH}$ & $\mathrm{N}$ & 6.523 & $<0.0001$ & 0.929 & 0.0003 \\
\hline & Bromide & $\mathrm{B}$ & 6.187 & $<0.0001$ & & \\
\hline & Well depth & $\mathrm{N}$ & 1.007 & 0.0010 & & \\
\hline & Arsenic & $\mathrm{B}$ & 6.655 & 0.0004 & & \\
\hline & Uranium & B & 6.948 & $<0.0001$ & & \\
\hline \multirow[t]{8}{*}{ Nickel } & Specific conductance & $\mathrm{N}$ & 0.999 & 0.0051 & 0.880 & 0.532 \\
\hline & Calcium & $\mathrm{N}$ & 1.025 & 0.0003 & & \\
\hline & Silica & $\mathrm{N}$ & 1.142 & 0.0013 & & \\
\hline & Well depth & $\mathrm{N}$ & 1.006 & 0.0133 & & \\
\hline & Aluminum & $\mathrm{B}$ & 10.755 & $<0.0001$ & & \\
\hline & Copper & $\mathrm{B}$ & 6.989 & $<0.0001$ & & \\
\hline & Manganese & $\mathrm{B}$ & 6.749 & 0.0015 & & \\
\hline & Zinc & $\mathrm{B}$ & 8.674 & 0.0119 & & \\
\hline \multirow[t]{4}{*}{ Radon } & Temperature & $\mathrm{N}$ & 0.798 & 0.0237 & 0.835 & 0.4521 \\
\hline & Nitrate & B & 28.709 & $<0.0001$ & & \\
\hline & Phosphate & $\mathrm{B}$ & 0.482 & 0.0551 & & \\
\hline & Molybdenum & $\mathrm{B}$ & 9.670 & $<0.0001$ & & \\
\hline
\end{tabular}


Appendix 5. Summaries of logistic regression analyses of selected trace elements by major aquifer group.-Continued

[Dependent variable, binary ( 0 for non-occurrence, 1 for occurrence, above reporting level); EXP(B), exponentiated model coefficient (equivalent to odds ratio, $>1$ means direct relation and $<1$ means inverse relation); $c$ statistic is a measure of model discrimination (area under the receiver operating characteristics curve); Hosmer-Lemeshow ${ }^{1}$ statistic is a measure of model fit; N, continuous; B, binary; <, less than; --, not analyzed]

\begin{tabular}{|c|c|c|c|c|c|c|}
\hline $\begin{array}{c}\text { Dependent } \\
\text { variable }\end{array}$ & Explanatory variable & $\begin{array}{c}\text { Type of } \\
\text { variable }\end{array}$ & $\operatorname{EXP}(B)$ & p-value & $\begin{array}{c}c \text { statistic } \\
\text { (model discrimination) }\end{array}$ & $\begin{array}{c}\text { Hosmer- } \\
\text { Lemeshow statistic }\end{array}$ \\
\hline \multicolumn{7}{|c|}{ Sandstone aquifers-Continued } \\
\hline \multirow[t]{3}{*}{ Selenium } & Sodium & $\mathrm{N}$ & 1.005 & $<0.0001$ & 0.864 & 0.5721 \\
\hline & Uranium & $\mathrm{B}$ & 6.970 & $<0.0001$ & & \\
\hline & Iron & $\mathrm{B}$ & 0.084 & 0.0009 & & \\
\hline Strontium & Total dissolved solids & $\mathrm{N}$ & 1.002 & 0.0118 & 0.814 & 0.0241 \\
\hline \multirow[t]{3}{*}{ Uranium } & Magnesium & $\mathrm{N}$ & 1.087 & $<0.0001$ & 0.923 & 0.5177 \\
\hline & Nitrogen as ammonia & $\mathrm{B}$ & 0.055 & $<0.0001$ & & \\
\hline & Molybdenum & $\mathrm{B}$ & 24.836 & $<0.0001$ & & \\
\hline \multicolumn{7}{|c|}{ Sandstone and carbonate-rock aquifers } \\
\hline \multirow[t]{6}{*}{ Aluminum } & Calcium & $\mathrm{N}$ & 0.986 & 0.0007 & 0.951 & 0.5763 \\
\hline & Sodium & $\mathrm{N}$ & 1.094 & 0.0161 & & \\
\hline & Copper & $\mathrm{B}$ & 8.843 & 0.0011 & & \\
\hline & Manganese & $\mathrm{B}$ & 19.088 & 0.0019 & & \\
\hline & Zinc & $\mathrm{B}$ & 21.719 & $<0.0001$ & & \\
\hline & Chromium & $\mathrm{B}$ & 24.352 & 0.0003 & & \\
\hline \multirow[t]{3}{*}{ Arsenic } & Temperature & $\mathrm{N}$ & 0.803 & 0.0010 & 0.827 & 0.8154 \\
\hline & Molybdenum & $\mathrm{B}$ & 11.318 & 0.0007 & & \\
\hline & Zinc & $\mathrm{B}$ & 0.103 & 0.0081 & & \\
\hline Boron & -- & & & & & \\
\hline \multirow[t]{3}{*}{ Iron } & Copper & $\mathrm{B}$ & 0.215 & 0.0066 & 0.907 & 0.1299 \\
\hline & Sulfate & $\mathrm{N}$ & 1.001 & 0.0375 & & \\
\hline & Manganese & $\mathrm{B}$ & 46.877 & 0.0003 & & \\
\hline \multirow[t]{4}{*}{ Manganese } & Temperature & $\mathrm{N}$ & 0.696 & 0.0001 & 0.906 & 0.0947 \\
\hline & Iron & $\mathrm{B}$ & 23.787 & $<0.0001$ & & \\
\hline & Chromium & $\mathrm{B}$ & 0.253 & 0.0472 & & \\
\hline & Radon & $\mathrm{B}$ & 0.143 & 0.0112 & & \\
\hline Molybdenum & -- & & & & & \\
\hline \multirow[t]{4}{*}{ Nickel } & Specific conductance & $\mathrm{N}$ & 1.006 & $<0.0001$ & 0.807 & 0.4762 \\
\hline & $\mathrm{pH}$ & $\mathrm{N}$ & 0.219 & 0.0025 & & \\
\hline & Sodium & $\mathrm{N}$ & 0.938 & 0.0020 & & \\
\hline & Zinc & $\mathrm{B}$ & 19.108 & 0.0056 & & \\
\hline \multirow[t]{5}{*}{ Radon } & Temperature & $\mathrm{N}$ & 0.823 & 0.0015 & 0.813 & 0.4555 \\
\hline & Specific conductance & $\mathrm{N}$ & 0.999 & 0.0789 & & \\
\hline & Silica & $\mathrm{N}$ & 0.825 & 0.0419 & & \\
\hline & Iron & $\mathrm{B}$ & 5.048 & 0.0116 & & \\
\hline & Selenium & $\mathrm{B}$ & 9.544 & 0.0051 & & \\
\hline
\end{tabular}


Appendix 5. Summaries of logistic regression analyses of selected trace elements by major aquifer group.-Continued

[Dependent variable, binary ( 0 for non-occurrence, 1 for occurrence, above reporting level); EXP(B), exponentiated model coefficient (equivalent to odds ratio, $>1$ means direct relation and $<1$ means inverse relation); $c$ statistic is a measure of model discrimination (area under the receiver operating characteristics curve); Hosmer-Lemeshow ${ }^{1}$ statistic is a measure of model fit; N, continuous; B, binary; <, less than; --, not analyzed]

\begin{tabular}{|c|c|c|c|c|c|c|}
\hline $\begin{array}{c}\text { Dependent } \\
\text { variable }\end{array}$ & Explanatory variable & $\begin{array}{c}\text { Type of } \\
\text { variable }\end{array}$ & $\operatorname{EXP}(B)$ & $p$-value & $\begin{array}{c}c \text { statistic } \\
\text { (model discrimination) }\end{array}$ & $\begin{array}{c}\text { Hosmer- } \\
\text { Lemeshow statistic }\end{array}$ \\
\hline \multicolumn{7}{|c|}{ Sandstone and carbonate-rock aquifers-Continued } \\
\hline \multirow[t]{3}{*}{ Selenium } & Dissolved oxygen & $\mathrm{N}$ & 1.525 & 0.0012 & 0.837 & 0.3103 \\
\hline & Arsenic & $\mathrm{B}$ & 4.285 & 0.0519 & & \\
\hline & Uranium & $\mathrm{B}$ & 65.706 & $<0.0001$ & & \\
\hline Strontium & Sulfate & $\mathrm{N}$ & 1.072 & 0.0008 & 0.982 & 0.9075 \\
\hline \multirow[t]{4}{*}{ Uranium } & Molybdenum & $\mathrm{B}$ & 6.734 & 0.0002 & 0.862 & 0.5618 \\
\hline & Selenium & $\mathrm{B}$ & 1.932 & 0.0007 & & \\
\hline & Bicarbonate & $\mathrm{N}$ & 1.007 & 0.0248 & & \\
\hline & Calcium & $\mathrm{N}$ & 1.007 & 0.0159 & & \\
\hline \multicolumn{7}{|c|}{ Carbonate-rock aquifers } \\
\hline \multirow[t]{4}{*}{ Aluminum } & Calcium & $\mathrm{N}$ & 1.024 & $<0.0001$ & 0.801 & 0.6415 \\
\hline & Magnesium & $\mathrm{N}$ & 0.914 & $<0.0001$ & & \\
\hline & Sulfate & $\mathrm{N}$ & 0.982 & 0.0693 & & \\
\hline & Copper & $\mathrm{B}$ & 1.873 & 0.0818 & & \\
\hline \multirow[t]{2}{*}{ Arsenic } & Temperature & $\mathrm{N}$ & 1.425 & $<0.0001$ & 0.906 & 0.0615 \\
\hline & Molybdenum & $\mathrm{B}$ & 10.625 & $<0.0001$ & & \\
\hline \multirow[t]{4}{*}{ Iron } & Well depth & $\mathrm{N}$ & 0.981 & 0.0003 & 0.941 & 0.4243 \\
\hline & Arsenic & $\mathrm{B}$ & 5.437 & 0.0329 & & \\
\hline & Copper & $\mathrm{B}$ & 0.027 & $<0.0001$ & & \\
\hline & Molybdenum & $\mathrm{B}$ & 4.295 & 0.0371 & & \\
\hline \multirow[t]{5}{*}{ Manganese } & Sulfate & $\mathrm{N}$ & 1.039 & 0.0210 & 0.922 & 0.2292 \\
\hline & Dissolved oxygen & $\mathrm{N}$ & 0.728 & 0.0004 & & \\
\hline & Barium & $\mathrm{B}$ & 12.365 & 0.0018 & & \\
\hline & Iron & $\mathrm{B}$ & 8.533 & $<0.0001$ & & \\
\hline & Lead & $\mathrm{B}$ & 0.080 & 0.0033 & & \\
\hline \multirow[t]{5}{*}{ Molybdenum } & Nitrate & $\mathrm{B}$ & 0.363 & 0.0720 & 0.877 & 0.0025 \\
\hline & Sulfate & $\mathrm{N}$ & 1.008 & 0.0124 & & \\
\hline & Arsenic & $\mathrm{B}$ & 13.173 & $<0.0001$ & & \\
\hline & Zinc & $\mathrm{B}$ & 4.497 & 0.0209 & & \\
\hline & Radon & B & 8.615 & 0.0001 & & \\
\hline \multirow[t]{5}{*}{ Nickel } & Specific conductance & $\mathrm{N}$ & 1.009 & $<0.0001$ & 0.909 & 0.0012 \\
\hline & Silica & $\mathrm{N}$ & 0.762 & $<0.0001$ & & \\
\hline & Bromide & $\mathrm{B}$ & 0.280 & 0.0141 & & \\
\hline & Nitrate & B & 5.878 & 0.0032 & & \\
\hline & Nitrogen as ammonia & $\mathrm{B}$ & 0.052 & $<0.0001$ & & \\
\hline
\end{tabular}


Appendix 5. Summaries of logistic regression analyses of selected trace elements by major aquifer group.-Continued

[Dependent variable, binary ( 0 for non-occurrence, 1 for occurrence, above reporting level); EXP(B), exponentiated model coefficient (equivalent to odds ratio, $>1$ means direct relation and $<1$ means inverse relation); $c$ statistic is a measure of model discrimination (area under the receiver operating characteristics curve); Hosmer-Lemeshow ${ }^{1}$ statistic is a measure of model fit; N, continuous; B, binary; <, less than; --, not analyzed]

\begin{tabular}{|c|c|c|c|c|c|c|}
\hline $\begin{array}{l}\text { Dependent } \\
\text { variable }\end{array}$ & Explanatory variable & $\begin{array}{c}\text { Type of } \\
\text { variable }\end{array}$ & $\operatorname{EXP}(B)$ & $p$-value & $\begin{array}{c}c \text { statistic } \\
\text { (model discrimination) }\end{array}$ & $\begin{array}{c}\text { Hosmer- } \\
\text { Lemeshow statistic }\end{array}$ \\
\hline \multicolumn{7}{|c|}{ Carbonate-rock aquifers-Continued } \\
\hline \multirow[t]{3}{*}{ Radon } & $\mathrm{pH}$ & $\mathrm{N}$ & 0.168 & 0.0002 & 0.802 & 0.1311 \\
\hline & Sulfate & $\mathrm{N}$ & 0.979 & 0.0445 & & \\
\hline & Molybdenum & $\mathrm{B}$ & 9.741 & $<0.0001$ & & \\
\hline \multirow[t]{2}{*}{ Strontium } & $\mathrm{pH}$ & $\mathrm{N}$ & 0.110 & 0.0145 & 0.884 & 0.0549 \\
\hline & Dissolved oxygen & $\mathrm{N}$ & 0.718 & $<0.0001$ & & \\
\hline Selenium & -- & & & & & \\
\hline \multirow[t]{5}{*}{ Uranium } & Potassium & $\mathrm{N}$ & 1.208 & 0.0041 & 0.854 & 0.2260 \\
\hline & Dissolved oxygen & $\mathrm{N}$ & 0.814 & 0.0530 & & \\
\hline & Phosphate & $\mathrm{B}$ & 0.141 & 0.0018 & & \\
\hline & Arsenic & $\mathrm{B}$ & 7.540 & 0.0002 & & \\
\hline & Nickel & $\mathrm{B}$ & 6.623 & 0.0007 & & \\
\hline \multicolumn{7}{|c|}{ Basaltic- and other volcanic-rock aquifers } \\
\hline \multirow[t]{2}{*}{ Aluminum } & $\mathrm{pH}$ & $\mathrm{N}$ & 0.015 & 0.0557 & 0.863 & 0.3956 \\
\hline & Dissolved oxygen & $\mathrm{N}$ & 58.869 & 0.0072 & & \\
\hline \multirow[t]{3}{*}{ Arsenic } & Radon & B & 67.655 & 0.0112 & 0.986 & 0.6350 \\
\hline & Sulfate & $\mathrm{N}$ & 1.218 & 0.0313 & & \\
\hline & $\mathrm{pH}$ & $\mathrm{N}$ & 168.835 & 0.0123 & & \\
\hline \multirow[t]{2}{*}{ Boron } & Total dissolved solids & $\mathrm{N}$ & 0.895 & 0.0288 & 0.957 & 0.9358 \\
\hline & Sulfate & $\mathrm{N}$ & 6.917 & 0.0266 & & \\
\hline \multirow[t]{2}{*}{ Iron } & $\mathrm{pH}$ & $\mathrm{N}$ & 0.074 & 0.0116 & 0.930 & 0.9393 \\
\hline & Dissolved oxygen & $\mathrm{N}$ & 0.479 & 0.0003 & & \\
\hline Manganese & Dissolved oxygen & $\mathrm{N}$ & 0.513 & $<0.0001$ & 0.906 & 0.4485 \\
\hline Molybdenum & -- & & & & & \\
\hline Nickel & -- & & & & & \\
\hline Radon & Dissolved oxygen & $\mathrm{N}$ & 0.615 & $<0.0001$ & 0.823 & 0.0109 \\
\hline \multirow[t]{2}{*}{ Selenium } & Sulfate & $\mathrm{N}$ & 1.076 & 0.0006 & 0.901 & 0.0198 \\
\hline & $\mathrm{pH}$ & $\mathrm{N}$ & 0.044 & 0.0042 & & \\
\hline
\end{tabular}

Strontium

Uranium 
Appendix 5. Summaries of logistic regression analyses of selected trace elements by major aquifer group.-Continued

[Dependent variable, binary ( 0 for non-occurrence, 1 for occurrence, above reporting level); EXP(B), exponentiated model coefficient (equivalent to odds ratio, $>1$ means direct relation and $<1$ means inverse relation); $c$ statistic is a measure of model discrimination (area under the receiver operating characteristics curve); Hosmer-Lemeshow ${ }^{1}$ statistic is a measure of model fit; N, continuous; B, binary; <, less than; --, not analyzed]

\begin{tabular}{|c|c|c|c|c|c|c|}
\hline $\begin{array}{c}\text { Dependent } \\
\text { variable }\end{array}$ & Explanatory variable & $\begin{array}{c}\text { Type of } \\
\text { variable }\end{array}$ & $\operatorname{EXP}(B)$ & $p$-value & $\begin{array}{c}c \text { statistic } \\
\text { (model discrimination) }\end{array}$ & $\begin{array}{c}\text { Hosmer- } \\
\text { Lemeshow statistic }\end{array}$ \\
\hline \multicolumn{7}{|c|}{ Crystalline-rock aquifers } \\
\hline \multirow[t]{4}{*}{ Aluminum } & $\mathrm{pH}$ & $\mathrm{N}$ & 0.467 & 0.0009 & 0.792 & 0.6110 \\
\hline & Silica & $\mathrm{N}$ & 0.888 & $<0.0001$ & & \\
\hline & Chromium & $\mathrm{B}$ & 3.495 & 0.0022 & & \\
\hline & Temperature & $\mathrm{N}$ & 1.161 & 0.0185 & & \\
\hline \multirow[t]{4}{*}{ Arsenic } & Barium & $\mathrm{N}$ & 0.117 & 0.0082 & 0.821 & 0.3963 \\
\hline & Nickel & $\mathrm{B}$ & 2.961 & 0.0244 & & \\
\hline & $\mathrm{pH}$ & $\mathrm{N}$ & 1.962 & 0.0055 & & \\
\hline & Dissolved oxygen & $\mathrm{N}$ & 0.720 & 0.0031 & & \\
\hline \multirow[t]{5}{*}{ Copper } & $\mathrm{pH}$ & $\mathrm{N}$ & 0.342 & 0.0004 & 0.910 & 0.4821 \\
\hline & Dissolved oxygen & $\mathrm{N}$ & 1.302 & 0.0035 & & \\
\hline & Iron & $\mathrm{B}$ & 0.210 & 0.0027 & & \\
\hline & Nickel & $\mathrm{B}$ & 6.361 & 0.0006 & & \\
\hline & Zinc & $\mathrm{B}$ & 3.188 & 0.0342 & & \\
\hline \multirow[t]{5}{*}{ Iron } & Dissolved oxygen & $\mathrm{N}$ & 0.650 & 0.0015 & 0.914 & 0.8912 \\
\hline & Nitrate & $\mathrm{B}$ & 0.061 & 0.0210 & & \\
\hline & Uranium & $\mathrm{B}$ & 0.199 & 0.0178 & & \\
\hline & Manganese & $\mathrm{B}$ & 1.005 & 0.0035 & & \\
\hline & Well depth & $\mathrm{N}$ & 0.995 & 0.0121 & & \\
\hline \multirow[t]{5}{*}{ Manganese } & Dissolved oxygen & $\mathrm{N}$ & 0.608 & 0.0010 & 0.916 & 0.6589 \\
\hline & $\mathrm{pH}$ & $\mathrm{N}$ & 0.209 & 0.0001 & & \\
\hline & Iron & $\mathrm{B}$ & 11.674 & $<0.0001$ & & \\
\hline & Zinc & B & 0.240 & 0.0414 & & \\
\hline & Aluminum & $\mathrm{B}$ & 0.181 & 0.0121 & & \\
\hline \multirow[t]{4}{*}{ Molybdenum } & $\mathrm{pH}$ & $\mathrm{N}$ & 4.058 & $<0.0001$ & 0.928 & 0.4879 \\
\hline & Fluoride & $\mathrm{B}$ & 10.007 & $<0.0001$ & & \\
\hline & Iron & $\mathrm{B}$ & 0.354 & 0.0573 & & \\
\hline & Uranium & $\mathrm{B}$ & 3.447 & 0.0094 & & \\
\hline \multirow[t]{6}{*}{ Nickel } & $\mathrm{pH}$ & $\mathrm{N}$ & 0.901 & 0.0691 & 0.878 & 0.1475 \\
\hline & Magnesium & $\mathrm{N}$ & 0.636 & $<0.0001$ & & \\
\hline & Potassium & $\mathrm{N}$ & 1.189 & 0.0039 & & \\
\hline & Silica & $\mathrm{N}$ & 0.911 & 0.0004 & & \\
\hline & Bromide & $\mathrm{B}$ & 5.575 & 0.0014 & & \\
\hline & Copper & $\mathrm{B}$ & 10.189 & 0.0005 & & \\
\hline \multirow[t]{5}{*}{ Lead } & Temperature & $\mathrm{N}$ & 1.163 & 0.0086 & 0.794 & 0.0345 \\
\hline & Molybdenum & $\mathrm{B}$ & 0.142 & 0.0030 & & \\
\hline & Uranium & $\mathrm{B}$ & 6.350 & 0.0050 & & \\
\hline & Radon & $\mathrm{B}$ & 3.802 & 0.0077 & & \\
\hline & Dissolved oxygen & $\mathrm{N}$ & 1.230 & 0.0140 & & \\
\hline
\end{tabular}


Appendix 5. Summaries of logistic regression analyses of selected trace elements by major aquifer group.—Continued

[Dependent variable, binary ( 0 for non-occurrence, 1 for occurrence, above reporting level); EXP(B), exponentiated model coefficient (equivalent to odds ratio, $>1$ means direct relation and $<1$ means inverse relation); $c$ statistic is a measure of model discrimination (area under the receiver operating characteristics curve); Hosmer-Lemeshow ${ }^{1}$ statistic is a measure of model fit; N, continuous; B, binary; <, less than; --, not analyzed]

\begin{tabular}{|c|c|c|c|c|c|c|}
\hline $\begin{array}{l}\text { Dependent } \\
\text { variable }\end{array}$ & Explanatory variable & $\begin{array}{c}\text { Type of } \\
\text { variable }\end{array}$ & $\operatorname{EXP}(B)$ & $p$-value & $\begin{array}{c}c \text { statistic } \\
\text { (model discrimination) }\end{array}$ & $\begin{array}{c}\text { Hosmer- } \\
\text { Lemeshow statistic }\end{array}$ \\
\hline \multicolumn{7}{|c|}{ Crystalline-rock aquifers-Continued } \\
\hline \multirow[t]{5}{*}{ Radon } & Temperature & $\mathrm{N}$ & 0.867 & 0.0292 & 0.832 & 0.6834 \\
\hline & Sulfate & $\mathrm{N}$ & 0.917 & 0.0018 & & \\
\hline & Arsenic & $\mathrm{B}$ & 0.162 & 0.0045 & & \\
\hline & Uranium & $\mathrm{B}$ & 14.724 & $<0.0001$ & & \\
\hline & Lead & B & 2.724 & 0.0438 & & \\
\hline \multirow[t]{2}{*}{ Strontium } & Calcium & $\mathrm{N}$ & 1.099 & 0.0011 & 0.826 & 0.6674 \\
\hline & Molybdenum & B & 8.883 & 0.0180 & & \\
\hline Selenium & -- & & & & & \\
\hline \multirow[t]{6}{*}{ Uranium } & Calcium & $\mathrm{N}$ & 1.080 & $<0.0001$ & 0.923 & 0.3881 \\
\hline & Nitrate & B & 0.266 & 0.313 & & \\
\hline & Fluoride & $\mathrm{B}$ & 4.863 & 0.0073 & & \\
\hline & Iron & $\mathrm{B}$ & 0.153 & 0.0011 & & \\
\hline & Molybdenum & $\mathrm{B}$ & 14.865 & $<0.0001$ & & \\
\hline & Lead & B & 11.696 & 0.0010 & & \\
\hline \multirow[t]{5}{*}{ Zinc } & Temperature & $\mathrm{N}$ & 1.252 & 0.0251 & 0.863 & 0.0209 \\
\hline & $\mathrm{pH}$ & $\mathrm{N}$ & 0.279 & 0.0001 & & \\
\hline & Silica & $\mathrm{B}$ & 0.921 & 0.0129 & & \\
\hline & Copper & B & 3.245 & 0.0126 & & \\
\hline & Cobalt & $\mathrm{B}$ & 0.047 & 0.0326 & & \\
\hline
\end{tabular}

\footnotetext{
${ }^{1}$ Hosmer, D.W., and Lemeshow, S., 2000, Applied logistic regression (2nd ed.): New York, John Wiley and Sons, 375 p.
} 
Prepared by the Pembroke Publishing Service Center.

For more information concerning this report, contact:

Director

U.S. Geological Survey

New Hampshire-Vermont Water Science Center

331 Commerce Way, Suite 2

Pembroke, NH 03275

dc_nh@usgs.gov

or visit our Web site at:

http://nh.water.usgs.gov 
